\title{
A ADOÇÃO DE SISTEMAS DE AVALIAÇÃO AMBIENTAL DE EDIFÍCIOS (LEED E PROCESSO AQUA) NO BRASIL: MOTIVAÇÕES, BENEFÍCIOS E DIFICULDADES
}

\author{
Dissertação apresentada ao Instituto de \\ Arquitetura e Urbanismo da Escola de \\ Engenharia de São Carlos, Universidade de São \\ Paulo, para obtenção do titulo de Mestre em \\ Arquitetura e Urbanismo. \\ Área de concentração: \\ Arquitetura, Urbanismo e Tecnologia \\ Orientador: Prof.Dr. Marcio Minto Fabrício
}

São Carlos

2012

Versão Corrigida 
AUTORIZO A REPRODUÇÃO TOTAL OU PARCIAL DESTE TRABALHO, POR QUALQUER MEIO CONVENCIONAL OU ELETRÔNICO, PARA FINS DE ESTUDO E PESQUISA, DESDE QUE CITADA A FONTE.

Ficha catalográfica preparada pela Seção de Atendimentos ao Usuário do Serviço de Biblioteca - EESC/USP.

Muñoz Barros, Ana Dorys
M967a A Adoção de sistemas de avalização ambiental de edifícios (LEED e Processo AQUA) no Brasil: motivações, benefícios e dificuldades. / Ana Dorys Muñoz Barros; orientador Marcio Minto Fabrício. São Carlos, 2012.

Dissertação (Mestrado) - Programa de Pós-Graduação em Arquitetura e Urbanismo e Área de Concentração em Arquitetura, Urbanismo e Tecnologia -- Instituto de Arquitetura e Urbanismo da Universidade de São Paulo, 2012 .

1. Sistema de avaliação ambiental para edifícios. 2. Motivação para o LEED e processo AQUA. 3. Benefícios para O LEED e processo AQUA. 4. Dificuldades para o LEED e processo AQUA. I. Título. 


\section{FOLHA DE JULGAMENTO}

Candidata: Licenciada Ana Dorys Muñoz Barros

Título da dissertação: "A Adoção de sistemas de avaliação ambiental de edifícios (LEED e Processo AQUA) no Brasil: motivações, benefícios e dificuldades".

Data da defesa: 22/08/2012.

\section{Comissão Julgadora:}

Prof. Associado Márcio Minto Fabricio (orientador) (Instituto de Arquitetura e Urbanismo/USP)

Prof. Titular Francisco Ferreira Cardoso (Escola Politécnica/USP)

Prof. Associado João Adriano Rossignolo (Instituto de Arquitetura e Urbanismo/USP)

\section{Resultado:}
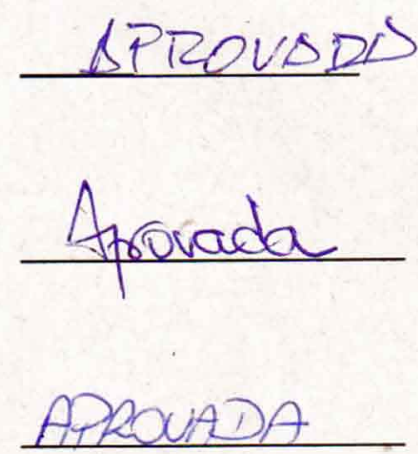

Presidente e Coordenador do Programa de Pós-Graduação em Arquitetura Urbanismo: Professor Titular Renato Luiz Sobral Anelli 


\section{AGRADECIMENTOS}

Meus agradecimentos ao professor Marcio Minto Fabrício, meu orientador, pela ajuda e apoio que permitiu a oportunidade de realizar meus estudos de mestrado na USP.

Grande agradecimento ao prof. Naylor Vilas Boas pela ajuda na correção.

Ao prof. Francisco Cardoso que ofereceu suas opiniões criticas sobre o trabalho.

Ao CNPq, pelo apoio financeiro concedido em forma de bolsa de estudo nesses dois anos de pesquisa.

E finalmente meus maiores agradecimentos vão ao meu pai, minha mãe, e as minhas irmãs, pela compreensão e o incentivo graças aos quais realizei meu mestrado. 
MUÑOZ BARROS, A.D. (2012). A adoção de sistemas de avaliação ambiental de edifícios (LEED e Processo AQUA) no Brasil: Motivações, benefícios e dificuldades. Dissertação (Mestrado) - Escola de Engenharia de São Carlos, Universidade de São Paulo, São Carlos, 2012.

Os sistemas de avaliação ambiental de edifícios são cada vez mais empregados no mercado de construção, servindo de suporte para a realização de diversos estudos acadêmicos sobre esta matéria. Muitos autores e sites ressaltam os benefícios das certificações LEED e do Processo AQUA, porém poucos discutem quantitativamente os efeitos, dificuldades e motivos de sua adoção, evidenciando, dessa forma, a necessidade e a importância de pesquisas como esta. Neste contexto, este trabalho tem como objetivo geral traçar um panorama da certificação ambiental de edifícios no Brasil, através da percepção dos principais intervenientes (stakeholder) no processo. Os objetivos principais deste trabalho consistem na identificação das motivações para a certificação de sistemas de avaliação ambiental de edifícios (LEED e Processo AQUA) e dos benefícios e dificuldades inerentes a sua implementação. Foi possível ainda efetuar várias recomendações destinadas a orientar e facilitar o processo de adoção destes sistemas, que inclui a proposta de ações a serem desenvolvidas pelas empresas, organismos de certificação e autoridades governamentais competentes. O método utilizado foi de pesquisa survey, junto a vários agentes envolvidos no processo de certificação ambiental. Para tal, foram concebidos diferentes questionários destinados a caracterizar a adoção dos sistemas de avaliação ambiental de edifícios que foram encaminhados aos empreendedores e consultores de empreendimentos certificados ou em processo de certificação. Obtiveram-se em total 21 questionários válidos que indicaram que as principais motivações para obter a certificação estão ligadas à melhoria da imagem e do empreendimento e que os principais benefícios estão relacionados com o marketing e a redução dos custos operacionais. Estes resultados também indicaram que existem dificuldades para essa adoção principalmente com a falta de integração no processo de projeto e a falta de fornecedores para materiais e tecnologias sustentáveis.

Palavras-chave: Sistemas de avaliação ambiental de edifícios (LEED e Processo AQUA), motivações, benefícios e dificuldades. 
MUÑOZ BARROS, A.D. (2012). The adoption of environmental assessment systems of buildings (LEED e Process AQUA) in Brazil: Motivations, benefits e difficulties. Dissertação (Mestrado) - Escola de Engenharia de São Carlos, Universidade de São Paulo, São Carlos, 2012.

The building environmental assessment systems over the world are employing increasingly and we can find several studies concerning this subject. Many authors and websites emphasize the benefits of LEED and Process AQUA, but few discuss quantitatively the impacts, difficulties and reasons for its adoption, showing thus the need and importance of research like this. In this context, this paper aims to outline a general overview of the environmental certification of buildings in Brazil, through the key stakeholders perception (stakeholder) of the process. The main targets of this work were to identify the motivations for the environmental assessment systems for buildings and the corresponding benefits and difficulties concerning of implementation. It was also possible to make some recommendations to orientate and support the adoption of environmental assessment systems for buildings. These recomendations include the identification of actions to be implemented by companies, certification bodies and governmental authorities. In order to accomplish the defined targets, it were developed surveys which can lead to characterize the adoption of environmental assessment systems for buildings (LEED and AQUA Process). These survey was sent directly to entrepreneurs and consultants of a sample of brasilian companies with building certified or certification process (LEED and AQUA Process). It was received 21 answers that indicated that the main motivations for certification are linked to improving the image and building and that the main benefits are related to marketing and reducing operating costs. These results also indicated that there are difficulties in adopting this especially with the lack of integration in the design process and the lack of suppliers for materials and sustainable technologies.

Key-words: Building environmental assessment systems (LEED and AQUA Process), motivations, benefits and difficulties. 
Figura 1:Etapas do processo de certificação LEED .12

Figura 2:Fases do processo de certificação AQUA......................................................17

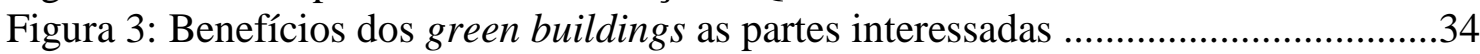

Figura 4: Delineamento das etapas de pesquisa..........................................................53

Figura 5: Frequência de resposta das motivações dos empreendedores para a

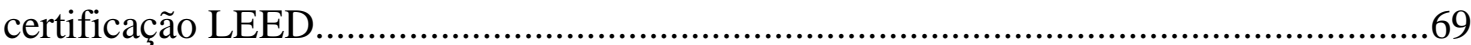

Figura 6: Motivações dos empreendedores para a certificação LEED.............................70

Figura 7: Frequência de respostas dos empreendedores dos benefícios da implementação

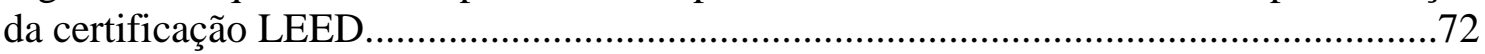

Figura 8: Benefícios dos empreendedores da implementação da certificação LEED.....72

Figura 9: Frequência de respostas das dificuldades dos empreendedores para a implementação da certificação LEED...................................................................... 74

Figura 10: Dificuldades dos empreendedores para a implementação da certificação

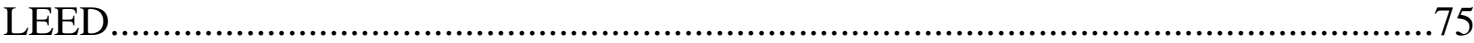

Figura 11: Frequência de respostas dos empreendedores das etapas do empreendimento

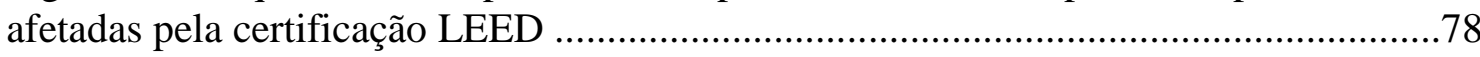

Figura 12: Etapas do empreendimento afetadas positivamente pela certificação LEED

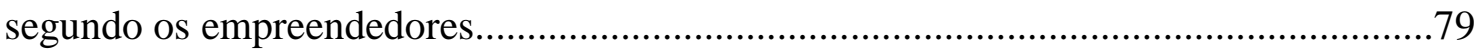

Figura 13: Frequência de respostas dos empreendedores das dificuldades em atingir as

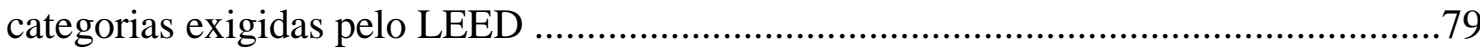

Figura 14:Dificuldades dos empreendedores em atingir as categorias exigidas pelo

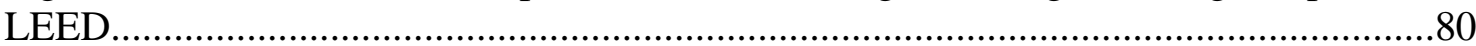

Figura 15: Frequência de resposta das motivações dos empreendedores para o Processo

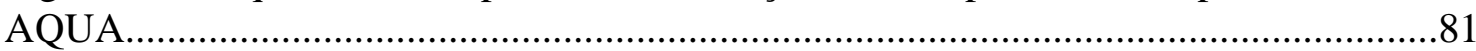

Figura 16: Motivações dos empreendedores para o Processo AQUA............................82

Figura 17: Frequência de resposta dos benefícios da implementação do Processo AQUA

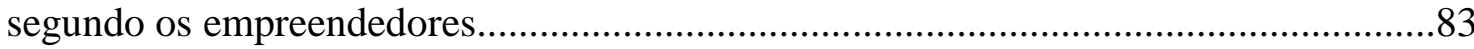

Figura 18: Benefícios da implementação do Processo AQUA segundo os

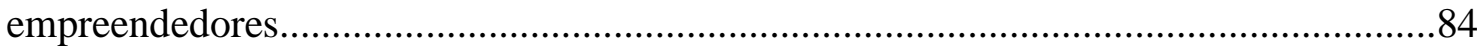

Figura 19: Frequência de resposta das dificuldades dos empreendedores da

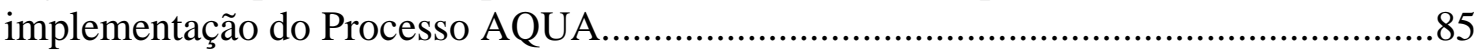

Figura 20: Dificuldades da implementação do Processo AQUA segundo os

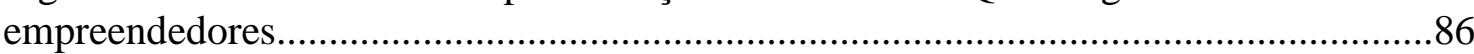

Figura 21: Frequência de respostas das dificuldades dos empreendedores em atingir as

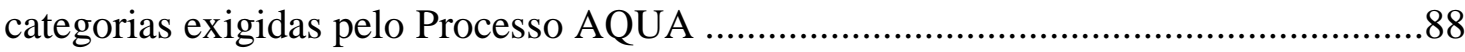

Figura 22: Dificuldades dos empreendedores em atingir as categorias exigidas pelo

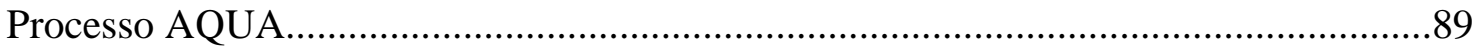
Figura 23: Frequência de resposta das motivações dos consultores para a certificação

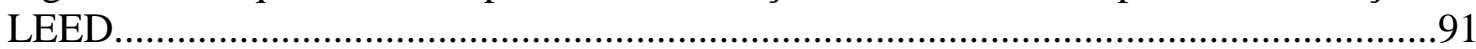

Figura 24: Motivações dos consultores para a certificação LEED................................91 Figura 25: Frequência de resposta dos consultores dos benefícios da implementação da

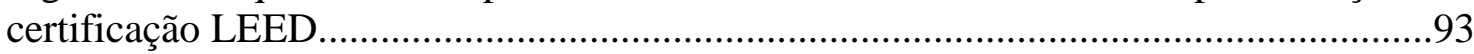

Figura 26: Benefícios da implementação da certificação LEED segundo os

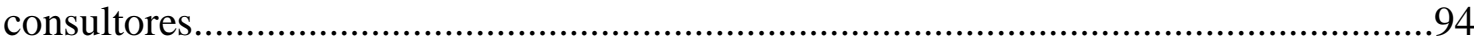

Figura 27: Frequência de respostas das dificuldades da implementação da certificação

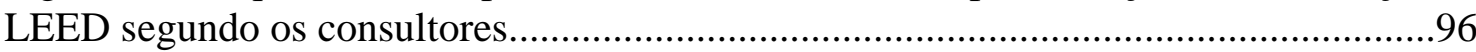


Figura 28: Dificuldades da implementação da certificação LEED segundo os consultores

Figura 29: Frequência de respostas dos consultores relacionadas às etapas do empreendimento afetadas pela certificação LEED.

Figura 30: Frequência das respostas dos consultores das categorias relevantes da certificação LEED..

Figura 31: Categorias mais difíceis de alcançar da certificação LEED segundo os consultores.....

Figura 32: Categorias da certificação LEED que geram atraso na obra segundo os consultores...... 
Tabela 1: Número de empreendimentos certificados e em processo de certificação......57

Tabela 2: Empresas proprietárias e empreendimentos certificados LEED.....................58

Tabela 3: Empresas proprietárias com empreendimentos em processo de certificação LEED até 01/03/2012

Tabela 4: Composição do universo de pesquisa junto às empresas proprietárias

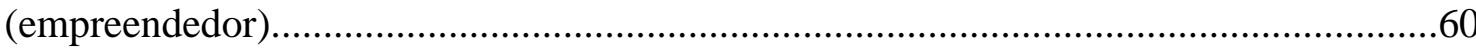

Tabela 5: Empresas proprietárias e empreendimentos certificados LEED.....................61

Tabela 6: Empresas proprietárias e empreendimentos em processo de certificação

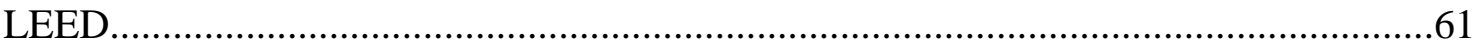

Tabela 7: Composição do universo de pesquisa junto às empresa de consultoria...........61 Tabela 8: Empresas proprietárias e empreendimentos certificados pelo Processo AQUA .62

Tabela 9: Empresas proprietárias e empreendimentos com processos iniciados pelo Processo AQUA

Tabela 10: Estadísticas preliminares referentes aos grupos de empresas a serem estudados .63

Tabela 11: Definição da população da pesquisa da pesquisa da base de dados..............64 Tabela 12: Definição da população da pesquisa da base de dados envolvendo proprietários ou responsáveis até março de 2012.

Tabela 13: Definição da população da pesquisa da base de dados envolvendo consultores até março de 2012 .65

Tabela 14: Taxa de retorno da pesquisa. .66 


\section{LISTA DE QUADROS}

Quadro 1: Principais motivações para a adoção dos sistemas de avaliação ambiental de edifícios. 22

Quadro 2: Principais benefícios dos edifícios sustentáveis...........................................33

Quadro 3: Principais benefícios dos edifícios certificados pelo Processo AQUA...........38

Quadro 4: Principais dificuldades encontradas pelas empresas..................................42

Quadro 5: Possíveis fatores que influem no custo inicial devido à certificação..............51

Quadro 6: Percepção do custo adicional pelos empreendedores da certificação

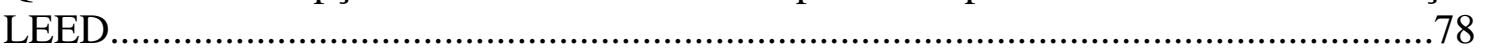

Quadro 7: Percepção do custo adicional pelos consultores da certificação

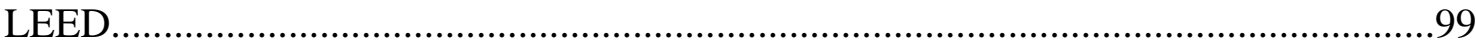

Quadro 8:Principais motivações, benefícios e dificuldades da implementação do

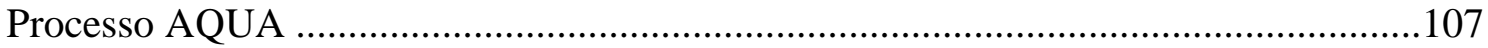

Quadro 9:Principais motivações, benefícios e dificuldades da implementação da certificação LEED. 108 


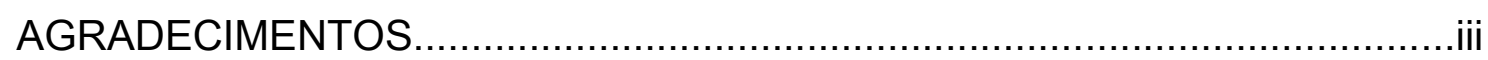

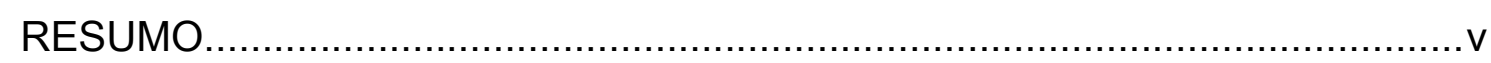

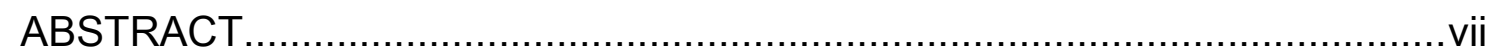

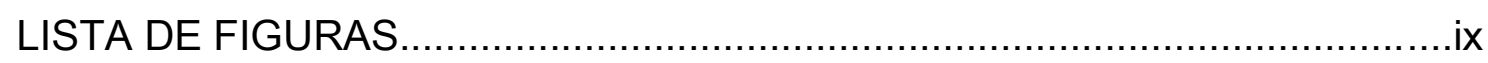

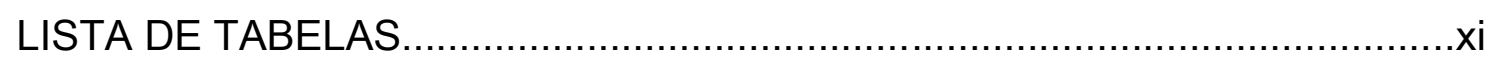

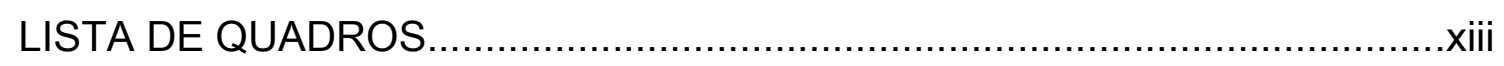

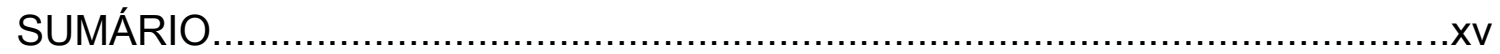

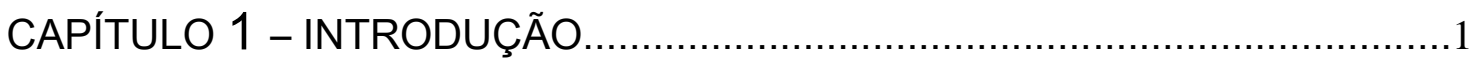

1.1 - Contextualização e justificativas da pesquisa.......................................................

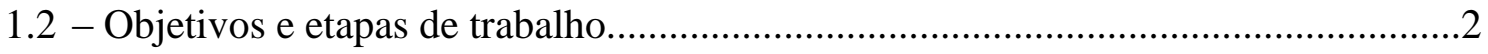

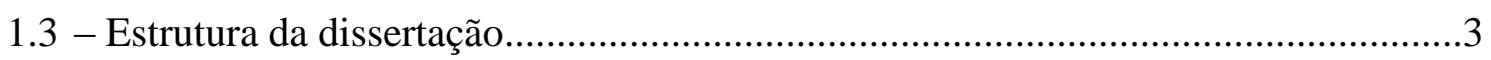

CAPÍTULO 2 - MOTIVAÇÕES, BENEFÍCIOS E DIFICULDADES DA ADOÇÃO DE SISTEMAS DE AVALIAÇÃO AMBIENTAL DE EDIFÍCIOS..4

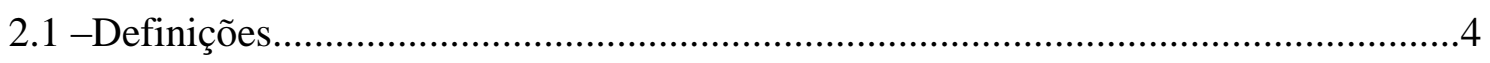

2.2 - Sistemas de avaliação ambiental de edifícios....................................................

2.2.1 - Certificação LEED............................................................................... 9

2.2.2 - Processo AQUA..................................................................................13

2.3 - As motivações, benefícios e dificuldades da adoção de sistemas de avaliação ambiental de edifícios.............................................................................19

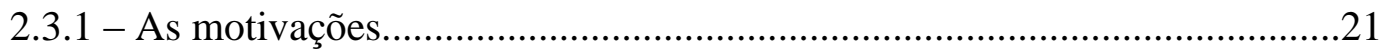

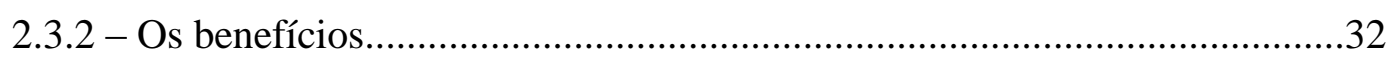

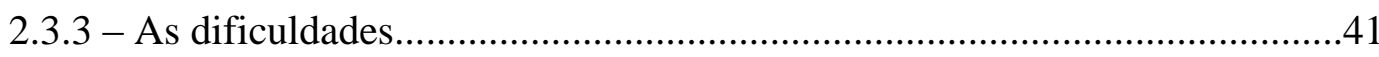

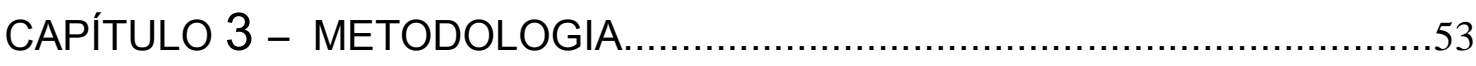

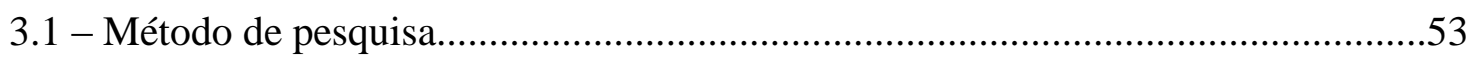

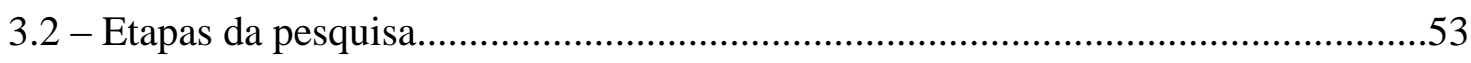

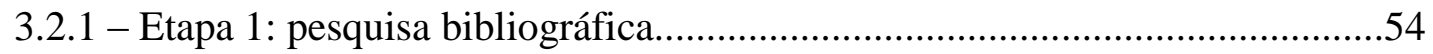

3.2.2 - Etapa 2: Levantamento tipo survey.........................................................54

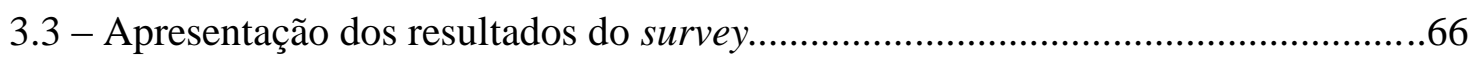

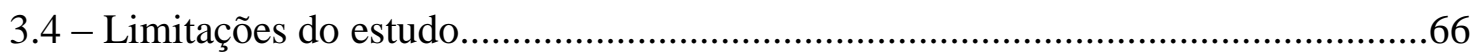

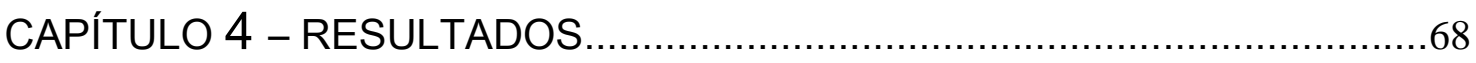

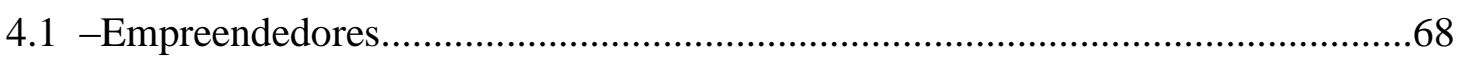

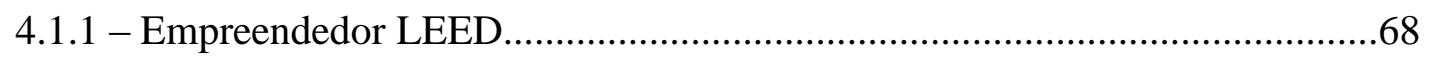




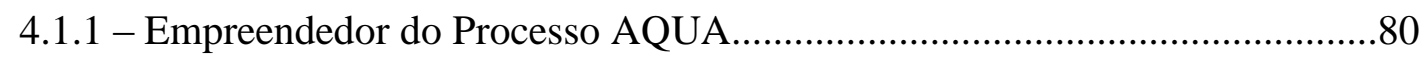

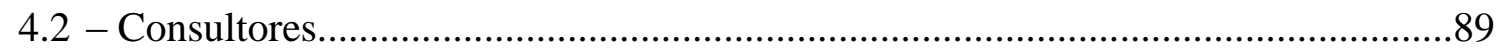

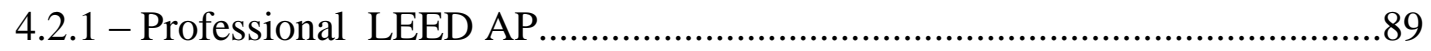

4.2.1 - Consultores do Processo AQUA.................................................................103

CAPÍTULO 5 - CONCLUSÕES E RECOMENDAÇÕES.................................107

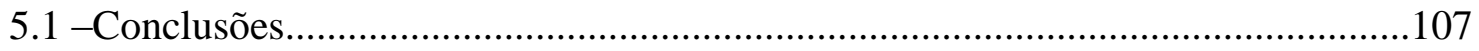

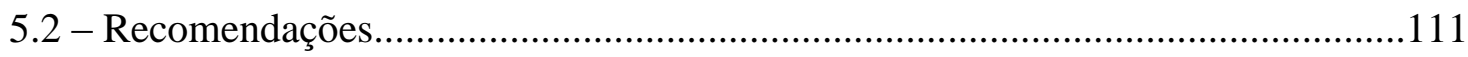

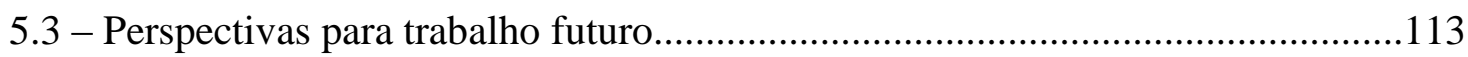

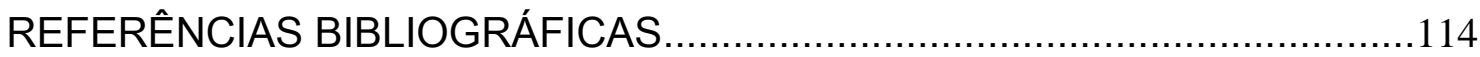

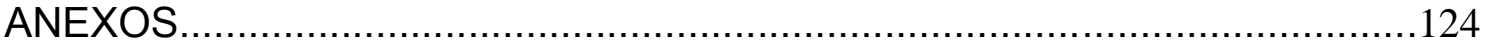

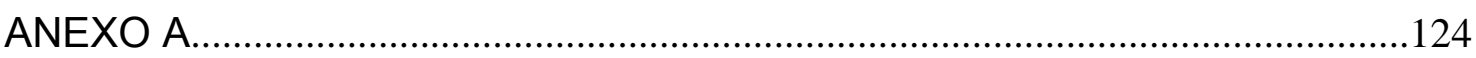

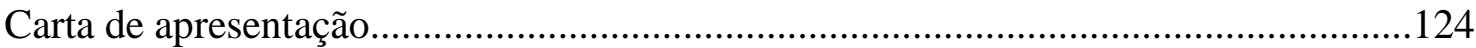

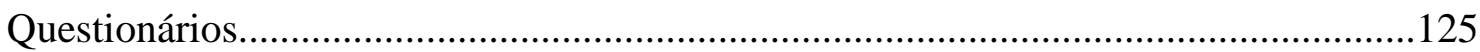

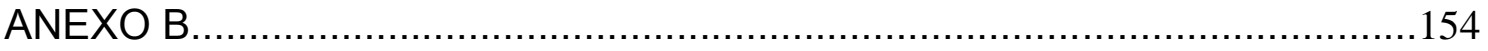

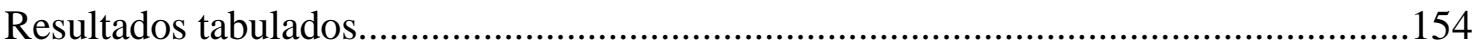




\section{CAPÍTULO 1}

\section{INTRODUÇÃO}

\subsection{CONTEXTUALIZAÇÃO E JUSTIFICATIVA DA PESQUISA}

Construção sustentável e green building são termos bastante discutidos atualmente, nas mais diversas especialidades, com a preocupação cada vez maior com as questões do desenvolvimento sustentável. As mudanças em direção ao desenvolvimento sustentável devem envolver pessoas, entidades, empresas e governos. Iniciativas que têm sido observadas por estas organizações envolvem: pesquisas e produção de informações, seja desenvolvendo produtos, certificando as construções sustentáveis ou agregando valor econômico ao espaço construído.

Com a percepção que desenvolvimento econômico e ambiental estão interligados, engenheiros, arquitetos, investidores e construtores são orientados a garantir a ausência de impactos negativos ao meio ambiente e à sociedade através da adoção de práticas de desenvolvimento sustentável durante o projeto e a construção do edifício. No entanto, observa-se que os profissionais são muitas vezes impedidos de atuar de forma proativa na adoção de princípios de green building no desenvolvimento e implantação do edifício devido à falta de dados históricos, de procedimentos padronizados e técnicas para determinar os impactos do projeto (DASILVA, 2008).

Os modelos para certificação ambiental de edifícios se apresentam como uma importante ferramenta de avaliação de desempenho ambiental de edifícios. Muitas partes interessadas (stakeholders) da indústria da construção empregam este processo de certificação para estabelecer critérios e validar um edifício sustentável (JOHNSON, 2005). Estes modelos estabelecem os requisitos para obter a certificação, sem definir a forma como os requisitos devem ser alcançados, permitindo, portanto, que as empresas desenvolvam suas próprias soluções para o atendimento das exigências da certificação.

O processo de adoção da certificação constitui uma mudança na forma em que a construção é executada, afetando os métodos e materiais utilizados como também o processo no qual são construídos os edifícios, desde o planejamento até a certificação (JOHNSON, 2005). Devido a isso, as empresas passam por uma série de dificuldades 
durante o processo de adoção do sistema de avaliação ambiental de edifícios e operacionalização do edifício.

O estudo da aplicabilidade do LEED e do Processo AQUA no contexto brasileiro é necessário, uma vez que essas certificações são as mais aceitas comercialmente em âmbito nacional e norteiam as edificações interessadas em certificação ambiental. Muitos autores e sites ressaltam os benefícios das certificações LEED e do Processo AQUA, porém poucos discutem quantitativamente os efeitos, dificuldades e motivos de sua adoção, evidenciando, dessa forma, a necessidade e a importância de pesquisas como esta.

\subsection{OBJETIVOS E ETAPAS DE TRABALHO}

O objetivo desta pesquisa é traçar um panorama da certificação ambiental de edifícios no Brasil, através da percepção dos principais intervenientes (stakeholder) no processo. Para isso, buscou-se os seguintes objetivos:

$>$ Identificar as motivações para a certificação ambiental de edifícios (LEED e Processo AQUA);

$>$ Identificar os benefícios e as dificuldades para a certificação ambiental de edifícios (LEED e Processo AQUA);

$>$ Efetuar um conjunto de recomendações destinadas a orientar e facilitar o processo de adoção de sistemas de avaliação ambiental de edifícios (LEED e Processo AQUA).

Para desenvolver os objetivos o trabalho contou com as seguintes etapas de investigação:

$>$ Levantamento e análise da bibliografia relacionada aos assuntos estudados no trabalho;

$>$ Levantamento preliminar dos empreendimentos certificados e dos que estão ainda em processo de certificação pelos sistemas de avaliação ambiental de edifícios LEED e Processo AQUA;

$>$ Levantamento das empresas incorporadoras, consultores, profissionais credenciados dos empreendimentos sustentáveis; 
$>$ Realizar entrevistas via survey através de questionários estruturados para identificar as motivações, benefícios e dificuldades relacionados ao processo de certificação LEED e do Processo AQUA;

$>$ Escrita dos resultados obtidos dos questionários aplicados aos empreendedores, consultores, profissionais credenciados pelo LEED;

$>$ Discussão crítica dos tópicos levantados pela teoria e os resultados obtidos dos questionários;

$>$ Proposição de recomendações e perspectivas para trabalhos futuros.

\subsection{ESTRUTURA DA DISSERTAÇÃO}

A dissertação está estruturada em 5 capítulos. No primeiro capítulo efetua-se uma breve contextualização e justificativa da pesquisa e são apresentados os seus objetivos e a estrutura da dissertação. Segue-se o Capítulo 2 em que são apresentadas algumas definições da sustentabilidade na construção e uma visão sobre os sistemas de avaliação ambiental de edifícios, mais especificamente da certificação LEED e do Processo AQUA. Este Capítulo também apresenta o estado da arte das motivações, benefícios e dificuldades da adoção de sistemas de avaliação ambiental de edifícios como resultado da pesquisa bibliográfica efetuada. Os Capítulos 3 e 4 apresentam, respectivamente, a descrição da metodologia adotada e os resultados obtidos, que são discutidos em ligação com o resultado da investigação efetuada. No Capítulo 5 são apresentadas as conclusões gerais e especificas sobre a pesquisa e indicam-se um conjunto de recomendações para trabalhos futuros. No final encontram-se as referencias bibliográficas e os anexos que contém os questionários e os resultados tabulados dos questionários. 


\section{MOTIVAÇÕES, BENEFÍCIOS E DIFICULDADES DA ADOÇÃO DE SISTEMAS DE AVALIAÇÃO AMBIENTAL DE EDIFÍCIOS}

\subsection{DEFINIÇÕES}

A Comissão de Brundtland define ao desenvolvimento sustentável como "o desenvolvimento que atende as necessidades presentes sem comprometer a habilidade das gerações futuras de atender suas próprias necessidades" (BRUNDTLAND, 1987). Este conceito esta apoiado em três dimensões a dimensão social, pedindo uma sociedade mais justa, que proporcione oportunidades de desenvolvimento humano e um nível aceitável de qualidade de vida; a dimensão ambiental, solicitando equilíbrio entre a proteção do ambiente físico e o consumo dos recursos naturais e a dimensão econômica, requerendo de um sistema econômico que facilite o acesso aos recursos e oportunidades sem ferir os limites ecológicos e os diretos humanos (CIB/UNEP-IETC, 2002).

Muito se tem veiculado na mídia edificações sustentáveis, construções sustentáveis e green buildings, nomes dados ao mesmo produto porém com semânticas diferentes (PARDINI, 2009). Define-se construção sustentável como o atendimento dos princípios do desenvolvimento sustentável a todo ciclo de construção, desde a extração e beneficiamento das matérias primas, percorrendo as fases de planejamento, projeto e execução do edifício, até a sua desconstrução final e gerenciamento dos resíduos resultantes (A21-CSPD, 2002). De forma análoga, edifício sustentável ou "green building" podem ser definidos como edifícios que buscam desde o seu projeto, um balanço entre fatores econômicos e compromissos com o ambiente e a sociedade devendo englobar todas as iniciativas dedicadas à criação de construções que utilizem recursos de maneira eficiente; que sejam confortáveis; e que tenham vida útil ampliada, adaptando-se às mudanças nas necessidades dos usuários e permitindo desmontagem ao final do ciclo de vida do edifício, para aumentar a vida útil dos componentes através de sua reutilização ou reciclagem (SILVA, 2007).

A ideia de green building não é recente, suas raízes datam de mais de trinta anos, quando surgiu um movimento disperso de ambientalistas em torno ao assunto (CRYER et al., 2006). Até a década de 70, as necessidades dos edifícios eram controladas do lado do 
fornecimento, quanto mais se necessitava mais se produzia. A crise do petróleo nos anos 70, fez com que os projetistas voltassem suas atenções para a eficiência energética de edifícios. Consequentemente, começou-se a tentar resolver as necessidades dos edifícios no lado do consumo (SUSTENTARE, 2009 e LUCUIK et al., 2005).

Ainda na década de 70, o mercado da reciclagem desenvolve-se nos EUA e começa a captar as atenções da indústria da construção. Na década de 80 , surge a alerta para a "Síndrome dos edifícios doentes" que trouxe novas preocupações acerca da saúde, conforto e produtividade dos trabalhadores e ocupantes dos edifícios. Nesse período, começam os esforços para reduzir as emissões toxicas dos materiais de construção e de acabamentos dos edifícios (SUSTENTARE, 2009 e LUCUIK et al., 2005).

A água como bem escasso se tornou uma preocupação no desenvolvimento de projetos em locais onde há escassez de água. Até então a preocupação com a sustentabilidade era focada numa questão exclusivamente: energia, reciclagem de materiais ou conservação da água. Entre os anos 80 e 90 surgiram os primeiros escritórios de arquitetura onde se começaram a integrar todos os fatores de impacto de um edifício no meio ambiente, criando o conceito de edifício sustentável ou "green building" (SUSTENTARE, 2009 e LUCUIK et al., 2005). Nestes últimos anos tem surgido a preocupação por minimizar os custos da construção e operação. Lucuik et al. (2005) acreditam que enquanto esse conjunto de fatores continue se transformando a definição de green building será subjetiva, sem um entendimento universal para comparação de atributos sustentáveis.

Os seis princípios básicos para a conceituação de um green building, segundo Johnson (2005), são a escolha adequada do local, a localização, orientação e paisagismo que afetam os ecosistemas locais, métodos de transporte e uso de energia. O segundo princípio é reduzir o consumo de energia, para atender ou exceder o nível de desempenho e eficiência energética que se pretende para o edifício e para os seus sistemas e equipamentos, para o qual no edifício, devem-se substituir fontes de energia convencionais por fontes renováveis e/ou alternativas. O terceiro princípio seria reduzir o consumo da água controlando reduzir e tratar as águas residuais e utilizar eficiente e parcimoniosamente a água, reusando e reciclando-a quando possível. O quarto princípio é utilizar produtos com menor impacto ambiental utilizando materiais com menores impactos ambientais, prevendo a redução da quantidade de materiais necessários durante a 
construção do edifício e gestionando a redução dos resíduos produzidos durante o processo de construção e operação do edifício. O quinto princípio é a qualidade do ambiente interior que tem um impacto significativo na saúde, conforto e produtividade de seus ocupantes. Entre outros atributos, um edifício sustentável deve maximizar o uso da luz natural, dispor de uma adequada ventilação e controle da umidade, evitar o uso de materiais com emissão de compostos voláteis e fornecer ligações ao ambiente exterior a todos os ocupantes do edifício. O sexto princípio seria a operação e manutenção, pois um edifício sustentável deve ser projetado tomando em consideração os impactos ambientais e energéticos da operação e manutenção do edifício. Os projetistas são encorajados a especificar materiais e sistemas que simplificam e reduzem os requisitos de manutenção, consomem menos água, energia e materiais de limpeza menos tóxicos e em menores quantidades e apresentam uma boa relação custo beneficio e baixos impactos em seu ciclo de vida.

O objetivo primordial da procura de práticas de uma construção sustentável é diminuir os seus impactos através da criação de green building, envolvendo diferentes preocupações em todo o ciclo de vida do edifício. Para The European Commision et al., (2001), a escolha das questões (preocupações) é arbitraria, variando de um green building a outro, como reflexos do clima, da localização do projeto, do tamanho do edifício, de sua complexidade e da utilização do edifício, com os quais variam as necessidades de aquecimento, de arrefecimento, de ventilação ou de luz natural.

Kibert (2007) considera que os green buildings são necessários para orientar aos membros da equipe às metas e objetivos do projeto que estão relacionadas com questões como uso eficiente dos recursos, sustentabilidade, certificação, por citar algumas. Segundo este autor, esta orientação pode servir para três propósitos:

$>$ ela pode informar à equipe acerca das questões do projeto;

$>$ esta pode familiarizar à equipe de projeto com os aspectos prioritários do proprietário relacionados ao projeto green building;

$>$ esta pode proporcionar a oportunidade de realizar um trabalho em equipe, através da formação dos grupos de exercícios, para poder familiarizar ao grupo com o edifício o programa base e com as questões referentes à construção de green building. 
É importante ressaltar que, desde a fase de planejamento do projeto, os green buildings não acontecem por acaso nem através da ação isolada dos diferentes intervenientes no processo (KIBERT, 2007). Tradicionalmente, durante as primeiras etapas do projeto, as soluções são desenvolvidas apenas pelo escritório de arquitetura e validadas pelo cliente e, depois do caso básico concebido, inicia-se a contratação dos demais projetistas e o desenvolvimento dos demais projetos (FIGUEIREDO et al., 2010). Pelo contrário os green buildings, requerem a comunicação e a colaboração de vários profissionais (incorporador, principais fornecedores, projetistas, construtora e consultores) ligados ao setor e uma abordagem integrada de forma a garantir que o desempenho e o custo final do edifício (e ao longo do seu ciclo de vida) atingem todos os objetivos propostos no inicio do processo de projeto (KIBERT, 2007).

\subsection{SISTEMAS DE AVALIAÇÃO AMBIENTAL DE EDIFÍCIOS}

A primeira iniciativa da necessidade de se avaliar o desempenho ambiental de edifícios veio com a constatação de que, mesmo os países que acreditavam dominar os conceitos de projeto ecológico, não possuíam meios para verificar o quão "verdes" eram de fato os seus edifícios. A segunda iniciativa surgiu com o acordo entre pesquisadores e agências governamentais quanto à classificação de desempenho atrelada aos sistemas de certificação ser um dos métodos mais eficientes para elevar o nível de desempenho ambiental do estoque construído e de novas edificações (SILVA, 2007).

No inicio da década de 1990, no Reino Unido, foi desenvolvido o primeiro sistema de avaliação ambiental de edifícios, o BREEAM, que serviu de base para outros orientados para o mercado, como o Leadership in Energy and Environmental Design - LEED (Estados Unidos), Hong Kong Building Environmental Assessment Method- HK-BEAM (Hong Kong) e o Comprehensive Assessment System for Building Environmental Efficiency - CASBEE (Japão), entre outros. Quase todos os países europeus, Estados Unidos, Canadá, Austrália, Japão, Hong Kong, África do Sul e Brasil possuem um sistema de avaliação ambiental de edifícios (SILVA, 2007).

Os sistemas de avaliação ambiental de edifícios são ferramentas importantes, que permitem incentivar e auxiliar a implementação de green buildings. Tais sistemas são, normalmente, compostos por um determinado conjunto de indicadores e critérios geralmente baseados na avaliação do desempenho ambiental do ciclo de vida de um edifício ou de seus subsistemas 
(LARSSON, 2004). Estes indicadores de desempenho atribuem uma pontuação técnica em função do grau de atendimento a requisitos especificados em cada sistema e possuem ponderações, explicitas ou não, que retratam os principais problemas ambientais locais (TÉCHNE, 2008).

A maioria dos sistemas adequa-se melhor à avaliação de edifícios novos ou projetos, trabalhando no plano do desempenho potencial que é previsto antes de sua construção, sendo raros os exemplos de sistemas voltados à etapa de uso (SILVA, 2007). Os sistemas hoje distinguem claramente entre o desempenho ambiental com base em propriedades inerentes ao edifício (desempenho potencial) e o desempenho real do edifício em operação.

A estrutura destes sistemas (nomes, conteúdo e nível de detalhamento das categorias) varia, porém, dentro de blocos de discussão e requisitos relativamente comuns. Estes sistemas são uma criação e adaptação locais, em função das circunstancias contextuais (legislação, realidade e necessidades) e das aplicações pretendidas, desde ferramentas de apoio ao projeto até ferramentas de avaliação pós-ocupação (SILVA, 2007).

Silva (2007) coloca que todos os sistemas enfocam apenas a dimensão ambiental, uma vez que estão baseados em modelos elaborados por países desenvolvidos, enquanto que os modelos dos países em desenvolvimento deveriam procurar avaliar a sustentabilidade dos edifícios. Nos países desenvolvidos a sociedade já encontrou equilíbrio de qualidade de vida, igualdade social e distribuição de riqueza (ou ao menos de eliminação de extremos de desigualdade) e a prioridade passa a ser reduzir o consumo de recursos e os impactos ambientais (SILVA et al., 2004).

Para Pardini (2009) as preocupações-chaves da sustentabilidade em edificações deveriam abranger a dimensão ambiental e social e variar de acordo com a realidade do país avaliado. Tendo assim edificações focadas: no uso eficiente dos recursos naturais: água, energia e materiais brutos; na poluição do ar e das águas; na minimização dos resíduos sólidos, pela disposição correta destes e pela reciclagem e reaproveitamento de materiais; na qualidade do ambiente interno e na preocupação com o entorno e com a comunidade local. 
A seguir apresentaremos os sistemas de avaliação ambiental de edifícios LEED e Processo AQUA.

\subsubsection{CERTIFICAÇÃO LEED}

O LEED foi elaborado e publicado nos Estados Unidos, pelo United States Green Building Council (USGBC) ${ }^{1}$, com o intuito motivar e acelerar o desenvolvimento de práticas sustentáveis por meio da criação e implementação de critérios de desempenho e ferramentas universalmente entendidas e aceitas (USGBC, 2010).

Os fatos históricos mais marcantes do LEED-NC foram segundo Hernandes (2006):

> 1998 - LEED-NC v1.0 é lançado pelo USGBC.

$>2000$ - LEED-NC v2.0 é lançado com alterações significativas de conteúdo.

> 2002 - LEED-NC v2.1 é lançado com pequenas alterações principalmente no processo burocrático da certificação.

> 2005 - LEED-NC v2.2 é lançado com atualizações de normas, definições mais claras e pequenas alterações de conteúdo.

> 2009 - LEED-NC v3.0 é lançado com três alterações significativas em relação à harmonização, ponderação de créditos e regionalização (USGBC, 2010).

$>$ LEED-NC v3.0 Brasil ainda não sofreu interpretações e adaptações com foco na criação de pontos dedicados para regionalização e alterações no sistema de pontuação e ponderação de créditos (GBC Brasil, 2012).

O LEED foi evoluindo conforme a demanda, e novas versões foram lançadas desde 2004, para atender mais especificamente ás diversas tipologias de construção como seguem (USGBC, 2010):

$>$ LEED-NC (New construction and major renovations): para edifícios novos e grandes reformas;

$>$ LEED-EB (Existing building operations): para operação e manutenção dos edifícios existentes;

$>$ LEED-CI (Commercial interiors projects): para interiores comerciais;

$>$ LEED-CS (Core and Shell projects): para estruturas e coberturas;

\footnotetext{
${ }^{1}$ USGBC é uma organização sem fins lucrativos que tem por finalidade a divulgação de práticas sustentáveis em edifícios. É formada por mais de 12.000 organizações da indústria de construção.
} 
$>$ LEED for schools: para escolas;

$>$ LEED for retail: para centros comerciais e pequenas lojas;

$>$ LEED for healthcare: para hospitais;

$>$ LEED-H (Homes): para casas;

> LEED-ND (Neighborhood developments): para vizinhanças/ bairros.

A certificação LEED é baseada em exigências de desempenho e toma por referência princípios ambientais e de uso de energia consolidados em normas e recomendações de organismos norte-americanos com credibilidade reconhecida como a ASHRAE- American Society of Heating, Refrigerating and Air Conditionning Engineers (Sociedade Americana de Engenheiros de Aquecimento, Refrigeração e Ar Condicionado), a ASTM - American Society for Testing and Materials (Sociedade Americana de Ensaios e Materiais), a EPA U.S. Environmental Protection Agency (Agência Americana de Proteção Ambiental) e o DOE - U.S. Department of Energy (Departamento Americano de Energia) para estimular estratégias sustentáveis (FOSSATI, 2008).

No LEED, os empreendimentos são avaliados segundo seis categorias de requisitos (USGBC, 2010):

1) Sustentabilidade do terreno (01 pré-requisito e 14 créditos);

2) Uso racional da água (05 créditos);

3) Energia e atmosfera (03 pré-requisito e 17 créditos);

4) Materiais e recursos (01 pré-requisito e 13 créditos);

5) Qualidade do ambiente interno (02 pré-requisito e 15 créditos);

6) Inovação e processo do projeto (05 créditos).

Total -69 pontos

Para verificar se um projeto poderá receber um selo LEED este é avaliado através de um chek-list padronizado, que aborda todos os requisitos das categorias. Cada um desses requisitos é desdobrado em itens (que são ações de projeto, construção e gerenciamento que contribuíram a reduzir o impacto ambiental do edifício) e cada um destes deve ser avaliado individualmente. A cada item avaliado são atribuídos pontos que, somados, devem atingir patamares pré-determinados para obtenção da certificação em diferentes níveis de classificação. Quanto maior o cumprimento dos requisitos maior o número de 
pontos atingidos, o que resulta, em um projeto que têm grande potencial, para ganhar o selo de maior valor (VOSGUERITCHIAN, 2006).

Todas as categorias têm o peso definido pelo número de requisitos exigidos. Isto é, não há ponderação entre as categorias já que todos os créditos possuem o mesmo peso, mas o número variável de itens dentro de cada categoria acaba por definir pesos para cada uma delas (FOSSATI, 2008).

É importante ressaltar que alguns dos itens são considerados "obrigatórios", chamados de "pré-requisitos" e se estes não estão de acordo com as normas estabelecidas não poderá ser avaliado e certificado. O critério mínimo para um empreendimento ser elegível à certificação é o cumprimento dos 7 pré-requisitos.

Os níveis de classificação estão divididos em quatro categorias (USGBC, 2010):

$>$ LEED Platina (52-69 pontos)

$>$ LEED Ouro (39-51 pontos)

$>$ LEED Prata (33-38 pontos)

$>$ Certificação (26-32 pontos)

A certificação LEED é valida por um período de 5 anos e após este período deverá ser encaminhada uma nova solicitação de avaliação em outra versão apropriada do USGBC, desta vez centrada na avaliação da operação e gestão do empreendimento como o LEED Existing Building ou LEED Commercial Interiors (FOSSATI, 2008).

\section{Processo de certificação}

O processo de certificação permeia todo o processo de projeto e construção da edificação, desde o projeto básico até antes da pós-ocupação, de modo que a eficiência e o desempenho ambiental do edifício de forma global sejam sistematicamente identificados, medidos e informados, tendo em vista reduzir o impacto ambiental do edifício, conforme apresentado na figura a seguir: 
Figura 1:Etapas do processo de certificação LEED

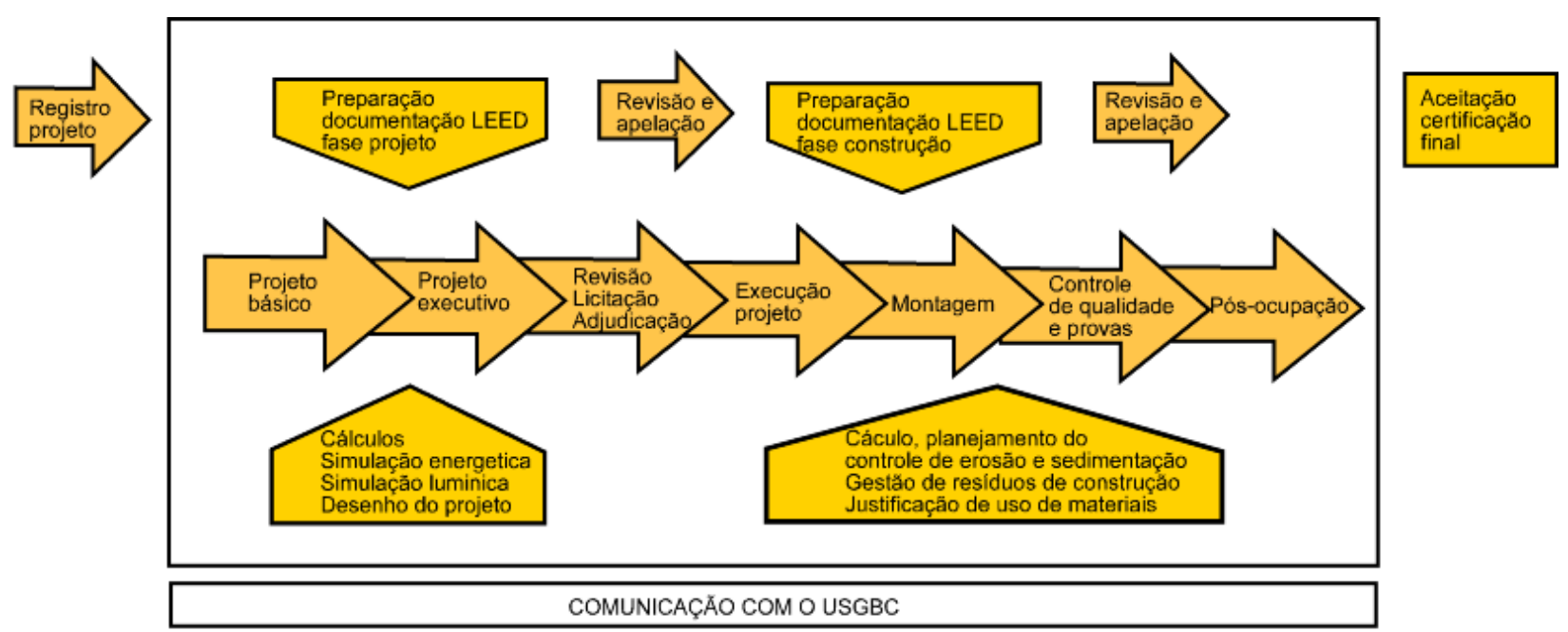

Fonte: Adaptação do gráfico de (ISERN,2010)

Muito resumidamente, o processo de certificação LEED efetivo assenta no desenvolvimento das seguintes etapas (SOUZA, 2007):

$>$ Elegibilidade: em termos de elegibilidade do projeto não foram postos limites.

$>$ Registro: envolve fornecer ao USGBC informação do projeto através do preenchimento do formulário de inscrição online. Há um custo associado ao registro, que esta baseada na área do edifício dada em $\mathrm{m}^{2}$. Uma vez o projeto inscrito a equipe de projetistas, ou entidade responsável pelo mesmo, começa a preparar a documentação e os cálculos necessários à satisfação dos pré-requisitos e créditos que vão ser sujeitos a avaliação.

$>$ Interpretação dos requisitos (isto é dos créditos e pré-requisitos): devido a que existem diferentes tipos de projetos, surgem frequentemente duvidas acerca da aplicação de algum pré-requisito ou credito a um determinado projeto. O USGBC estabeleceu um processo de análise registrado para o esclarecimento dessas duvidas que possam surgir, denomina-se pedidos de interpretação dos créditos (CIRs), de modo de garantir que as regras aplicadas sejam consistentes e estejam disponíveis para outros projetos.

$>$ Certificação e documentação: de modo a ser certificado sob o selo LEED o projeto candidato deve satisfazer todos os pré-requisitos e um número mínimo de pontos para alcançar um determinado nível de certificação. 
Quadro 4: Principais dificuldades encontradas pelas empresas

\begin{tabular}{|c|c|c|}
\hline Dimensão & Dificuldade & Autor \\
\hline \multirow{7}{*}{ Economia } & Alto custo (monetário, de tempo e esforço) da certificação & $\begin{array}{l}\text { Schendler e Udall } \\
\text { (2005) }\end{array}$ \\
\hline & Custo da documentação & \multirow{4}{*}{ Johnson (2005) } \\
\hline & Custo direto da certificação & \\
\hline & Custo do projeto e construção & \\
\hline & Proprietário incapaz de se recuperar dos aumentos nos custos & \\
\hline & Prazo de recuperação do retorno do investimento muito longo & $\begin{array}{l}\text { Cryer et al., } \\
(2006)\end{array}$ \\
\hline & Falta de recurso & $\begin{array}{l}\text { Hanby (2004) } \\
\text { apud Da Silva } \\
(2008)\end{array}$ \\
\hline \multirow{8}{*}{ Produção } & $\begin{array}{l}\text { Planejamento inadequado com os empreiteiros e } \\
\text { subempreiteiros }\end{array}$ & Cooper (2002) \\
\hline & Incapacidade de se atender os pré-requisitos do LEED & \multirow{2}{*}{ Johnson (2005) } \\
\hline & Os creditos não são suficientes para se qualificar & \\
\hline & Não cumprimento dos prazos de entrega & Silva (2010) \\
\hline & $\begin{array}{l}\text { Problemas em encontrar fornecedores de materiais e soluções } \\
\text { tecnológicas para atender aos requisitos da certificação }\end{array}$ & Pardini (2009) \\
\hline & Complexidade da simulação energética requerida & $\begin{array}{l}\text { Schendler e Udall } \\
\text { (2005) }\end{array}$ \\
\hline & Falta de informações para o entendimento e avaliação & Davies (2005) \\
\hline & Maior complexidade na construção & $\begin{array}{l}\text { Cryer et al., } \\
(2006)\end{array}$ \\
\hline \multirow{4}{*}{ Informação } & Comunicação/desentendimento com o USGBC & Johnson (2005) \\
\hline & Falha na comunicação & \multirow{2}{*}{$\begin{array}{l}\text { Cooper }(2002) \text { e } \\
\text { Schendler e Udall } \\
(2005)\end{array}$} \\
\hline & Burocracia engessada & \\
\hline & Documentação LEED & $\begin{array}{c}\text { Cryer et al., } \\
(2006)\end{array}$ \\
\hline \multirow{2}{*}{ Governo } & Falhas na legislação & Piccoli (2009) \\
\hline & Falta de politicas e icentivos & Wood (2007) \\
\hline \multirow{9}{*}{ Recursos humanos } & Falta de treinamento e educação & $\begin{array}{l}\text { Landman show } \\
\text { (1999) apud Da } \\
\text { Silva (2008) }\end{array}$ \\
\hline & Desinformação dos profissionais & Piccoli (2009) \\
\hline & Falta de experiência no LEED dos integrantes da equipe & \multirow{3}{*}{ Johnson (2005) } \\
\hline & Deficiente comunicação/educação da equipe & \\
\hline & Rotatividade da equipe de projeto & \\
\hline & $\begin{array}{l}\text { Falta de conhecimento especifico, de treinamento e de } \\
\text { familiaridade de clientes, construtoras e fornecedores }\end{array}$ & Davies (2005) \\
\hline & $\begin{array}{l}\text { Falta de conhecimento e parâmetros para ter como experiência } \\
\text { inicial }\end{array}$ & Pardini (2009) \\
\hline & Falta de pessoal treinado & \\
\hline & Falta de conscientização & $\begin{array}{l}\text { Cryer et al., } \\
(2006)\end{array}$ \\
\hline \multirow[t]{2}{*}{ Gestão } & Falta de aceitação & $\begin{array}{l}\text { Hanby (2004) } \\
\text { apud Da Silva } \\
(2008)\end{array}$ \\
\hline & Falta de um processo de projeto integrado & Da Silva (2008) \\
\hline
\end{tabular}


O USGBC sugere que um Professional LEED AP seja a pessoa de contato no registro do projeto com o USGBC e que seja membro da equipe responsável pela documentação. $\mathrm{O}$ Professional LEED AP é um individuo que tem demonstrado grande conhecimento acerca da construção sustentável e do processo de certificação LEED. Esta acreditação é concedida depois de realizarem um exame técnico avaliado pelo GBC Brasil.

\subsubsection{PROCESSO AQUA}

No Brasil, em outubro de 2007, o processo AQUA foi implantado pela Fundação Carlos Alberto Vanzolini-FCAV ${ }^{2}$, com base na correspondente francesa Démarche HQE. O processo AQUA tem o objetivo de obter a qualidade ambiental de um empreendimento novo ou envolvendo uma reabilitação (FCAV, 2010).

O trabalho de tradução e de adaptação foram realizados pela Fundação Carlos Alberto Vanzolini em parceria com a Escola Politécnica da USP, em um convenio de cooperação com a Certivéa ${ }^{3}$, na França. Este trabalho de adaptação gerou um documento chamado Referencial Técnico de Certificação, que contemplava escritórios e edifícios escolares.

A estrutura do processo AQUA é idêntica à descrita sobre o $\mathrm{HQE}$, mudando só os parâmetros de exigência das categorias (HILGENBERG, 2010). Para Negreiros (2009), a estrutura do Processo AQUA apresenta indicadores de desempenho mais completos e mais flexíveis do que o original francês, dando ao método maior liberdade de projeto e inovação.

De acordo com a FCAV (2010), a obtenção do desempenho ambiental de uma construção envolve tanto questões de gestão ambiental como de natureza arquitetônica e técnica. Por esta razão, o referencial técnico estrutura-se em dois elementos, que avaliam o empreendimento de maneiras complementares (FCAV, 2010):

$>$ O referencial do Sistema de Gestão do Empreendimento (SGE), para avaliar o sistema de gestão do empreendimento desenvolvido pelo empreendedor para assegurar a qualidade ambiental final de sua construção;

\footnotetext{
${ }^{2}$ FCAV é uma instituição privada sem fins lucrativos que tem por finalidade desenvolver e difundir atividades de caráter inovador na área de engenharia da produção e administração de operações.

${ }^{3}$ Certivéa (filial do CSTB para certificações).
} 
> O referencial da Qualidade Ambiental do Edifício (QAE), para avaliar o desempenho do empreendimento de acordo com suas características arquitetônicas e técnicas.

A implementação do Sistema de Gestão do Empreendimento (SGE) permite definir a Qualidade ambiental visada para o edifício e organiza o empreendimento para atingi-la, ao mesmo tempo permite controlar o conjunto de processos operacionais relacionados às fases de avaliação da QAE. Cabe ao empreendedor definir a organização, as competências, o método, os meios de documentação necessários para alcançar seus objetivos e atender as necessidades e às expectativas das partes interessadas e às exigências do Processo AQUA. Se o empreendedor decide implementar as exigências desta certificação em seu empreendimento este pode implementar um sistema de gestão ambiental (SGA) conforme com a norma NBR ISSO 14.001 "Sistemas de gestão ambiental” (FCAV, 2010).

O empreendimento também é avaliado em três fases distintas (FCAV, 2010):

> Programa: fase durante na qual se elabora o programa de necessidades (definição das necessidades e o desempenho do projeto), documento destinado aos projetistas para a concepção arquitetônica e técnica do empreendimento;

> Concepção: fase durante na qual os projetistas, com base nas informações do programa, elaboram a concepção arquitetônica e técnica do empreendimento;

$>$ Realização: fase durante na qual os projetos são construídos, tendo como resultado a construção do empreendimento.

Em cada uma destas fases, o empreendimento passa por auditorias e recebe uma certificação daquela fase. O referencial do Sistema de Gestão do Empreendimento (SGE) organiza-se de acordo com os seguintes capítulos (FCAV, 2010):

$>$ Comprometimento do empreendedor, no qual são descritos os elementos de análise solicitados para a definição do perfil ambiental do empreendimento e as exigências para formalizar tal comprometimento;

$>$ Implementação e funcionamento, no qual são descritas as exigências em termos de organização; 
$>$ Gestão do empreendimento, no qual são descritas as exigências em termos de monitoramento e análises criticas dos processos, de avaliação da QAE e de correções e ações corretivas;

$>$ Aprendizagem, onde são descritas as exigências em termos de aprendizagem da experiência e de balanço do empreendimento.

A Qualidade Ambiental do Edifício estrutura-se em 14 categorias (conjunto de preocupações ambientais) divididas em 4 bases de ação (FCAV, 2010):

\section{ECOCONSTRUÇÃO}

> Categoria n $n^{o}$ 1: Relação do edifício com o seu entorno

$>$ Categoria $n^{0}$ 2: Escolha integrada de projetos, sistemas e processos construtivos

$>$ Categoria n ${ }^{\circ}$ 3: Canteiro de obras com baixo impacto ambiental

\section{ECOGESTÃO}

$>$ Categoria nº 4: Gestão da energia

> Categoria n5: Gestão da água

$>$ Categoria no 6: Gestão dos resíduos de uso e operação do edifício

> Categoria n ${ }^{\circ}$ 7: Manutenção - Permanência do desempenho ambiental

\section{CONFORTO}

$>$ Categoria n ${ }^{0}$ 8: Conforto higrotérmico

$>$ Categoria n'9: Conforto acústico

$>$ Categoria $n^{\circ}$ 10: Conforto visual

$>$ Categoria $n^{\circ}$ 11: Conforto olfativo

\section{SAÚDE}

> Categoria nº 12: Qualidade sanitária dos ambientes

> Categoria no 13: Qualidade sanitária do ar

> Categoria n 14:Qualidade sanitária da água 
Dentro das 14 categorias, existem 38 subcategorias que se desdobram em cerca de 160 preocupações, das quais mais de $40 \%$ são obrigatórias para se atingir o conceito mínimo bom em cada categoria (HILGENBERG, 2010).

O desempenho associado a cada uma das categorias da Qualidade Ambiental do Edifício (QAE) se expressa segundo três níveis (FCAV, 2010):

> Bom: nível correspondendo ao desempenho mínimo aceitável para um empreendimento de Alta Qualidade Ambiental. Isso pode corresponder à regulamentação se esta é suficientemente exigente quanto aos desempenhos de um empreendimento, ou , na ausência desta, à pratica corrente.

$>$ Superior: nível correspondendo ao das boas práticas de sustentabilidade.

> Excelente: nível que corresponde aos desempenhos máximos constatados em empreendimentos de Alta Qualidade Ambiental, mas somente caso eles possam ser atingíveis.

O recurso utilizado em substituição à ponderação é a elaboração de perfis de desempenho que priorizam a importância das categorias. A definição do perfil é feita tomando em conta as características, vantagens e desvantagens em relação ao ambiente do local onde o empreendimento será inserido, as exigências legais e regulamentares pertinentes, as necessidades e expectativas das partes interessadas e os objetivos ambientais do empreendedor (RODRIGO e CARDOSO, 2010).

Para que um empreendimento obtenha a certificação é exigido que o perfil de desempenho nas 14 categorias seja, pelo menos, excelente em 3 categorias, superior em 4 e no máximo bom em 7 .

\section{Processo de certificação}

O processo AQUA se insere transversalmente ao processo tradicional de gestão de um empreendimento e interfere desde o programa até a fase de realização, de modo que o desempenho ambiental do edifício seja avaliado e certificado durante todo o seu desenvolvimento, conforme apresentado na figura a seguir: 
Figura 2:Fases do processo de certificação AQUA

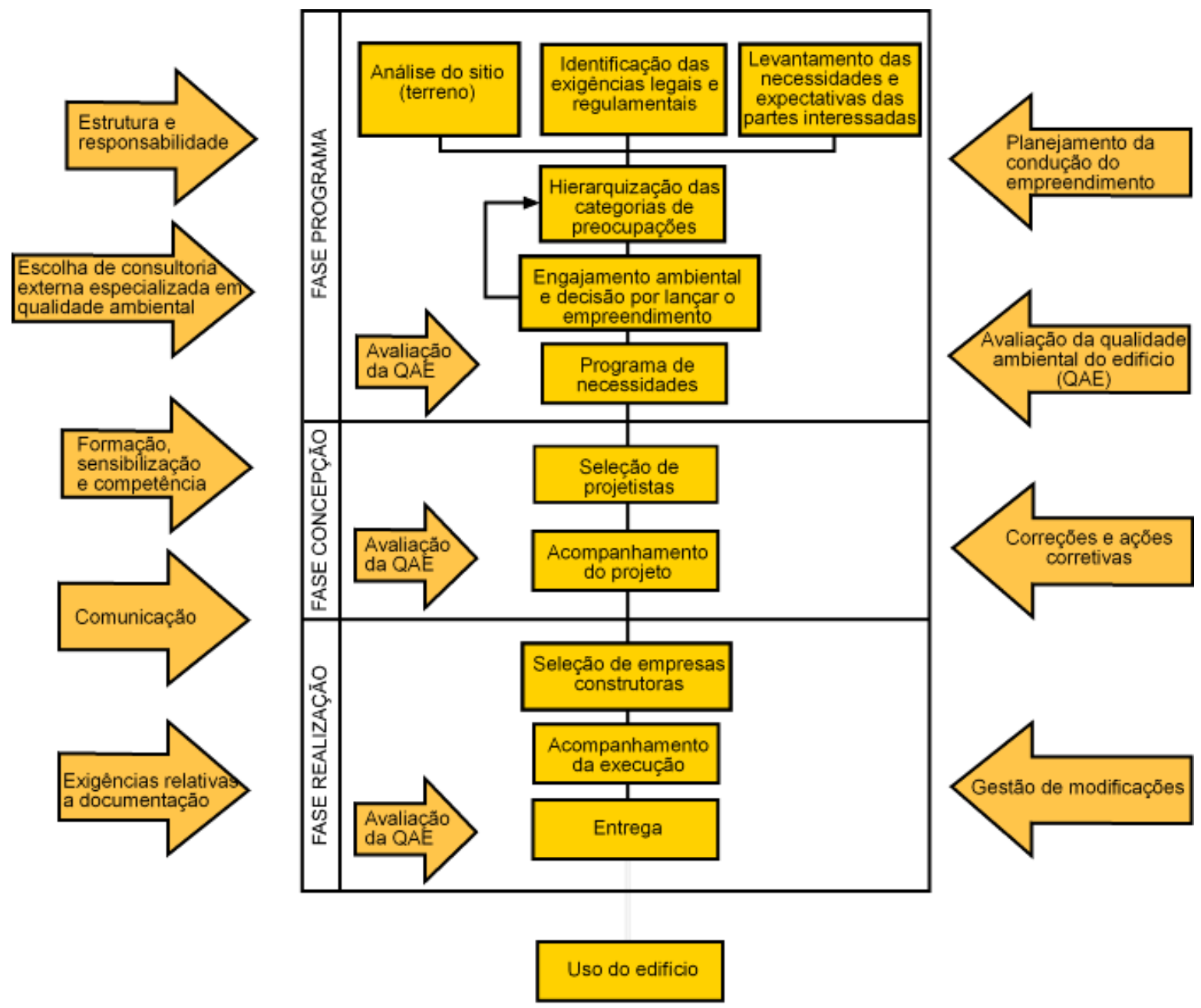

Fonte: Adaptação do gráfico de (CARDOSO, 2003)

Muito resumidamente, o Processo AQUA efetivo contempla o desenvolvimento das seguintes etapas (FCAV, 2010):

$>$ Fase programa: o empreendedor deve definir o programa de necessidades do empreendimento e o perfil de desempenho nas 14 categorias do Processo AQUA, assumindo o compromisso e assegurando os recursos para obter o perfil programado. Deve ainda estabelecer um sistema de gestão do empreendimento SGE, para assegurar o controle total do projeto, até a conclusão da obra, a fim de garantir que os objetivos propostos sejam alcançados. Finalmente, deve avaliar a qualidade ambiental do edifício - QAE e corrigir eventuais desvios. A auditoria de 
certificação é agendada mediante solicitação do empreendedor e envio, à Fundação Vanzolini, de um dossiê contendo o programa e a avaliação da QAE.

$>$ Fase concepção (projetos): o empreendedor utiliza o perfil de desempenho programado nas 14 categorias de desempenho do Processo AQUA e os demais elementos do programa como entrada para os projetos. Mantém o SGE, avalia a capacidade e competência dos intervenientes técnicos, elabora os projetos, designa um coordenador da concepção arquitetônica e técnica do empreendimento projetado, avalia o perfil da QAE e corrige eventuais desvios. A auditoria de certificação é agendada mediante solicitação do empreendedor e envio à Fundação Vanzolini da avaliação da QAE no momento do pedido do alvará para o inicio das obras e durante a escolha e contratação das empresas construtoras (construtora e subempreiteiros).

$>$ Fase realização (obra): o empreendedor mantém o SGE, realiza a obra, avalia a capacidade e responsabilidade dos intervenientes, avalia o perfil da QAE e corrige eventuais desvios. A auditoria de certificação é agendada mediante solicitação do empreendedor e envio à Fundação Vanzolini da avaliação da QAE no momento da entrega do empreendimento. 


\subsection{AS MOTIVAÇÕES, BENEFÍCIOS E DIFICULDADES DA ADOÇÃO DE SISTEMAS DE AVALIAÇÃO AMBIENTAL DE EDIFÍCIOS}

A pesquisa da literatura revela que internacionalmente foram desenvolvidos diversos estudos com o objetivo de mapear as motivações para a adoção da certificação LEED, bem como os benefícios e dificuldades inerentes a este processo. Entre outros, salientam-se os seguintes:

$>$ O estudo de Johnson (2005), que teve como objetivo conhecer as motivações e algumas barreiras à certificação LEED suportando o seu estudo nos dados recolhidos de um questionário enviado a 43 pessoas que trabalharam em empreendimentos registrados junto ao USGBC para obter a certificação LEED.

$>$ O relatório de Cryer et al. (2006), que tem a finalidade de testar algumas de suas hipóteses sobre as oportunidades, barreiras, benefícios, criticas e custos da construção sustentável. Foi realizado um workshop com representantes de organizações ligadas ao mercado imobiliário, com ou sem experiência em questões relacionadas à construção sustentável, e foram estudados 235 projetos certificados LEED-NC 2.0 e 2.1 para novas construções, no período de 2000 até dezembro de 2005, com a intenção de identificar padrões e tendências.

$>$ O estudo de Da Silva (2008), realizado junto aos profissionais credenciados LEED do Canadá, que permitiu compreender e estudar os green buildings com o propósito de otimizar a implementação da certificação através da melhor aplicação dos créditos do LEED, a fim de reduzir os custos e impactos no cronograma, aumentar os benefícios e melhorar a sustentabilidade no projeto.

$>$ O relatório de Lucuik et al. (2005), que teve como objetivo definir a situação da indústria de construção sustentável no Canadá e fornecer uma base para o reconhecimento dos benefícios que um green building pode oferecer, bem como os desafios e barreiras que enfrenta a indústria canadense. 
$>$ O artigo de Schendler e Udall (2005), que baseado em experiências de dois projetos certificados pelo LEED, explora o que considera errado e inicia uma discussão de como corrigir o que consideram problemas no LEED.

$>\mathrm{O}$ estudo promovido por Wood (2007), num conjunto habitacional destinado a analisar as barreiras relacionadas à concepção e à construção de edificações habitacionais sustentáveis.

$>$ O relatório de Turner Construction Company (2005), que teve como objetivo determinar a percepção de 665 representantes de organizações ligadas ao mercado de construção sustentável quanto a motivações, benefícios e obstáculos ao green building.

A pesquisa da literatura revela que no Brasil vem sendo realizados alguns estudos com o objetivo de estudar as motivações e dificuldades da adoção da certificação LEED e do Processo AQUA. Entre outros, salientam-se os seguintes:

$>$ O estudo conduzido por Pardini (2009), destinado a contribuir para o entendimento da aplicação da certificação LEED e do conceito de custo no ciclo de vida em green building no Brasil, numa amostra constituída por empresas incorporadoras e por profissionais de empresas (ênfase nas incorporadoras) de São Paulo que já vivenciaram algum projeto em busca da certificação.

$>$ O estudo de Piccoli (2009), que teve como objetivo analisar as principais alterações no processo de construção decorrentes da aplicação da certificação LEED em dois casos, sendo um edifício residencial (projeto) e outro comercial (produção).

> O artigo de Rodrigo e Cardoso (2010), que identifica e avalia as alterações no processo de gestão do empreendimento, decorrentes do SGE, e como estas alterações impactam positivamente no desenvolvimento das soluções técnicas para a alta qualidade ambiental do edifício em dois casos, sendo um edifício de escritórios e outro comercial. As alterações foram identificadas a partir de 
entrevistas com os consultores de implantação do Processo AQUA e com um dos empreendedores.

$>$ O artigo de Piccoli et al. (2010), que discute as exigências e as novas atividades na gestão da construção que surgem em decorrência do objetivo de obter a certificação ambiental de edifícios num estudo de caso de um edifício comercial.

Com base nos autores citados e outros, pode-se detalhar as principais motivações, benefícios e dificuldades dos sistemas de avaliação ambiental de edifícios.

\subsubsection{AS MOTIVAÇÕES}

O termo "motivação" é definido pelo Dicionário Mini Aurélio da Língua Portuguesa (2008) como " o conjunto de fatores que determinam a atividade e a conduta individuais". Assim, nesta dissertação assume-se que as "motivações" para a implementação da certificação ambiental de edifícios são atreladas as filosofias e estratégias das organizações que procuram um sistema de avaliação ambiental de edifícios. Certamente os benefícios presumidos são também motivações para adoção de Green buildings e das certificações, porém são questões mais pragmáticas e mensuráveis, conforme será discutido no próximo item deste trabalho.

O levantamento das motivações para a construção de edifícios sustentáveis e a adoção dos sistemas de avaliação ambiental de edifícios foi efetuado com base na literatura disponível sobre o assunto. Foram sistematizados diversos autores que apresentam as motivações para implementar ações ambientais nas grandes empresas e para as certificações LEED e Processo AQUA, os principais trabalhos utilizados foram o de Johnson (2005) e Turner Green Market Barometer (2010). Buscou-se efetuar a sua divisão conforme a dimensão em que elas se enquadram. O resultado dessa divisão é um conjunto de motivações organizado em oito dimensões diferentes, demonstrada no Quadro 1: 
Quadro 1: Principais motivações para a adoção dos sistemas de avaliação ambiental de edifícios

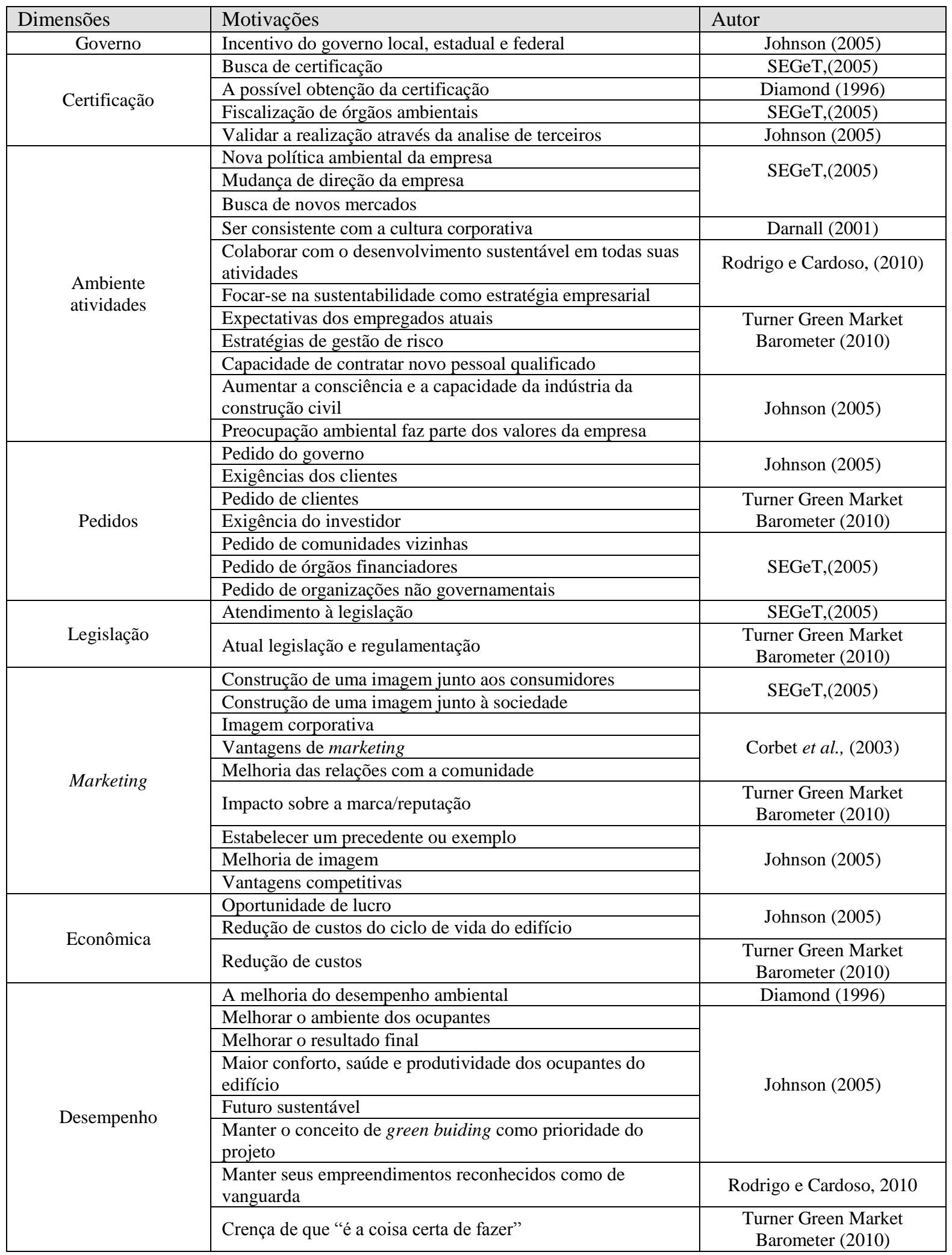




\section{Motivações para a construção de green buildings}

É importante destacar que os benefícios decorrentes da construção de um green building são independentes das certificações. As partes envolvidas neste tipo de edifício possuem interesses divergentes nos benefícios, para o empreendedor é pelo TIR (Taxa interna de retorno), Pay-Back (Prazo de recuperação), retorno sobre o investimento, custo da construção (curto prazo), valor e velocidade de venda; e para o usuário, o interesse é pelo conforto, saúde e custos inicial e de operação a longo prazo.

Segundo Pardini (2009) o processo de decisão do incorporador/investidor por construir ou não um edifício sustentável é embasada por um estudo de viabilidade confiável aliado à análise qualitativa do empreendimento, permitindo que os ganhos sejam efetivamente convertidos em lucro. Nesse sentido, edifícios sustentáveis se transformam em opção quando se estende o olhar para toda sua vida útil considerando além dos investimentos iniciais, todos os custos incorridos ao longo do seu ciclo de vida, pois enquanto as externalidades ambientais não forem de algum modo contabilizados, a decisão poderá ainda ser difícil. Já os usuários que preferem edifícios sustentáveis são aqueles que conhecem as economias decorrentes deste tipo de edifícios, como redução de condomínio, seguro e operação (PARDINI, 2009).

Davies (2005) apud Pardini (2009) analisou 12 empreendimentos localizados nos EUA e Canadá, e identificou que a motivação para a concepção de projetos de edifícios sustentáveis partiu em $75 \%$ dos casos do interesse do proprietário/investidor, motivados por seus valores seguidos pelo diferencial de mercado. Porém, as questões relacionadas à imagem da organização diante da responsabilidade corporativa ambiental são de grande interesse quando do desenvolvimento de um projeto sustentável.

Os resultados do relatório de Turner Green Building Market Barometer (2010) sobre a percepção de 681 representantes de organizações ligadas ao mercado de construção sustentável dos EUA, quanto às motivações que levam as pessoas a incorporar estratégias sustentáveis em projetos de edifício, acompanhados das respectivas percentagens de resposta indicadas entre parêntesis, foram: 
> Impacto sobre a marca/reputação (64\%);

$>$ Redução de custos (64\%);

$>$ Crença de que "é a coisa certa a fazer" (63\%);

$>$ Exigência do cliente (59\%);

> Aguarda legislação e regulamentação (40\%);

$>$ Exigência dos investidores (40\%);

> Atual legislação e regulamentação (40\%);

$>$ Expectativas dos atuais empregados (36\%);

$>$ Estratégias de gestão de risco (36\%);

$>$ Capacidade de contratar novo pessoal qualificado (33\%).

Estes dois estudos confirmam que o principal motivo para uma organização construir um edifício sustentável nos EUA é de melhorar sua imagem. Tzschentkr et al., (2004) ratificam igualmente que um dos principais motivos para a introdução de medidas ambientais é a possibilidade de redução de custos pelo aumento da eficiência operacional. Nesse sentido, a busca por alternativas é impulsionada pelo aumento das taxas de água, energia e resíduos. Por outro lado, a questão ética e social expressa-se na forma de simples obrigação moral, desejo de contribuir ou na citação "fazer a minha parte para as futuras gerações".

No município de Florianópolis, o trabalho desenvolvido por Pires et al. (2008), identificou que os motivos que levaram a seis empresas construtoras a desenvolver empreendimentos de edifícios sustentáveis devem-se principalmente à consciência ambiental dos gestores da empresa, à preocupação ambiental, à legislação vigente, aos benefícios que este tipo de construção proporciona para os consumidores e por eles representarem uma estratégia de marketing de baixo custo.

Rodrigo e Cardoso (2010), em dois estudos de caso realizados no Brasil, um edifício de escritórios e outro comercial, identificaram que os motivos principais para essas empresas construir edifícios sustentáveis, foram os seguintes:

$>$ Colaborar com o desenvolvimento sustentável em todas suas atividades;

$>$ Focar-se na sustentabilidade como estratégia empresarial; 
$>$ Manter seus empreendimentos, reconhecidos como de vanguarda.

De acordo com Pearce et al. (2005), as motivações que estimulam as pessoas a incorporar práticas de construção sustentável em seus projetos, podem variar de:

> Motivação interna, tais como, por exemplo, "algumas pessoas se convencem, após várias informações, que gostariam de tentar práticas de construção sustentável em seus próprios empreendimentos". Este processo se dá em três passos: conscientização, conhecimento e persuasão.

> Motivações externas, tais como, por exemplo, as "ordens executivas", legislação ou políticas internas que encorajam ou exigem práticas de green building.

No estado da Califórnia, por exemplo, a adoção de práticas de green buildings foi fruto da preocupação para tentar resolver uma série de desafios, tais como (KATS, 2003):

$>$ Alto custo de energia elétrica;

$>$ Problemas de suprimento de energia, associados a qualidade e disponibilidade;

$>$ Possibilidade de racionamento de água e problemas com disposição de resíduos;

$>$ Pressões estadual e federal para minimizar fatores poluentes;

$>$ Crescente preocupação com o aquecimento global;

> Crescente incidência de alergias e asma, especialmente em crianças;

> Saúde e produtividade dos trabalhadores;

$>$ Efeitos do ambiente físico das escolas no aprendizado das crianças;

$>$ Crescentes despesas na operação e manutenção dos sistemas prediais em prédios do governo ao longo do tempo.

Os níveis de governo (estadual, federal, municipal) ${ }^{4}$ assumem um papel preponderante na promoção e no inicio da implementação de práticas sustentáveis no setor da construção,

\footnotetext{
${ }^{4}$ No Canadá cada nível de governo abraçou a indústria da construção sustentável em diferentes graus. Nos edifícios pertencentes ao governo federal foram incorporadas mudanças e disponibilizados vários incentivos para as outras partes interessadas em construções sustentáveis (LUCUIK et al., 2005).

No governo provincial e territorial, o suporte consiste em programas de demonstração /educação, e um enfoque na eficiência energética nos seus prédios. Em alguns municípios como Vancouver, Markham and Calgary passou a ser obrigatório as praticas sustentáveis nos edifícios dos governos municipais. Vários municípios já tomaram medidas para controlar a expansão urbana, e alguns oferecem incentivos
} 
seja através do desenvolvimento de uma política ambiental clara neste sentido, através do incentivo às pesquisas relativas ao tema ou mesmo pela criação de leis, regulamentações, programas de incentivos da construção sustentável, códigos, acordos públicos/privados e instrumentos financeiros que incentivem uma resposta positiva por parte do mercado (SERRADOR, 2008). De igual modo, a formação de entidades não governamentais também vem contribuindo para o incentivo da sustentabilidade na construção civil em todo o mundo (PARDINI, 2009).

No Brasil, devido à Copa do Mundo 2014, as prefeituras do Rio de Janeiro e de Belo Horizonte criaram os selos Qualiverde (legislação para construções verdes) e BH sustentável (politica pública) respectivamente, para que os empreendimentos adotem alguns parâmetros de sustentabilidade em sua construção. Nos estados que não vão sediar a Copa do Mundo, ainda não se vê evolução parecida, pois a possibilidade de redução fiscal para edifícios sustentáveis é visto com ceticismo. No Brasil, a arrecadação dos estados e municípios frequentemente já está em boa parte comprometida, e dependem dela para sua própria sobrevivência. Por isso os caminhos têm que ser outros, como por exemplo: a criação de linhas especiais de financiamento bancário (SILVA, 2010).

Os arquitetos têm de poder influenciar os investidores e usuários do ambiente construído para um processo construtivo, de apropriação e uso sustentáveis (VILLELA, 2007). De alguns anos para cá, a profissão do arquiteto vem se conscientizando cada vez mais com a questão da sustentabilidade, entre as razões para que promovam os green building, que tem a ver com a qualidade de arquitetura e com razões ambientais, econômicas e espaciais (THE EUROPEAN COMMISSION, 2001).

\section{Motivações para as certificações}

O estudo de Johnson (2005) realizado nos EUA, através de um survey com 43 pessoas de contato dos empreendimentos registrados no LEED, identificou as principais motivações para a adoção da certificação LEED, acompanhadas da respectiva frequência de resposta, indicada entre parêntesis, que são:

aos proprietários de edifícios privados para a adoção de critérios de eficiência energética (LUCUIK et al., 2005). 
> Preocupação ambiental faz parte dos valores da empresa (19);

> Exigências dos clientes (16);

$>$ Estabelecimento de um precedente ou exemplo (6);

$>$ Redução de custos do ciclo de vida do edifício (5)

> Validação da realização através da análise de terceiros (4);

> Melhoria de imagem (3);

$>$ Melhoria do ambiente dos ocupantes (2);

$>$ Melhoria do resultado final (melhor produto/edifício) (2).

> Incentivos do governo local, estadual, federal (2);

$>$ Oportunidade de lucro atestando que o proprietário pode projetar um empreendimento certificado pelo LEED (1);

> Consolidação do conceito de green building como prioridade do projeto (1).

O estudo de Johnson (2005) também questionou quais eram os motivos "Mais influente" ou "Muito influente" para trabalhar em direção à certificação LEED, a seguir se indicam as respostas, acompanhados das respectivas frequências de resposta indicadas entre parêntesis:

> Gestão ambiental (proteção ambiental) (38);

> Manter o conceito de green building como prioridade do projeto (29);

> Validar a realização através da análise de terceiros (21);

$>$ Vantagens competitivas (14);

> Exigências governamentais (12);

$>$ Incentivos do governo local, estadual, federal (7);

$>$ Oportunidade de lucro (3);

$>$ Futuro sustentável (1);

> Aumentar a consciência e a capacidade dentro da indústria da construção civil (1);

> Maior conforto, saúde e produtividade dos ocupantes do edifício (1);

$>$ Demonstrar cuidado por os ocupantes (1);

$>$ "Nossa equipe de projeto adoto o objetivo de alcançar a certificação LEED $e$ continuamos encorajando-nos um ao outro durante todo o processo" (1). 
O estudo de Da Silva (2008), realizado através de um survey com 51 profissionais LEED AP no Canadá, identificou as principais motivações para implementar a certificação LEED, acompanhadas da respectiva frequência de resposta, indicada entre parêntesis, são:

$>$ Gestão ambiental (proteção ambiental) (22);

$>$ Tornar o conceito de green building uma prioridade (23);

> Validar a realização através da análise de terceiros (7);

$>$ Vantagens competitivas (5);

$>$ Incentivos do governo (2);

$>$ Oportunidade de lucro (4).

Nos resultados destes dois estudos abrangendo EUA e Canadá nota-se a coincidência ao nível de três das principais motivações encontradas a gestão ambiental, fazer dos princípios do green building uma prioridade do projeto e a validação da realização através da analise de terceiros. Por outro lado, os estudos de Johnson (2005) e de Da Silva (2008) afirmam que as motivações para a adoção da certificação LEED têm origem nas exigências de proprietários/investidores quando comparada com a influência de outras partes interessadas. Nestes casos a certificação é vista como uma meta a ser atingida a qualquer preço (D’ANGELO et al., 1997).

Com relação ao Processo AQUA as referencias e bibliografias disponíveis são mais restritas seja porque o processo é mais recente, seja porque é um sistema nacional. De qualquer forma, a seguir se faz uma sistematização da bibliografia disponível.

Rodrigo e Cardoso (2010), em dois estudos de caso realizados no Brasil, um edifício de escritórios e outro comercial, identificaram que os motivos principais que levaram a essas empresas a construir edifícios sustentáveis certificados pelo Processo AQUA, foram os seguintes:

$>$ O empreendimento não atendia ao quesito redução no consumo de energia da outra certificação (parâmetro que ainda não foi adaptado a nossa realidade);

$>$ A outra certificação tinha exigências consideradas exageradas e insustentáveis para o contexto brasileiro; 
$>$ Pelo fato de haverem auditorias presenciais.

O processo de obtenção do certificado exige adaptações que despendem grandes esforços e envolve a aplicação de uma gama de recursos por parte da empresa dos quais é razoável se esperar alguma forma de retorno, sendo que um dos motivos mais comuns para a busca da certificação têm fortes conotações mercadológicas (D’ ANGELO et al., 1997). As empresas que exigem a certificação têm uma preocupação maior com o meio ambiente e o consumidor é sem dúvida uma das principais motivações para a certificação ambiental. Para O’Souza (2004) apud Hilgenberg (2010) o consumidor tende a ter escolhas influenciadas por certificações ou selos que um produto possui - o autor reuniu várias pesquisas que mostram que a maior parte dos consumidores prefere comprar um produto que tenha alguma classificação benéfica para o meio ambiente. Por outro lado, muitos consumidores duvidam da reputação e da qualidade dos produtos e serviços sustentáveis, muitas vezes por falta de padrão de informações ou falta de conhecimento. Pensam que sustentabilidade é sinônimo de ecologia, baixa qualidade, rusticidade etc. e que tudo o que é sustentável custa mais caro e não tem ampla oferta no mercado, além de desconhecerem os critérios que os tornam verdes (TÉCHNE, 2010).

Outro fator relacionado à busca da certificação consiste na possibilidade de usar a certificação como estratégia de marketing através da divulgação no material de vendas e diferenciar-se no mercado. Em ambos os casos o retorno obtido é o aumento da velocidade de vendas/locação e melhoria da imagem da empresa. Em geral, as empresas procuram a certificação para atestar a sustentabilidade ambiental dos seus edifícios, que as edificações são melhores e prejudicam menos o meio ambiente.

A certificação possibilita muitos benefícios que podem ou não ser de interesse do proprietário/investidor. Poucas empresas exploram o atendimento às certificações com o objetivo de conseguir retorno econômico normalmente em decorrência de reduzidos conhecimentos e de uma visão preconceituosa em relação ao tema (D' ANGELO et al., 1997). O retorno de investimento é mais importante quando quem construiu é o usuário/proprietário do prédio do que, por exemplo, para o proprietário que constrói para vender (SILVA, 2010; THE EUROPEAN COMMISSION, 2001). O usuário/proprietário ou cliente que encomenda um projeto, uma construção que ele mesmo vai ocupar, uma empresa, ou um prédio público é o principal interessado em ter um bom desempenho a 
longo prazo (THE EUROPEAN COMMISSION, 2001). Existe uma dificuldade para convencer os agentes que constroem ou que incorporam a fazer investimentos, pois não é uma boa aposta para os especuladores imobiliários construir ou incorporar e não poder beneficiar-se da economia a longo prazo (SILVA, 2010). Um período de retorno de quatro anos para o investimento é aceitável para muitos agentes que constroem para vender ou alugar, dado que poderá ser faturado na venda ou locação, sem prejuízo (THE EUROPEAN COMMISSION, 2001).

Pode dar-se o caso que a certificação seja usada como forma de fortalecimento para construir um green building. De fato, ao estabelecer planos e metas para a implementação de green building é necessário definir requisitos, e as certificações especificam os requisitos a serem cumpridos e trazem mecanismos para o controle (chek-list LEED) ou perfil de desempenho ambiental programado (Processo AQUA).

Segundo Turner Green Building Market Barometer (2010), algumas empresas que pretendem comprometer-se com a sustentabilidade mudam suas práticas de negócios e outras simplesmente se engajam em um exercício de relações públicas. O estudo de Cryer et al.(2006) identifica que os fatores alavancadores do crescente número de certificações LEED-NC nos EUA foram:

$>$ A compreensão dos custos e benefícios dos projetos certificados;

$>$ A promulgação das leis locais e estaduais ${ }^{5}$ que, por meio de incentivos e exigências de requisitos mínimos de sustentabilidade a prédios privados e públicos, tornou o processo de certificação (projeto e execução) mais familiar às incorporadoras, despertando nelas a disposição de participar do processo de certificação, diminuindo os riscos associados ao projeto e construção de green building.

As empresas com uma maior dimensão, grande exposição na mídia, carteiras de mais de 1 milhão de $\mathrm{m}^{2}$, maior rentabilidade e maiores despesas em investigação e desenvolvimento

\footnotetext{
${ }^{5}$ A Califórnia (EUA) detêm o maior número de empreendimentos certificados pelo LEED. Neste estado, existem algumas leis chamadas "ordens executivas" (executive orders) que explicitam a preocupação existente com a sustentabilidade na indústria da construção, tanto no desenvolvimento quanto na construção de empreendimentos (PARDINI, 2009).
} 
têm maiores incentivos para procurar as certificações ambientais de edifícios. É o caso das empresas multinacionais, que impulsionam o mercado com sua demanda para atualização de seu portfólio de edifícios produzidos ou facilities próprias. Além disso, o mercado de ações valoriza as práticas sustentáveis no mundo todo. Por exemplo, Dow Jones e Bovespa, criam seus próprios parâmetros de avaliação e assim ranqueiam empresas no mercado, valorizando seus títulos (PARDINI, 2009).

As empresas que impõem a adoção da certificação ambiental para edifícios têm capacidades internas mais fortes do que aquelas que simplesmente encorajam a decisão (PARDINI, 2009). Por exemplo, as que possuem um sistema de gestão e um sistema de gestão ambiental bem estruturado certificados pelas normas NBR ISO 9001 e NBR ISO 14001 apresentam menos barreiras relativamente à implementação do SGE do Processo AQUA.

\section{Mudanças na linha base para desempenho mínimo aceitável}

O segmento de edifícios sustentáveis tem sido alvo de pressões de agentes externos, como o mercado, entidades governamentais (LUCUIK et al. 2005), a sociedade, mas também de algumas das empresas que incorporam a sustentabilidade na estratégia de seus negócios e que buscam instalar suas operações em edifícios sustentáveis (HONDA et al. 2010). Cada vez mais os empreendedores do setor se vêm estimulados a incorporar na prática questões de sustentabilidade na estratégia de seus negócios, induzidos pelas demandas do mercado e restrições legais cada vez maiores, que mudam a linha de base para desempenho mínimo aceitável (HONDA et al., 2010).

De acordo com Honda et al.(2010) e Silva (2003) as mudanças na linha de base para desempenho mínimo aceitável da sustentabilidade de um edifício dependem necessariamente de alterações nas demandas do mercado, sejam elas:

> Voluntárias: quando o mercado impõe pressão no referencial da qualidade da sustentabilidade de um produto para a sua inserção, alterando a linha de base relacionada a um determinado aspecto, local e momento. 
> Involuntárias: relacionadas com alterações legais no desempenho mínimo introduzidas pelos diferentes mecanismos legais (decretos, leis, portarias, normas etc.), no âmbito federal, estadual e municipal.

Para NrCan/CANMET (1998) estas mudanças no desempenho não serão possíveis até que os empreendedores da construção civil e os usuários de edifícios tenham acesso a métodos relativamente simples que lhes permitam reconhecer aqueles edifícios com melhor desempenho. Por exemplo, as normas ABNT NBR 15575 de desempenho para edificações habitacionais de até 5 pavimentos que surgiram no Brasil para estabelecer parâmetros que permitem avaliar o desempenho de edificações.

\subsubsection{OS BENEFÍ́CIOS}

O termo "beneficio" é caracterizado para esta pesquisa como os ganhos, melhorias e economias obtidos pelo edifício certificado, principalmente relacionados a indicadores de desempenho que permitam aferição. Por tanto, benefícios são entendidos nesta dissertação como indicadores mais mensuráveis e de cunho mais pragmático que as motivações.

O levantamento dos benefícios dos edifícios sustentáveis e dos sistemas de avaliação ambiental de edifícios foi efetuado com base na literatura disponível sobre o assunto. Buscou-se efetuar a sua divisão conforme a dimensão em que eles se enquadram. $\mathrm{O}$ trabalho principal utilizado para a divisão das dimensões foi o de Lucuik et al. (2005). O resultado dessa divisão é um conjunto de benefícios organizado em cinco dimensões diferentes, demonstrada no quadro 2: 


\section{Quadro 2: Principais benefícios dos edifícios sustentáveis}

\begin{tabular}{|c|c|c|}
\hline Dimensão & Beneficio & Autor \\
\hline \multirow{11}{*}{ Econômica } & Aumentam o valor do imóvel & \multirow{2}{*}{ Lucuik et al. (2005) } \\
\hline & Ganhos na taxa de absorção & \\
\hline & $\begin{array}{l}\text { Garantem a economia de custos e consumo durante a fase de } \\
\text { construção }\end{array}$ & \multirow{3}{*}{ Menegat (2004) } \\
\hline & Garante maior valor agregado & \\
\hline & Redução de custos de operação e manutenção & \\
\hline & $\begin{array}{l}\text { Torna transparente o valor dos recursos e lucros do } \\
\text { empreendimento }\end{array}$ & \multirow{3}{*}{ GBC Brasil (2012) } \\
\hline & Melhora a produtividade e satisfação dos empregados & \\
\hline & Otimiza o desempenho econômico do ciclo de vida & \\
\hline & Aumenta o retorno sobre investimento (ROI) & \multirow{3}{*}{ McGrawHill (2005) } \\
\hline & Aumenta a velocidade de locação & \\
\hline & Maior taxa de ocupação & \\
\hline \multirow{15}{*}{$\begin{array}{l}\text { Indiretos e } \\
\text { intangíveis }\end{array}$} & Passa imagem de uma empresa ecologicamente correta & \multirow{9}{*}{ Pardini (2009) } \\
\hline & Ganhos e valorização pela mídia & \\
\hline & Valorização pelas empresas multinacionais & \\
\hline & Ganha o respeito e reconhecimento dos consumidores & \\
\hline & Atrai profissionais de talento & \\
\hline & Ganhos subjetivos e intangíveis & \\
\hline & $\begin{array}{l}\text { Ganho para a imagem da organização (ganhos decorrentes da } \\
\text { imagem positiva que as empresas passam para o mercado } \\
\text { com a preocupação sócio-ambiental) }\end{array}$ & \\
\hline & Velocidade maior de venda & \\
\hline & $\begin{array}{l}\text { Aumento da lucratividade na venda e/ou locação das } \\
\text { unidades }\end{array}$ & \\
\hline & Promoção da imagem empresarial & Lam (2004) \\
\hline & Garante um diferencial & \multirow[b]{2}{*}{ Edwards (1998) } \\
\hline & $\begin{array}{l}\text { Melhoria ou a formação de uma imagem corporativa junto a } \\
\text { seus clientes, fornecedores e colaboradores }\end{array}$ & \\
\hline & Aumenta as vendas no varejo & \multirow{2}{*}{ Lucuik et al. (2005) } \\
\hline & Diminuem/evitam riscos & \\
\hline & $\begin{array}{l}\text { Melhora a qualidade do processo de construção e de seus } \\
\text { produtos }\end{array}$ & \\
\hline \multirow{8}{*}{ Ambiente } & Evita danos ambientais & Menegat (2004) \\
\hline & $\begin{array}{l}\text { Reduz danos, aumenta a preservação e até mesmo a } \\
\text { recuperação do meio ambiente }\end{array}$ & Smith (1998) \\
\hline & Melhora o acesso a luz natural e vistas externas & \multirow[t]{2}{*}{ Lucuik et al. (2005) } \\
\hline & Melhora a qualidade do ar & \\
\hline & Melhora a qualidade da água & \multirow[t]{4}{*}{ GBC Brasil (2012) } \\
\hline & Protege os ecossistemas e a biodiversidade & \\
\hline & Reduz os desejos sólidos & \\
\hline & Conserva os recursos naturais & \\
\hline \multirow{7}{*}{ Externos } & Vantagem dentro do mercado competitivo & Edwards (1998) \\
\hline & Tornam os empreendimentos mais atraentes & Menegat (2004) \\
\hline & Traz benefícios em custos da infraestrutura & \multirow[t]{4}{*}{ Lucuik et al. (2005) } \\
\hline & Diminuem impactos e custos ambientais & \\
\hline & Criação de emprego & \\
\hline & $\begin{array}{lcccc}\begin{array}{l}\text { Aumenta } \\
\text { oportunidades de exportação }\end{array} & \text { reconhecimento } & \text { internacional } & \text { e } & \text { cria } \\
\end{array}$ & \\
\hline & Valida a realização através da análise de terceiros & \\
\hline \multirow{4}{*}{$\begin{array}{l}\text { Saúde e } \\
\text { comunidade }\end{array}$} & Melhora na qualidade de vida & Edwards (1998) \\
\hline & Melhora o conforto e saúde dos ocupantes & \multirow[t]{2}{*}{ Lucuik et al. (2005) } \\
\hline & Melhora os ambientes de ar, clima e sonoros & \\
\hline & Minimiza a tensão na infraestrutura & GBC Brasil (2012) \\
\hline
\end{tabular}




\section{Benefícios dos edifícios sustentáveis}

Segundo Lucuik et al. (2005) os green buildings oferecem muitos benefícios para as várias partes interessadas do setor da construção (proprietários, ocupante/usuário final, investidor, vizinho, projetistas, empreendedor e até mesmo para os diversos níveis de governo). Estes autores combinaram numa matriz seus julgamentos subjetivos sobre os benefícios dos edifícios sustentáveis para as partes interessadas, apresentados na figura 3:

Figura 3: Benefícios dos green buildings as partes interessadas

\begin{tabular}{|c|c|c|c|c|c|c|c|c|c|c|}
\hline \multirow{2}{*}{\multicolumn{2}{|c|}{ Incremento de benefícios }} & \multicolumn{9}{|c|}{ Partes interessadas } \\
\hline & & 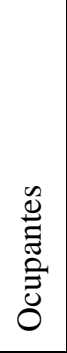 & 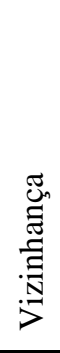 & 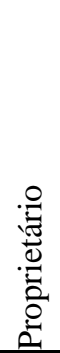 & 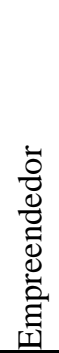 & $\begin{array}{l}\frac{\pi}{0} \\
\frac{0}{2} \\
\frac{0}{2}\end{array}$ & 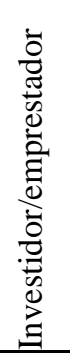 & 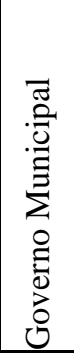 & 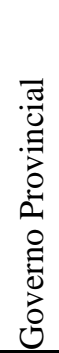 & 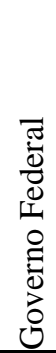 \\
\hline \multirow{7}{*}{ 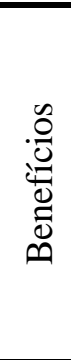 } & Economia & & & & & & & & & \\
\hline & Saúde do usuário & & & & & & & & & \\
\hline & Redução dos riscos & & & & & & & & & \\
\hline & Impacto do câmbio climático & & & & & & & & & \\
\hline & Ecologia & & & & & & & & & \\
\hline & Diminui a desconfiança na infraestrutura & & & & & & & & & \\
\hline & Conforto do usuário & & & & & & & & & \\
\hline
\end{tabular}

Fonte: LUCUIK et al. (2005)

Os benefícios dos edifícios sustentáveis não são todos imediatamente quantificáveis. Alguns são frequentemente ignorados pelos proprietários de edifícios, como os financeiros, taxas e benefícios de marketing e marca relacionada com green building, pois os benefícios gerados por estes edifícios quase sempre são invisíveis e apreciáveis apenas depois de sua ocupação, durante a fase de uso. Alguns benefícios podem ser subjetivos, mas sua inclusão é importante, pois equilibram os custos iniciais que tipicamente são mais mensuráveis.

Vários são os benefícios obtidos com os edifícios sustentáveis. O mais evidente é o ambiental, pois os green buildings são projetados e construídos para consumir menos água, energia, materiais e recursos naturais. Outro beneficio que um green building proporciona é a redução de danos, preservação e renovação do meio ambiente (SMITH, 
1998). Apesar de ser relevante, este beneficio por si só não apresenta respaldo financeiro e ganho mensurável imediato que provoquem o interesse de investidores e garantam a disseminação deste tipo de empreendimento, a não ser que possam ser utilizados na promoção da imagem empresarial (LAM, 2004).

Os benefícios econômicos proporcionados pelos green building têm sido bem documentados. Varias pesquisas realizadas indicam que green building podem reduzir em até $30 \%$ o consumo de energia, $50 \%$ o consumo de água, $90 \%$ o descarte de resíduos, 35\% a emissão de carbono (TÉCHNE, 2010), 13\% os custos de manutenção e também aumentar em 27\% o nível de satisfação dos seus ocupantes (KATS, 2003). Esta redução no consumo de energia e água pode trazer vantagem competitiva em longo prazo para as empresas com custos operacionais significativos (CRYER et al., 2006). Kats (2003) argumenta que "só o investimento em edifícios energeticamente eficientes parece ser economicamente mais eficaz". Um estudo de 2003 da California's Sustainable Building Task Force mostra que um investimento inicial de $2 \%$ no projeto de um edifício sustentável, em média, pode resultar em economias de $20 \%$ dos custos totais de operação: mais de dez vezes o investimento inicial, com base em um período de 20 anos (KATS, 2003).

Enxergar a possibilidade de aumentar os lucros por meio de um empreendimento sustentável significa ir além dos ganhos intangíveis (como a formação de uma boa imagem da marca da incorporadora ou construtora no mercado; a atração de multinacionais para estes empreendimentos e os ganhos em mídia gratuita) abandonando a cômoda rotina e ousando com novos conceitos como: inserção do conceito da análise de custos ao longo do ciclo de vida como parte do processo ou critério de decisão; união de departamentos de compras e manutenção dentro de uma mesma organização; remuneração dos projetistas por desempenho; remuneração da equipe de gestão de facilidades por desempenho e inovação na estrutura de locação (PARDINI, 2009).

Além disso, os green building oferecem melhores condições de trabalho para os ocupantes, incluindo melhor qualidade do ar, conforto térmico e acesso à luz natural, o que reflete no melhor desempenho, produtividade, na redução de doenças e faltas ao trabalho, resultando em ganhos consideráveis para as companhias que ocupam edifícios deste tipo. Ries e Bilec (2006), em estudo de caso realizado com uma fábrica de pré-moldados na Pensilvânia, que 
teve sua antiga sede substituída por um novo edifício sustentável, apontam que a produtividade aumentou $30 \%$ enquanto a energia usada teve um decréscimo de $25 \%$. Estudos realizados descobriram que a ausência e atraso de pessoal no trabalho ou de alunos nas escolas foi reduzida, em edifícios sustentáveis (KATS, 2003).

Um edifício sustentável pode reduzir também as demandas legais e a responsabilidade civil do proprietário e do arquiteto, pois podem ser responsabilizados por edifícios que impactam negativamente a saúde dos ocupantes (CRYER et al., 2006). Estudos de EPA indicam que os níveis de contaminantes interiores podem ser de dois a cinco vezes maiores -e, às vezes, mais de 100 vezes maiores- que os níveis exteriores. Esses níveis de contaminação são notáveis já que há uma estimativa de que grande parte das pessoas, principalmente em ambientes urbanos, passa entre 80 e $90 \%$ do seu tempo dentro de edifícios.

Os benefícios esperados do edifício sustentável de acordo com entrevistas realizadas, com pessoas com experiência (arquitetos, engenheiros, contratistas e proprietários) neste tipo de edifícios dos EUA, por McGraw Hill Construction (2005), são os seguintes:

$>\quad$ Saúde e bem-estar (88\%);

> Criação de valor da construção (84\%);

$>$ Melhorar a produtividade do trabalhador (78\%);

$>$ Retorno de investimento (ROI) (68\%);

$>$ Oferta de aluguel (61\%);

$>$ Total das vendas de bens (45\%);

> Maior taxa de ocupação (44\%).

O estudo de McGraw Hill Construction (2005) encontrou também as seguintes razões para construir edifícios sustentáveis, acompanhadas das respectivas percentagens de resposta indicadas entre parêntesis:

$>$ Reduzir os custos do ciclo de vida com a eficiência energética e aumentar a produtividade $(73 \%)$;

$>$ Fazer parte da indústria que valoriza o meio ambiente (72\%); 
> Expandir os negócios com clientes interessados em edifícios sustentáveis (53\%);

$>$ Meio de manter-se informado sobre o LEED (52\%);

$>$ Informação sobre produtos verdes (51\%);

$>$ Beneficia-se da publicidade (44\%);

> Maior ROI da revenda (33\%);

> Prêmio para o edifício sustentável (31\%).

Os resultados deste estudo indicam que os motivos mais frequentes que podem levar a construir edifícios sustentáveis são fazer parte da indústria que valoriza o meio ambiente e reduzir os custos do ciclo de vida com a eficiência energética e aumento da produtividade dos trabalhadores ocupantes do edificio. Este estudo também descobriu os benefícios mais esperados ao construir-los, que, além da produtividade, saúde e bem-estar do trabalhador, também é a atribuição de valor à construção. Estes resultados confirmam que os motivos mais frequentes para construir edifícios sustentáveis guardam relação direta com os benefícios mais esperados.

De acordo com o estudo realizado por Turner Green Building Market Barometer (2010), com 681 representantes de organizações ligadas ao mercado da construção sustentável dos EUA, os principais fatores para avaliar custos-benefícios quando se decide incorporar a sustentabilidade no projeto e na construção, acompanhados das respectivas percentagens de resposta indicada entre parêntesis, são:

$>$ Eficiência energética (88\%);

> Custos de operação e manutenção do empreendimento ( $86 \%$ );

$>$ Valor da construção (76\%);

$>$ Custo total, 10 anos (74\%);

$>$ Taxas de ocupação (74\%);

$>$ Qualidade do ar interior (72\%);

> Saúde e bem-estar dos ocupantes (72\%);

$>$ Aluguel do imóvel (71\%);

> Impacto na marca/reputação (67\%);

> Satisfação dos empregados/ocupantes (65\%);

> Uso eficiente da água (64\%); 
$>$ Produtividade dos funcionários (63\%);

$>$ Admissão do empregado/retenção (44\%).

Melhorar a eficiência energética, reduzir os custos operacionais do empreendimento e aumentar o valor da construção são provavelmente os fatores em que o futuro empreendedor mais rapidamente pensará ao analisar a possibilidade de construir um edifício sustentável.

\section{Benefícios das certificações ambientais para edifícios}

Os edifícios certificados pelo Processo AQUA podem apresentar vários benefícios para as seguintes partes interessadas, de acordo com o quadro a seguir.

Quadro 3: Principais benefícios dos edifícios certificados pelo Processo AQUA

\begin{tabular}{|c|c|}
\hline Parte interessada & Benefício \\
\hline \multirow{6}{*}{ Empreendedor } & Provar a Alta Qualidade Ambiental das suas construções \\
\hline & Diferenciar seu portfólio no mercado \\
\hline & Aumentar a velocidade de vendas ou locação \\
\hline & Manter o valor do seu patrimônio ao longo do tempo \\
\hline & Associar a imagem da empresa à Alta Qualidade Ambiental \\
\hline & Melhorar o relacionamento com órgãos ambientais e comunidades \\
\hline \multirow{5}{*}{ Comprador } & Economia direta de água e energia \\
\hline & Menores custos de condomínio - energia, água, \\
\hline & Conservação e manutenção \\
\hline & Melhores condições de conforto saúde e estética \\
\hline & Maior valor patrimonial ao longo do tempo \\
\hline \multirow{10}{*}{ Sócio-ambientais } & Menor consumo de energia \\
\hline & Menor consumo de água \\
\hline & Redução das emissões de Gases de Efeito Estufa \\
\hline & Redução da poluição \\
\hline & Melhores condições de saúde nas edificações \\
\hline & Melhor aproveitamento da infraestrutura local \\
\hline & Menor impacto na vizinhança \\
\hline & Melhores condições de trabalho \\
\hline & Redução da produção de resíduos \\
\hline & Gestão de Riscos naturais, solo, água, ar... \\
\hline
\end{tabular}

Fonte: FCAV (2012)

Um certificado de edifício sustentável pode oferecer alguma medida de proteção contra futuros processos, através da verificação feita por terceiros das iniciativas tomadas para preservar a qualidade do ar interno. Autorizações mais rápidas ou auxílios de permissão especiais também podem ser considerados um tipo de diminuição de riscos. Além disso, a certificação reduz o green washing ou a falsa imagem de responsabilidade para com o 
meio ambiente, pois fornece a verificação por terceiros das medidas tomadas para projetar e construir um edifício sustentável (CRYER et al., 2006). Os green buildings oferecem também oportunidades de redução de riscos empresariais, uma vez que existe uma grande cobrança da sociedade e mídia a respeito de questões voltadas para a sustentabilidade (PARDINI, 2009).

Outro beneficio dos edifícios sustentáveis para o gerenciamento de riscos no setor privado são a venda e locação mais rápidas quando comparadas com projetos semelhantes na mesma cidade. A rapidez para locação ou venda das salas num edifício comercial que tenha certificado depende da conscientização do comprador ou locatário, e, havendo uma diferença de valor, a disposição dele em arcar com esse custo. Uma pesquisa realizada no exterior revelou que por volta de $15 \%$ a $18 \%$ dos compradores aceitaram pagar até $5 \%$ a mais em um produto que fosse melhor ambientalmente. O mercado ainda está muito incipiente no Brasil e não é possível caracterizar uma tendência a esse respeito (SILVA, 2010). Um estudo desenvolvido pelo Heschong Mahone Group em 108 edifícios constatou que as vendas em determinadas lojas foram $40 \%$ maior quando estavam iluminados com claraboias, em vez de iluminação elétrica (LUCUIK et al., 2005). Outro estudo, feito pelo CoStar Group em 2008, revelou que edifícios sustentáveis superam - às vezes por amplas margens- edifícios convencionais semelhantes em áreas importantes, como ocupação, preço de venda e valores de locação (USGBC, 2011).

Em alguns países o Poder Público concede incentivos fiscais para a construção de green buildings e a certificação pode ser utilizada para demonstrar o desempenho ambiental. Um exemplo esta nos EUA, onde muitos estados mudaram sua legislação e por meio de incentivos e exigências de requisitos mínimos de sustentabilidade a prédios privados e públicos tornaram mais familiar às construtoras o processo de certificação (CRYER et al., 2006). Indiretamente, a demanda reduzida em energia, gás e água nos edifícios sustentáveis significa que estas infraestruturas podem "fazer mais com menos", o que pode resultar em menores custos de serviços públicos municipais em longo prazo.

As certificações ambientais de edifícios aumentam a oferta de mão de obra na mesma região do edifício, pois frequentemente promovem o uso de materiais locais e regionais que por sua vez fomenta a criação de empregos local e regional. Além disso, muitos atributos do green building requerem muita mão de obra, em vez de material ou tecnologia 
intensiva. Por exemplo, a reciclagem e a reutilização em oposição à eliminação e ao aumento de custos da consultoria (LUCUIK et al., 2005).

Tanto prédios residenciais quanto comercias mantêm um alto valor de revenda, se incorporam componentes de projeto sustentável. A percepções de aumento de lucratividade de um green building pelas empresas são distintas, segundo Pardini (2009), pois variam com o produto, a população alvo e o nível de conhecimento sobre o assunto. Algumas empresas acreditam que a lucratividade direta de vendas é em torno de 3 a 20\%, havendo mais disposição em se pagar um premium price (valor prêmio), por parte de clientes que reconhecem o valor agregado com a sustentabilidade (PARDINI, 2009). Por exemplo, de acordo com um estudo de 2007, os preços de venda ou locação de edifícios energeticamente eficientes são até $10 \%$ maiores por metro quadrado do que os edifícios convencionais (MILLER et al., 2008).

Por outro lado, a implantação das certificações ambientais é financeiramente compensadora, fazendo com que as empresas tenham, além desse beneficio direto, benefícios indiretos como o reconhecimento de sua ação e a possível valorização da sua reputação (FOSTER et al, 2000). A sustentabilidade no edifício pode ser entendida como valor, dependendo do ponto de vista da parte interessada (PARDINI, 2009). O valor dado a um empreendimento dependerá do tipo de cliente, da contribuição do edifício para a lucratividade do negócio e de razões subjetivas com imagem, identidade e outras preferências pessoais (LUTZKENDORF et al. , 2005 apud PARDINI, 2009). O valor percebido pelos compradores e locadores varia quando recebem informação dos benefícios dos edifícios sustentáveis.

Outro beneficio dos edifícios sustentáveis certificados são os ganhos em mídia gratuita (pela veiculação de materiais jornalísticos) provenientes da divulgação em imprensa especializada, reportagens ou premiação e que são de difícil mensuração. Em muitos casos, a forma distinta de conceituação de um edifício sustentável já garante um diferencial (EDWARDS, 1998) e uma maior atratividade para os clientes, que resulta em vantagem dentro do seu mercado competitivo.

Finalmente os edifícios sustentáveis certificados têm benefícios de marketing significativos quando comparados com edificações convencionais. Algumas empresas que querem 
demonstrar seu compromisso com a sustentabilidade constroem ou buscam instalar suas operações em green building (LUCUIK et al.,2005) enquanto outras que desejam promover uma imagem de "responsabilidade corporativa", podem beneficiar-se das relações públicas e da marca relacionada com green building (CRYER et al., 2006) também podem beneficiar-se com a melhoria ou a formação de uma imagem corporativa junto a seus clientes, fornecedores e colaboradores (EDWARDS, 1998). Alguns proprietários consideram os green building como um jogo de marketing, o que acontece frequentemente nas empresas da indústria pesada que ficaram historicamente conhecidas por seus efeitos nocivos ao meio ambiente (CRYER et al., 2006).

\subsubsection{AS DIFICULDADES}

Nas dificuldades serão expostos fatores que de alguma forma podem interferir negativamente para a construção dos green buildings e a adoção dos sistemas de certificação ambiental de edifícios dentro das empresas.

O levantamento das dificuldades da construção de edifícios sustentáveis e da certificação ambiental de edifícios foi efetuado com base na literatura disponível sobre o assunto onde buscou-se efetuar a sua divisão conforme a dimensão em que elas se enquadram. $\mathrm{O}$ resultado dessa divisão forma um conjunto organizado em 6 dimensões diferentes, demonstrada na quadro 4. Posteriormente estas dificuldades são divididas em relação às dificuldades para implantação/construção de edifícios sustentáveis (independentemente de ter ou não certificação) e das dificuldades próprias do processo de certificação. 


\section{Dificuldades na implementação de edifícios sustentáveis}

O estudo de Landman Show (1999) apud Da Silva (2008) identifica os principais obstáculos mais frequentes para a implementação dos green building, que são:

$>$ Falta de treinamento e educação em projeto sustentável/construção;

$>$ Falta de interesse ou demanda para a construção sustentável dos clientes (proprietários/ empreendedores);

$>$ Falha na gestão da estrutura de custos para dar conta da recuperação da poupança de longo prazo;

$>$ Alto custo (tanto o real como o percebido) das opções para construção sustentável.

Schendler e Udall (2005) citam que os problemas que fazem com que os green building sejam mais difíceis de serem alcançados são:

$>$ Alto custo (monetário, de tempo e esforço) da certificação;

$>$ Foco na obtenção de pontos para a certificação e não na responsabilidade ambiental;*

$>$ Complexidade da simulação energética requerida;

$>$ Burocracia engessada (que resulta na lentidão do processo e em montanhas de documentos); *

$>$ Desencaminhamento dos benefícios das edificações sustentáveis por permitir que apenas os requisitos desejáveis sejam atendidos (além dos pré-requisitos, obviamente) sem que o resultado final seja afetado. *

O relatório de Cryer et al. (2006) permite verificar que 30 representantes de organizações ligadas ao mercado imobiliário da cidade de Santa Monica/EUA citam que os fatores que desencorajam a decisão de desenvolver green building, acompanhados das respectivas percentagens de resposta indicados entre parêntesis, são:

> Alto custo da construção (68\%);

*São pertinentes para o LEED 
$>$ Falta de conhecimentos dos benefícios (64\%);

$>$ Documentação LEED (54\%);

$>$ Curto prazo-horizonte de orçamento (51\%);

$>$ Prazo de retorno muito longo (50\%);

$>$ Dificuldade em quantificar os benefícios (47\%);

> Maior complexidade na construção (30\%);

$>$ Aumento dos custos operacionais (26\%).

Estes mesmos respondentes apontam como potenciais obstáculos para os green building, a:

$>$ Falta de educação (52\%);

$>$ Falta de conscientização (48\%);

$>$ Diferença em orçamentos de contas (45\%);

$>$ Política (43\%);

> Percepção dos green building como um modismo (34\%);

> Maquiagem verde "greenwashing"ou falsa publicidade ambiental (17\%).

No contexto brasileiro, o estudo de Piccoli (2009) procurou conhecer os possíveis entraves ou barreiras para a aplicação e implementação de práticas sustentáveis na construção realizada junto a 25 engenheiros civis e arquitetos das cidades de São Leopoldo e Novo Hamburgo, e obteve os seguintes resultados:

$>$ Maior custo inicial (23\%);

$>$ Desinteresse por parte do mercado (19\%);

$>$ Desinformação dos profissionais (19\%);

$>$ Falhas na legislação (7\%);

> Falta de parâmetros de sustentabilidade (13\%);

> Distância entre estudos acadêmicos e práticas profissionais (19\%).

Uma das mais comuns objeções ao green building é a ideia de que custa significativamente mais do que o edifício convencional. Diversos estudos apontam o custo inicial como o principal problema encontrado quando da decisão de fazer ou não um projeto sustentável. Este ponto de vista pode ser questionado a partir do conhecimento de informações 
especificas e do desenvolvimento de diretrizes e recomendações que auxiliem aos participantes do processo a tomar decisões com conhecimento (DASILVA, 2008).

O relatório da Turner Construction (2005) apontou que 75\% dos executivos envolvidos com projetos sustentáveis sentem que tais construções possuem um custo maior do que a construção convencional sendo que as estimativas de acréscimo do custo inicial foram diferentes entre os executivos envolvidos com projetos sustentáveis e os não envolvidos, uma percepção de acréscimo de $13 \%$ e 18\%, respectivamente. Adicionalmente, os respondentes do survey referido no relatório da Turner Construction indicavam ao "alto custo inicial" como o principal obstáculo ao green building (MCGRAW HILL CONSTRUCTION, 2005). No estudo de Design e Construção de edifícios feito em 2007, $78 \%$ dos entrevistados em arquitetura, engenharia e construção acreditavam que tornar-se verde "aumenta significativamente o custo inicial" (GALAZ et al. , 2009). No estudo realizado por CoreNet Global/Jones Lang LaSalle no ano 2008, 30\% dos entrevistados acreditavam que os edifícios sustentáveis custavam de 5 a $10 \%$ mais que os edifícios convencionais, e $22 \%$ acreditavam que custavam mais de 10\% (KADZIS, 2008).

Há muitos fatores que podem impactar o custo inicial de construção de um green building, como a localização, como está integrado o processo de projeto e a quantidade de projetos green building construidos pelo empreendedor ou proprietário (CRYER et al., 2006).

Entretanto, apesar do ceticismo e dúvida a respeito do tema, existem casos reais que mostram um acréscimo mínimo de custo, ou até mesmo nenhum custo (KATS, 2003). Por exemplo, estudos de IFMA Foundation e Turner Construction mostram que os edifícios sustentáveis não chegam a custar mais de $1 \%$ que os edifícios convencionais, sendo que alguns custam menos que os edifícios convencionais (MCGRAW HILL CONSTRUCTION, 2005). Por outro lado, o estudo de Langdon (2007) observa que "não existe diferença significativa nos custos médios dos edifícios sustentáveis em comparação com os edifícios convencionais" concluindo que uma grande quantidade de projetos alcança a certificação LEED dentro de seus orçamentos e na mesma faixa de preço que os projetos convencionais.

Segundo Silva (2010), um dos obstáculos para a implementação de projetos sustentáveis seria o modelo atual de contratação, locação e venda, pois quem constrói não 
necessariamente recebe os benefícios operacionais do empreendimento. Além disso, os investidores do setor imobiliário não se sentem confortáveis em quantificar o valor de um edifício sustentável e, portanto têm resistência em assumir o risco em desenvolvê-lo devido a flutuações do mercado e a escassez de informações e projeções futuras (LAM, 2004). A maioria das incorporadoras do setor imobiliário esta financiada por mutuantes externos, que geralmente têm conhecimento insuficiente para determinar com precisão o valor de um edifício sustentável. Resultando em incorporadores preocupados em diminuir custos da construção e maximizar a área construída dentro de um cronograma de entrega com pouco incentivo para incorporar medidas da construção sustentável (LUCUIK et al.,2005).

Conforme apontam Kua; Lee (2002), tradicionalmente a indústria da construção demora em absorver novos conceitos. Em um setor conservador como o da construção civil, com pouca experiência em inovação tecnológica, a introdução de novas tecnologias, especialmente envolvendo novos materiais e processos construtivos, levam 10 a 20 anos até serem completamente aceitos e difundidos. Dentre as diversas razões por trás desta lentidão, a resistência dos construtores e investidores à tomada de riscos ligados a inovações é significativa, tendo em vista a grande quantidade de recursos que a construção de um edifício consome (LAM, 2004). Muitas vezes esta resistência está relacionada com o medo do aumento dos custos derivados da falta de antecedentes e experiência, assim como da falta de familiaridade com as tecnologias verdes necessárias para executar este tipo de edifícios. Essa inexperiência e falta de qualificação resulta em custos iniciais mais altos e na limitação para implementar o melhor conjunto de estratégias sustentáveis para produzir o melhor retorno sobre o investimento. A decisão de projetar e construir um edifício sustentável é baseada ainda em grande parte no custo inicial (CRYER et al., 2006).

A falta de conhecimento específico, de treinamento e de familiaridade de clientes, construtoras e fornecedores em relação ao entendimento das estratégias e conceitos de sustentabilidade na construção (CALKINGS, 2005; DAVIES, 2005) traz desconforto com relação a novas tecnologias, sistemas e materiais (CALKINS, 2005) e medo do aumento dos custos, o que intimida as construtoras e fornecedores, fazendo com que os arquitetos, projetistas e clientes sejam conservadores em seu uso, super dimensionando os sistemas, não os integrando na edificação como poderiam e, consequentemente, não atingindo o desempenho desejado (KATS, 2003). 
Segundo Figueiredo et al., (2010), os principais obstáculos para que os conceitos de projeto e construção sustentável sejam efetivamente implementados são: a indisponibilidade de informações confiáveis e garantia de desempenho, a incapacidade da pratica típica de projeto apoiar os esforços de otimização do projeto, fundamentais para atender metas mais agressivas de desempenho, e a implementação do processo de projeto integrado, pois se trata de uma mudança de postura substancial.

\section{Dificuldades para a obtenção da certificação ambiental de edifícios}

Relativamente às dificuldades ou barreiras encontradas na implementação da certificação LEED, os resultados do estudo de Johnson (2005), realizado nos EUA junto a 43 pessoas envolvidas em empreendimentos registrados no LEED, consideram "Mais desafiadora" ou "Muito desafiante" as principais dificuldades e barreiras, que a seguir se indicam, acompanhadas da respectiva frequência de resposta indicadas entre parêntesis:

> Custo da documentação/ outros custos indiretos (21);

$>$ Falta de experiência no LEED dos integrantes da equipe (17);

> Custos de projeto e da construção sustentável (14);

> Custo direto da certificação (13);

$>$ Proprietário incapaz de se recuperar dos aumentos nos custos (11);

$>$ Comunicação/desentendimento com o USGBC (11);

> Pobre comunicação/educação da equipe (8);

$>$ Incapacidade de se atender os pré-requisitos do LEED (4);

$>$ Os créditos não são suficientes para se qualificar (5);

$>$ Rotatividade da equipe de projeto (2).

Cooper (2002) aponta a burocracia como o maior desafio em alguns projetos LEED, referindo ainda os seguintes fatores:

$>$ Falha na comunicação;

$>$ Planejamento inadequado com os empreiteiros e subempreiteiros.

Em relação às dificuldades resultantes da adoção da certificação LEED no Brasil, Piccoli et al., (2010) destacam as seguintes: 
$>$ A implementação da certificação LEED exige muito esforço dos projetistas na introdução de especificações mais detalhadas de materiais e de memoriais mais elaborados bem como conhecimento dos quesitos solicitados pelo sistema;

$>$ Durante a fase de produção, a implementação e a aplicabilidade dos quesitos exigidos pelo sistema são bastante complexas e exigem um grande envolvimento de todas as partes, incluindo principalmente, praticas de organização do canteiro, compra de materiais e rigor na fiscalização e na documentação;

$>$ Requer novas formas de atuação dos diferentes agentes envolvidos no desenvolvimento dos empreendimentos;

$>$ Verificam a necessidade de uma abordagem sistemática do processo de gestão desses empreendimentos, envolvendo a requalificação de todos os agentes, desde os operários até a cadeia de fornecedores de materiais e componentes.

Em relação às dificuldades resultantes da obtenção da certificação no Brasil, Pardini (2009) destaca as seguintes:

$>$ Alto custo inicial dificultando a viabilidade dos green building quando da conciliação dos objetivos das partes envolvidas, como arquitetos, incorporadores, investidores e usuários;

$>$ Falta conhecimento e parâmetros para ter como experiência inicial;

$>$ Adequação às normas internacionais, uma vez que as certificações foram desenvolvidas em outros países com realidade, necessidades e prioridades diferentes das encontradas no território brasileiro;

$>$ Dificuldade em encontrar fornecedores de materiais e soluções tecnológicas para atender aos requisitos de certificação;

$>$ Dificuldade de encontrar pessoas aptas a participar deste processo, sejam elas projetistas, empreiteiros ou pessoas que componham as equipe de obra.

Alguns estudos mostram que a certificação LEED pode ser obtida com pouco ou nenhum custo. O estudo de Green Building Finance Consortium analisou o investimento em edifícios sustentáveis para estimar valores de aumento dos custos associados a diferentes níveis de certificação LEED (SUSTENTARE, 2009). Deste estudo verificou-se que: 
$>$ o menor nível de certificação LEED está associado a um custo inicial mais elevado $0,8 \%$;

$>$ edifícios certificados com o LEED Prata custarão mais 3,5\% inicialmente;

$>$ em edifícios LEED Ouro o custo inicial será 4,5\% superior e

$>$ no caso de edifícios LEED Platina os custos iniciais podem chegar a ser 11,5\% superiores.

Relativamente às dificuldades encontradas na implementação do Processo AQUA, em dois empreendimentos (loja de varejo e edifício de escritórios), os entrevistados indicaram (2 consultores do Processo AQUA e 1 empreendedor), no estudo de Rodrigo e Cardoso (2010), as seguintes dificuldades:

$>$ Precisa de especialidades de projeto pouco usuais em processos de projeto convencional (acústica, luminotécnica associada à gestão de energia, gestão de resíduos, reuso de água, simulações de desempenho energético, estudo do fator de luz do dia, estudo de luz e sombra, consultor do Processo AQUA);

$>$ Resistência de alguns dos projetistas às solicitações do Processo AQUA;

$>$ Requer de esforço por parte dos projetistas para atender aos critérios solicitados;

$>$ A construtora não possuía embasamento suficiente para atender aos requisitos da categoria 3 (canteiro de obras) e também não aceitava implantar efetivamente as exigências, para cumprir o cronograma de entrega;

$>$ Entender as exigências como uma "burocracia a mais e fichas a serem preenchidas" sem trata-las com a seriedade devida;

$>$ Exige uma gestão bastante ativa por parte do empreendedor;

$>$ Dificuldade em trabalhar com o concreto de agregados reciclados, optando por não utiliza-los em peças estruturais;

$>$ Declarações de legalidade trabalhista e outros documentos exigidos pelo processo de certificação;

$>$ Fornecedores ou sub-contratatdo não estão preparados para atender as exigências e o trabalho para ensina-los e solicitar que sejam cumpridas é grande; 
$>$ O valor agregado do ponto de vista econômico pode ser medido apenas pelas contas de água e energia, pois não há medida para outros indicadores, por exemplo, como para o valor agregado pela gestão do lixo, pelo conforto ambiental e para nenhum dos outros critérios;

$>$ Não esta clara a importância do SGE para os empreendedores;

$>$ Muito trabalho de busca e de pesquisa para desenvolver soluções;

$>$ A busca de soluções criativas para os confortos térmicos, acústico e lumínico ainda é limitada e pouco explorada.

O custo da documentação depende da complexidade do projeto e de como a equipe compartilha eficazmente os documentos. $\mathrm{O}$ custo da documentação pode ser maior quando falta experiência da equipe em processo de certificação e porque exige uma quantidade significativa de documentação do projeto. Segundo USGBC o processo de registro e documentação pode compreender uma proporção significativa dos custos totais, sobretudo para projetos com orçamentos inferiores a U\$S 5 milhões.

O custo de projetar e construir um edifício certificado com o LEED é, muitas vezes, superior por várias razões. O aumento no custo pode vir do tempo adicional necessário para investigar e planejar, o qual é monetarizado, pois o processo de certificação e os princípios de construção sustentável podem não ser bem compreendidos pelos profissionais da empresa responsáveis pela concepção do projeto (SILVA, 2010; CAPUZZI, 2010). Alguns dos pontos de certificação LEED podem, eventualmente, levar a mal entendidos entre a equipe de concepção/projeto, a equipe de construção e o cliente final o que muitas vezes resulta em atrasos em todo o processo de construção do edifício. Além disso, pode haver uma lacuna na disponibilidade de componentes e produtos (concordantes com os requisitos do LEED) necessários à construção de um edifício sustentável (SUSTENTARE, 2009). Na maioria dos casos, interfere menos o custo de construção e muito mais aqueles associados a eventuais impactos sobre o cronograma de entrega porque as certificações podem eventualmente demandar alguns cuidados durante a obra que vai acarretar atrasos no cronograma da entrada em operação do edifício (SILVA, 2010).

O custo para alcançar a certificação ambiental para edifícios, em estudos que abordam a certificação LEED, pode depender de muitos fatores indicados no quadro 5. 
Quadro 5: Possíveis fatores que influem no custo inicial devido à certificação

\begin{tabular}{|c|c|}
\hline Fatores & Autor \\
\hline Tipo e tamanho do projeto & \multirow{7}{*}{ Syphers et al., (2003) } \\
\hline Tempo para adoção do LEED como um objetivo ou exigência & \\
\hline Nível de certificação LEED almejado & \\
\hline Experiência e conhecimento dos projetistas e empreiteiros & \\
\hline Processo utilizado para selecionar os créditos LEED & \\
\hline $\begin{array}{l}\text { A clareza da documentação relativa à execução do projeto e as hipóteses } \\
\text { orçamentárias baseada em cenários }\end{array}$ & \\
\hline Pressupostos orçamentais de base & \\
\hline $\begin{array}{l}\text { Exige maior dedicação e esforços de projeto, construção, seleção de } \\
\text { fornecedores, simulações, acompanhamento }\end{array}$ & \multirow{3}{*}{ Silva $(2010)$} \\
\hline Maior gasto com projetistas, consultoria, simulação & \\
\hline $\begin{array}{l}\text { Formação de um banco de fornecedores de materiais diferentes de uma } \\
\text { construção tradicional }\end{array}$ & \\
\hline Das despesas relacionadas com as deslocações dos consultores LEED & \multirow{3}{*}{ Sustentare (2009) } \\
\hline $\begin{array}{l}\text { A entrada do processo de certificação no USGBC (taxa de registro do } \\
\text { projeto) }\end{array}$ & \\
\hline A contratação de uma autoridade de comissionamento (ou gestão) & \\
\hline $\begin{array}{l}\text { A modelagem de energia que envolve a realização de simulações e analise } \\
\text { de energia de todo o projeto do edifício }\end{array}$ & Mapp et al. (2011) \\
\hline
\end{tabular}

Segundo Da Silva (2008), as boas habilidades da equipe de projeto em gerenciar os fatores mencionados por Syphers et al., (2003), invariavelmente, afetam a severidade do impacto no custo do projeto. No entanto, muitos profissionais do setor opinam que através da gestão dessas variáveis desde a concepção do projeto, um edifício certificado LEED pode ser projetado e construído com custos comparáveis a de edifícios convencionais.

Nos EUA um projeto sustentável desenvolvido baseado na certificação LEED em relação a um projeto convencional implica um aumento de $0,6 \%$ do custo no menor nível, $2 \%$ do custo no nível prata ou ouro e 6.0\% adicional para projetos platina (KATS, 2003). Alguns críticos consideram que os custos da certificação LEED exigem montantes que limitam os interessados na certificação, além disso, os custos de conformidade e certificação têm crescido mais rapidamente do que o pessoal de apoio do USGBC (SUSTENTARE, 2009).

Segundo Pardini et al., (2010) buscar a certificação implica mudança de rotina, comprometimento e acréscimo de trabalho para todos os envolvidos com o empreendimento, desde os arquitetos e projetistas até os fornecedores e subcontratados para execução de serviços. Por outro lado, Piccoli et al., (2010), consideram que a certificação LEED pode ser um processo lento e oneroso, tanto para o empreendedor quanto para a construtora, uma vez que exige uma quantidade significativa de 
documentação, vários ensaios (analises, simulações e testes) de materiais e reuniões de trabalho com a participação do proprietário, engenheiros, construtora, empresa fiscalizadora, profissional responsável pela certificação LEED, fornecedores e projetista. Schaufelberger e Cloud (2009), através de um survey com construtores que construíram 22 edifícios em 10 estados dos EUA, identificaram que 16 respondentes avaliaram o processo de certificação LEED como ligeiramente difícil e que 14 respondentes acharam que é muito longo o tempo adicional necessário para preparar a documentação LEED.

Para Ceotto (2010) apud Téchne (2010), a principal dificuldade enfrentada no processo de certificação é encontrar profissionais capacitados para fazer simulações de desempenho energético dos prédios em softwares especiais. Alguns softwares são sofisticados e outros bem simples, mas é necessária a capacitação dos profissionais para inserir corretamente os dados no programa e obter resultados confiáveis. Outra dificuldade para a adoção das certificações está na escassez de materiais, pois o mercado brasileiro de materiais "verdes" para a construção ainda está em seus primórdios, quando o comparamos ao mercado dos Estados Unidos, Austrália, Japão e União Europeia ${ }^{6}$ (BENITE, 2010).

Finalmente a falta de conhecimento e de comprometimento da construtora com a certificação é considerada também uns dos fatores que dificultam o processo de certificação. Por exemplo, a gestão de canteiro é uma atividade que exige treinamento da mão de obra e constante fiscalização (PICCOLI et al., 2010).

\footnotetext{
${ }^{6}$ Nestes paises, existe uma diversidade de Selos Verdes e etiquetagens que comprovam as características ambientais dos materiais por meio de ensaios e avaliações criteriosas, realizados por entidades de terceira parte, que dão credibilidade às informações fornecidas pelos fabricantes e minimizam o greenwashing (BENITE, 2010).
} 


\subsection{MÉTODO DE PESQUISA}

O método de pesquisa que se apresentou mais adequado para o objetivo proposto e para viabilizar a coleta de dados foi o levantamento tipo Survey. Este procedimento para coleta de dados primários é adequado à obtenção de informações acerca de comportamento, crenças, opiniões e atitudes a partir de indivíduos. Entre as vantagens deste método, está a possibilidade de se coletar informações de uma grande amostra da população em estudo e conseguir descrever as características desta (SALANT e DILLMAN, 1994). Além disso, permite o conhecimento direto da realidade, é de fácil quantificação, econômico e rápido (GIL, 2007).

\subsection{ETAPAS DA PESQUISA}

A presente pesquisa foi delineada e desenvolvida de acordo com as etapas descritas na figura 4:

Figura 4: Delineamento das etapas de pesquisa

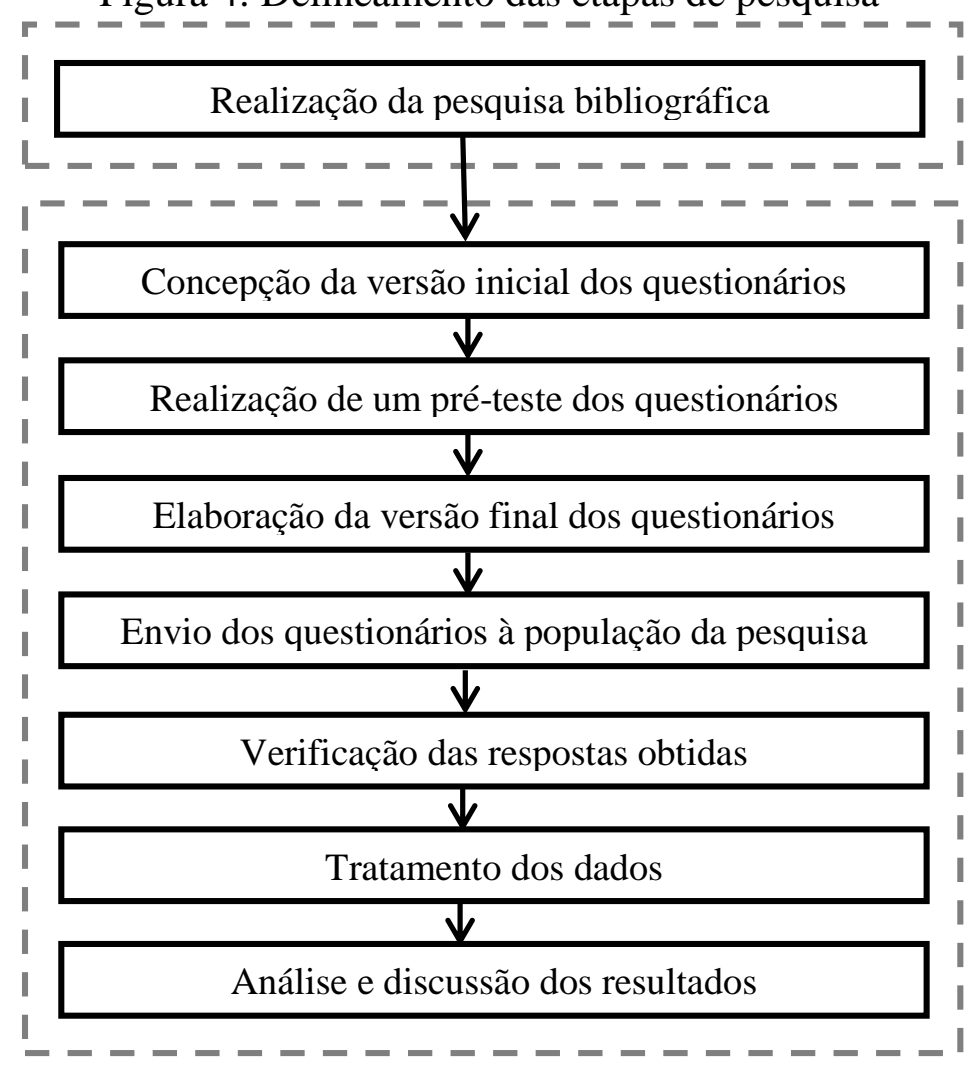


De acordo com a Figura 4, a realização do trabalho foi dividido em duas etapas. A primeira etapa consistiu na realização da pesquisa bibliográfica e consolidação de um estado de arte sobre o tema abordado e a segunda etapa no levantamento tipo Survey que serão melhor abordadas nas subseções a seguir.

\subsubsection{ETAPA 1: PESQUISA BIBLIOGRÁFICA}

Inicialmente, foi realizada a pesquisa bibliográfica exploratória, a partir do levantamento de livros, trabalhos científicos como teses e dissertações, artigos em anais de congressos e periódicos nacionais e internacionais, nas bases de dados como: Dedalus- Biblioteca da USP-, Scopus, Science Direct e Google Acadêmico.

Posteriormente, foram definidas as principais palavras-chaves utilizadas para se realizar as buscas, como: green building, sistemas de avaliação ambiental para edifícios, certificação LEED, Processo AQUA, motivações, benefícios e dificuldades dos sistemas de avaliação ambiental para edifícios. Além disso, foram pesquisados de forma complementar outros temas a fim de abranger o objeto de estudo de forma mais ampla e geral, tais como custos, redução de riscos, conforto, produtividade, imagem, processo de projeto, entre outras.

Foram encontrados muitos trabalhos internacionais sobre motivações, benefícios e dificuldades da adoção da certificação LEED, mas sobre o tema especifico motivações e dificuldades da adoção do Processo AQUA, o número de trabalhos encontrados foi menor, dado que trata-se de um protocolo nacional e mais novo. Também foram realizadas pesquisas sobre o tema na Internet, na qual foi possível ter acesso a informações da certificação LEED e do Processo AQUA através dos sites das organizações FCAV e GBC Brasil.

Cabe ressaltar que esta pesquisa bibliográfica foi realizada durante todo o desenvolvimento do trabalho, tanto a principio, para se delinear o estado da arte do tema escolhido e permitir a preparação da pesquisa descritiva, quanto no transcurso do trabalho, através de leituras mais criticas para responder os questionamentos encontrados.

\subsubsection{ETAPA 2: LEVANTAMENTO TIPO SURVEY}

A etapa 2 do presente trabalho é caracterizada como uma pesquisa quantitativa. Segundo Gil (2007) um levantamento tipo Survey compreende uma coleta de dados em uma amostra 
significativa, acerca do problema estudado, para em seguida mediante uma análise quantitativa, obterem-se as conclusões correspondentes aos dados coletados.

Para esta pesquisa foi definido como instrumento de coleta de dados o questionário. As versões iniciais dos seis questionários foram elaboradas tomando como principal fonte de informação pesquisas similares internacionais e o resultado da pesquisa bibliográfica reunida em ligação com os objetivos da pesquisa estabelecidos inicialmente.

A versão inicial de um dos questionários formulado no Google Docs foi testada durante o mês de Abril de 2011 com a intenção de identificar possíveis falhas de acesso e dificuldades no seu entendimento e preenchimento. O pré-teste consistiu no envio de uma versão inicial a dois professores da USP do Programa de Pós-Graduação em Arquitetura e Urbanismo. Como resultado verificou-se que não houve falhas e procedeu-se, então, à elaboração da versão final. Os 4 questionários, bem como a carta de apresentação da pesquisa e solicitação de colaboração,encontram-se no Anexo A.

Os questionários finais formulados em Google Docs $^{7}$ foram enviados através de links em correios eletrônicos, a toda a população da pesquisa.

\section{> QUESTIONÁRIOS DO SURVEY}

Os 4 questionários continham questões especificas para os:

1) Empreendedores ou responsáveis do Processo AQUA;

2) Empreendedores ou responsáveis da certificação LEED;

3) Profissionais LEED AP;

4) Consultores AQUA;

\footnotetext{
${ }^{7}$ As vantagens do uso desta ferramenta são as seguintes: agiliza o processo de preenchimento, rapidez na aplicação, o acesso ao questionário é mediante um link, automatização do questionário e verificação de respostas, tabulação dos resultados facilitada, entre outras.

As limitações dos questionários eletrônicos são as seguintes: baixo controle da amostra, acesso a Internet limitado, não representatividade dos resultados, alto nível educacional em informática, baixa taxa de resposta, dificuldade de recrutar participantes, formatação limitada, preocupações com vírus, possível invasão da privacidade, inclusão de explicações detalhadas, dificuldade de incluir incentivos para envio da resposta, entre outras (VASCONCELLOS et al., 2007).
} 
Os questionários 1 a 4, que serviram de base para a coleta de dados do Survey, estão constituídos por oito blocos temáticos, contendo perguntas especificas para cada grupo de respondentes, sendo eles:

$>$ Bloco 1- Dados do respondente;

$>$ Bloco 2- Dados do empreendimento;

> Bloco 3- Porque a certificação (motivações);

> Bloco 4- Ganhos da certificação (benefícios);

> Bloco 5- Processo de certificação;

> Bloco 6- Limitações da certificação (dificuldades);

> Bloco 7- Evolução da certificação;

> Bloco 8 - Sugestões e comentários sobre o questionário respondido.

Com relação às opções de respostas utilizadas nos questionários foram adotadas as duas opções propostas pela literatura (MARCONI et al., 1982): 1) respostas abertas; e 2) respostas fechadas. Para as respostas fechadas foram utilizadas as escalas nominais, ordinais, intervalares e de Likert (MARCONI et al., 1982).

\section{> COMPOSIÇÃO DA POPULAÇÃO DA PESQUISA}

$\mathrm{Na}$ fase de definição da população da pesquisa para a realização do Survey, foram considerados os empreendimentos certificados e em processo de certificação com os sistemas de avaliação ambiental de edifícios LEED e Processo AQUA. A escolha dessa população foi motivada pelo fato de que são os dois sistemas de avaliação ambiental de edifícios com mais empreendimentos certificados e em processo de certificação no Brasil no momento do delineamento da pesquisa.

A relação dos empreendimentos foi obtida através dos sites das organizações GBC Brasil e da FCAV. A tabela 1, a seguir, apresenta esses dados. 
Tabela 1: Número de empreendimentos certificados e em processo de certificação

\begin{tabular}{|c|c|c|c|}
\hline Certificação & $\begin{array}{c}\text { Empreendimentos } \\
\text { certificados }\end{array}$ & $\begin{array}{c}\text { Processos } \\
\text { iniciados }\end{array}$ & Total \\
\hline LEED & 43 & 399 & 442 \\
\hline Processo AQUA & 1 & 29 & 30 \\
\hline
\end{tabular}

Fonte: GBC Brasil,2012 e FCAV,2011

Observa-se, a partir da tabela 1, que existem 442 empreendimentos certificados e em processo de certificação com a certificação LEED e 30 empreendimentos certificados e em processo de certificação com o Processo AQUA.

De posse dessa relação dos empreendimentos uma base de dados foi criada com as seguintes informações: 1) proprietário ou empreendedor; 2) escritório de arquitetura; 3) consultores. As fontes de informação para a realização desta base de dados foram os sites da organização GBC Brasil e da FCAV e a Internet.

Essa escolha foi motivada pelo fato de cada um deles estar envolvidos em diferentes momentos das fases de projeto, produção e ocupação. Cada um tem opiniões, conhecimentos e motivações diferentes, além de distintas percepções dos benefícios e dificuldades do desenrolar e da ocupação dos empreendimentos certificados pelos sistemas de avaliação ambiental LEED e Processo AQUA.

Para identificar a população da pesquisa se realizaram três etapas:

$>$ ETAPA1: Identificação das empresas;

> ETAPA2: Identificação dos dados complementares dessas empresas;

$>$ ETAPA3: Contato telefônico com as empresas.

A seguir, é relatado e explicado como foi desenvolvida cada etapa.

\section{ETAPA 1: IDENTIFICAÇÃO DAS EMPRESAS}

\section{CERTIFICAÇÃO LEED}

\section{a) Empresa proprietária}

Com base nos dados disponibilizados no site da organização GBC Brasil foi possível identificar a quantidade de empresas proprietárias. Para isso, primeiramente, foram 
eliminados os empreendimentos que tinham dados confidenciais sobre os nomes do proprietário ou empreendimentos, sobrando 242 empreendimentos. Posteriormente, se identificaram as empresas proprietárias que detêm mais de um empreendimento certificado ou em processo de certificação. As tabelas 2 e 3, a seguir, apresentam as quantidades de empresas proprietárias que detêm mais de um empreendimento certificado e em processo de certificação.

Tabela 2: Empresas proprietárias e empreendimentos certificados LEED

\begin{tabular}{|c|c|}
\hline Empresas proprietárias & $\begin{array}{c}\text { Número de empreendimentos da } \\
\text { empresa certificados LEED }\end{array}$ \\
\hline E1 & 2 \\
\hline E2 & 2 \\
\hline E3 & 4 \\
\hline E4 & 3 \\
\hline E5 & 2 \\
\hline E6 & 1 \\
\hline E7 & 2 \\
\hline E8 & 1 \\
\hline E9 & 1 \\
\hline Numero total de empresas:9 & Numero total de empreendimentos:15 \\
\hline
\end{tabular}

Portanto, o universo de pesquisa dentre as empresas proprietárias com empreendimentos certificados LEED é de 15. 
Tabela 3: Empresas proprietárias com empreendimentos em processo de certificação LEED até 01/03/2012

\begin{tabular}{|c|c|}
\hline Empresas proprietárias & $\begin{array}{c}\text { Número de empreendimentos da } \\
\text { empresa em processo de certificação } \\
\text { LEED }\end{array}$ \\
\hline E1 & 3 \\
\hline E2 & 3 \\
\hline E3 & 3 \\
\hline E4 & 1 \\
\hline E5 & 0 \\
\hline E6 & 4 \\
\hline E7 & 1 \\
\hline E8 & 4 \\
\hline E9 & 1 \\
\hline E10 & 2 \\
\hline E11 & 2 \\
\hline E12 & 2 \\
\hline E13 & 3 \\
\hline E14 & 2 \\
\hline E15 & 3 \\
\hline E16 & 4 \\
\hline E17 & 2 \\
\hline E18 & 2 \\
\hline E19 & 2 \\
\hline E20 & 2 \\
\hline E21 & 8 \\
\hline E22 & 4 \\
\hline E23 & 3 \\
\hline E24 & 3 \\
\hline E25 & 4 \\
\hline E26 & 4 \\
\hline E27 & 2 \\
\hline E28 & 3 \\
\hline E29 & 6 \\
\hline E30 & 3 \\
\hline E31 & 2 \\
\hline E32 & 2 \\
\hline E33 & 2 \\
\hline E34 & 2 \\
\hline Número total de empresas:34 & Número total de empreendimentos:91 \\
\hline
\end{tabular}

*Observação: As empresas E1 até E9 são as mesmas da tabela 2. 
Observa-se, a partir das tabelas 2, e 3 que:

$>6$ empresas proprietárias têm mais de um empreendimento certificado, somando um total de 15 empreendimentos nesta situação;

$>30$ empresas proprietárias têm mais de um empreendimento em processo de certificação, somando um total de 91 empreendimentos nesta situação;

$>9$ empresas proprietárias têm empreendimentos certificados e em processo de certificação LEED.

A tabela 4, a seguir, apresenta o número total de empreendimentos, segundo o número de empresas proprietárias.

Tabela 4: Composição do universo de pesquisa junto às empresas proprietárias (empreendedor)

\begin{tabular}{|c|c|c|c|c|}
\hline Certificação & $\begin{array}{c}\text { Empreendimentos } \\
\text { certificados em } \\
\text { processo de } \\
\text { certificação }\end{array}$ & $\begin{array}{c}\text { Empreendimentos } \\
\text { com dados } \\
\text { confidenciais } \\
\text { (excluídos) }\end{array}$ & $\begin{array}{c}\text { Distintos } \\
\text { empreendimentos } \\
\text { da mesma } \\
\text { empresa } \\
\text { proprietária }\end{array}$ & $\begin{array}{c}\text { Universo total } \\
\text { de pesquisa } \\
\text { empreendedores }\end{array}$ \\
\hline LEED & 442 & 200 & 106 & 136 \\
\hline
\end{tabular}

Assim, o número total do universo de pesquisa junto aos empreendedores partiu da subtração do número total de empreendimentos, dos que têm dados confidencias e dos que têm a mesma empresa proprietária resultando numa amostra de 136 empreendedores declarados com um ou mais empreendimentos certificados ou em processo de certificação LEED.

\section{b) Professional LEED AP e empresas de consultoria}

Segundo informações do GBC Brasil havia 152 Profissionais LEED AP no Brasil até 31 de Janeiro 2012, sendo 100 LEED AP's e 52 LEED GA's (GBC Brasil, 2012). O GBC Brasil, em seu ambiente virtual, disponibiliza, por nome, os e-mails de 53 profissionais LEED AP, mas não indicam se já trabalharam ou não na certificação de algum empreendimento. $\mathrm{O}$ site do GBC Brasil, também disponibiliza, os nomes das 19 empresas de consultoria e alguns de seus empreendimentos. A tabela 5, a seguir, apresenta a quantidade de empreendimentos em que atuou cada empresa de consultoria. 
Tabela 5: Empresas proprietárias e empreendimentos certificados LEED

\begin{tabular}{|c|c|}
\hline Empresa de consultoria & $\begin{array}{c}\text { Número de empreendimentos LEED da } \\
\text { empresa de consultoria }\end{array}$ \\
\hline $\mathrm{C} 1$ & 18 \\
\hline $\mathrm{C} 2$ & 11 \\
\hline $\mathrm{C} 4$ & 5 \\
\hline $\mathrm{C} 8$ & 2 \\
\hline $\mathrm{C} 12$ & 1 \\
\hline Número total de empresas:5 & Número total de empreendimentos:37 \\
\hline
\end{tabular}

Tabela 6: Empresas proprietárias e empreendimentos em processo de certificação LEED

\begin{tabular}{|c|c|}
\hline Empresa de consultoria & $\begin{array}{c}\text { Número de empreendimentos LEED da } \\
\text { empresa de consultoria }\end{array}$ \\
\hline C1 & 115 \\
\hline C2 & 21 \\
\hline C3 & 3 \\
\hline C4 & 8 \\
\hline C5 & 5 \\
\hline C6 & 4 \\
\hline C7 & 13 \\
\hline C $~$ & 5 \\
\hline C9 & 7 \\
\hline C10 & 2 \\
\hline C11 & 2 \\
\hline C12 & 1 \\
\hline Número total de empresas: 12 & Número total de empreendimentos: 185 \\
\hline
\end{tabular}

A tabela 7, a seguir, apresenta o número total de empreendimentos, segundo o número de empresas consultoria.

Tabela 7: Composição do universo de pesquisa junto às empresa de consultoria

\begin{tabular}{|c|c|c|c|}
\hline Certificação & $\begin{array}{c}\text { Total de empresas } \\
\text { de consultoria }\end{array}$ & $\begin{array}{c}\text { Empresa de } \\
\text { consultoria de } \\
\text { repetidas por } \\
\text { empreendimento }\end{array}$ & $\begin{array}{c}\text { Universo total } \\
\text { de pesquisa } \\
\text { empresa de } \\
\text { consultoria }\end{array}$ \\
\hline LEED & 19 & 7 & 12 \\
\hline
\end{tabular}

Por tanto o universo de pesquisa dentre as empresas que prestam consultoria a empreendimentos LEED é de 12. 


\section{PROCESSO AQUA}

\section{a) Empresa proprietária}

A FCAV em seu ambiente virtual disponibiliza por empreendimento os nomes das empresas proprietárias e dos responsáveis do projeto. Até outubro de 2011, havia 1 empreendimento que recebeu a certificação nas três etapas e 29 com processos iniciados. Desses 30 empreendimentos 2 tinham dados confidenciais sobre o nome do proprietário, sobrando 28. Desses 28, se identificaram as empresas proprietárias que tinham mais de um empreendimento certificado ou com processo iniciado, restando 25. As tabelas 8 e 9, a seguir, apresentam as quantidades de empresas proprietárias que detém mais de um empreendimento.

Tabela 8: Empresas proprietárias e empreendimentos certificados pelo Processo AQUA

\begin{tabular}{|c|c|}
\hline Empresas proprietárias & $\begin{array}{c}\text { Número de empreendimentos da } \\
\text { empresa certificados pelo processo } \\
\text { AQUA }\end{array}$ \\
\hline E1 & 1 \\
\hline Número total de empresas: 1 & Número total de empreendimentos:1 \\
\hline
\end{tabular}

Tabela 9: Empresas proprietárias e empreendimentos com processos iniciados pelo Processo AQUA

\begin{tabular}{|c|c|}
\hline Empresas proprietárias & $\begin{array}{c}\text { Número de empreendimentos da } \\
\text { empresa com processos iniciados pelo } \\
\text { processo AQUA }\end{array}$ \\
\hline E1 & 6 \\
\hline E2 & 4 \\
\hline E3 & 2 \\
\hline Número total de empresas:3 & Número total de empreendimentos:12 \\
\hline
\end{tabular}

Observa-se, a partir das tabelas 8 e 9 que:

$>1$ empresa proprietária tem um empreendimento certificado nas três etapas;

$>3$ empresas proprietárias têm mais de um empreendimento com processos iniciados, somando um total de 12 empreendimentos nesta situação; 
$>1$ empresa proprietária tem 1 empreendimento certificado nas três etapas e 6 com processos iniciados.

\section{b) Empresas de consultoría}

Para identificar os nomes das empresas de consultoria, foram realizadas buscas dos empreendimentos através da internet com a intenção de pesquisar os nomes das empresas que lhes fazem consultoria. Foi dessas buscas que foram localizados os nomes de 3 empresas.

\section{CÁLCULO DA AMOSTRA}

O cálculo da amostra foi realizado através da seguinte formula:

$$
n=\frac{Z^{2} \cdot p(1-p) \cdot N}{(N-1) \cdot \varepsilon^{2}+Z^{2} \cdot(p \cdot(1-p))}
$$

Onde: $\mathrm{N}$ é o $\mathrm{n}^{\mathrm{o}}$ de pessoas da amostra, $\mathrm{Z}$ é uma constante igual a 1,96 que representa o valor da distribuição normal padrão para o nível de confiança de 95\% , N é o tamanho da população, $\varepsilon(10 \%)$ é o erro máximo de estimação e p $(50 \%)$ a proporção de respondentes.

Tabela 10: Estatísticas preliminares referentes aos grupos de empresas a serem estudados

\begin{tabular}{|l|c|c|}
\hline Grupo segundo o respondente & $\begin{array}{c}\text { Número } \\
\text { aproximado de } \\
\text { empresas na } \\
\text { população }\end{array}$ & $\begin{array}{c}\text { Número esperado de } \\
\text { empresas na amostra }\end{array}$ \\
\hline $\begin{array}{l}\text { Empreendedores ou responsáveis do } \\
\text { Processo AQUA }\end{array}$ & 28 & 11 \\
\hline $\begin{array}{l}\text { Empreendedores ou responsáveis da } \\
\text { certificação LEED }\end{array}$ & 136 & 56 \\
\hline Profissionais LEED AP & 53 & 34 \\
\hline Empresas de consultoria do LEED & 12 & 3 \\
\hline Consultores AQUA & 3 & 11 \\
\hline
\end{tabular}




\section{ETAPA 2: IDENTIFICAÇÃO DOS DADOS COMPLEMENTARES DESSAS EMPRESAS}

A tabela 11, a seguir, apresenta as informações sobre a população da pesquisa após a segunda etapa que foi a identificação de dados complementares (número de telefone e emails) da base de dados.

Tabela 11: Definição da população da pesquisa da pesquisa da base de dados

\begin{tabular}{|c|c|c|}
\hline \multirow{2}{*}{ Certificação } & \multicolumn{2}{|c|}{ ETAPA 2 } \\
\cline { 2 - 3 } & $\begin{array}{c}\text { Proprietários ou } \\
\text { responsáveis }\end{array}$ & Consultores \\
\hline LEED & 136 & 53 \\
\hline $\begin{array}{c}\text { Processo } \\
\text { AQUA }\end{array}$ & 28 & 3 \\
\hline
\end{tabular}

Percebe-se, ao analisar a tabela 11, uma quantidade reduzida de empresas na população da pesquisa. A primeira dificuldade foi a identificação do número de telefone dos proprietários ou responsáveis, encontrados. Primeiramente foi feito um contato com a FCAV e o GBC Brasil, sendo fornecidos alguns dados, mas não os números de telefone e os e-mails que faltavam. Posteriormente, foram realizadas buscas através da internet em sites das empresas proprietárias e de escritórios de arquitetura, além de sites dos empreendimentos. Este trabalho inicialmente foi desenvolvido entre os meses de Abril e Março de 2011, para ser retomado em Março de 2012.

\section{$>$ REALIZAÇÃO DO SURVEY}

\section{ETAPA 3: CONTATO TELEFÔNICO COM AS EMPRESAS}

As tabelas 12 e 13 a seguir, apresentam as informações sobre a população da pesquisa após a realização da terceira etapa, que consistiu no contato telefônico com os proprietários ou responsáveis e consultores. 
Tabela 12: Definição da população da pesquisa da base de dados envolvendo proprietários ou responsáveis até março de 2012

\begin{tabular}{|c|c|c|c|}
\hline Certificação & $\begin{array}{c}\text { Número de } \\
\text { proprietários ou } \\
\text { responsáveis } \\
\text { ETAPA 1 }\end{array}$ & $\begin{array}{c}\text { Número de } \\
\text { proprietários ou } \\
\text { responsáveis } \\
\text { APÓS ETAPA 2 }\end{array}$ & $\begin{array}{c}\text { Número de } \\
\text { proprietários ou } \\
\text { responsáveis } \\
\text { APÓS ETAPA 3 }\end{array}$ \\
\hline LEED & 136 & 118 & 92 \\
\hline $\begin{array}{c}\text { Processo } \\
\text { AQUA }\end{array}$ & 28 & 27 & 14 \\
\hline
\end{tabular}

Tabela 13: Definição da população da pesquisa da base de dados envolvendo consultores até março de 2012

\begin{tabular}{|c|c|c|c|}
\hline Certificação & $\begin{array}{c}\text { Número de } \\
\text { consultores } \\
\text { ETAPA 1 }\end{array}$ & $\begin{array}{c}\text { Número de } \\
\text { consultores } \\
\text { APÓS ETAPA 2 }\end{array}$ & $\begin{array}{c}\text { Número de } \\
\text { consultores } \\
\text { APÓS ETAPA 3 }\end{array}$ \\
\hline LEED & 53 & 53 & 53 \\
\hline $\begin{array}{c}\text { Processo } \\
\text { AQUA }\end{array}$ & 3 & 3 & 3 \\
\hline
\end{tabular}

A transição entre as etapas 2 e 3 aconteceu da seguinte maneira. O contato inicial foi feito por telefone, para a identificação da pessoa adequada para responder o questionário, que neste caso, foram os proprietários ou responsáveis e consultores. Esta etapa foi realizada durante os meses de Outubro e Novembro de 2011 e foi retomada em Março de 2012.

Foram eliminadas empresas que não aceitaram participar da pesquisa. Dentre as que não aceitaram participar, observou-se três grupos: as que declararam explicitamente não querer participar por falta de tempo, aquelas em que a política interna da empresa não permite fornecer esse tipo de informação, e as que alegaram não ter ninguém responsável sobre o assunto, o que impossibilitaria a participação.

Nesse sentido, o tamanho da população foi definido pelo número de empresas que aceitaram participar da pesquisa. Se mais empresas tivessem aceitado, mais empresas poderiam ter respondido os questionários, e quanto maior número, maior seria o poder de inferência da pesquisa.

Uma vez feito o contato telefônico com a empresa, foi feita a apresentação da pesquisadora, da instituição de ensino e da pesquisa. Posteriormente, foi solicitado um contato com o profissional responsável em questão. Quando o profissional encontrava-se na empresa a pesquisa e seus objetivos eram apresentados novamente e a pessoa era 
questionada se gostaria de participar. Em caso, afirmativo era solicitado o endereço eletrônico da pessoa para que o questionário pudesse ser enviado.

Quando o profissional não era localizado, era solicitado, também, o endereço eletrônico dele para um posterior contato e envio do questionário. Com o intuito de aumentar a taxa de retorno dos questionários, os e-mails foram enviados novamente para os proprietários ou responsáveis, consultores, que ainda não tinham respondido. Isso aconteceu uma vez no mês de outubro, uma no mês de novembro e duas vezes no mês de março. A tabela 14 apresenta a taxa de retorno dos questionários.

Tabela 14: Taxa de retorno da pesquisa

\begin{tabular}{|c|c|c|c|c|}
\hline \multirow{2}{*}{ Certificação } & $\begin{array}{c}\text { Proprietários } \\
\text { ou } \\
\text { responsáveis }\end{array}$ & Consultores & $\begin{array}{c}\text { Proprietário } \\
\text { s ou } \\
\text { responsávei } \\
\text { s }\end{array}$ & Consultores \\
\cline { 2 - 5 } & \multicolumn{2}{|c|}{ Questionários enviados } & \multicolumn{2}{|c|}{ Questionários respondidos } \\
\hline LEED & 92 & 53 & 7 & 8 \\
\hline $\begin{array}{c}\text { Processo } \\
\text { AQUA }\end{array}$ & 14 & 3 & 3 & 1 \\
\hline
\end{tabular}

Foram completadas mais de 157 ligações telefônicas, e trocados mais de 170 e-mails entre Outubro de 2011 e Março de 2012, na tentativa de obter a colaboração das empresas.

\subsection{APRESENTAÇÃO DOS RESULTADOS DO SURVEY}

Todas as respostas obtidas até a data de 30 de Março de 2012 foram categorizadas, quantificadas e analisadas. Obtiveram-se como resultado desta verificação, 21 questionários válidos. As informações neles contidos foram processadas nos sofware Excel, com base na codificação de todas as perguntas e respostas constantes dos questionários, tendo em vista a elaboração das figuras e tabelas de suporte à elaboração do Capitulo 4. $\mathrm{Na}$ análise dos dados foi realizada uma descrição resumida das respostas às diversas perguntas formuladas no questionário, que foi complementada pela apresentação das respectivas figuras e tabelas.

\subsection{LIMITAÇÕES DO ESTUDO}

$\mathrm{Na}$ realização do Survey foi complicado ter acesso aos contatos, houve reenvio dos questionários, demora de resposta e pouca disposição dos empreendedores ou 
responsáveis, profissionais LEED AP, empresas de consultoria, consultores em responderem os questionários, apesar da insistência. Estes complicadores, apesar de todos os esforços, limitaram a composição de uma amostra estatisticamente valida dentro do intervalo de confiança e margem determinados (5\%), mas não inviabilizaram a realização da pesquisa e um mapeamento abrangente da situação da certificação ambiental de edifícios no Brasil. 
Neste capitulo são apresentados e discutidos os resultados das aplicações dos questionários. Estes questionários são descritos por blocos temáticos, tal como apresentado na metodologia. A primeira parte deste capítulo apresenta os resultados dos empreendedores LEED e do Processo AQUA; a parte consecutiva apresenta os resultados dos profissionais credenciados LEED e dos consultores do Processo AQUA. Os resultados dos questionários enviados aos gerentes de facilidades de um prédio certificado com o LEED e outro com o Processo AQUA estão em Anexo B. As tabelas de frequência dos resultados obtidos pelos grupos segundo o respondente estão em Anexo C.

\subsection{EMPREENDEDORES}

\subsubsection{EMPREENDEDOR LEED}

\section{Dados do respondente}

Dos questionários enviados, quatro foram respondidos pelo empreendedor LEED; os outros, em sua maioria, foram respondidos pelos responsáveis do projeto designados pelo empreendedor devido a sua experiência, envolvimento e conhecimento com o tema. Para três respondentes é a primeira vez que participam do processo de certificação LEED.

\section{Dados do empreendimento}

O uso final dos edifícios foi de escritório (3), garagem (1), eco-mercado (1), laboratório e comercial/corporativo (1). Em geral, a maioria dos empreendimentos registrados junto ao USGBC são escritórios. Segundo Honda et al. (2010) os edifícios de escritórios têm sido alvo de pressão da comunidade e de empresas que incorporam a sustentabilidade na estratégia de seus negócios, que buscam instalar suas operações neste tipo de empreendimentos. Em relação ao nível de certificação, verifica-se que três das empresas têm procurado o nível de certificação ouro, três o nível prata e uma o nível certificado. Em geral, estes dois níveis de certificação do LEED (ouro e prata) são os mais procurados pelos empreendedores, isso indica que as empresas impulsionam a seus projetos para ir além do nível certificado que é o mínimo necessário para obter a certificação LEED. 


\section{Motivações para a certificação}

No que se refere às motivações, foram analisadas as motivações cuja importância se revelou mais importante para o empreendedor (pergunta 5). Na resposta a esta questão, os empreendedores selecionaram um fator sem ponderação. Os resultados obtidos indicam que as motivações mais importantes para obter a certificação foram "A empresa emprega a sustentabilidade na estratégia de seus negócios" (2), "Melhorar o resultado final" (1), "Exigências dos clientes e outras partes interessadas" (1).

Relativamente às motivações para a certificação LEED (pergunta 6), os empreendedores selecionaram os fatores relevantes que pontuaram numa escala de 1 a 5 , por ordem crescente de importância (1: Sem importância; 2: Pouco importante; 3: Regularmente importante; 4: Importante; 5: Muito importante). A frequência de respostas obtidas para os diversos fatores encontra-se representada na figura 5 .

Figura 5: Frequência de resposta das motivações dos empreendedores para a certificação

\section{LEED}

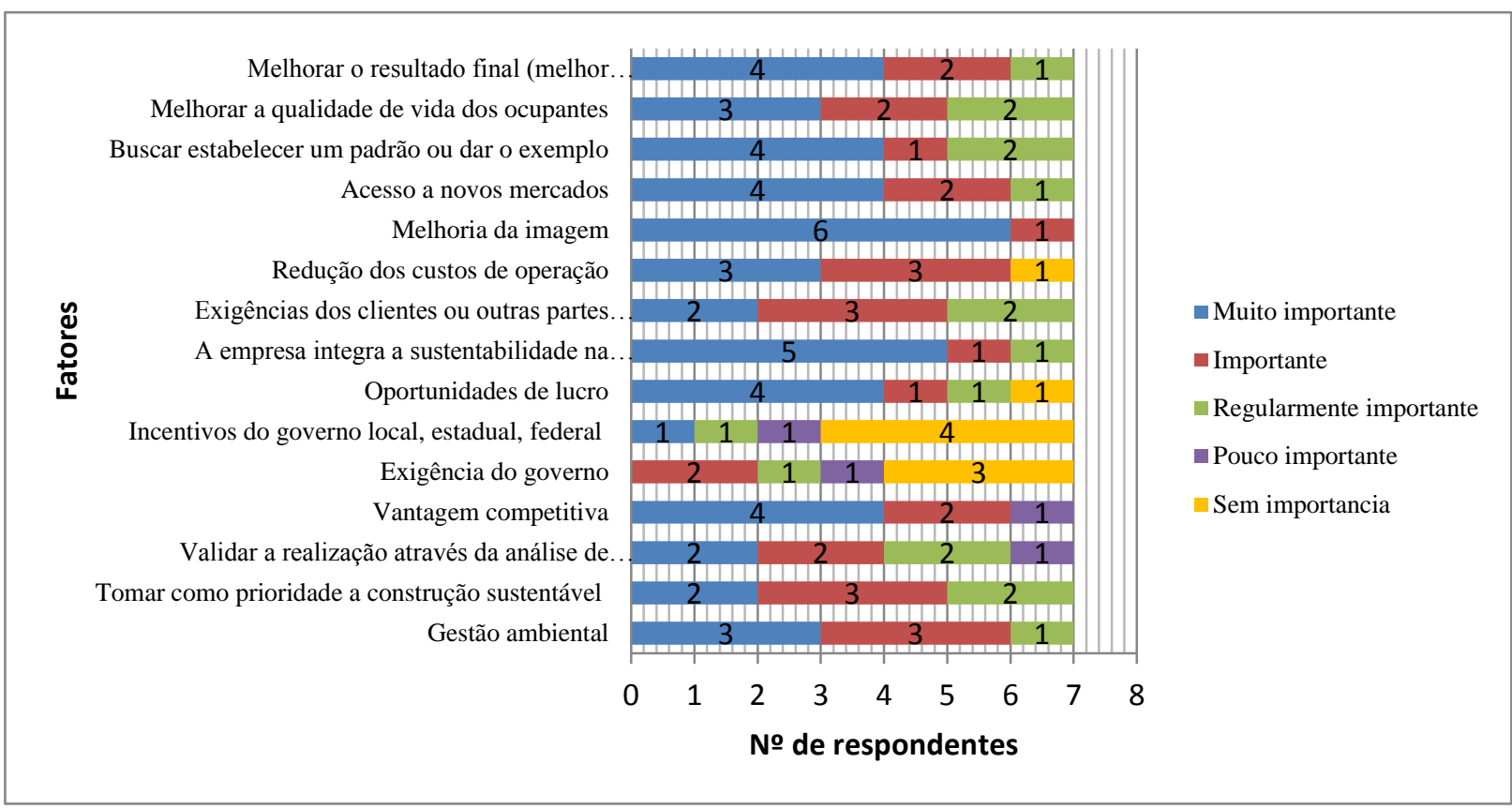

Com base nestes resultados, e admitindo que são relevantes todos os fatores pontuados pelas empresas como 5: Muito importante e 4: Importante, procedeu-se então à determinação das motivações para a certificação LEED.

Foram construídas figuras que apresentam a pontuação somada de respostas muito importante (5) e importante (4), representadas nas barras azuis. E nas barras vermelhas as percentagens dessa pontuação em relação ao máximo de pontuação possível. Destaca-se 
que se todos os respondentes atribuíssem a pontuação máxima para o item (muito importante -5 pontos) obteria-se 35 pontos. Por exemplo, na figura 6 a alternativa Melhorar o resultado final (melhor produtoledifício) foi apontado como muito importante por quatro respondentes e como importante por 2 respondentes, obtendo $4 \times 5$ pontos $+2 \times 4$ pontos $=28$ pontos, conforme representado na primeira barra azul da figura. Considerandose que $28 / 35=0,8$ o que significa $80 \%$ da pontuação máxima possível, como representa a primeira barra vermelha do gráfico abaixo.

Figura 6: Motivações dos empreendedores para a certificação LEED

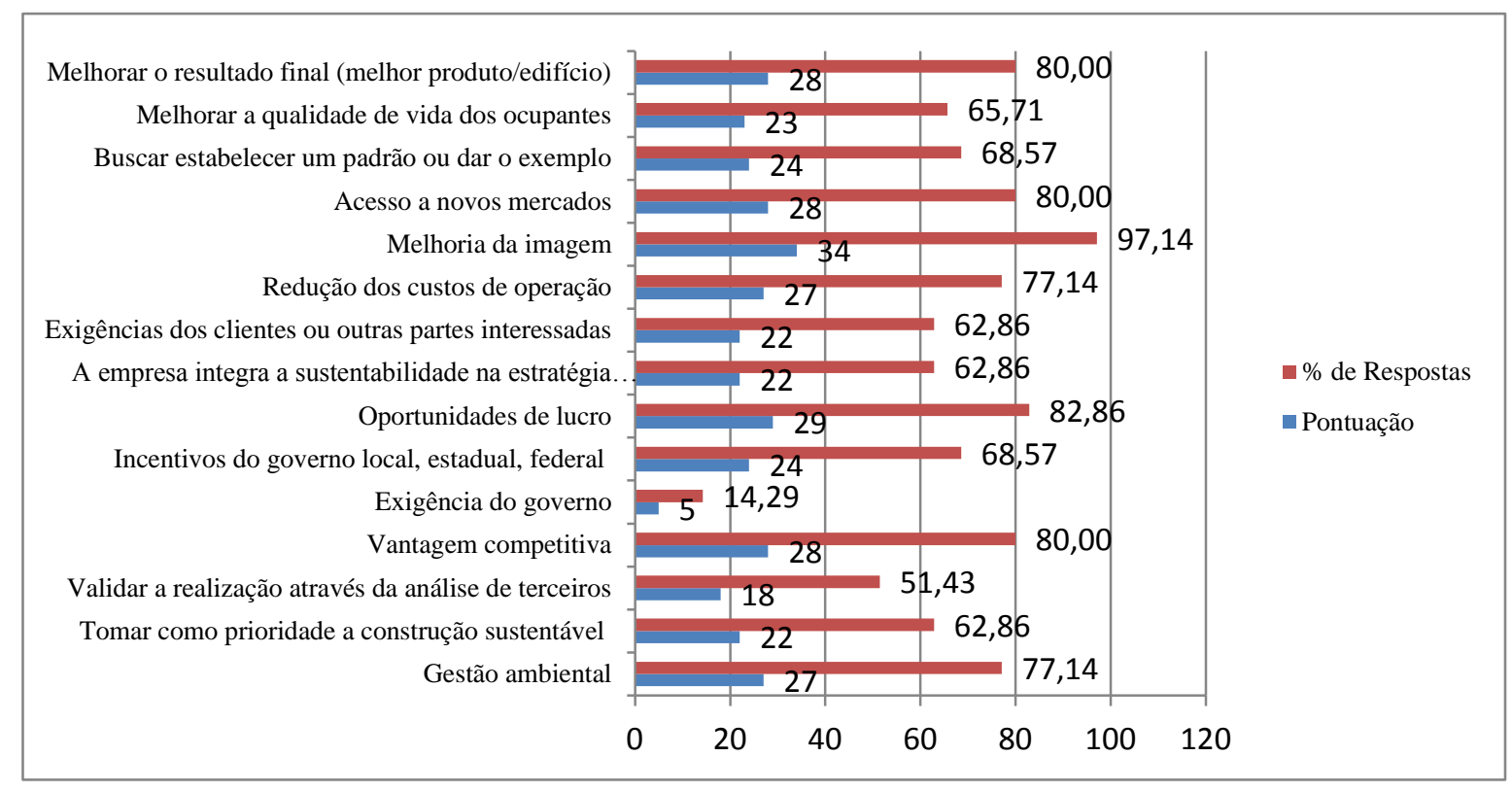

As principais motivações apontadas para a certificação LEED são a "Melhoria da imagem" (97,14\%), "Oportunidade de lucro" (82,86\%), "Melhorar o resultado final", "Acesso a novos mercados" e "Vantagem competitiva" todas com (80\%), "Gestão ambiental" e "Redução dos custos operacionais" ambas com (77,14\%).

Comparando estes resultados com as principais razões identificadas no estudo de Johnson (2005), verifica-se que estes aspectos são igualmente assinalados no presente trabalho ("Vantagens competitiva", "Oportunidade de lucro" e "Gestão ambiental"), no entanto, não existe uma aderência uma vez que não são referidos pela mesma ordem no presente trabalho.

Os resultados obtidos no que se refere à "Melhoria de imagem" confirmam os pressupostos enunciados por Lucuik et al., (2005) e Cryer et al., (2006), que mostram que as empresas que instalam suas operações em green building para demonstrar seu compromisso com a 
sustentabilidade e ser percepcionadas como tendo uma boa reputação ambiental ou imagem.

\section{Benefícios da implementação}

No que se refere aos benefícios, foram analisados os benefícios da obtenção da certificação cuja importância se revelou mais importante para o empreendedor (pergunta 7). Na resposta a esta questão, os empreendedores selecionaram um fator sem ponderação. Os resultados obtidos indicam que os benefícios mais importantes para obter a certificação foram "Imagem, diferenciação e valorização do empreendimento" (3) e "Tornam os empreendimentos mais atraentes o que garante um maior valor agregado" (1).

No que se referem aos benefícios da implementação da certificação LEED (pergunta 8), os entrevistados selecionaram os fatores relevantes que pontuaram numa escala de 1 a 5 , por ordem crescente de importância (1: Sem importância; 2: Pouco importante; 3: Regularmente importante; 4: Importante; 5: Muito importante). A frequência de respostas e a pontuação, construídas conforme explicado anteriormente (ver figura 6), encontram-se representadas na figura 7. 
Figura 7: Frequência de respostas dos empreendedores dos benefícios da implementação da certificação LEED

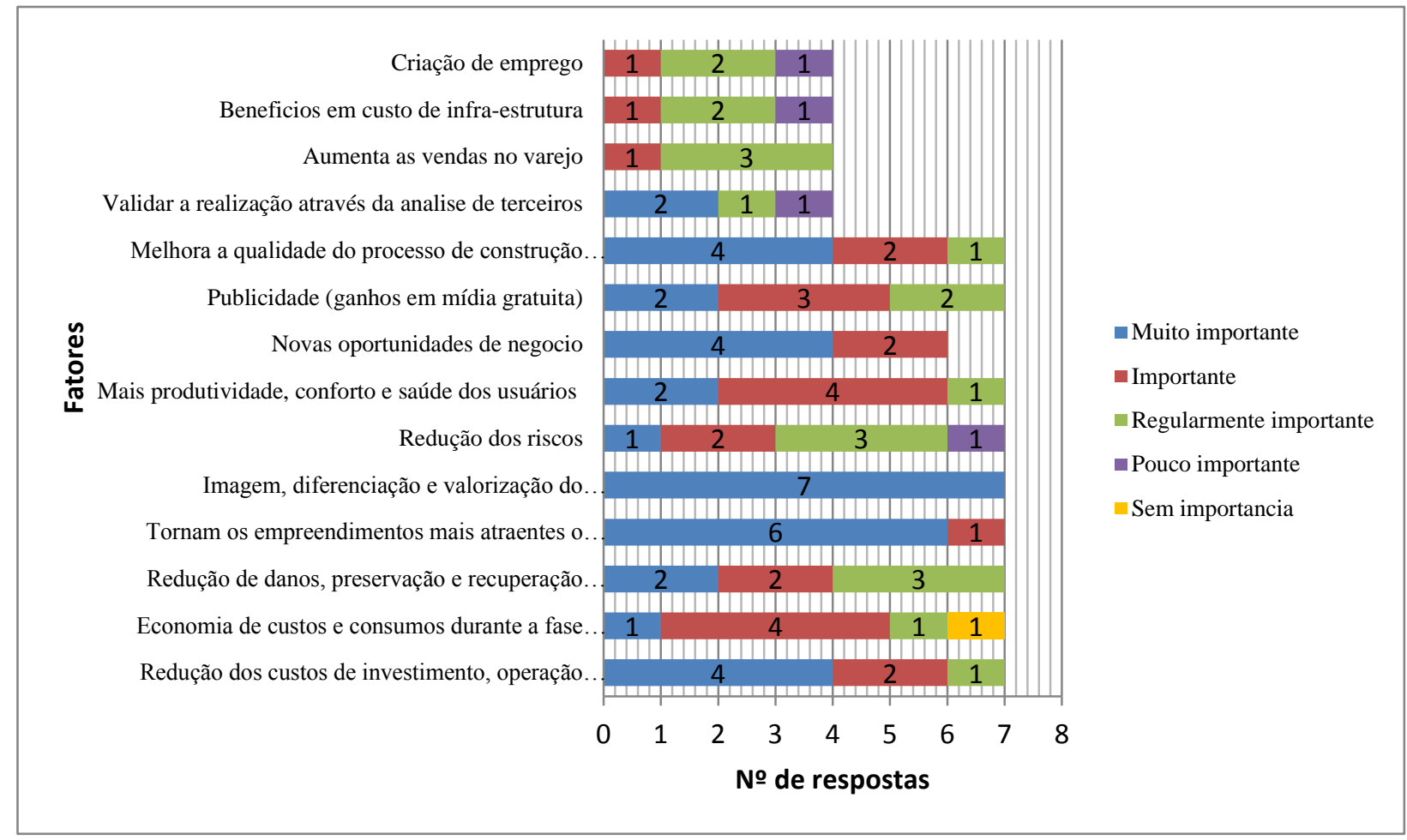

Com base nestes resultados, e admitindo que são relevantes todos os fatores pontuados pelas empresas como 5: Muito importante e 4: Importante, procedeu-se então à determinação dos benefícios da implementação da certificação LEED (figura 8).

Figura 8: Benefícios dos empreendedores da implementação da certificação LEED

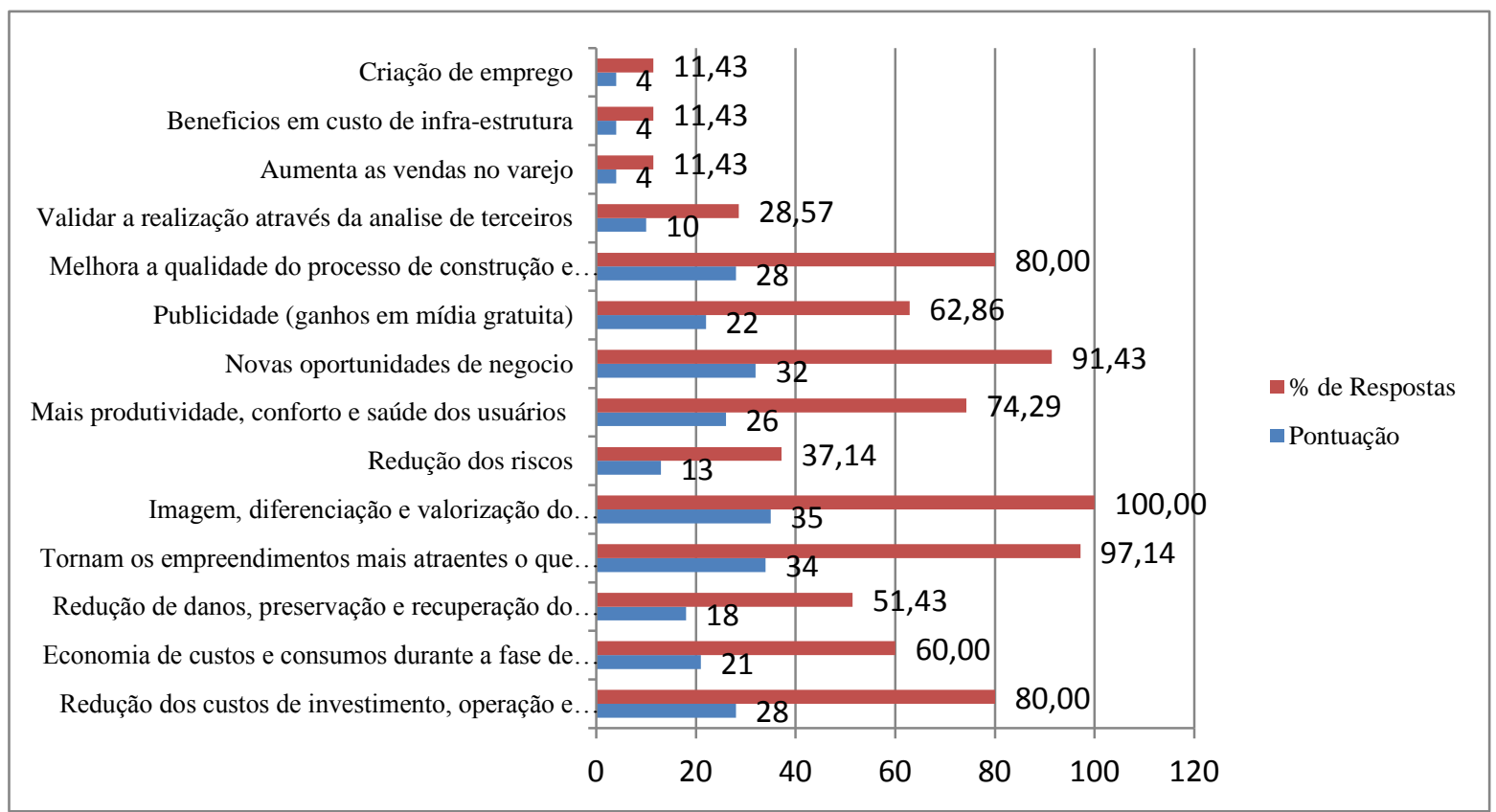


Os principais benefícios encontrados referem-se a "Imagem, diferenciação e valorização do produto" (100\%). Seguem-se, depois, por ordem decrescente da percentagem de respostas, "Tornam os empreendimentos mais atraentes o que garante maior" (97,14\%), "Novas oportunidades de negocio" (91,43\%), "Melhora a qualidade do processo de construção e do edifício" e "Redução dos custos de investimento, operação e manutenção" ambas com (80\%).

Os resultados encontrados que indicam que a certificação "torna os empreendimentos mais atraentes, o que garante maior valor" e a "imagem, diferenciação e valorização do produto" sustentam a opinião de que os edifícios sustentáveis têm benefícios de marketing significativos quando comparados com edificações convencionais. Estes dois benefícios indicam que o interesse das empresas volta-se principalmente para dar valor a mais a um empreendimento. Tal opinião esta de acordo com Lutzendorf et al. (2005) apud Pardini (2009) que indica que valor dado a um empreendimento depende da contribuição do edifício para a lucratividade do negocio e das razões subjetivas como imagem, identidade e outras preferências pessoais.

\section{Dificuldades da implementação}

No que se refere às dificuldades, foram analisadas as dificuldades da obtenção da certificação que se revelaram mais difícil para o empreendedor (pergunta 9). Na resposta a esta questão, os empreendedores selecionaram um fator sem ponderação. Os resultados obtidos indicam que as dificuldades mais difíceis para obter a certificação foram "Falta pessoal treinado-operarios (mão de obra qualificada)" (1), "Resistência dos projetistas e da construtora em implantar efetivamente algumas exigências (das categorias) solicitadas pela certificação LEED” (1), “Alto custo empregado para o projeto-execução do empreendimento verde" (1) e a "Dificuldade em qualificar para a certificação LEED desejada" (1).

No que se referem as dificuldades da implementação da certificação LEED (pergunta 10), os entrevistados selecionaram os fatores relevantes que pontuaram numa escala de 1 a 5 , por ordem crescente de importância (1: Sem dificuldade; 2: Pouco difícil; 3: Regularmente difícil; 4: Difícil; 5: Muito difícil). A frequência de respostas obtidas para os diversos fatores encontra-se representadas na figura 9. 
Figura 9: Frequência de respostas das dificuldades dos empreendedores para a implementação da certificação LEED

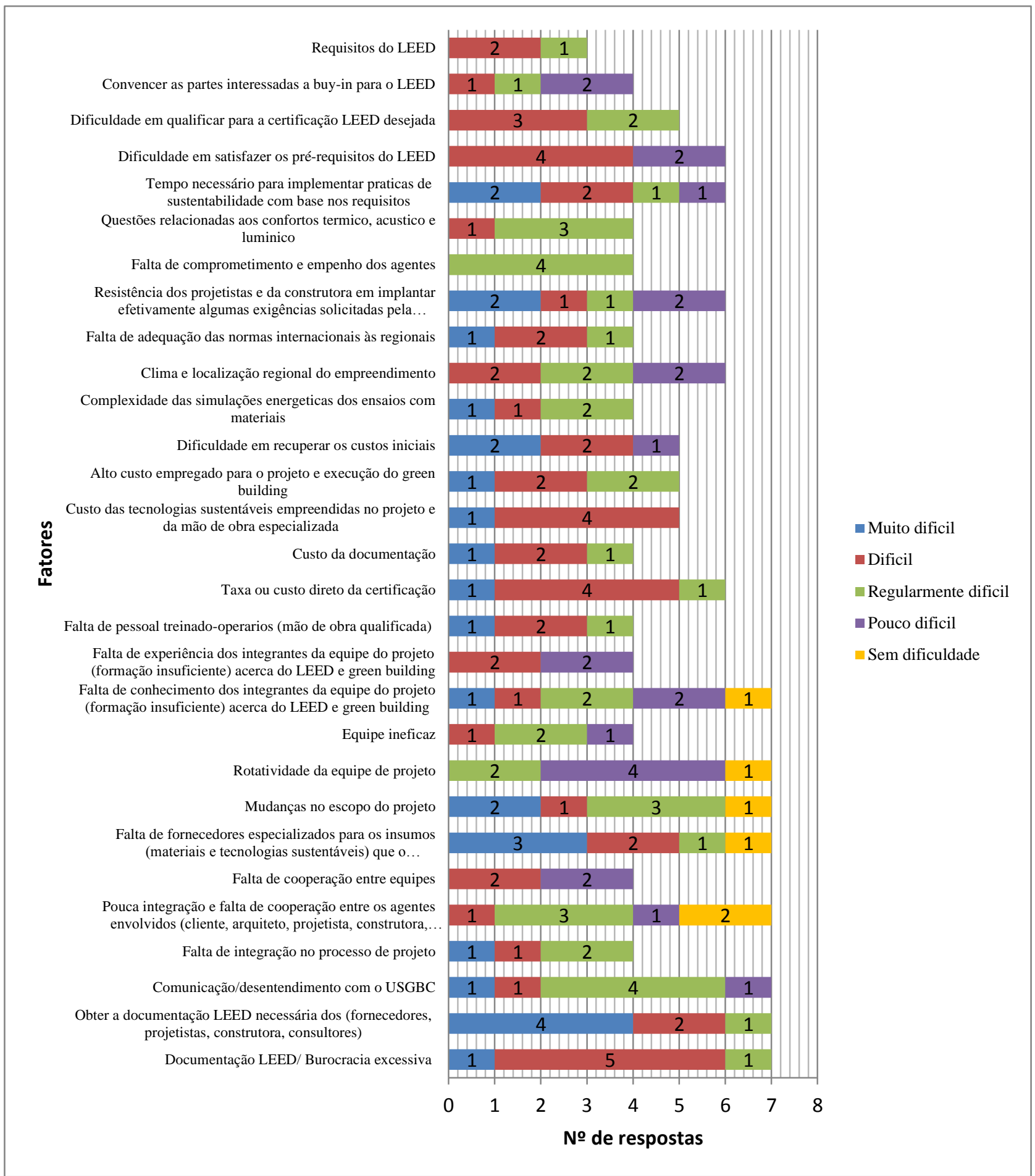

Com base nestes resultados, e admitindo que são relevantes todos os fatores pontuados pelas empresas como 5: Muito difícil e 4: Difícil, procedeu-se então à determinação das dificuldades da implementação da certificação LEED (figura 10). 
Figura 10: Dificuldades dos empreendedores para a implementação da certificação LEED

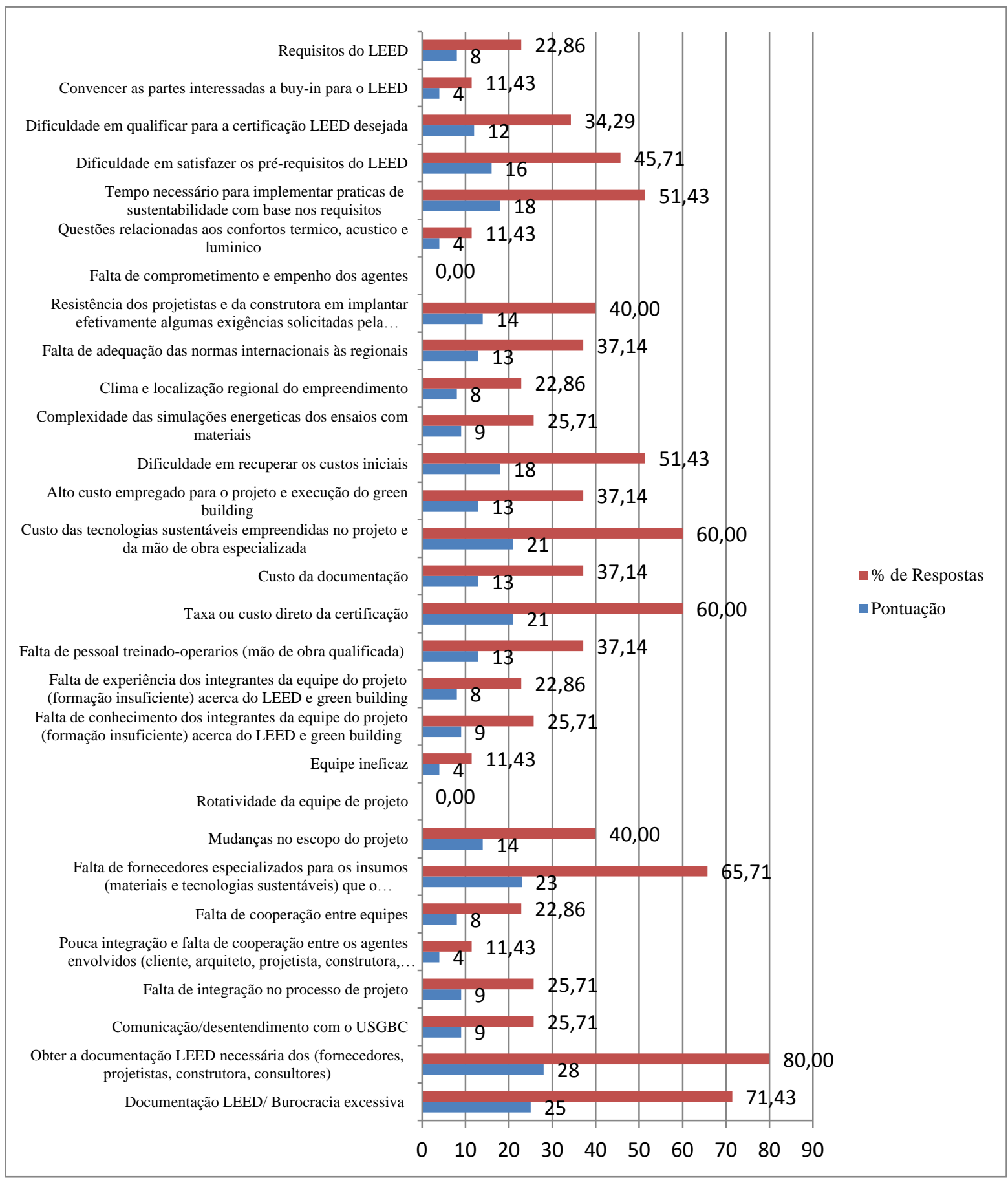

Em relação às principais dificuldades para a implementação do LEED, os empreendedores indicam, a "Obter a documentação LEED necessária dos fornecedores, projetistas, construtora e consultores" com (80\%). Seguem-se, com uma percentagem muito semelhante a "Documentação LEED/ Burocracia excessiva" (71,43\%). Por ordem decrescente da percentagem de respostas, seguem-se a "Falta de fornecedores especializados para os insumos" (65,71\%), "Custo das tecnologias sustentáveis empreendidas no projeto e da mão de obra especializada" e "Taxa ou custo direto da 
certificação" ambas com (60\%), "Tempo necessário para implementar praticas de sustentabilidade com base nos requisitos" e "Dificuldade em recuperar os custos iniciais" ambas com $(51,43 \%)$.

Comparando os resultados obtidos com as principais dificuldades da implementação do LEED ("Taxa ou custo direto da certificação" e "Dificuldade em recuperar os custos iniciais") no estudo de Johnson (2005), verifica-se que estes aspectos são igualmente assinalados no presente trabalho só que em ordem diferente, pois nesta situação, ocorre que os custos associados ao processo não são percepcionados como os problemas mais importante pelos respondentes. No presente trabalho, e ao contrario de Cryer et al. (2006), obter a documentação LEED não é o aspecto mais frequentemente referido. Já comparando os resultados obtidos com as dificuldades resultantes da obtenção da certificação no Brasil no estudo de Pardini (2009), verifica-se a coincidência em termos de "Dificuldade de encontrar fornecedores de materiais e soluções tecnológicas" e "Alto custo inicial".

A relevância atribuída a "Obter a documentação da equipe de trabalho" no presente trabalho confirmam a opiniões de Piccoli et al., (2010) que, consideram que a certificação LEED exige uma quantidade significativa de documentação e vários ensaios (analises, simulações e testes) de materiais. Relativamente a burocracia excessiva (que resulta na lentidão do processo e em montanhas de documentos) e ao alto custo (monetário, tempo e esforço) da certificação, enunciadas por Schendler e Udall (2005), também estas dificuldades são referidas no presente trabalho.

Ainda destacam-se outras dificuldades encontradas durante o processo de implementação do LEED (pergunta 11) pelos participantes da pesquisa:

$>$ O pioneirismo da certificação LEED no Brasil;

$>$ O projeto não se encaixa em nenhum dos níveis de classificação LEED;

$>$ Alto custo da certificação LEED;

$>$ Alto custo da mão de obra especializada;

$>$ A maneira de agir na obra;

$>$ Alto custo da obra;

$>$ Alto custo das tecnologias verdes (2);

$>$ Retorno do investimento inicial é a longo prazo;

$>$ Resistência das instaladoras em fiscalizar, documentar e executar a obra segundo as exigências do LEED;

$>$ Adequação às normas internacionais (2); 
$>$ Alguns itens da certificação LEED não agregam benefícios ao empreendimento;

$>$ Escassez de tecnologias e matérias verdes para atender os requisitos de certificação;

$>$ Falta de mão de obra qualificada;

$>$ Mudanças de rotinas de obra;

$>$ Nas rotinas de obra temos dificuldade em aprender o processo no inicio.

\section{Processo de certificação}

O Profissional credenciado LEED (6 respostas) foi responsável por orientar as decisões, fornecer informações sobre o processo de certificação, elaborar e organizar a documentação exigida pelo USGBC, para a maioria dos projetos.

Entre as dificuldades com os projetistas, empresa fiscalizadora, proprietário, empreendedor, fornecedores e construtora (pergunta 13) as mais mencionadas pelos respondentes foram:

$>$ Implantar o processo junto aos fornecedores;

$>$ Desenvolver fornecedores para atender a certificação LEED;

$>$ Escassa disponibilização de projetos detalhados,

$>$ Falta de compreensão do projeto pelo consultor e empresa fiscalizadora;

$>$ Dificuldade em acreditar no retorno financeiro;

$>$ Seguir todas as exigências da certificação LEED durante a execução e compra dos insumos;

$>$ Seguir os requisitos da certificação LEED;

$>$ Falta de conhecimento e experiência da equipe;

$>$ Falta de experiência dos consultores.

Sobre os custos adicionais (pergunta 14 e15) os respondentes estimaram custos adicionais distintos, como mostram as respostas do quadro 6. 
Quadro 6: Percepção do custo adicional pelos empreendedores da certificação LEED

\begin{tabular}{|c|c|c|}
\hline Empresa & $\begin{array}{l}\text { Percepção do custo adicional associado à } \\
\text { implementação da certificação LEED }\end{array}$ & $\begin{array}{l}\text { Percepção do custo adiciona } \\
\text { de construção em relação ao } \\
\text { edifício convencional }\end{array}$ \\
\hline E1(edif. Escritório- prata) & $\begin{array}{l}10 \% \text { certificação } \\
20 \% \text { consultoria }\end{array}$ & \\
\hline E2 (edif. Escritório-ouro) & $10 \%$ no total & de $5 \%$ a $20 \%$ do total \\
\hline \multicolumn{3}{|l|}{ E3 ( prata) } \\
\hline E4 (edif. Garagem-ouro) & $10 \%$ do valor geral da obra & $10 \%$ do valor geral da obra \\
\hline $\begin{array}{l}\text { E5 (edif.eco-mercado } \\
\text { Certificado) }\end{array}$ & $\begin{array}{l}\text { Certificação no valor total de: } \mathrm{R} \$ \\
86.000,00 \text { diluídos em: } \\
\text { Consultoria: } \mathrm{R} \$ 54.000,00 \\
\text { Projeto de finalização: } \mathrm{R} \$ 27.000,000 \\
\text { Acompanhamento mensal: } \mathrm{R} \$ 54.000,00 \\
\text { Fase pré-operação e pós-entrega: } \mathrm{R} \$ \\
3.000,00 \\
\text { Obtenção da licença de operação: } \mathrm{R} \$ \\
2.000,00 \\
\text { Projeto: } 10 \% \\
\text { Materiais, ensaios e operações: } 15 \% \text { a } \\
\text { mais. }\end{array}$ & $10 \%$ \\
\hline E6 (edif. Escritorio-Ouro ) & em torno de $18 \%$ & $20 \%$ \\
\hline $\begin{array}{l}\text { E7(edif. Comercial/ } \\
\text { corporativo- prata ) }\end{array}$ & $4 \%$ & \\
\hline
\end{tabular}

Os respondentes, quando confrontados com a medida em que a certificação LEED afeta o processo de projeto, execução e produto final, selecionaram os fatores relevantes que pontuaram numa escala de 1 a 5, por ordem crescente (1: Muito pior, 2: Pior, 3: Similar, 4: Melhor; 5: Muito melhor). A frequência de respostas obtidas para os fatores encontra-se na figura 11 .

Figura 11: Frequência de respostas dos empreendedores relacionadas ás etapas do empreendimento afetadas pela certificação LEED

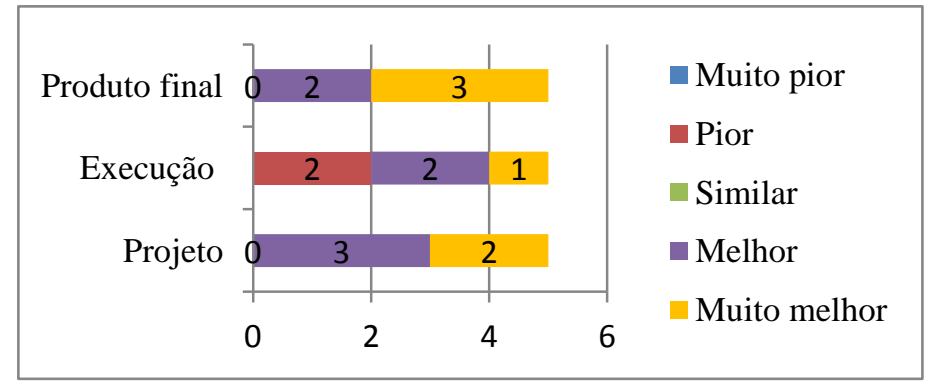

Com base nestes resultados, e admitindo que são relevantes todos os fatores pontuados pelas empresas como 5: Muito melhor e 4: Melhor, procedeu-se então à determinação das etapas do empreendimento afetadas pela certificação. 
Figura 12: Etapas do empreendimento afetadas positivamente pela certificação LEED segundo os empreendedores

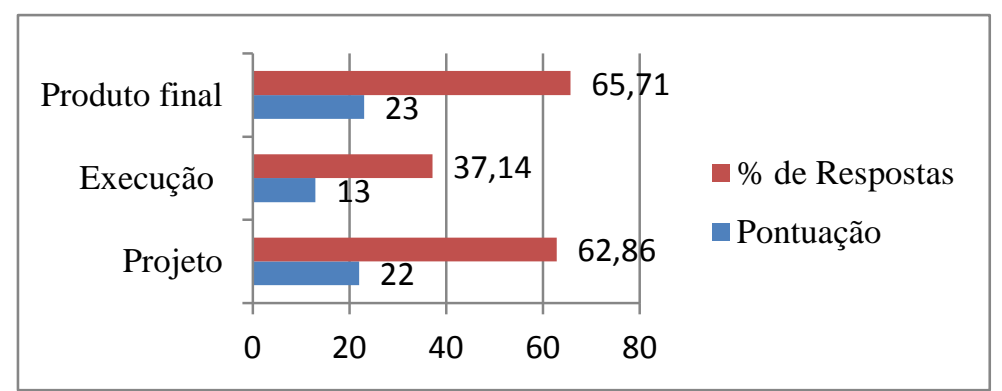

Com base na figura 12 percebe-se que os respondentes consideram que o produto final é o principal beneficiado da certificação, seguido do projeto. Já com relação a execução são apontados óbices. Com esse resultado é possível perceber que as ações do processo de certificação LEED podem afetar negativamente a construção do empreendimento porque podem gerar impactos e atrasos no processo de entrega da obra.

No que se refere ainda às categorias, foram analisadas as categorias exigidas pelo LEED, cujo atendimento se revelou mais complicadas para as empresas. Na resposta a esta questão, os respondentes selecionaram os fatores relevantes que pontuaram numa escala de 1 a 5, por ordem decrescente de dificuldade (1: Muito fácil; 2: Fácil; 3: Indiferente; 4: Difícil; 5: Muito difícil).A frequência de respostas obtidas para os diversos fatores encontra-se representada na figura 13.

Figura 13: Frequência de respostas dos empreendedores das dificuldades em atingir as categorias exigidas pelo LEED

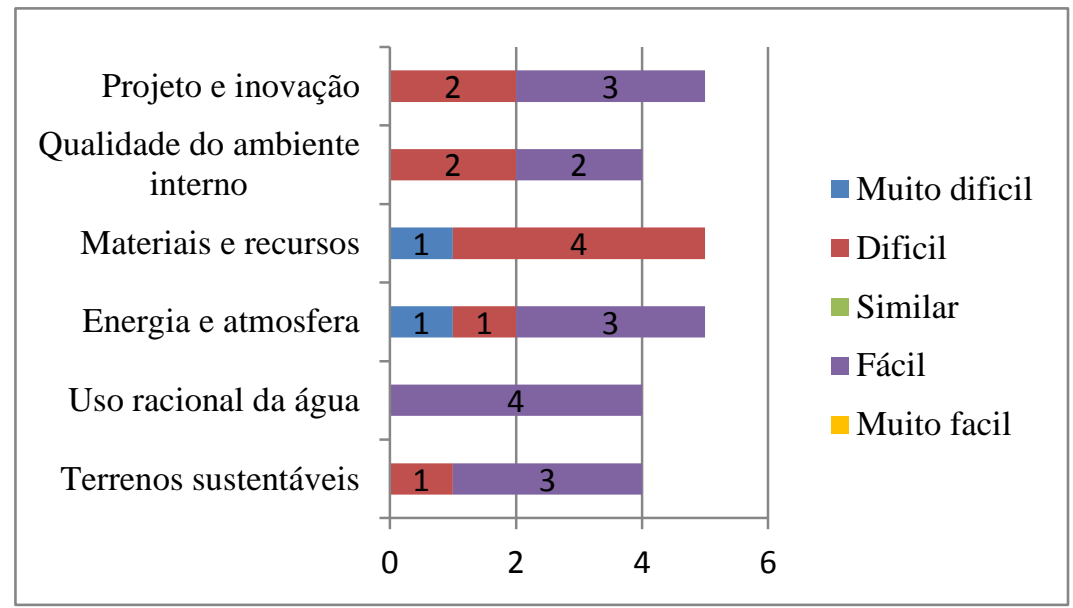


Com base nestes resultados, e admitindo que são relevantes todos os fatores pontuados pelas empresas como 5: Muito difícil e 4: Difícil, procedeu-se, então à determinação das dificuldades com as categorias exigidas pelo LEED (figura 14).

Figura 14:Dificuldades dos empreendedores em atingir as categorias exigidas pelo LEED

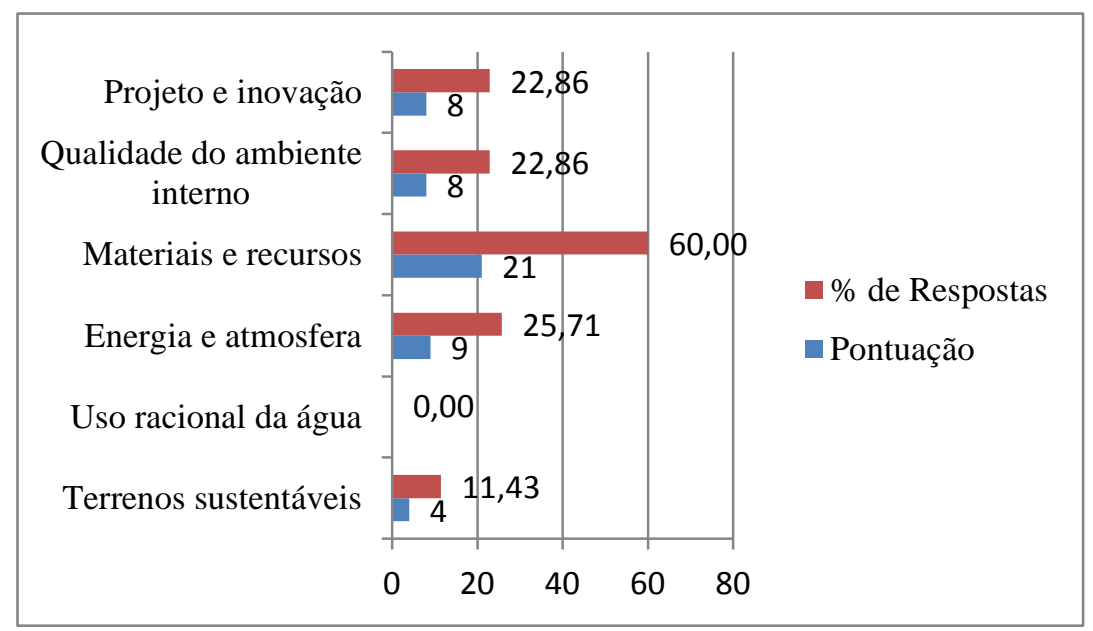

A categoria exigida pelo LEED mais difícil de se atender refere-se a "Materiais e recursos" (60\%). Seguem-se, depois, por ordem decrescente da percentagem de respostas, "Energia e atmosfera" (25,71\%), “Projeto e inovação", "Qualidade do ambiente interno" (22,86\%) e "Terrenos sustentáveis" (11,43\%).

\section{Evolução da certificação}

Os respondentes, quando confrontados com a forma como poderá ser melhorado o processo de certificação LEED, selecionaram um número limitado de fatores na resposta a esta questão. Os resultados obtidos indicam que as oportunidades de melhoria mais frequentemente assinalada pelos respondentes são "Simplificando a documentação e "Menos burocracia / interface on-line"

\subsubsection{EMPREENDEDOR DO PROCESSO AQUA}

\section{Dados do respondente e do empreendimento}

Dos questionários enviados todos foram respondidos pelo empreendedor. O uso final dos edifícios é de escolas e condomínio (2 e 1 respectivamente). O empreendedor/investidor (2 respostas) é o principal responsável de iniciar o Processo AQUA. 


\section{Motivações para a certificação}

No que se refere às motivações, foram analisadas as motivações cuja importância se revelou mais importante para o empreendedor (pergunta 3). Na resposta a esta questão, os empreendedores selecionaram um fator sem ponderação. Os resultados obtidos indicam que as motivações mais importantes para obter a certificação foram "A empresa emprega a sustentabilidade na estratégia de seus negócios" (2) e "Tornar como prioridade a construção sustentável" (1).

Relativamente às motivações para o Processo AQUA (pergunta 4), os empreendedores selecionaram os fatores relevantes que pontuaram numa escala de 1 a 5 , por ordem decrescente de importância (1: Sem importância; 2: Pouco importante; 3: Regularmente importante; 4: Importante; 5: Muito importante). A frequência de resposta obtida para os diversos fatores encontra-se representada na figura 15 .

Figura 15: Frequência de resposta das motivações dos empreendedores para o Processo AQUA

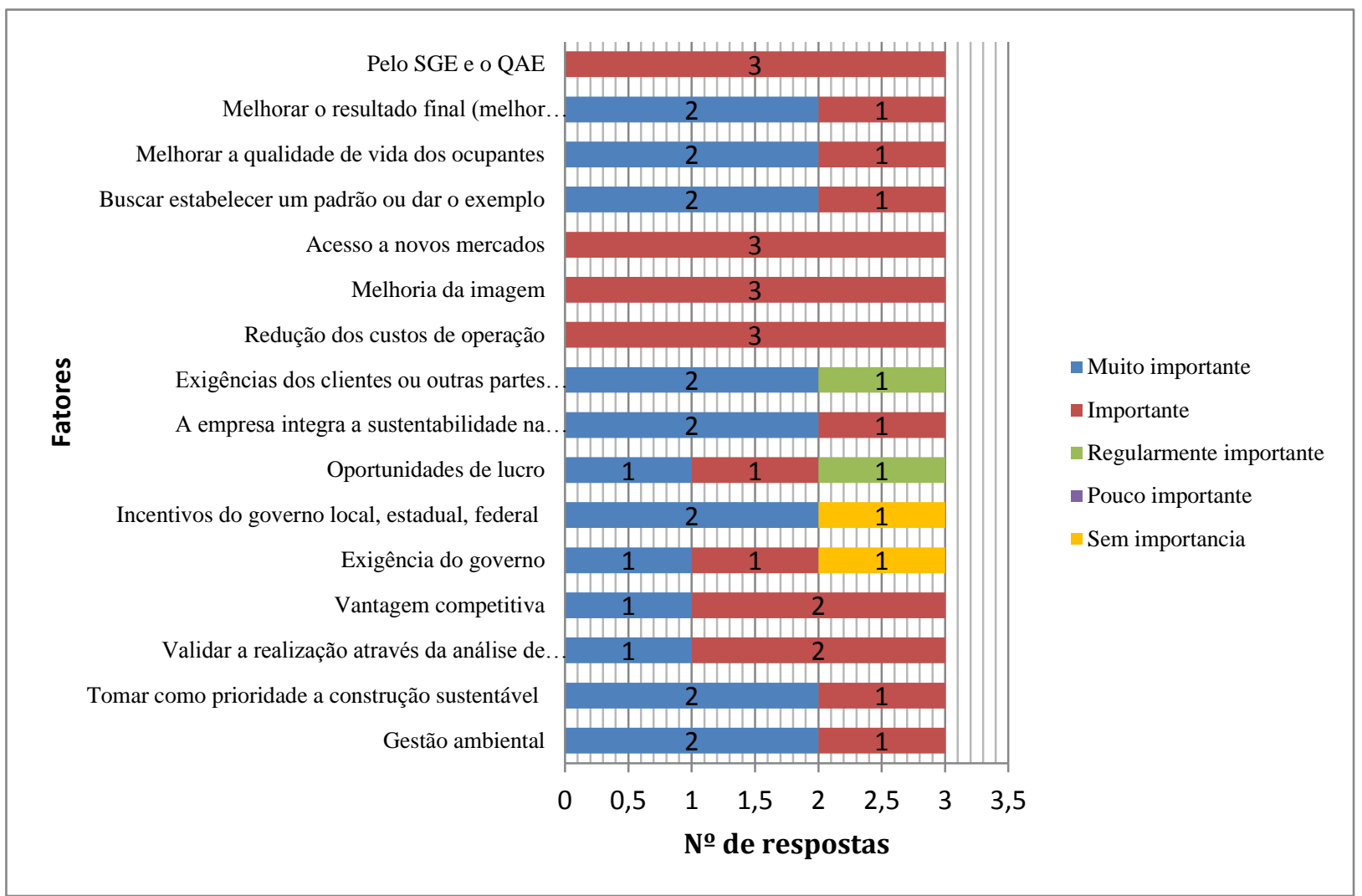

Com base nestes resultados, e admitindo que sejam relevantes todos os fatores pontuados pelas empresas como 5: Muito importante e 4: Importante, procedeu-se então à determinação das motivações para o Processo AQUA (figura 16). 
Foram construídas figuras que apresentam a pontuação somada de respostas muito importante (5) e importante (4), representadas nas barras azuis. E nas barras vermelhas as percentagens dessa pontuação em relação ao máximo de pontuação possível. Destaca-se que se todos os respondentes atribuíssem a pontuação máxima para o item (muito importante -5 pontos) obteria-se 15 pontos. Por exemplo, na figura 16 a alternativa Melhorar o resultado final (melhor produto/edifício) foi apontado como muito importante por dois respondentes e como importante por 1 respondente, obtendo $2 \times 5$ pontos $+1 \mathrm{x} 4$ pontos $=14$ pontos, conforme representado na primeira barra azul da figura. Considerandose que $14 / 15=0,93$ o que significa $93,33 \%$ da pontuação máxima possível, como representa a primeira barra vermelha do gráfico abaixo.

Figura 16: Motivações dos empreendedores para o Processo AQUA

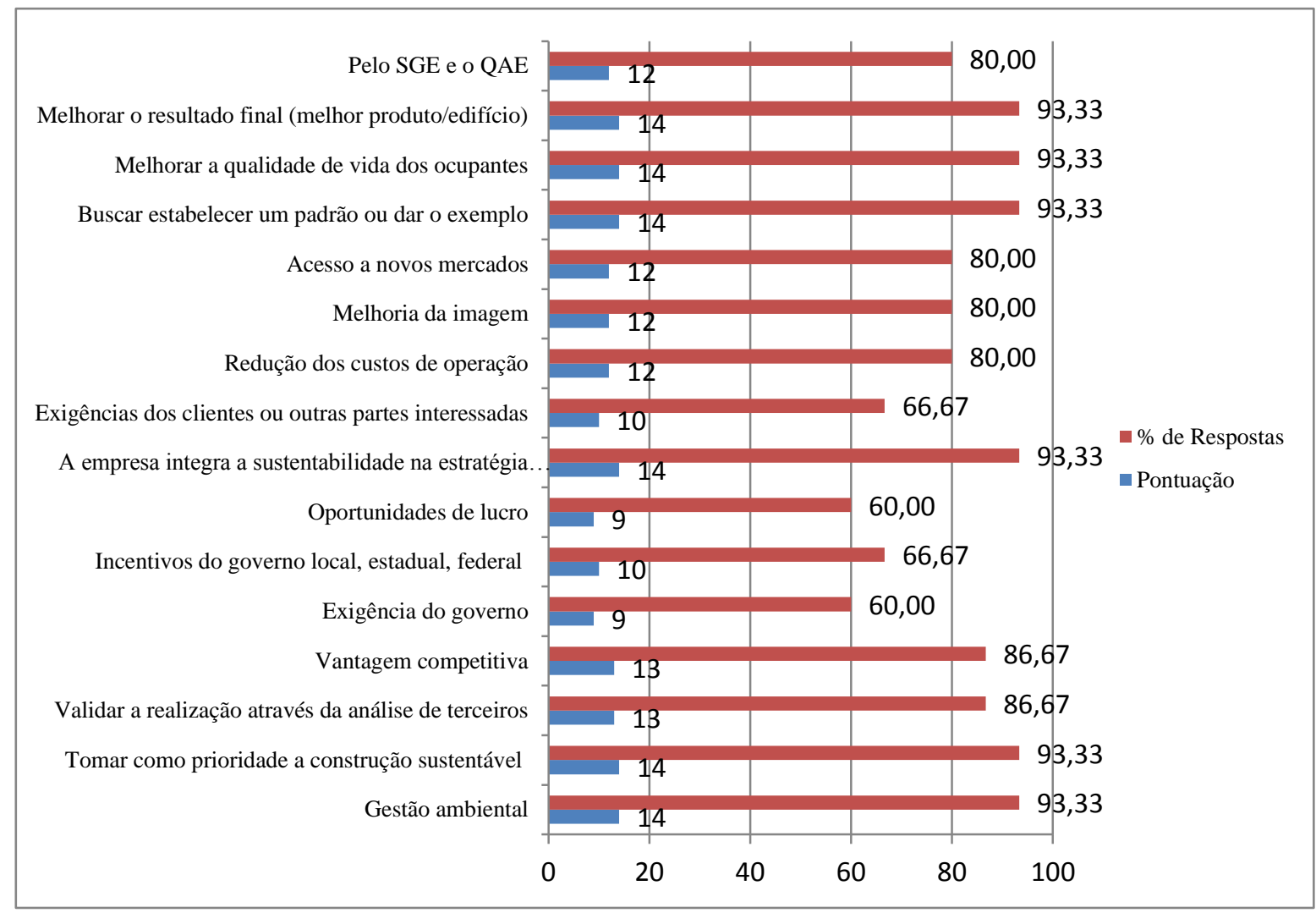

As principais motivações para o Processo AQUA são "Melhorar o resultado final", "Melhoria da qualidade de vida dos ocupantes", "Buscar estabelecer um padrão ou dar o exemplo", "A empresa integra a sustentabilidade na estratégia de seus negócios", "Tomar como prioridade a construção sustentável" e "Gestão ambiental” todas com 93,33\% das respostas, seguindo-se "Validar a realização através da analise de terceiros" e "Vantagem competitiva" ambas com $86,66 \%$. 


\section{Benefícios da implementação}

No que se refere aos benefícios, foram analisados os benefícios da obtenção da certificação cuja importância se revelou mais importante para o empreendedor (pergunta 5). Na resposta a esta questão, os empreendedores selecionaram um fator sem ponderação. Os resultados obtidos indicam que os benefícios mais importantes para obter a certificação foram "Redução de danos, preservação e recuperação do meio ambiente" (2) e "Mais produtividade, conforto e saúde do usuário" (1).

No que se referem aos benefícios da implementação do Processo AQUA (pergunta 6), os empreendedores selecionaram os fatores relevantes que pontuaram numa escala de 1 a 5 , por ordem decrescente de importância (1: Sem importância; 2: Pouco importante; 3: Regularmente importante; 4: Importante; 5: Muito importante). A frequência de respostas obtidas para os diversos fatores encontra-se representadas na figura 17.

Figura 17: Frequência de resposta dos benefícios da implementação do Processo AQUA segundo os empreendedores

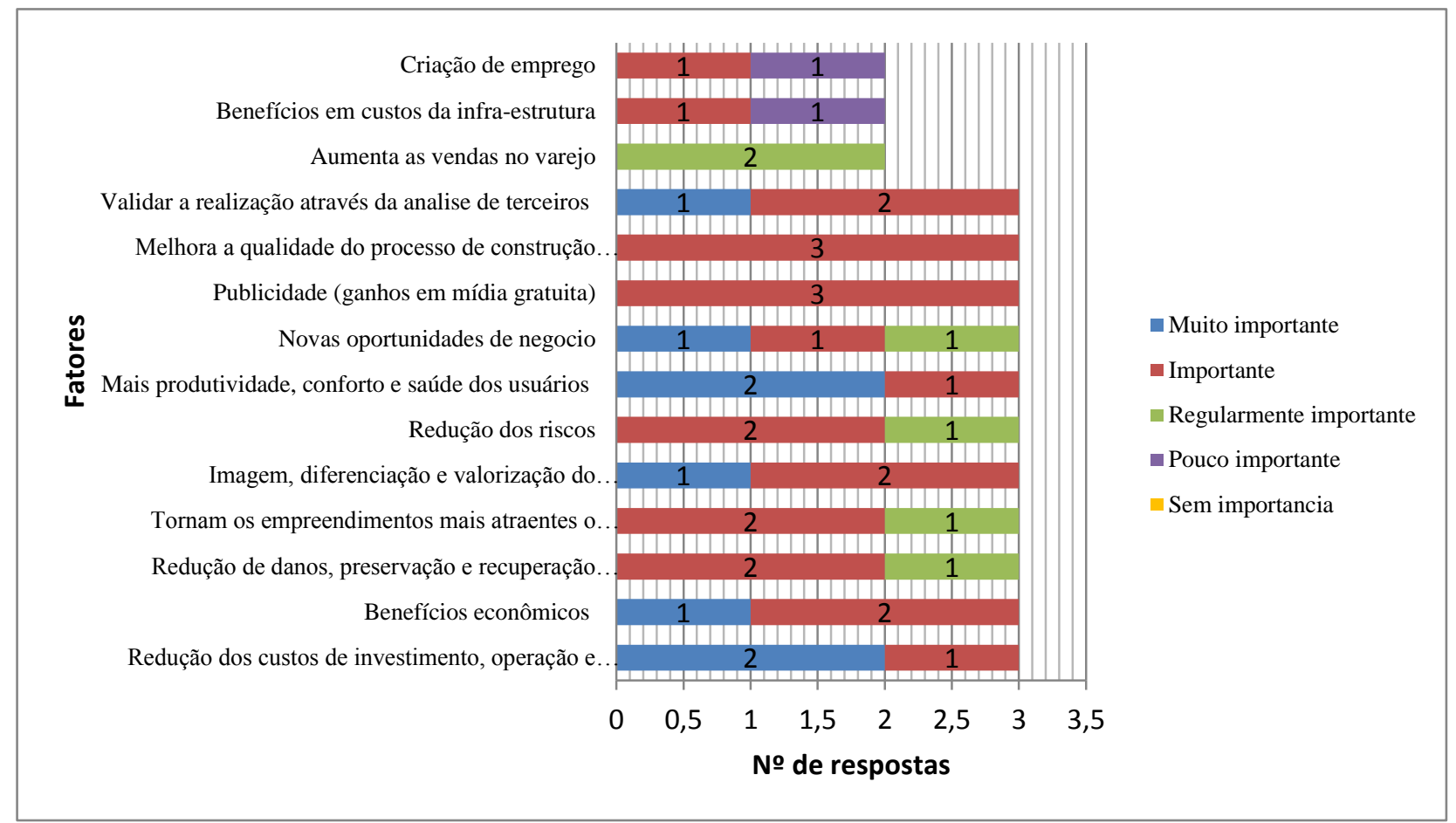

Com base nestes resultados, e admitindo que são relevantes todos os fatores pontuados pelas empresas como 5: Muito importante e 4: Importante, procedeu-se então à determinação dos benefícios da implementação do Processo AQUA (figura 18). 
Figura 18: Benefícios da implementação do Processo AQUA segundo os empreendedores

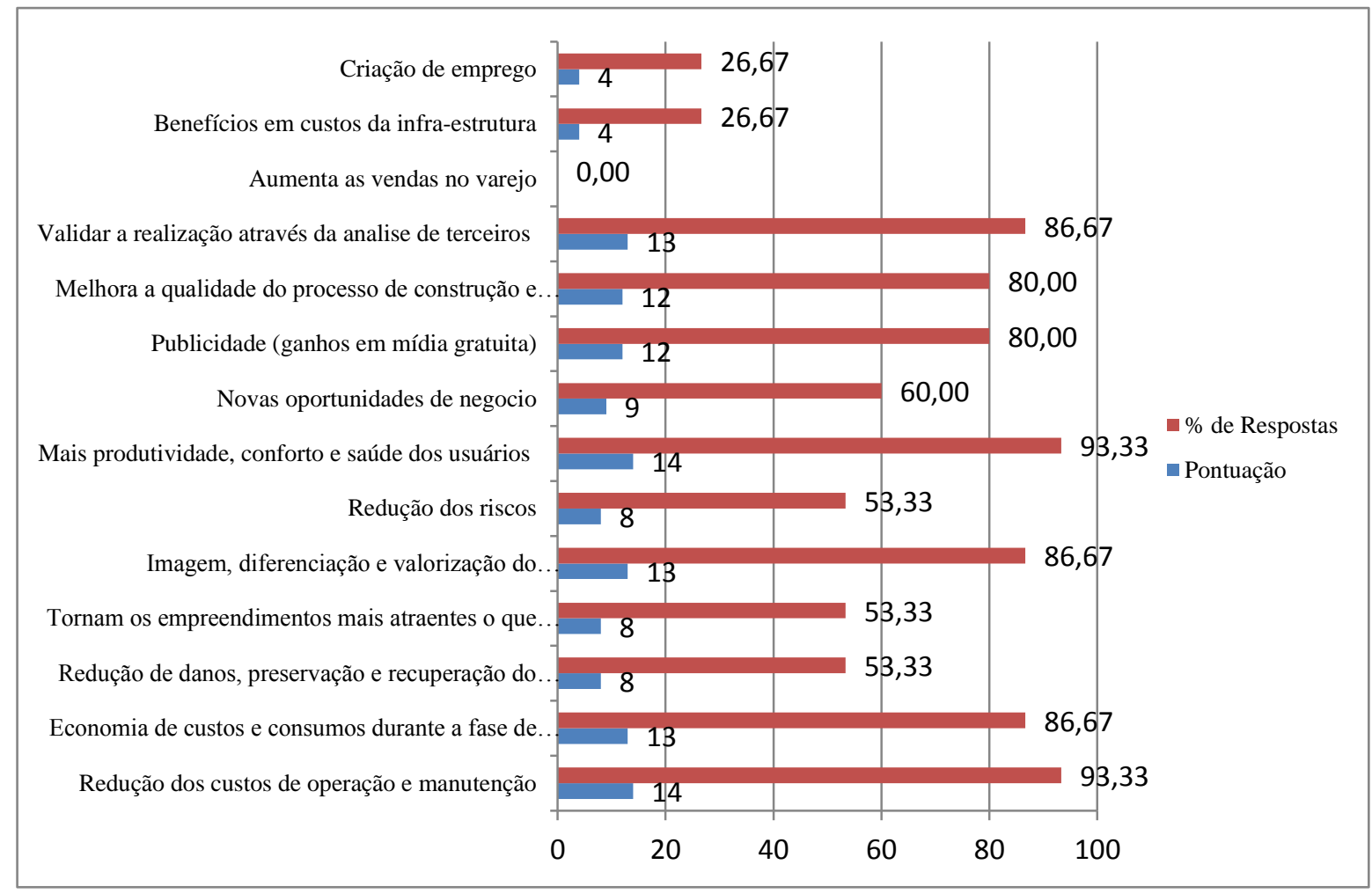

Os principais benefícios encontrados referem-se a "Mais produtividade, conforto e saúde dos usuários" e à "Redução dos custos operacionais e de manutenção", ambas com (93,33\%). Seguem-se, depois, por ordem decrescente da percentagem de respostas, "Validar a realização através da analise de terceiros", a "Imagem, diferenciação e valorização do empreendimento", a "Economia de custos e consumos durante a fase de construção" todas com $(86,67 \%)$, a "Melhora a qualidade do processo de construção e do edifício" e a "Publicidade (ganhos em mídia gratuita)" ambas com (80\%).

\section{Dificuldades da implementação}

No que se refere às dificuldades, foi analisada a dificuldade para obter a certificação que se revelou mais difícil para o empreendedor (pergunta 7). Na resposta a esta questão, os empreendedores selecionaram um fator sem ponderação. Os resultados obtidos indicam que as dificuldades mais difíceis para obter a certificação foram "Convencer as partes interessadas a buy-in (pagar) para o Processo AQUA" (1) e a "Falta de fornecedores especializados para os insumos (materiais e tecnologias sustentáveis) que o empreendimento demanda ou demandou" (2).

Em relação às dificuldades encontradas no processo de implementação do Processo AQUA (pergunta 8), os respondentes selecionaram os fatores relevantes que pontuaram numa escala de 1 a 5, por ordem decrescente de importância (1: Sem dificuldade; 2: Pouco 
difícil; 3: Regularmente difícil; 4: Difícil; 5: Muito difícil). A frequência de respostas obtidas para os diversos fatores encontra-se representadas na figura 19.

Figura 19: Frequência de resposta das dificuldades dos empreendedores para a implementação do Processo AQUA

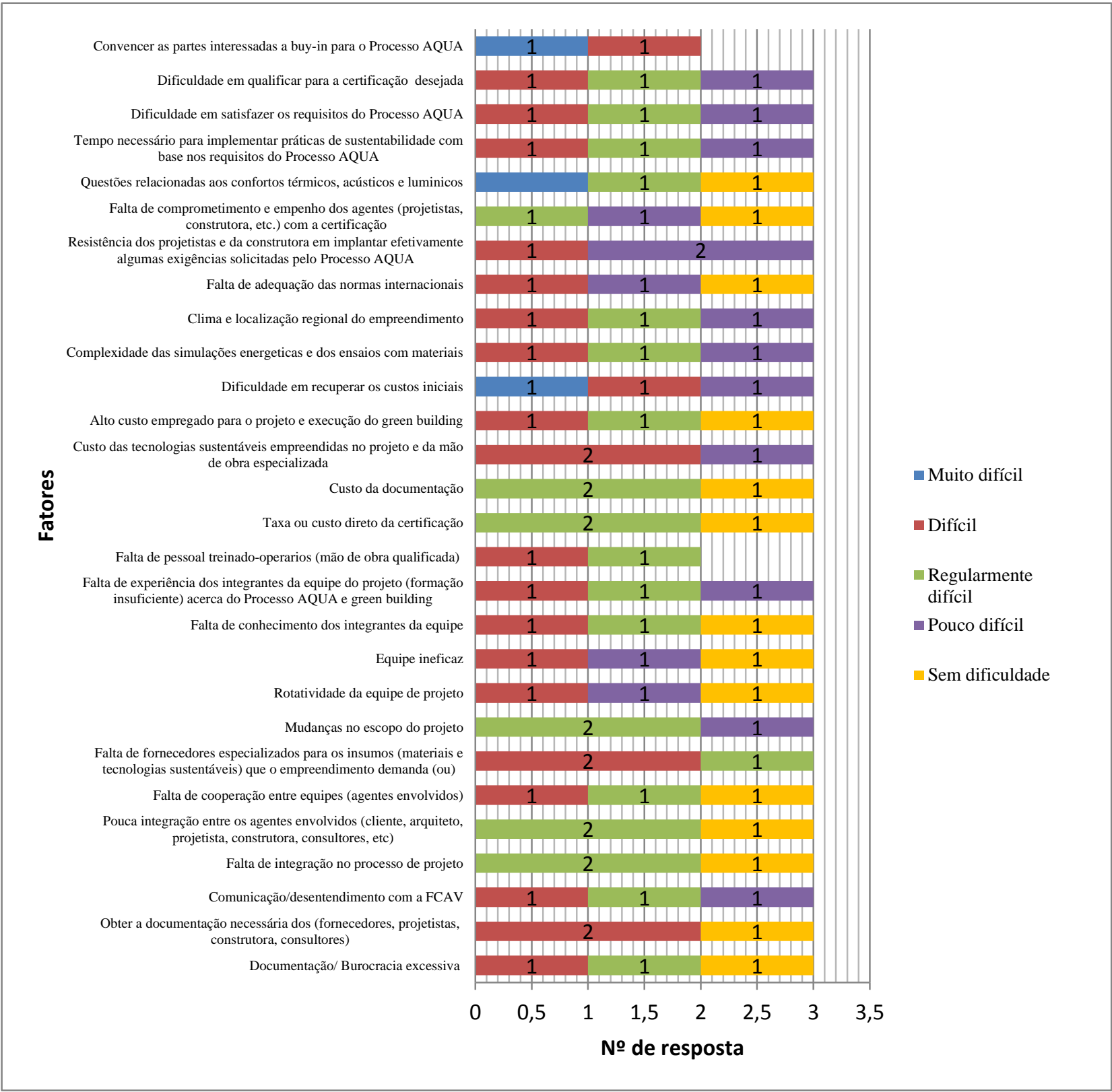

Com base nestes resultados, e admitindo que são relevantes todos os fatores pontuados pelas empresas como 5: Muito difícil e 4: Difícil, procedeu-se então à determinação das dificuldades da implementação do Processo AQUA (figura 20). 
Figura 20: Dificuldades da implementação do Processo AQUA segundo os empreendedores

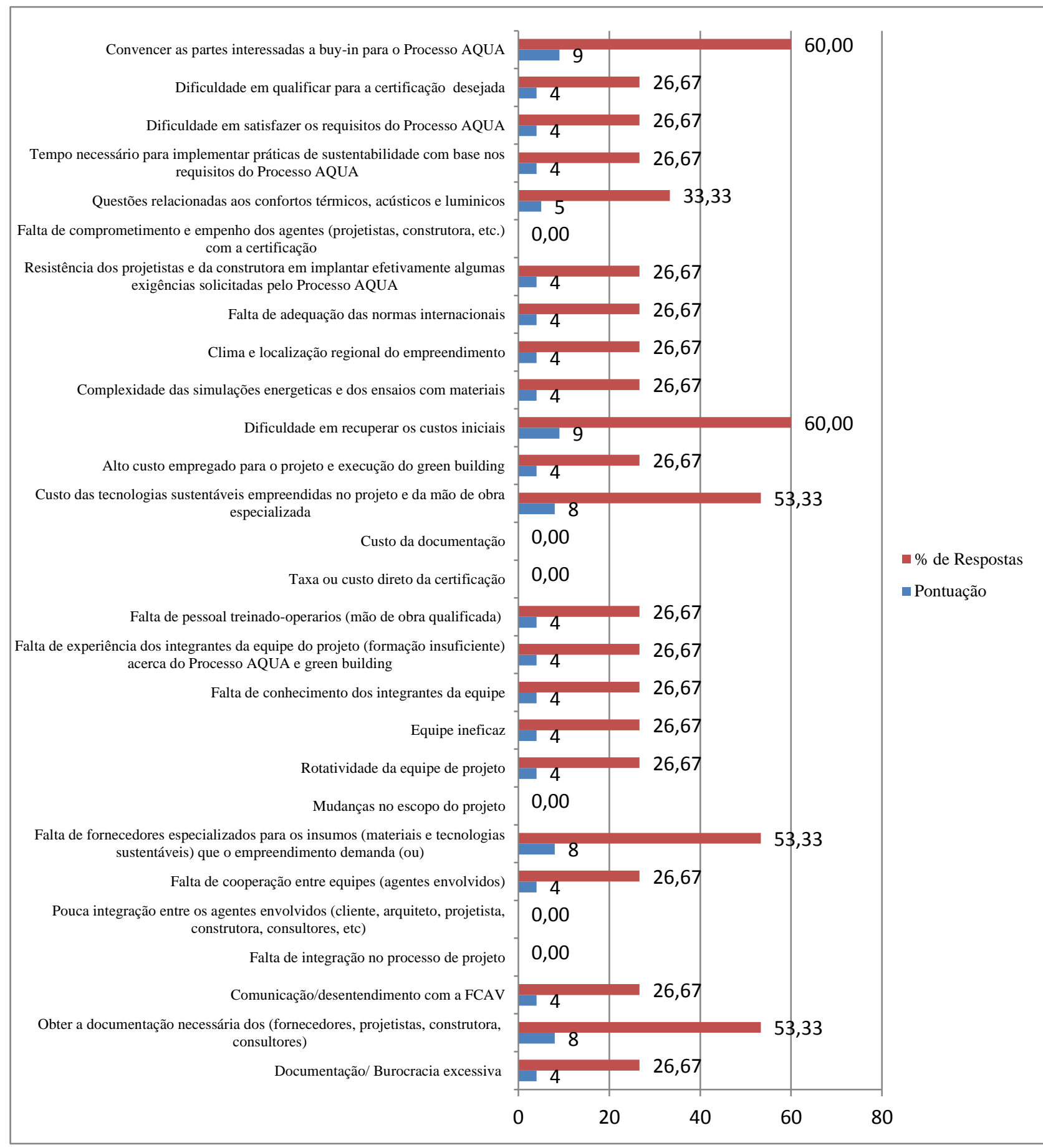

Em relação às principais dificuldades para a implementação do Processo AQUA, a principal dificuldade foi com a "Dificuldade em recuperar os custos iniciais" e "Convencer as partes interessadas a buy-in para o Processo AQUA" ambas com (60\%). Seguem-se, depois, por ordem decrescente da percentagem de respostas, "Obter a documentação necessária dos (fornecedores, projetistas, construtora, consultores)", "Falta de fornecedores 
especializados para os insumos (materiais e tecnologias sustentáveis) que o empreendimento demanda" e "Custo das tecnologias sustentáveis empreendidas no projeto e da mão de obra especializada"com a mesma percentagem de respostas $(53,33 \%)$ e "Questões relacionadas aos confortos térmicos, acústicos e luminicos" com (33,33\%).

\section{Processo de certificação}

Nas perguntas (11 e 12) sobre os custos constata-se que o 66,70\% dos respondentes não responderam a estas questões. Algumas das observações foram feitas, como segue:

$>$ Não houve dificuldade já que estávamos bem assessorados e o equipe tem entusiasmo com a certificação;

$>$ Entre o custo adicional em relação a uma edificação convencional um respondente mencionou que há $4 \%$ a mais do custo na obra;

$>$ Entre de sucesso para a gestão do processo de projeto foi mencionado na analise criteriosa de todas as tomadas de decisão.

O consultor do Processo AQUA e o empreendedor (2 e 1 respectivamente) são os responsáveis pelo fluxo de informações entre projetistas, especialistas e empreendedor e de estruturar os documentos exigidos pelo Processo de certificação AQUA. A incorporadora e a empresa de consultoria ( 3 e 2 respectivamente) têm profissionais com conhecimento sobre o processo de certificação AQUA. O grau de dificuldade em elaborar os documentos exigidos pelo Processo AQUA depende de cada empreendedor; quanto mais comprometido este, menos dificuldade vai ter em obter a documentação.

As principais dificuldades encontradas com os projetistas, empresa fiscalizadora, consultor, fornecedores (pergunta 15) foram:

$>$ Falta de integração da equipe de projeto;

$>$ Apresentação de memoriais de cálculo adequados aos requisitos da norma.

Entre as barreiras internas e externas (pergunta 19) citadas pelos respondentes estão que não há linha de credito do governo especificas para a sustentabilidade e falta comprometimento de todos os envolvidos na cadeia produtiva. Segundo um dos respondentes o Processo AQUA poderia ter sido implantado de maneira eficaz (pergunta 20) se tivessem sido tomadas as decisões em momentos preliminares do projeto. 
Na pergunta (25) sobre como poderia ter sido melhorado o processo de certificação, um dos entrevistados respondeu que seria integrando melhor as fases de projeto e construção. Uma observação feita pelo mesmo entrevistado é que alguns requisitos da certificação demandam evolução do mercado para serem atendidos. Enquanto à pergunta (21) sobre em que medida o Processo AQUA afetou o processo de projeto, execução e produto final, 2 respondentes acharam que o projeto melhorou, um achou que o processo de execução melhorou e um achou que produto final ficou muito melhor.

No que se refere às categorias da certificação, foram analisadas as categorias exigidas pelo AQUA, cujo atendimento se revelaram mais complicadas para as empresas (pergunta 22). $\mathrm{Na}$ resposta a esta questão, os respondentes selecionaram os fatores relevantes que pontuaram numa escala de 1 a 5 , por ordem decrescente de dificuldade (1: Muito fácil; 2: Fácil; 3: Indiferente; 4: Difícil; 5: Muito difícil). A frequência de respostas obtidas para os diversos fatores encontra-se representada na figura 21.

Figura 21: Frequência de respostas das dificuldades dos empreendedores em atingir as categorias exigidas pelo Processo AQUA

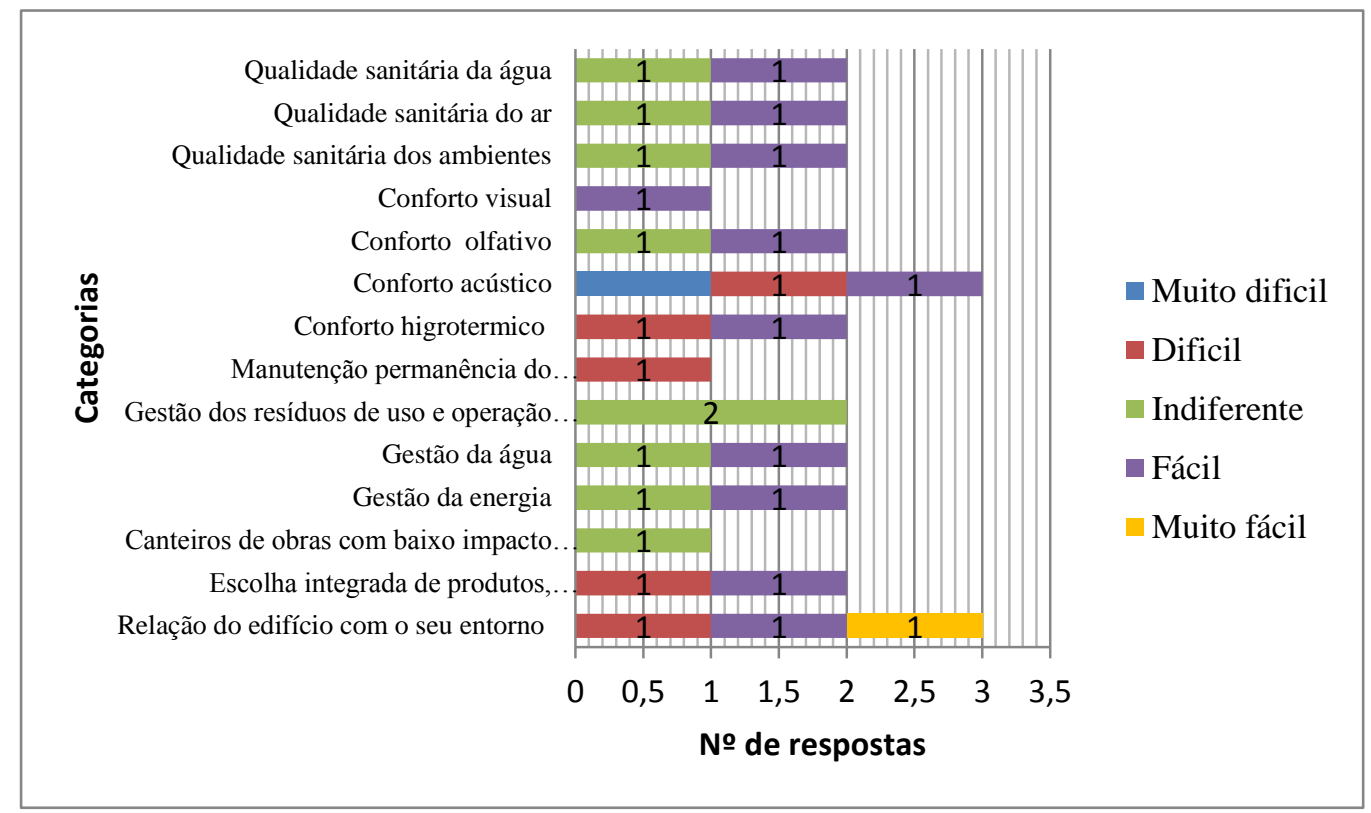

Com base nestes resultados, e admitindo que são relevantes todos os fatores pontuados pelas empresas como 5: Muito difícil e 4: Difícil, procedeu-se então à determinação das dificuldades em atingir as categorias exigidas pelo Processo AQUA (figura 22). 
Figura 22: Dificuldades dos empreendedores em atingir as categorias exigidas pelo

Processo AQUA

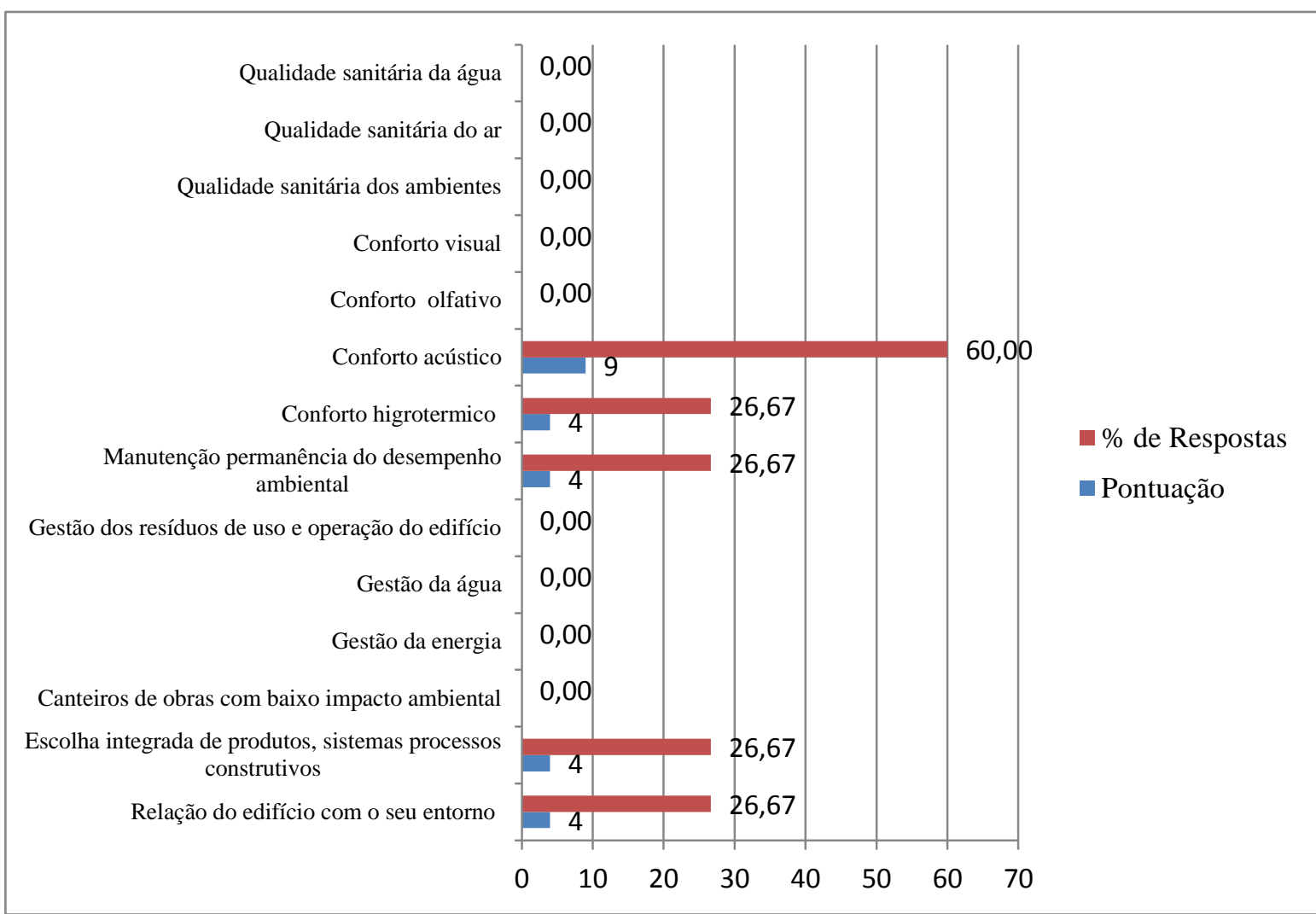

A categoria exigida pelo Processo AQUA mais difícil de se atender refere-se ao "Conforto acústico" (60\%). Seguem-se, depois, o "Conforto higrotermico", a "Manutenção permanência do desempenho ambiental", "Escolha integrada de produtos, sistemas e processos construtivos" e a "Relação do edifício com o seu entorno" (26,67 \%).

\subsection{CONSULTORES}

\subsubsection{PROFESSIONAL LEED AP}

\section{Dados do respondente}

Dos 53 questionários enviados aos profissionais credenciados LEED do Brasil, 8 foram respondidos, o que representa um percentual de aproximadamente $15 \%$ dos respondentes. Os entrevistados foram solicitados a indicar sua função e cargo, 3 eram diretores de projetos, 3 arquitetos, 1 pesquisador e 1 engenheiro. Dois dos entrevistados tinham tempo de experiência na construção de edifícios de 1 a 10 anos e 5 afirmaram ter mais de 10 anos 
de experiência na atividade. 7 dos entrevistados participou de 1 a 10 empreendimentos e um de aproximadamente 20 em processo de certificação e de 6 já certificados.

\section{Dados do empreendimento}

Os usos finais dos edifícios pesquisados foram: Fabrica, Centro cultural, Escritório, Hospital entre outros. Os dados também mostram que 3 dos 8 empreendimentos concluíram o processo certificação. Alguns dos comentários sobre os empreendimentos que não concluíram o processo, foram:

$>$ Os envolvidos, incluindo o proprietário, não entenderam a lógica do processo e, sem nos consultar, tomaram decisões que inviabilizaram a certificação;

$>$ Houve interesse em conhecer o processo e implementar a metodologia de certificação, mas não em certificar o edifício.

Quanto ao nível de certificação do empreendimento, verifica-se que 2 das empresas têm procurado o nível ouro, 3 o nível prata e 2 o nível certificado.

\section{Motivações para a certificação}

No que se refere às motivações, foram analisadas as motivações cuja importância se revelou mais importante para a empresa (pergunta 9). Na resposta a esta questão, os profissionais LEED AP selecionaram um fator sem ponderação. Os resultados obtidos indicam que as motivações mais importantes para obter a certificação foram "Tornar como prioridade a construção sustentável" (2), "Melhorar o resultado final (melhor produto/edifício)" (1), "Melhorar a qualidade de vida de seus ocupantes" (1), "Exigências dos clientes e outras partes interessadas" (1), "Melhoria da imagem" (1) e "Oportunidades de lucro" (1).

Relativamente às motivações para o LEED (pergunta 10), os profissionais LEED AP selecionaram os fatores relevantes que pontuaram numa escala de 1 a 5 , por ordem decrescente de importância (1: Sem importância; 2: Pouco importante; 3: Regularmente importante; 4: Importante; 5: Muito importante). A frequência de resposta obtida para os diversos fatores encontra-se representada na figura 23 . 
Figura 23: Frequência de resposta das motivações dos consultores para a certificação

\section{LEED}

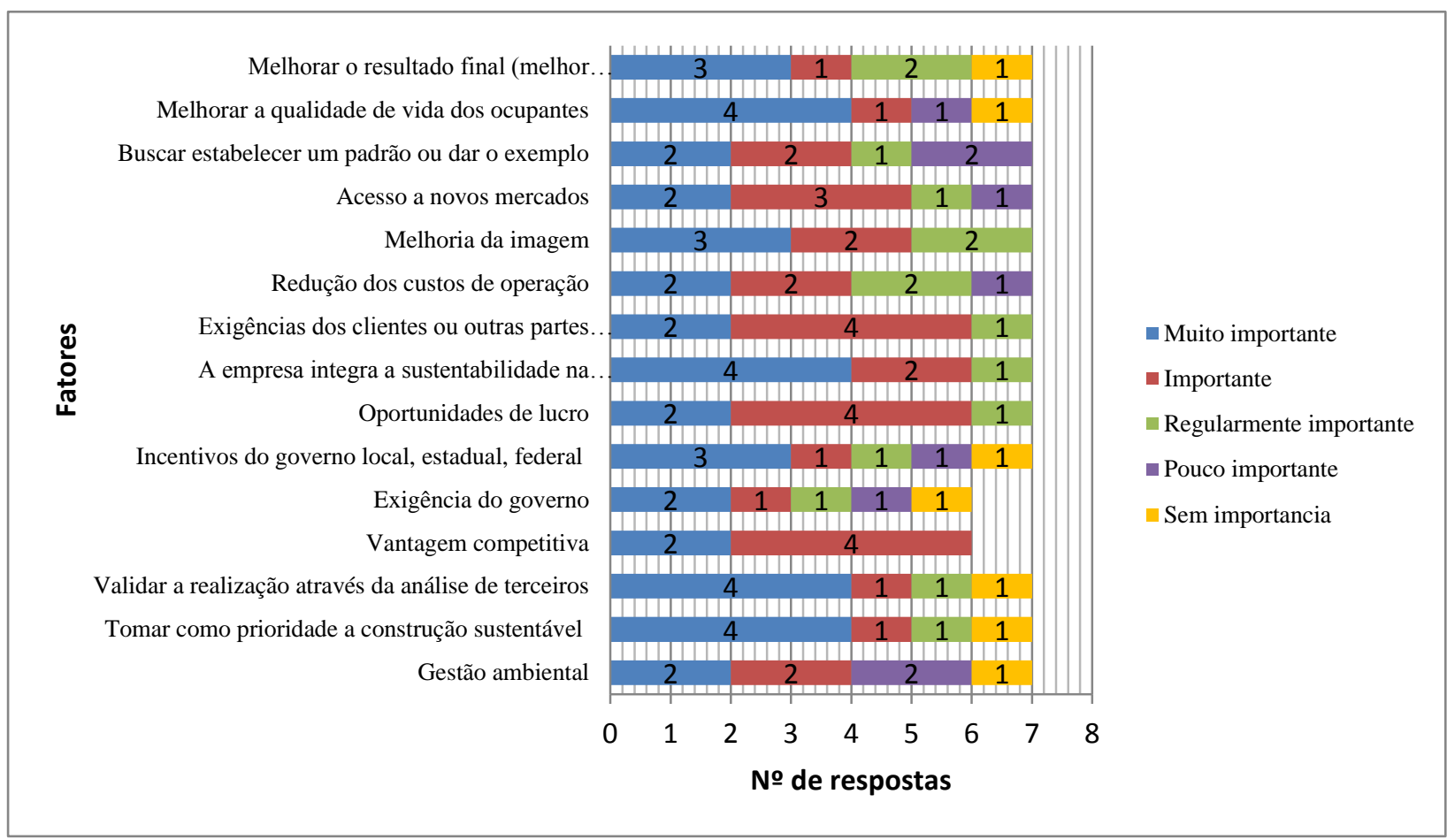

Obs. Nesta pergunta só responderam sete entrevistados inquiridos

Com base nestes resultados, e admitindo que são relevantes todos os fatores pontuados pelas empresas como 5: Muito importante e 4: Importante, procedeu-se então à determinação das dificuldades da implementação do LEED (figura 24).

Figura 24: Motivações dos consultores para a certificação LEED

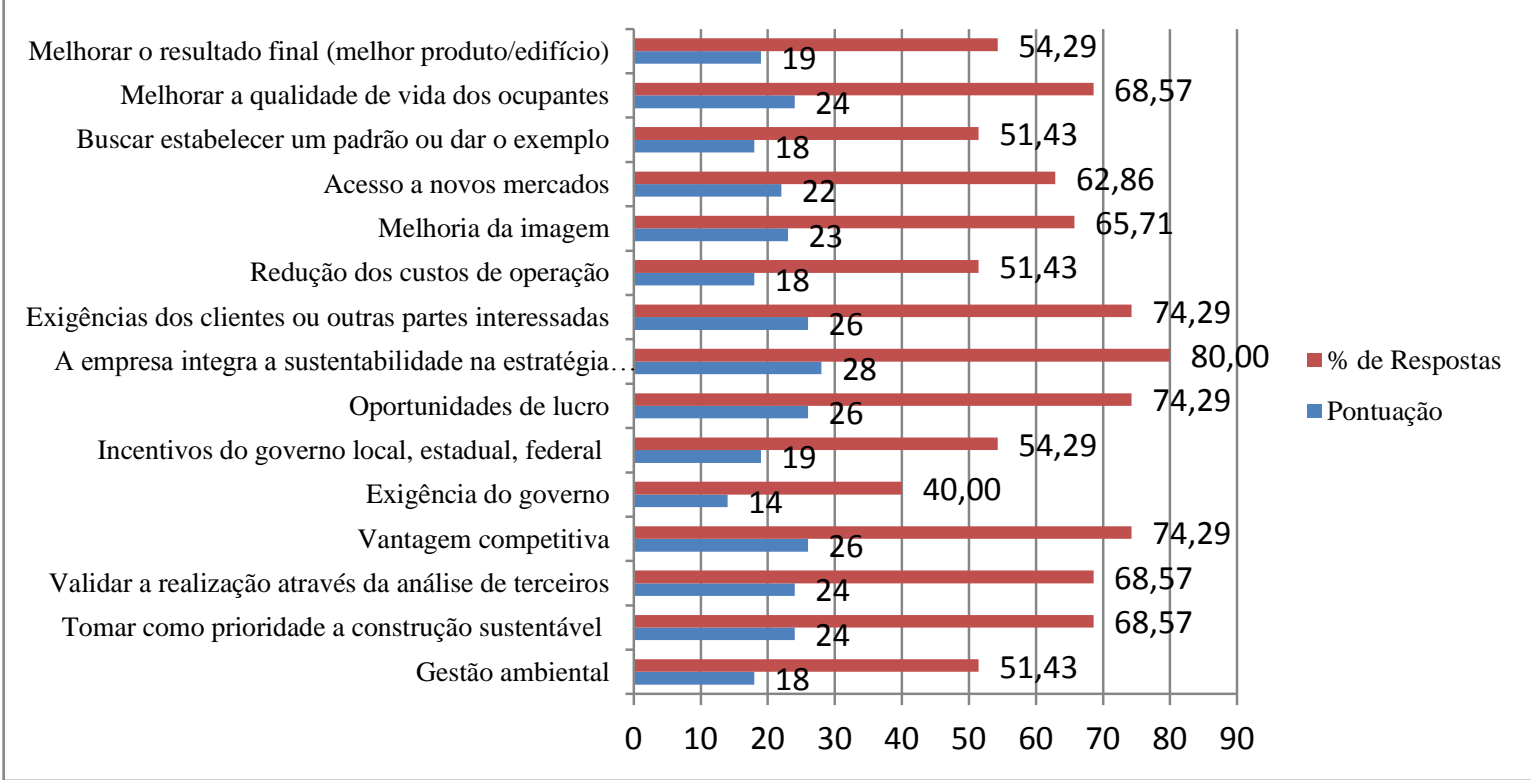


A principal motivação para a certificação LEED é a "A empresa integra a sustentabilidade na estratégia de seus negócios" (80\%), seguindo-se a "Oportunidade de lucro" e

"Exigências dos clientes ou outras partes interessadas" e "Vantagem competitiva" com $(74,29 \%)$ e "Tomar como prioridade a construção sustentável", "Validar a realização através da analise de terceiros", "Melhorar a qualidade de vida dos ocupantes" todas com $(68,57 \%)$ e "Melhoria da imagem" (65,71\%).

Comparando estes resultados com as principais razões identificadas com o estudo de Pardini (2009), verifica-se a coincidência com duas motivações identificadas (formação de uma boa imagem e a atração das multinacionais para estes empreendimentos). Os resultados no que se refere à "Melhoria da imagem" confirmam o pressuposto enunciado por Davies (2005) que refere que para o desenvolvimento de um projeto sustentável as questões relacionadas à imagem da organização estão diante da responsabilidade corporativa ambiental.

Por outro lado, identifica-se coincidência ao se comparar os resultados com as principais razões identificadas no estudo de Johnson (2005), que foi realizado nos EUA, pois a "Preocupação ambiental faz parte dos valores da empresa" foi considerada de igual forma a motivação mais importante.

\section{Benefícios da implementação}

No que se refere aos benefícios, foram analisados os benefícios da obtenção da certificação cuja importância se revelou mais importante para o profissional LEED AP (pergunta 11). $\mathrm{Na}$ resposta a esta questão, os profissionais LEED AP selecionaram um fator sem ponderação. Os resultados obtidos indicam que os benefícios mais importantes para obter a certificação foram "Melhora a qualidade do processo de construção e de seus produtos (empreendimento)" (2), "Mais produtividade, conforto e saúde do usuário" (1), Tornam os empreendimentos mais atraentes o que garante um maior valor agregado" (1), "Publicidade (ganhos em mídia gratuita" (1) e "Imagem, diferenciação e valorização do empreendimento" (1).

No que se referem aos benefícios da implementação do LEED (pergunta 12), os profissionais LEED AP selecionaram os fatores relevantes que pontuaram numa escala de 1 a 5, por ordem decrescente de importância (1: Sem importância; 2: Pouco importante; 3: Regularmente importante; 4: Importante; 5: Muito importante). A frequência de respostas obtidas para os diversos fatores encontra-se representadas na figura 25 . 
Figura 25: Frequência de resposta dos consultores dos benefícios da implementação da certificação LEED

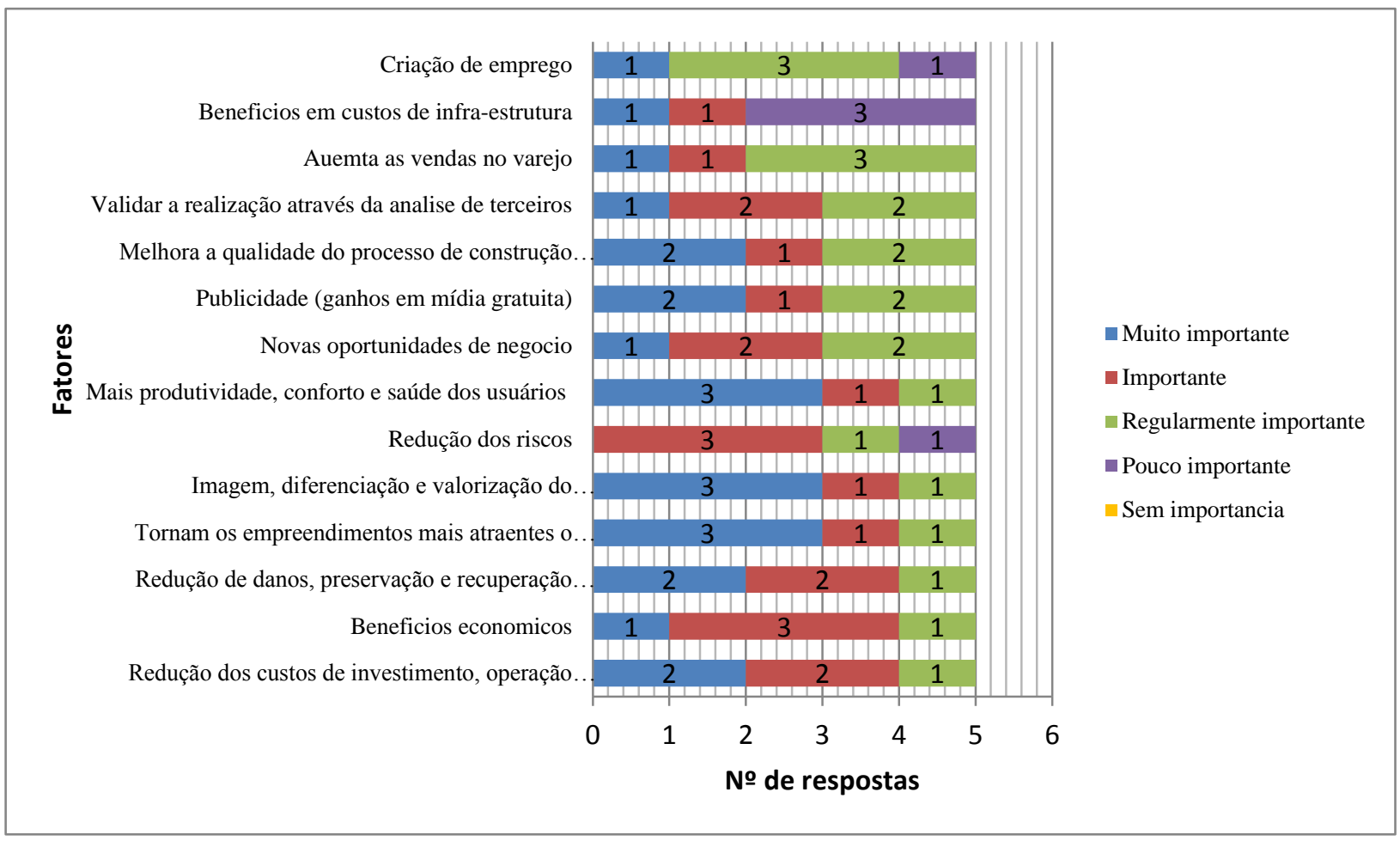

Com base nestes resultados, e admitindo que são relevantes todos os fatores pontuados pelas empresas como 5: Muito importante e 4: Importante, procedeu-se então à determinação dos benefícios da implementação do LEED (figura 26). 
Figura 26: Benefícios da implementação da certificação LEED segundo os consultores

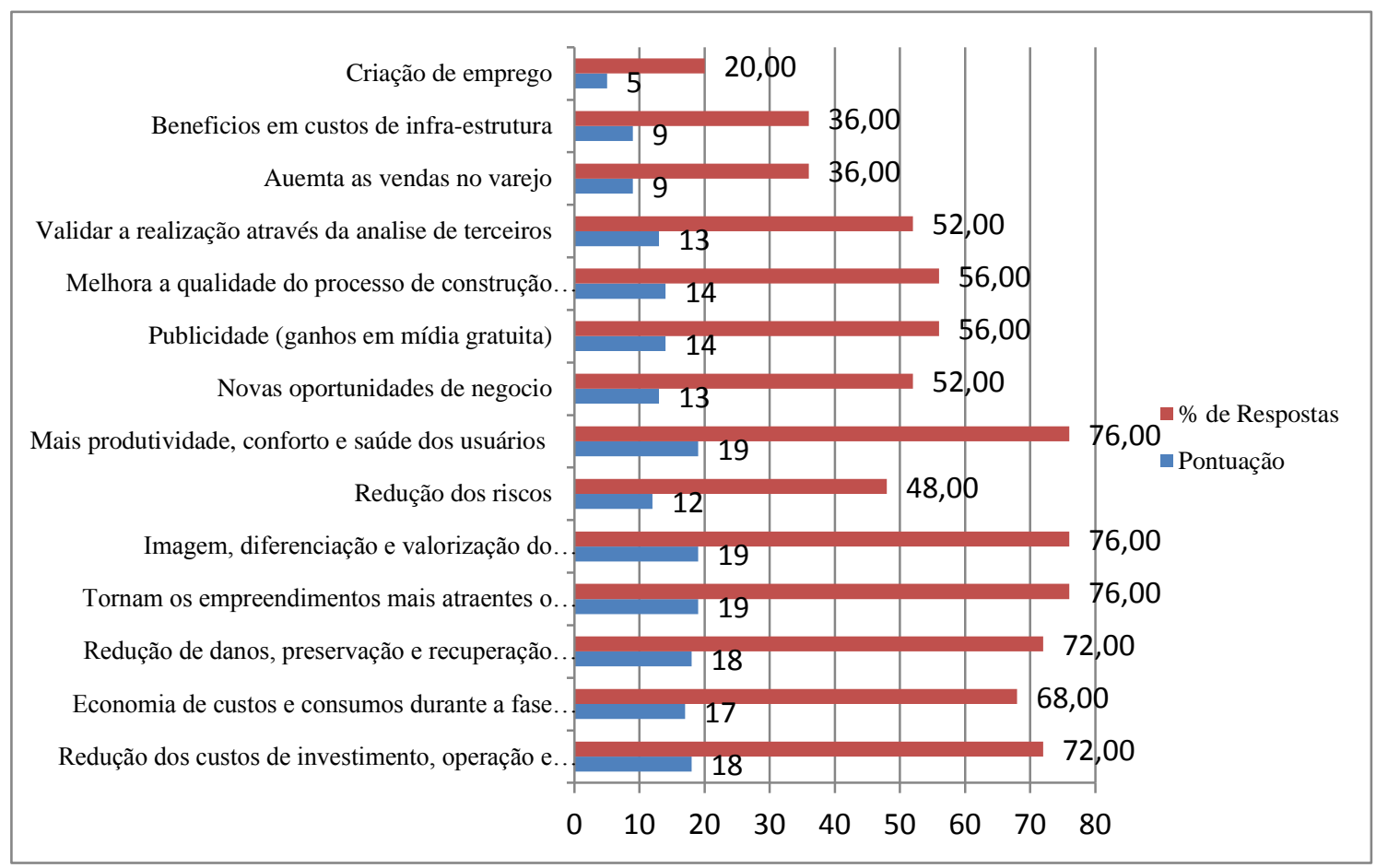

Os principais benefícios encontrados referem-se à "Mais produtividade, conforto e saúde dos usuários", "Imagem, diferenciação e valorização do empreendimento", "Tornam os empreendimentos mais atraentes o que garante maior valor agregado" com 76\%. Seguemse, depois, por ordem decrescente da percentagem de respostas, "Redução dos custos de investimentos, operação de manutenção" e "Redução de danos, preservação e recuperação do meio ambiente" ambas com (72\%), "Economia de custos e consumos durante a fase de construção" (68\%), "Melhora a qualidade do processo de construção e do edifício", "Publicidade", ambas com 56\%.

Em relação ao estudo de McGraw Hill Construction (2005) verifica-se a coincidência de interesses ao nível da saúde e bem-estar, melhorar a produtividade do trabalhador e a criação de valor da construção. Os resultados obtidos no que se refere à "Imagem, diferenciação e valorização do empreendimento" confirmam o pressuposto enunciado por Foster et al. (2000) que refere que a certificação traz reconhecimento e possível valorização da sua reputação. Os resultados deste trabalho sustentam ainda os enunciados de Edwards (1998) e Cryer et al. (2000) que referem que as empresas instaladas em green building obtém benefícios em termos de promover, melhorar ou formar uma imagem de responsabilidade corporativa junto a seus clientes, fornecedores e colaboradores. 


\section{Dificuldades da implementação}

No que se refere às dificuldades, foi analisada a dificuldade para obter a certificação que se revelou mais difícil para o empreendedor (pergunta 13). Na resposta a esta questão, os profissionais LEED AP selecionaram um fator sem ponderação. Os resultados obtidos indicam que as dificuldades mais difíceis para obter a certificação foram a "Falta de comprometimento e empenho dos agentes (projetistas, construtora, etc) com a certificação"(1), "Obter a documentação LEED necessária dos (fornecedores, projetistas, construtora, consultores)" (1), "Pouca integração entre os agentes envolvidos no processo de projeto (cliente, arquiteto, projetistas, construtora, consultores etc.)"(1), "Falta de fornecedores especializados para os insumos (materiais e tecnologias sustentáveis) que o empreendimento demanda ou demandou" (2), "Dificuldade em satisfazer os pré-requisitos do LEED" (1) e "Mudanças do escopo do projeto" (1).

Em relação às dificuldades encontradas no processo de implementação da certificação LEED (pergunta 14), os respondentes selecionaram os fatores relevantes que pontuaram numa escala de 1 a 5, por ordem decrescente de importância (1: Sem dificuldade; 2: Pouco difícil; 3: Regularmente difícil; 4: Difícil; 5: Muito difícil). A frequência de respostas obtidas para os diversos fatores encontra-se representadas na figura 27. 
Figura 27: Frequência de respostas das dificuldades da implementação da certificação LEED segundo os consultores

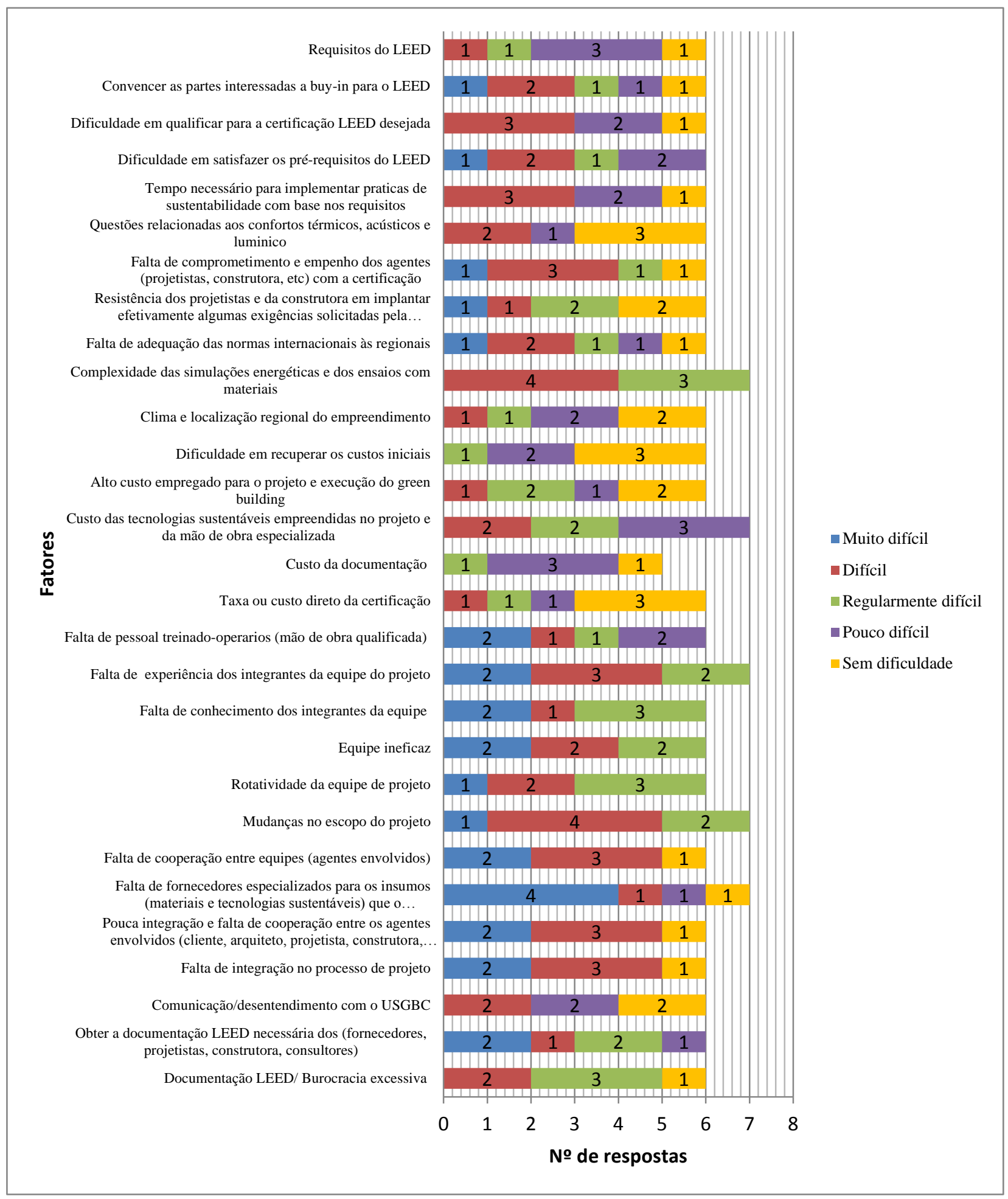

Com base nestes resultados, e admitindo que sejam relevantes todos os fatores pontuados pelos respondentes como 5: Muito difícil e 4: Difícil procedeu-se então à determinação das dificuldades. 
Figura 28: Dificuldades da implementação da certificação LEED segundo os consultores

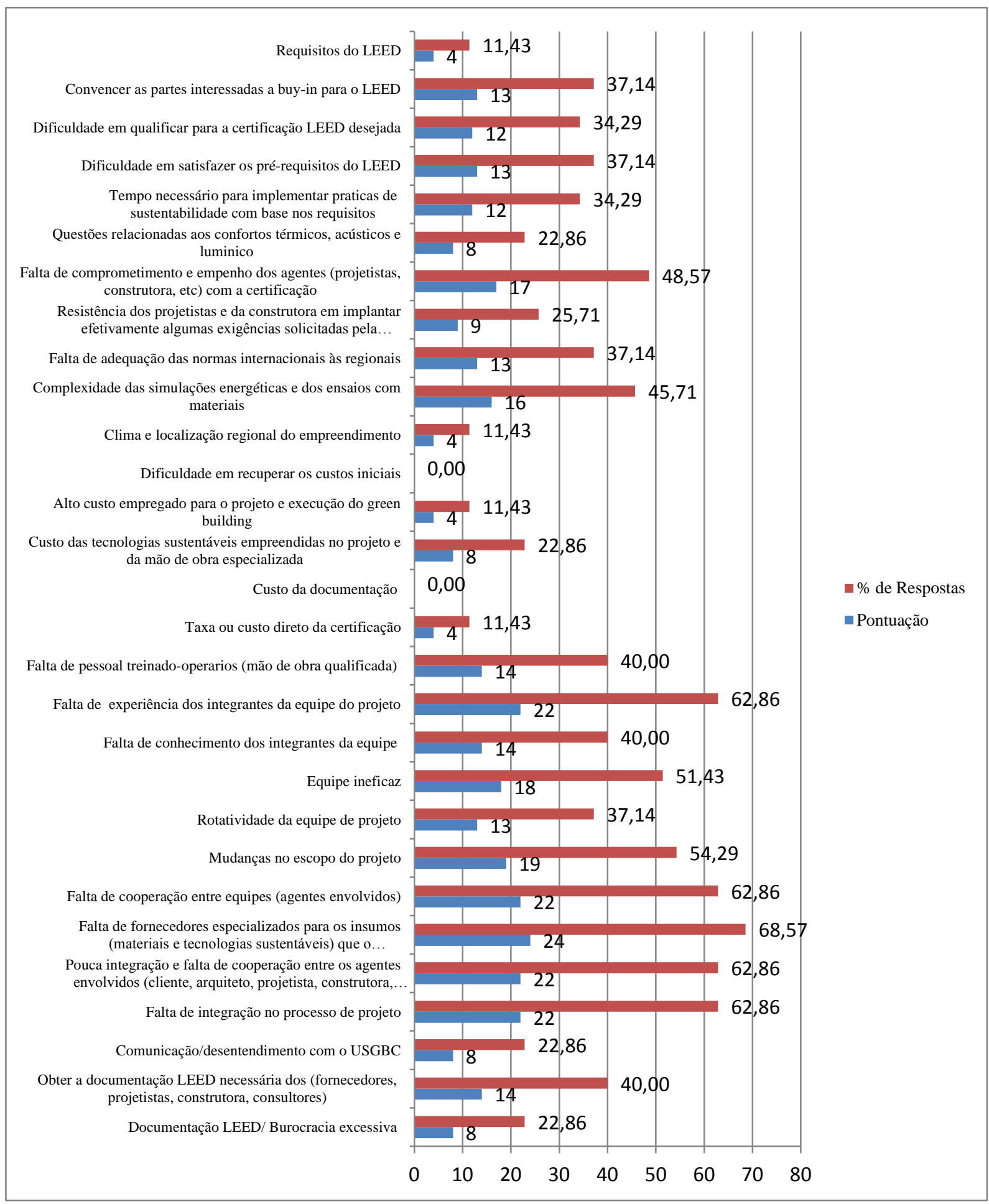

A principal dificuldade encontrada refere-se à "Falta de fornecedores especializados par aos insumos (materiais e tecnologias sustentáveis)" com (68,57\%). Seguem-se, depois, por ordem decrescente da percentagem de respostas a "Falta de experiência dos integrantes da 
equipe de projeto", "Falta de cooperação entre equipes" e "Falta de integração no processo de projeto" todas com $(62,86 \%)$ e o "Equipe ineficaz" $(51,43 \%)$.

Com os resultados obtidos fica evidente a falta de investimento em inovação industrial, em tecnologias sustentáveis e a adaptação da nova cultura da sustentabilidade entre os fornecedores. As outras dificuldades mais importantes são sintomas de ausência de processo de projeto integrado.

Outras dificuldades citadas são relacionadas à:

$>$ Falta de adequação dos agentes envolvidos no processo de gerar de forma eficiente as informações necessárias ao processo de certificação;

$>$ Mudança drástica no processo de uma empresa de construção e projetistas;

$>$ Dificuldade na compreensão da documentação.

\section{Processo de certificação}

A ideia de certificar o empreendimento surgiu do cliente, arquiteto $\mathrm{e}$ proprietário/empreendedor/incorporador (5, 2 e 3 respostas respectivamente). Na maioria dos empreendimentos a certificação foi adotada na fase de concepção do projeto; em 1 empreendimento na fase de programa.

Nas perguntas 18 e 19 que tratam dos custos adicionais estimados pelos profissionais LEED AP, as percepções são distintas, como mostram as respostas e comentários da quadro 7. 
Quadro 7:Percepções do custo adicional da certificação LEED pelos consultores

\begin{tabular}{|c|c|c|}
\hline Empresa & $\begin{array}{l}\text { Percepção do custo adicional } \\
\text { associado à implementação da } \\
\text { certificação LEED }\end{array}$ & $\begin{array}{c}\text { Percepção do custo adicional de } \\
\text { construção em relação ao edifício } \\
\text { convencional }\end{array}$ \\
\hline \multicolumn{3}{|l|}{ E1(Fabrica-Certificado) } \\
\hline E2(Centro cultural-Ouro) & Aprox. R\$30mil & aprox. R\$ 200/250 mil \\
\hline E3(Vários-Prata) & $\begin{array}{l}\text { Ainda não existe esse tipo de } \\
\text { pesquisas no Brasil. Os resultados } \\
\text { obtidos ainda são pouco } \\
\text { representativos pois somente cerca de } \\
30 \text { empreendimentos foram } \\
\text { certificados, de tipologias diferentes } \\
\text { (fábricas, galpões, edifícios de } \\
\text { escritório, etc.). }\end{array}$ & \\
\hline E4(Escritorio-Prata) & $\begin{array}{l}\text { Não saberia informar, não tive acesso } \\
\text { a estes dados. }\end{array}$ & $\begin{array}{l}\text { Não saberia informar, não tive } \\
\text { acesso a estes dados. }\end{array}$ \\
\hline E5 (Prata) & & Hoje, situa-se entre 5 e $10 \%$ \\
\hline E6 (Varios-Prata) & Ainda em andamento & Em andamento \\
\hline E7 (Certificado) & Aprox. 3\% & Aprox. 3\% \\
\hline E8 (Hospital-Ouro) & $\begin{array}{l}\text { Projeto: } 30 \% \\
\text { Consultoria: } 0 \% \text { - foi incorporada ao } \\
\text { projeto } \\
\text { Execução: } 0 \% \\
\text { Certificação: } 0,0003 \% \\
\text { Operações: }-14 \% \text { em energia e }-25 \% \\
\text { em água }\end{array}$ & $\begin{array}{l}\text { Como o hospital já planejava } \\
\text { investir em sistemas que } \\
\text { incorporassem economias na } \\
\text { operação: } 0 \%\end{array}$ \\
\hline
\end{tabular}

O responsável pela documentação para a maioria dos empreendimentos foi o profissional LEED AP com 7 das respostas. Na maioria das empresas os profissionais que trabalharam com o LEED antes de seu envolvimento com o projeto foram o arquiteto (3) e os consultores (3). As partes contratadas que tinham a maioria dos profissionais com conhecimento sobre a certificação LEED foram as de engenharia e consultoria (4 e 5 respectivamente). Na maioria das empresas a documentação foi coordenada por meio de softwares, planilhas Excel e através de papel (5, 4, 3 respectivamente).

Em relação às dificuldades com os projetistas, empresa fiscalizadora, proprietário, empreendedor, fornecedores e construtora (pergunta 22), as mais citadas foram:

$>$ A compreensão do processo que tem como premissa a mudança na forma convencional de se desenvolver projetos e se construir;

$>$ Os projetistas e consultores têm dificuldade de alterar as suas metodologias de trabalho;

$>$ A certificação exige alguns documentos e cálculos que normalmente não são elaborados em projetos convencionais; 
$>$ Fazer com que as melhores coisas saiam do papel, e que se leve as boas intenções até o fim.

$>$ Entender os requerimentos;

$>$ Justificar custos adicionais gerados pelo processo e pelas especificações da certificação LEED;

$>$ Educar os construtores;

$>$ Preenchimento da documentação pela construtora, em inglês.

No que diz respeito às maiores dificuldades em relação à documentação exigida pelo LEED (pergunta 24), os profissionais LEED AP informam que são:

$>$ A língua, pois ter que traduzir tudo é bem trabalhoso;

$>$ Encontrar nos produtos brasileiros as informações solicitadas pelo LEED;

$>$ Ter a colaboração dos projetistas e construtores nesta tarefa;

$>$ Alguns itens de construção sustentável que formalmente não são solicitados pela norma são rejeitados;

$>$ Cálculos e memoriais para comprovação/evidencias;

$>$ Entender a documentação necessária e em segundo lugar o volume de tradução e conversão de unidades;

$>$ Gerar documentos que atendam as especificações junto a fornecedores;

> Metodologia de apresentação dos cálculos de renovação de ar, de ASHRAE 62.1, para o projeto.

Em relação às barreiras internas foram mencionadas a falta de planejamento e mau gerenciamento, dificuldades no relacionamento com os fornecedores, falta de treinamento e adequação aos requerimentos do LEED. Quanto às barreiras externas foi mencionada a cultura imediatista e as altas taxas de juros.

Na pergunta 27, relacionada à como poderia ter sido implantada a certificação LEED de maneira eficaz, as respostas foram iniciar o processo desde a concepção do projeto e maior comprometimento dos envolvidos.

Foi solicitado a cada um dos profissionais inquiridos apontarem em que medida a certificação LEED afetou as etapas do empreendimento projeto, execução e produto final, 
em uma pergunta de tipo escala de Likert que foi codificada de 1 a 5 (1:Muito pior; 2:Pior; 3:Similar; 4: Melhor; 5:Muito melhor).

Figura 29: Frequência de respostas dos consultores relacionadas às etapas do empreendimento afetadas pela certificação LEED

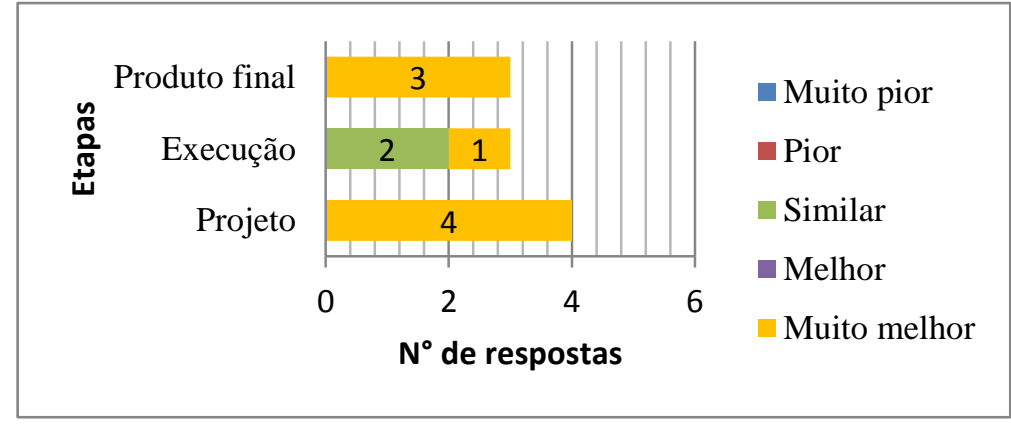

Os resultados obtidos indicam que 4 dos 8 respondentes encontram que a certificação LEED afetou o projeto para "Muito melhor" e 3 respondentes encontram que a certificação LEED afetou o produto final para "Muito melhor".

No que se refere às categorias da certificação LEED, foram analisadas tendo em vista seu grau de importância no projeto. Na resposta a esta questão, os respondentes selecionaram os fatores mais relevantes que pontuaram numa escala de 1 a 5 , por ordem decrescente de importância (5: Muito importante; 4: Importante; 3: Regularmente importante; 2: Pouco importante; 1: Sem importância). A frequência das respostas obtidas para os diversos fatores encontra-se representadas na figura 30.

Figura 30: Frequência das respostas dos consultores das categorias relevantes da certificação LEED

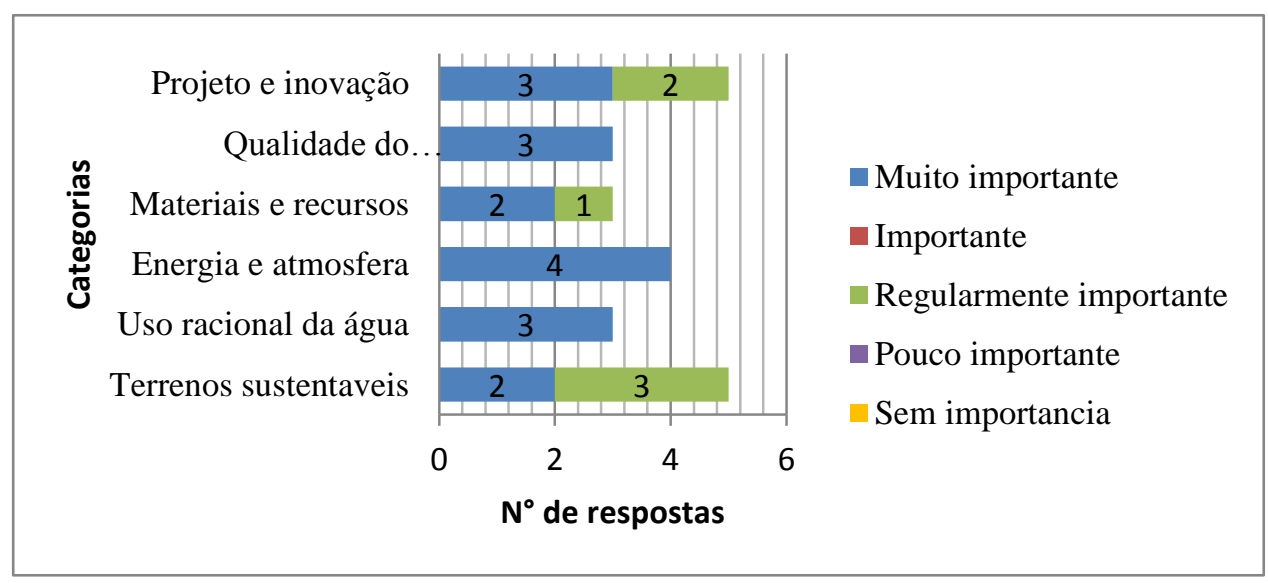


O resultado desta analise revela que a categoria "Energia e atmosfera" é a mais utilizada seguem-se o "Projeto e inovação", a "Qualidade do ambiente interno" e o "Uso racional da água".

No que se refere às categorias da certificação LEED, foram analisadas tendo em vista seu grau de dificuldade no projeto.Na resposta a esta questão, os respondentes selecionaram os fatores mais difíceis que pontuaram numa escala de 1 a 5 , por ordem decrescente de importância (1: Muito fácil; 2: Fácil; 3: Indiferente; 4: Difícil; 5: Muito difícil). A frequência de respostas obtidas para os diversos fatores encontra-se representadas na figura 31.

Figura 31: Categorias mais difíceis de alcançar da certificação LEED segundo os consultores

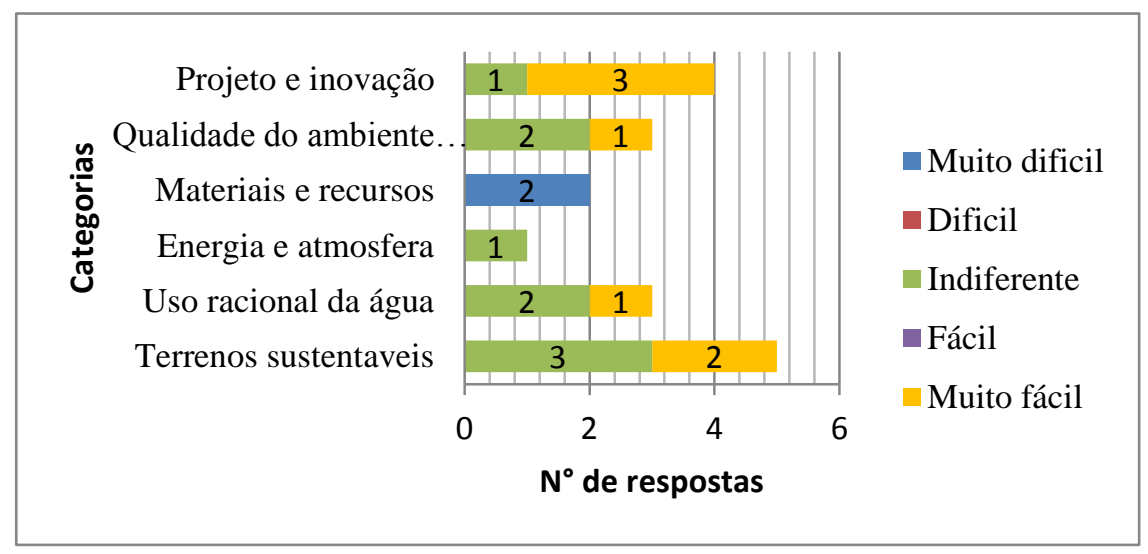

No que diz respeito ao grau de dificuldade em atingir as categorias exigidas pelo LEED, os resultados indicam que "Materiais e recursos", foram a mais difícil.

No que se refere às categorias da certificação LEED que geram atraso na obra. Na resposta a esta questão, os respondentes selecionaram os fatores que atrasam e pontuaram numa escala de 1 a 5, por ordem decrescente de importância (1: Muito atraso; 2: Atraso; 3: Indiferente; 4: Pouco atraso; 5: Não atraso). A frequência de respostas obtidas para os diversos fatores encontra-se representadas na figura 32. 
Figura 32: Categorias da certificação LEED que geram atraso na obra segundo os consultores

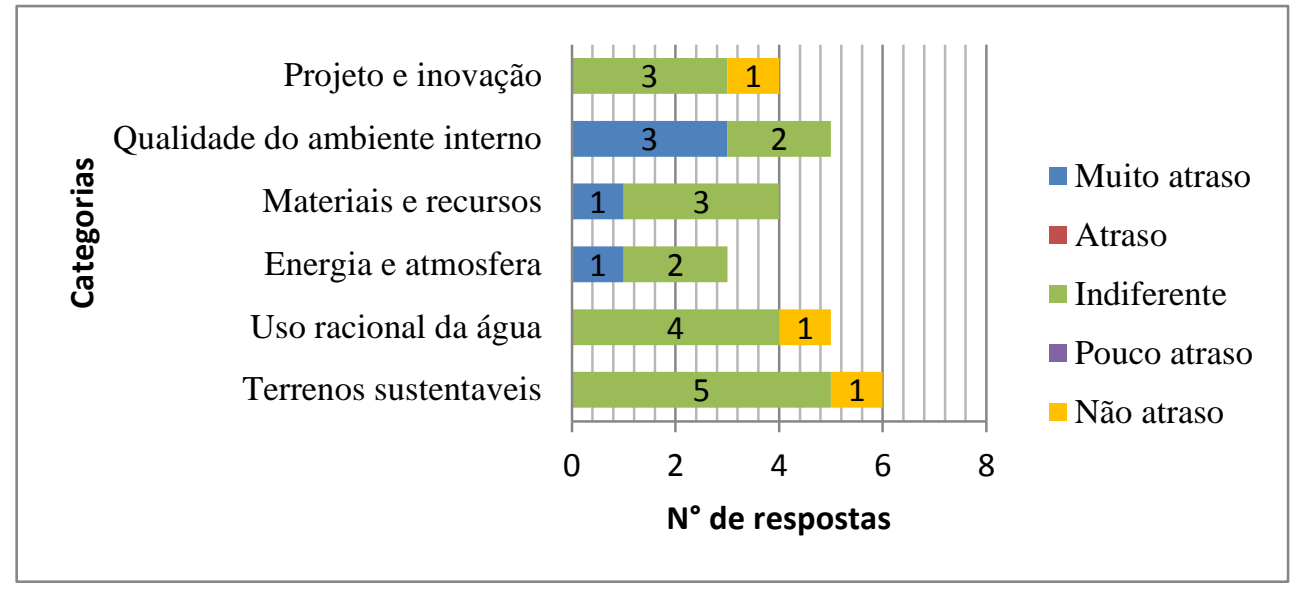

As categorias que geram mais atraso durante o projeto e a obra foram "Qualidade do ambiente interno", a "Energia e atmosfera" e "Materiais e recursos" (com 3,1,1 respectivamente).

\section{Evolução da certificação}

Os profissionais inquiridos quando confrontados com a forma como poderia ser melhorado o processo de certificação LEED, selecionaram um número limitado de fatores sem qualquer ponderação. Os resultados obtidos indicam que deveria de "Integrar se melhor as fases de projeto e de construção" (3), "Menos burocracia/ interface on-line" (2), e "Simplificar a documentação e certificação" (2). Os comentários dos inquiridos sobre como melhorar o processo foram que deveria haver uma nacionalização da norma e melhor capacitação e treinamento dos envolvidos.

\subsubsection{CONSULTOR DO PROCESSO AQUA}

\section{Dados do respondente e do empreendimento}

O entrevistado desempenha o cargo de analista ambiental e tem um ano de experiência em construção de edifícios nos quais já tem participado em 4 empreendimentos certificados. $\mathrm{O}$ empreendimento foi certificado nas fases programa, concepção e realização. A ideia de certificar este empreendimento surgiu do proprietário. 


\section{Motivações para a certificação}

A principal motivação apontada para obter as certificações do Processo AQUA foi tornar como prioridade a construção sustentável. Em relação às principais motivações encontradas para a certificação com o Processo AQUA, foram apontadas a "gestão ambiental", "Vantagem competitiva", "Oportunidade de lucro", "A empresa integra a sustentabilidade na estratégia de seus negócios", "Exigências dos clientes e outras partes interessadas", "Redução dos custos de operação", "Melhoria da imagem", "Acesso a novos mercados", "Melhorar a qualidade de vida dos ocupantes", "Melhorar o resultado final", "Redução dos custos operacionais e de manutenção", "Benefícios econômicos", "Redução de danos, preservação e recuperação do meio ambiente".

\section{Benefícios da implementação}

O beneficio mais importante para a obtenção da certificação foi "Mais produtividade, conforto e saúde do usuário". Os principais benefícios encontrados da implementação do Processo AQUA referem-se à "Redução dos custos operacionais e de manutenção", "Benefícios econômicos", "Redução de danos, preservação e recuperação do meio ambiente", "Imagem diferenciação e valorização do empreendimento", "Redução dos riscos", "Novas oportunidades de negócios", "Publicidade (ganhos em mídia gratuita)", "Melhora a qualidade do processo de construção e de seus produtos" e "Validar a realização através da analise de terceiros”.

\section{Dificuldades da implementação}

A maior dificuldade para obter a certificação foram as questões relacionadas aos confortos térmico, acústico e luminico. Isto pode ser devido a que a busca de soluções criativas para os confortos é limitada e pouco explorada Em relação as dificuldade mais difíceis da implementação do Processo AQUA, o entrevistado indicou a "Falta de integração no processo de projeto", "Pouca integração entre os agentes envolvidos no processo de projeto", "Falta de cooperação entre equipes". 


\section{Processo de certificação}

Começou-se a buscar informações sobre a certificação já na fase de programa. A principal dificuldade encontrada para implementar o SGE está na mudança de comportamento, incorporação de conceitos e rotinas, cujos envolvidos não estão acostumados. "Porém, esta é uma tendência que está mudando, visto que estamos nos sentindo cada vez mais envolvidos com as exigências da certificação”. Já a maior dificuldade encontrada ao longo do processo de implementação do Processo AQUA, está relacionada à falta de dados correspondentes às características ambientais dos produtos e materiais adotados, pois a declaração ambiental de produtos ainda é bastante escassa.

Os que trabalharam com o Processo AQUA antes de seu envolvimento com o projeto foram o arquiteto e o empreendedor. A empresa contratou os serviços de uma empresa de consultoria. Os responsáveis do fluxo de informações e de estruturar os documentos exigidos pelo processo AQUA foram o arquiteto e o empreendedor. A documentação foi coordenada em planilhas de Excel e em papel. As maiores dificuldades em relação à documentação exigida pelo Processo AQUA foram: comprovar a qualidade ambiental de alguns materiais e a documentação relacionada aos controles para rastreabilidade dos resíduos (comprovantes de transporte e legalidade das empresas receptoras). A barreira interna para a implementação do Processo AQUA foi à falta de envolvimento de todos participantes. Se os envolvidos não estiverem realmente satisfeitos com o processo de certificação, o processo é prejudicado. A barreira externa foi à dificuldade de consulta de algumas informações.

As categorias consideradas mais importantes no projeto foram: a "Escolha integrada de produtos, sistemas e processos construtivos", “Canteiros de obras com baixo impacto ambiental”, “Gestão da energia”, “ Gestão da água”, "Gestão dos resíduos de uso e operação do edifício", "Manutenção permanência do desempenho ambiental”, “ Conforto higrotermico", “Conforto acústico”, “ Conforto olfativo”, “ Conforto visual”, “Qualidade sanitária dos ambientes”, “Qualidade sanitária do ar”, “Qualidade sanitária da água”.

As categorias do Processo AQUA mais difíceis de atingir foram: a "Escolha integrada de produtos, sistemas e processos construtivos", "Canteiros de obras de baixo impacto ambiental”, “ Manutenção permanência do desempenho ambiental”. Já as categorias do 
Processo AQUA que demandaram maior cuidado no projeto e obra foram: a "Escolha integrada de produtos, sistemas e processos construtivos", "Canteiros de obras de baixo impacto ambiental”, "Gestão da energia", "Gestão da água”, "Manutenção permanência do desempenho ambiental", "Conforto higrotermico", "Conforto acústico", "Conforto olfativo”, “ Conforto visual”, “ Qualidade sanitária do ar”, “Qualidade sanitária da água”.

\section{Evolução da certificação}

Em relação a como poderia ser melhorado o processo de certificação o entrevistado sugeriu que deveria haver "Menos burocracia/ interface on-line", "Simplificar a documentação e certificação", "Integrar melhor as fases de projeto e de construção" e "Melhorar o atendimento ao cliente e feedback". Com relação a quanto o Processo AQUA pode afetar o projeto, a execução e o produto final o entrevistado indicou que a certificação melhorou todas as fases da construção. 


\section{CONCLUSÕES E RECOMENDAÇÕES}

\subsection{CONCLUSÕES}

Após a análise critica dos resultados dos questionários podem-se organizar as conclusões em dois grupos diferentes (quadro 8 e 9) ligados às certificações Processo AQUA e LEED, que estão subdivididas de acordo com os objetivos da pesquisa. Inicialmente, podese afirmar que os dois grupos de empreendedores e consultores enxergam de maneira diferente as certificações, ainda que tenham sido encontrados alguns pontos em comum.

\section{PROCESSO AQUA}

Quadro 8: Principais motivações, benefícios e dificuldades da implementação do Processo

\section{AQUA}

\begin{tabular}{|c|c|c|}
\hline & Empreendedores do Processo AQUA & Consultores do Processo AQUA \\
\hline \multirow{6}{*}{ Motivações } & Melhorar o resultado final & Tornar como prioridade a construção sustentável \\
\hline & $\begin{array}{l}\text { Melhoria da qualidade de vida dos } \\
\text { ocupantes }\end{array}$ & \\
\hline & $\begin{array}{l}\text { Buscar estabelecer um padrão ou dar o } \\
\text { exemplo }\end{array}$ & \\
\hline & $\begin{array}{l}\text { A empresa emprega a sustentabilidade } \\
\text { na estratégia de seus negócios }\end{array}$ & \\
\hline & $\begin{array}{l}\text { Tornar como prioridade a construção } \\
\text { sustentável }\end{array}$ & \\
\hline & Gestão ambiental & \\
\hline \multirow{3}{*}{ Benefícios } & $\begin{array}{l}\text { Redução de danos, preservação e } \\
\text { recuperação do meio ambiente }\end{array}$ & \\
\hline & $\begin{array}{l}\text { Mais produtividade, conforto e saúde do } \\
\text { usuário }\end{array}$ & Mais produtividade, conforto e saúde do usuário \\
\hline & $\begin{array}{l}\text { Redução dos custos operacionais e de } \\
\text { manutenção }\end{array}$ & \\
\hline \multirow{4}{*}{ Dificuldades } & $\begin{array}{l}\text { Convencer as partes interessadas a buy- } \\
\text { in para o Processo AQUA }\end{array}$ & $\begin{array}{l}\text { Questões relacionadas aos confortos térmico, } \\
\text { acústico e luminico }\end{array}$ \\
\hline & $\begin{array}{l}\begin{array}{l}\text { Dificuldade em recuperar os custos } \\
\text { iniciais }\end{array} \\
\end{array}$ & Falta de integração no processo de projeto \\
\hline & $\begin{array}{l}\text { Escassez de fornecedores especializados } \\
\text { para os insumos }\end{array}$ & $\begin{array}{l}\text { Pouca integração entre os agentes envolvidos no } \\
\text { processo de projeto }\end{array}$ \\
\hline & & Falta de cooperação entre as equipes \\
\hline
\end{tabular}




\section{CERTIFICAÇÃO LEED}

Quadro 9: Principais motivações, benefícios e dificuldades da implementação da certificação LEED

\begin{tabular}{|c|c|c|}
\hline & Empreendedores LEED & Profissional LEED AP \\
\hline \multirow{5}{*}{ Motivações } & Melhoria da imagem & $\begin{array}{l}\text { A empresa emprega a sustentabilidade na } \\
\text { estratégia de seus negócios }\end{array}$ \\
\hline & Oportunidades de lucro & Oportunidades de lucro \\
\hline & Melhorar o resultado final & $\begin{array}{l}\text { Exigências dos clientes ou de outras partes } \\
\text { interessadas }\end{array}$ \\
\hline & Acesso a novos mercados & Vantagem competitiva \\
\hline & Vantagem competitiva & \\
\hline \multirow{3}{*}{ Benefícios } & $\begin{array}{l}\text { Imagem, diferenciação e valorização } \\
\text { do empreendimento }\end{array}$ & Mais produtividade, conforto e saúde do usuário \\
\hline & $\begin{array}{l}\text { Tornam os empreendimentos mais } \\
\text { atraentes o que garante maior valor }\end{array}$ & $\begin{array}{l}\text { Imagem, diferenciação e valorização do } \\
\text { empreendimento }\end{array}$ \\
\hline & Novas oportunidades de negócios & $\begin{array}{l}\text { Tornam os empreendimentos mais atraentes o que } \\
\text { garante maior valor }\end{array}$ \\
\hline \multirow{4}{*}{ Dificuldades } & $\begin{array}{l}\text { Obter a documentação LEED } \\
\text { necessária dos fornecedores, } \\
\text { projetistas, construtora e consultores }\end{array}$ & $\begin{array}{l}\text { Falta de fornecedores especializados para os } \\
\text { insumos }\end{array}$ \\
\hline & $\begin{array}{l}\text { Documentação } \\
\text { excessiva }\end{array}$ & $\begin{array}{l}\text { Falta de experiência dos integrantes da equipe de } \\
\text { projeto }\end{array}$ \\
\hline & $\begin{array}{l}\text { Falta de fornecedores especializados } \\
\text { para insumos }\end{array}$ & Falta de cooperação entre os agentes envolvidos \\
\hline & & Falta de integração no processo de projeto \\
\hline
\end{tabular}

Após a sistematização apresentada, podemos observar os seguintes pontos:

$>$ A melhoria da imagem da empresa, oportunidades de lucro, vantagem competitiva e melhoria do resultado final são os fatores principais que levam aos empreendedores a buscar a certificação LEED. Isto reflete uma busca da certificação LEED para trazer vantagens para a empresa. Enquanto os empreendedores que procuram as certificações do Processo AQUA buscam demonstrar a responsabilidade ambiental da empresa e trazer vantagens para os usuários e para o empreendimento.

$>$ A maior produtividade e conforto e saúde dos usuários foi o beneficio mais apontado pelos consultores (LEED e Processo AQUA). Isto demonstra que a certificação representa a preocupação do consultor em procurar instalações funcionais e adequadamente dimensionadas, porque é bom para o usuário final.

$>$ Os empreendedores, em comparação aos consultores, não destacam a questão da falta de processo de projeto integrado (PPI) como uma dificuldade. Este indicador 
reflete que os empreendedores estão mais preocupados em resolver outras dificuldades, como recuperar os custos, encontrar fornecedores e obter a documentação necessária. Eles não percebem que a falta de PPI causa dificuldades para o atendimento às demandas da certificação, na falta de integração e colaboração entre a equipe de trabalho, na consulta de algumas informações, na falta de planejamento e mau gerenciamento e em relação à documentação exigida pelo LEED. Nesse sentido, para que estas dificuldades sejam minimizadas e evitadas é necessária a incorporação de elementos metodológicos que caracterizam o PPI.

$>$ Os resultados mostram que as questões de conforto térmico, acústico e luminico são difíceis de serem atendidos. Esse dado demonstra que atender os requisitos de conforto é um desafio às empresas, especificamente para aquelas que não querem aumentar os custos da construção buscando um beneficio mediático e não o beneficio do usuário que, a longo prazo, é o único beneficiado. Outra razão é que para conseguir um conforto térmico, acústico e luminico é necessário fazer simulações, estudos e pesquisas no mercado na procura de soluções de arquitetura e construtivas, compatibilização de projetos e não há muita mão de obra qualificada. Outro ponto a ser observado é a diminuição da qualidade espacial, trazendo consigo excessivo uso de ar acondicionado, espaços cada vez mais herméticos, pequenos e desconfortáveis reduzindo o volume de ar e ventilação natural.

$>$ Os resultados mostram que as empresas recorrem ao apoio da consultadoria para a implementação das certificações. Este resultado, para além de demonstrar, em alguns dos casos, a ausência de capacidades internas para assegurar a certificação de forma independente, permite constatar que o processo de certificação é tão complexo que não dispensa a colaboração de especialistas externos ou que, eventualmente, as empresas não estão interessadas em dispor de peritos internos que possam desenvolver esses projetos. Isto poderá significar que as empresas embora interessadas em aumentar a sua competitividade e obter uma maior produtividade, conforto e saúde dos usuários, não investem de uma forma global na satisfação de suas necessidades em matéria de ambiente. 
$>$ Em relação às principais dificuldades encontradas na implementação das certificações ambientais para edifícios (LEED e Processo AQUA), foi observado que a "falta de fornecedores de produtos e serviços sustentáveis para construção" foi um dos principais obstáculos encontrados pelos respondentes (empreendedores e consultores). Cada vez mais os fornecedores nacionais e internacionais estão focados em criar produtos e processos que causem menos impacto ao meio ambiente. Apesar desse esforço, ainda há escassez de fornecedores de materiais e produtos devido a: falta de demanda por parte do mercado, os fornecedores vislumbram desvantagens comerciais e econômicas, pouco apoio institucional a pesquisas sobre materiais sustentáveis, desconfiança e rejeição por materiais e produtos sustentáveis por parte do construtor e do usuário. Por outro lado, também influencia a falta de consciência da necessidade de substituir materiais nocivos ao equilíbrio dos diversos ecossistemas, em todo seu ciclo de vida, por outros de menor impacto e desinteresse dos fornecedores neste tipo de materiais e produtos porque é mais econômico para a construtora compara produtos tradicionais, pois são fabricados em massa, enquanto os materiais e produtos sustentáveis são mais caros e fabricados em pequena escala.

$>$ A falta de dados e informações em relação aos produtos e materiais sustentáveis e a dificuldade em comprovar a qualidade ambiental de alguns materiais no Brasil são entraves para a especificação e uso dos mesmos. Tais problemas podem ser derivados da falta de unificação dos fornecedores de materiais em certificar a qualidade ambiental de seus produtos, da irregularidade na atividade de produção do material, da falta de adequada gestão da produção, da falta de conhecimentos sobre técnicas de produção mais adequadas e de documentos normativos. Assim, por outro lado, esses problemas também podem derivar da dificuldade em obter assistência técnica qualificada, das perdas de materiais e energia, a falta de controle ambiental sobre o processo de fabricação dos materiais e produtos por parte de entes ambientais e da divulgação de informações por fabricantes e fornecedores com caráter propagandístico o que acaba se tornando um risco na veracidade dos conteúdos expostos. 


\subsection{RECOMENDAÇÕES}

Os sistemas de avaliação ambiental de edifícios (LEED e Processo AQUA) tem potencial de implementar melhores praticas sustentáveis no setor. Contudo, e para resolver alguns obstáculos relativos à adoção de sistemas de avaliação ambiental de edifícios que foram identificados ao longo deste trabalho, apresenta-se, a seguir, um conjunto de recomendações, destinadas a facilitar este processo, que poderão ser empreendidas pelas empresas, pelos organismos de certificação e pelas autoridades governamentais competentes:

Com o intuito de melhorar o processo de implementação da certificação (LEED e Processo AQUA) sugerem-se as seguintes possibilidades:

$>$ Maior integração do projeto e construção;

$>$ Tomar as decisões em momentos preliminares do projeto;

$>$ Iniciar o processo de certificação desde a concepção do projeto com o comprometimento dos envolvidos;

$>$ Criar uma cultura na a equipe de trabalho com temas relacionados a edifícios sustentáveis, certificação e processo de projeto integrado;

$>$ Integrar a certificação e a adoção de materiais e tecnologias desde o projeto até a execução do edifício;

$>$ Desenvolver procedimentos internos para simplificar a apresentação e gestão da documentação da certificação;

$>$ Iniciar o processo de documentação o mais cedo possível, certificando-se que empreiteiros e fornecedores compreendam a documentação necessária.

Com o objetivo de satisfazer a necessidade de mais e melhor informação por parte das empresas construtoras relativamente à implementação e à melhoria do processo de certificação e de potenciar a obtenção da certificação (LEED e Processo AQUA) sugeremse as seguintes possibilidades de desenvolvimento para a intervenção nos organismos de certificação:

> Prever a elaboração de manuais de apoio à implementação das certificações, incluindo, casos práticos de implementação das certificações (LEED e Processo 
AQUA) bem sucedidas (incluindo sugestões para identificar e melhorar as áreas que parecem ser mais difíceis);

$>$ Preparar um guia para compreender o processo de documentação necessária para a certificação;

$>$ Valorizar a marca "Edifício sustentável certificado" e promover, com maior visibilidade, os edifícios que obtiveram a certificação ambiental;

$>$ Sensibilizar as autoridades governamentais para a necessidade de adequação das normas e legislação à realidade do mercado e conjuntura atuais;

$>$ Estudar a possibilidade de vir a desenvolver, em estreita articulação com as referidas entidades (GBC Brasil e FCAV), planos de formação específicos para os diferentes atores da cadeia da construção civil com o objetivo de sensibilizar para a maior valorização das certificações ambientais de edifícios (LEED e Processo AQUA) e green buildings;

$>$ Criar e gerenciar relações com instituições e escolas de ensino;

$>$ Simplificar o processo de certificação e documentação necessária para a certificação;

$>$ Diminuir a burocracia no processo de certificação;

$>$ Melhorar o atendimento ao cliente.

Com a intenção de potencializar a obtenção da certificação em edifícios e de promover as construções sustentáveis, sugere-se ainda o desenvolvimento das seguintes ações por parte das autoridades governamentais competentes:

$>$ Valorizar as edificações e projetos sustentáveis nos critérios de apreciação das propostas apresentadas em concursos públicos;

$>$ Criar legislações locais que por meio de incentivos (créditos fiscais e consultores patrocinados pelo governo) e exigências de requisitos mínimos de sustentabilidade para edificações, insumos e componentes, movimente toda a cadeia produtiva da construção e torne mais familiar o processo de certificação;

$>$ Criar prêmios que possam promover e divulgar a adoção das certificações e green buildings melhorando a consciencialização pública sobre a temática;

$>$ Criar Institutos verdes ou redes de cooperação, para dar suporte à disseminação das edificações sustentáveis e à criação de sinergias organizacionais que objetivem a 
criação de redes locais de empresas da construção civil e a criação de programas de capacitação em escolas técnicas e universidades e programas de geração e difusão de novos conhecimentos;

\subsection{PERSPECTIVAS PARA TRABALHO FUTURO}

Este trabalho permite sugerir, como complemento da análise efetuada, as seguintes linhas de investigação para trabalhos futuros:

$>$ Identificar as dificuldades enfrentadas pelas equipes de projeto no processo de documentação necessário para obter as certificações (LEED e Processo AQUA).

$>$ Propor diretrizes para organização do processo de projeto de edifícios sustentáveis, e das equipes de projeto.

> Determinar a relação existente entre a obtenção das certificações ambientais para edifícios e a melhoria da imagem da empresa que instala suas operações em um edifício certificado. 
- A-

Agenda 21 para Construção Sustentável em Países em Desenvolvimento. THE INTERNATIONAL COUNCIL FOR RESEARCH AND INNOVATION IN BUILDING AND CONSTRUCTION AND UNITED NATIONS ENVIRONMENT PROGRAM. África do Sul, 2002, 82 p.

BENITE, A. Green Building: o desafio da compra de materiais sustentáveis. 2010. Disponivel em: < http://www.cte.com.br/site/artigos ler.php?id artigo=2704 >. Acesso em: 10 fev. de 2012.

BRUNDTLAND, G. Our common future: The world commission on environment and development. Oxford: Oxford University Press, 1987.

$-\mathrm{C}-$

CAPUZZI, A. Strategic planning for LEED certification. 2010. 51 f. Dissertação (Mestrado) -Massachusetts Institute of Technology, Sloan School of Management and the Department of Engineering Systems, Massachusetts, 2010.

CARDOSO, F. Certificação de empreendimento comercial de elevado desempenho ambiental 2002. PCC USP/CSTB, São Paulo, 2003.

CIB e UNEP-ITEC. Agenda 21 for sustainable construction. Petrória. África do Sul: CSIR Building Construction Technology, 2002.

COOPER, G. M. Leadership in Energy and Environmental Design (LEED) and Higher Education: Planning for Documentation and Communication at the University of South Carolina Living and Learning Center. Master of Earth and Environmental Resources Management Thesis, University of South Carolina, 2002, 113 pages. Disponivel em: < 
http://www.me.sc.edu/Research/lss/Papers/GinaCooperThesis.pdf >. Acesso em: Outubre de 2011.

CORBETT , C. J.; LUCA , A. M.; PAN, J. Global Perspectives on Global Standards: a 15Economy Survey of ISO 9000 and ISO 14000. ISO Management Systems, JaneiroFevereiro de 2003.

CRYER, B., FELDER, J., MATTHEWS, R., PETTIGREW, M., OKRENT, B. Evaluating the diffusion of green building practices. UCLA Anderson School of Management, Califórnia, 2005/2006.82 p.

- D -

DARNALL, N.; GALLAGHER, D. R. e ANDREWS, R. N. L. ISO 14001: Greening Management Systems. In J. Sarkis - Greener Manufacturing and Operations: From Design to Delivery and Back (Cap. 12), Greenleaf Publishing, Sheffield, 2001.

D’ÂNGELO, F.; AMATO NETO, J. Motivações e contradições na implementação e certificação de um sistema da qualidade. 1997.

DA SILVA, L. A review of LEED credits in Canadian building projects to optimize benefits and lower costs. 2008. 220 pages. Master of Science - Department of civil engineering, University of Calgary, Alberta, 2008.

DAVIES, R. Green Value, Green Building, growing assets, Report 2005. Em <http://www.metrovancouver.org/about/publications/Publications/greenvaluecasestudies1. pdf $>$. Acesso em: Outubro de 2011.

DEGANI, C. Modelo de gerenciamento da sustentabilidade de facilidades construídas. 2009. 214 f.Tese (Doutorado), EPUSP, São Paulo, 2009.

DIAMOND, C. P. Environmental Management System Demonstration Project: Final Report. NSF International, Ann Arbor, Michigan, 1996. Disponível em http://www.p2pays.org/ref/01/00326.pdf. Acesso em: Fevereiro 2012.

DICIONÁRIO MINI AURÉLIO DA LÍNGUA PORTUGUESA . 896 p.7. ed., Curitiba: Ed. Positivo, 2008. 
EDWARDS, B. How do green buildings pay? In: EDWARDS, B. Green Buildings Pay. London: E\& FN Spon, 1998. p. 2-17.

$-F$ -

FCAV - FUNDAÇÃO CARLOS ALBERTO VANZOLINI. Referencial técnico de certificação: Edifícios habitacionais - Processo AQUA. São Paulo: Fundação Vanzolini. Fevereiro 2010 - Versão 1.

FCAV - FUNDAÇÃO CARLOS ALBERTO VANZOLINI. Info sheet. Página institucional. Disponível em: <http://www.vanzolini.org.br/hotsite-104.asp?cod_site=104>. Acesso em: 11 de Abril de 2012.

FIGUEIREDO, F.G.; SILVA, V.G. Projeto integrado para melhoria do desempenho ambiental de edificações. Revista Téchne, edição 163. São Paulo, Outubro, 2010.

FLORIM, L.; QUELHAS, O. Contribuição para a construção sustentável: características de um projeto habitacional ecoeficiente. Revista Produção, Florianópolis, jun. 2005. Disponível em: <www.producaonline.org.br>. Acesso em: 11 março 2012.

FOSSATI, M. Metodologia para avaliação da sustentabilidade de projetos de edifícios: o caso de escritórios em Florianópolis. 2008. 342 p.Tese (Doutorado)- Programa de PósGraduação em Engenharia Civil, Universidade Federal de Santa Catarina., Florianópolis, SC, 2008.

FOSTER, S.; SAMPSON E; DUNN, S. C. The impact of customer contact on environmental initiatives for service firms. International Journal of Operations \& Production Management, v. 20, n. 2, p. 187-203, 2000.

$-\mathrm{G}-$

GALAZ, YAMAZAKI, URQUIZA. Los dólares y el sentido del acondicionamento ecológico. Revista Deloitte, 2009.

GARRIDO, L. Análisis de proyectos de arquitectura sostenible. España: Mc Graw-Hill/ Interamericana de España, S.A.U., España, 2009. 
GBc Brasil 2012 - GREEN BUILDING COUNCIL BRASIL. Info sheet. Página institucional. Disponível em: < http://www.gbcbrasil.org.br >. Acesso em: 11 de augusto de 2012.

GIL, A. Como elaborar projetos de pesquisa. 4 ed., São Paulo: Atlas S.A., 2007.

$-\mathrm{H}-$

HERNANDES, T. LEED-NC como sistema de avaliação da sustentabilidade: uma perspectiva nacional?. 2006. 134 f. Dissertação (Mestrado), Faculdade de Arquitetura e Urbanismo-Universidade de São Paulo, São Paulo, 2006.

HILGENBERG, F. Sistemas de certificação ambiental para edifícios estudo de caso: AQUA.2010. 153 f. Dissertação (Mestrado), Programa de Pós- Graduação em construção civil -Universidade Federal do Paraná, Curitiva, PR, 2010.

HONDA, W.; ROCHA LIMA, J. Sustentabilidade na operação de edifícios de escritórios. In: 10 Conferencia Internacional da LARES, São Paulo, setembro 15-17, 2010.

$-1-$

ISERN, J. Visión estratégica de la sostenibilidad: aplicación al sector hospitalario. Grupo JG ingenieros consultores. Sesión sobre el proyecto hospitalario: Nuevas prioridades e herramientas, 2010.

$-\mathrm{J}-$

JOHNSON, B. Barriers to certification for LEED registered projects. 2005. 90 pages. Master of Science, Department of Construction Management- Colorado State University Fort Collins,Colorado ,2005.

$-\mathrm{K}$ -

KATS, G. The cost financial benefits of green buildings. A Report to California's Sustainable Building Task Force, 2003.

KADZIS, R. Sustainability Perceptions and Trends: A CoreNet Global Research Bulletin, CoreNet Global, January 2008, p. 8. 
KIBERT, C. Sustainable construction: green building design and delivery. 2nd Ed. New Jersey: John Wiley \& Sons, Inc., Hoboken. Gainesville, Florida, 2007.

KUA, H. W.; LEE, S. E. Demonstration intelligent building - a methodology for the promotion of total sustainability in the built environment. Building and Environment. n. 37, p.231-240, 2002.

- L -

LANGDON, D. Costing of green revisited: reexamining the feasibility and cost impact of sustainable design in the light of increased market adoption. 2007. 25 p. Disponível em: $<$ http://www.davislangdon.com/upload/images/publications/USA/The\%20Cost\%20of\%20 Green\%20Revisited.pdf>. Acesso em: 11 nov. 2011.

LAM, C. Empreendimentos eco-sustentáveis: aplicação de parâmetros de ecosustentabilidade em edifícios comerciais no mercado imobiliário de São Paulo. 2004. 91 f. Monógrafia - Programa de Educação Continuada em Engenharia da Escola Politécnica da Universidade de São Paulo, São Paulo, 2004.

LARSSON, N.An overview of green building rating and labelling systems. iisbe: 2004. Disponivel em: <http://greenbuilding.ca/lisbe/start/iisbe.htm>. Acesso em: 2009.

LUCUIK, M.; TRUSTY, W.; LARSSON, N.; CHARETTE, R. Report: A business case for green guildings in Canada. Morrison Hershfield, Canada, 2005.

$-M-$

MAPP, C.; NOBE, M.E.; DUNBAR, B. The cost of LEED: An analysis of the construction costs of LEED and Non-LEED Banks. JOSRE, vol.3, n.1, 2011.

MARCONI, M.; LAKATOS, E. Ténicas de pesquisa: planejamento e execução de pesquisas, amostragens e técnicas de pesquisa, elaboração, analise e interpretação de dados. São Paulo: Altas, 1982.

MENEGAT, R. Desenvolvimento sustentável e gestão ambiental nas cidades. Porto Alegre: Editora da UFRGS, 2004. 
MiLler, N.; SPIVEY, J.; FlORANCE, A. Does Green Pay off?. The journal of sustainable Real Estate, 2008.

$-\mathbf{N}-$

NATIONAL RESOURCES CANADA- NRC/CAMMET ENERGY TECHNOLOGY CENTRE (Ed.). Green Building Challenge'98: na international conference on the Performance Assessment of Building. Proceedings. NRC/CANMET, Vancouver,1998.

NEGREIROS, I. Diretrizes para projetos de loteamentos urbanos considerando os métodos de avaliação ambiental. 2009. 161 f.Dissertação (Mestrado) - EP USP,São Paulo, 2009.

$-P$ -

PARDINI, A. Contribuição ao entendimento da aplicação da certificação LEED e do conceito de custos no ciclo de vida em empreendimentos mais sustentaveis no Brasil. 2009. 227 f. Dissertação (Mestrado)- Universidade Estadual de Campinas, Faculdade de Engenharia Civil, Arquitetura e Urbanismo, Campinas, SP, 2009.

PICCOLI, R.; KERN, A.; GONZALEZ, M.; HIROTA, E. A certificação de desempenho ambiental de prédios: exigências usuais e novas atividades na gestão da construção. In: Ambiente construído. Porto Alegre,v10, n.3, p. 69-79, jul./set.2010.

PICCOLI, R. Análise das alterações no processo de construção decorrente da aplicação de sistema de certificação ambiental de edificações. 2009. 103 f. Dissertação (Mestrado), Programa de Pós-Graduação em Engenharia Civil, UNISINOS, São Leopoldo, 2009.

PIRES, F.; CARVALHO JUNIOR, L. A estratégia ambiental como elemento competitivo de empresas da construção civil atuantes em Florianópolis. In: II ENCONTRO DE ECONOMIA CATARINENSE, 2008, Chapecó, Anais... Chapecó SC: 24, 25 e 26 de Abril de 2008 .

PEARCE, A.; DUBOSE, J.; BOSCH, S.; CARPENTER, A.Greening Georgia Facilities: $\mathrm{Na}$ analysis of LEED requirement impacts. Georgia Tech Research Institute's - Sustainable Facilities \& Infrastructure Program, Georgia, 2005. 
REIS, A.; LAY, M. Avaliação da qualidade de projetos: uma abordagem perceptiva e cognitiva. Ambiente Construído, Porto Alegre, v.6, n.3, jul./set. 2002.

RIES, R.; BILEC. The economic benefits of green buildings: a comprehensive case study. Engineering economist, v. 51, n. 3, p. 259-295, jul./set.2006.

RODRIGO, A.; CARDOSO, F. Certificação ambiental de edificios pelo processo AQUA e alterações no processo de gestão do empreendimento e no edifício. In: XIII ENCONTRO NACIONAL DE TECNOLOGIA DO AMBIENTE CONSTRUIDO, 2010, Canela. Anais... Canela RS: (s.n.),2010.

- S -

SALANT, P.; DILLMAN, D. How to conduct your own survey. New York: Wiley, 1994.

SERRADOR, M. Sustentabilidade em arquitetura: referencias para projeto. 2008. 268 F.Dissertação (Mestrado), EESC- USP, São Carlos, 2008.

SCHENDLER, A.; UDALL, R. LEED is Broken: Let's fix it. Aspen, United States, 2005.

SILVA, V.G. Metodologias de avaliação de desempenho ambiental de edifícios: estado atual e discussão metodológica. Projeto Tecnologias para construção habitacional mais sustentável. Projeto Finep .2386/04-2007. UNICAMP- Universidade de Campinas -. SP, BR.

SILVA, V.; DA; AGOPYAN, V. Avaliação de edifícios no Brasil: Saltando de avaliação ambiental para avaliação de sustentabilidade. São Paulo: Escola politécnica da USP Departamento de Engenharia de Construção Civil, 2004. 12 p. Boletim Técnico BT/PCC/376.

SILVA, V.G. Avaliação da sustentabilidade de edifícios de escritórios brasileiros: diretrizes e base metodológica.2003. 210 p. Tese (Doutorado) - Departamento de Engenharia Civil. Escola Politécnica da Universidade de São Paulo, 2003. 
SMITH, P. Green buildings: the long-term payoff. In: EDWARDS, B. Green Buildings Pay. London: E\& FN Spon, 1998.p. 126-132.

SOUSA, H. Contributos para a elaboração de um sistema de avaliação e certificação de áreas residenciais. 2007. 199 f. Dissertação (Mestrado) - Faculdade de Ciencias e Tecnologia, Universidade de Lisboa, Lisboa, 2007.

SUSTENTARE. Implementação de um sistema de avaliação de desempenho ambiental da construção - LEED. Portugal, Lisboa, 2009.

SCHAUFELBERGER, J.; CLOUD, J. LEED certification: a constructor's perspective. In: 2009 Construction Research Congress, ASCE, Seatle, USA, 2009.

SYPHERS, G.; BAUM, M.; BOUTON, D.; SULLENS, W. Managing the Cost of Green Buildings: K-12 Public Schools, Research Laboratories, Public Libraries, Multi- Family Affordable Housing, 2003. Disponível em: 〈http://www.ciwmb.ca.gov/greenbuilding/Design/ManagingCost.pdf $>$. Acesso em: $11 \mathrm{de}$ outubro de 2010.

$-\mathrm{T}-$

SEGet. Gestão Sócio- Ambiental: O papel do Governo diante do paradoxo economia x ecologia. In: II SEGet- Simposio de excelência em gestão e tecnologia, 2005.

Avaliação ambiental. Revista Téchne. Editora Pini, São Paulo, edição 133,Abril, 2008 .

Carimbo verde. Revista Téchne. Editora Pini, São Paulo, edição 155, ano 18, Fevereiro, 2010, p.37.

TZSCHENTKR, N; KIRK, D; LYNCH, P. A. Reasons for going green in serviced accommodation establishments. International Journal of Contemporary Hospitality Management, v. 16, n. 2, p. 116-124, 2004.

THE EUROPEAN COMMISION; CONSELHO DE ARQUITETOS EUROPEUS (ACE); ENERGY RESEARCH GROUP (ERG); SAFA; SOFTECH; ORDEM DOS ARQUITETOS. A Green Vitruvius: princípios e praticas de projeto para uma arquitetura sustentavel. Ordem dos Arquitetos. Portugal, 2001. 
TORCELLINI, P.A. et al. Lessons learned from the field evaluation of six highperformance buildings. In: ACEEE Summer Study on Energy Efficiency of Buildings, American Council for an Energy-Efficient Economy. Anais... Washington DC, 2004. Pp. 3-325-3-337.

TURNER CONSTRUCTION. Market Barometer 2005: Survey of green Building Plus green Building in K-12 and higher education. 2005.

TURNER GREEN . Market Barometer 2010: Survey of green Building market barometer. 2010 .

$-U-$

USGBC - UNITED STATES GREEN BUILDING COUNCIL. Info sheet. Página institucional. Disponível em: < http://www.usgbc.org >. Acesso em: 11 de outubro de 2010.

$-\mathrm{V}-$

VASCONCELlOS, L.; GUEDES, L. E- Surveys: Vantagens e limitações dos questionários eletrônicos via internet no contexto da pesquisa cientifica. In: Anais do X SEMEAD, Seminario de Administração, São Paulo., v.1, p. 1-15, 2007.

VILLELA, D. A sustentabilidade na formação atual do arquiteto e urbanista. 2007. 181 f. Dissertação (Mestrado), Pós-Graduação da Escola de Arquitetura, Universidade Federal de Minas Gerais, Belo Horizonte, 2007.

VOSGUERITCHIAN, A. A abordagem dos sistemas de avaliação de sustentabilidade da arquitetura nos questios ambientais de energia, materiais e água, e suas associações às inovações tecnológicas. 2006. 247 f. Dissertação (Mestrado) - Área de concentração: Tecnologia da Arquitetura, Faculdade de Arquitetura e Urbanismo da USP, São Paulo, 2006. 
WOOD, J. The green house: Barriers and breakthroughs in residential green building.2007. 123 f. Dissertação (Mestrado) - Area de concentração: Urban and Environmental Policy and Planning, Tufts University, 2007.

$-\mathbf{Z}-$

ZIMMERMANN, A; AHO, I. BORDASS, B.; GEISSLER, S.; JAANISTE, R.Proposed framework for environmental assessment of existing buildings. In: Sustainable Building 2002. Proceedings. iiSBE/CIB/Biggforsk: Oslo, Norway. 23-25 September 2002.(Published in CDRom). 


\section{ANEXO A}

\section{CARTA}
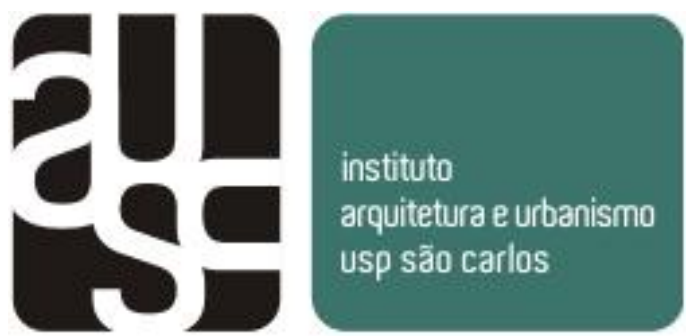

São Paulo, 6 de Março de 2012

Prezado (a) colaborador (a):

A freqüência no curso de Mestrado no Programa de pós-graduação em arquitetura e urbanismo USP/IAU exige-me a elaboração de uma dissertação escrita. Por este motivo decidi estudar as motivações, benefícios e dificuldades associadas à adoção de sistemas de certificação ambiental de edifícios nas empresas brasileiras.

Para a elaboração da referida dissertação, a sua experiência e opinião é muito importante. Por isso, agradeço a colaboração que possa prestar através do preenchimento do questionário. Esta operação demorará menos de 15 minutos e poderá ser efetuada eletronicamente, devendo acessar ao link do questionário que esta no corpo do e-mail para depois de preencher o questionário clicar no botão (submit).

Aproveito esta oportunidade para referir que todas as respostas serão tratadas confidencialmente e que no texto da dissertação não serão divulgadas qualquer referencia à designação das empresas contatadas.

Agradecendo, desde já, a colaboração prestada, antecipadamente e colocamo-nos à disposição para demais esclarecimentos, caso seja de seu interesse posso enviar uma copia do trabalho final em PDF.

Com os melhores cumprimentos,

\section{Ana Dorys Muñoz Barros}

Mestranda em Arquitetura, Urbanismo e Tecnologia - USP/IAU

anamunoz@usp.br

\section{Marcio Fabrício Minto}

Orientador-Professor Assoc. do Instituto de Arquitetura e Urbanismo da USP

marcio@sc.usp.br

Telf.- (016) 3373-9279 


\section{QUESTIONÁRIO PARA O EMPREENDEDOR LEED}
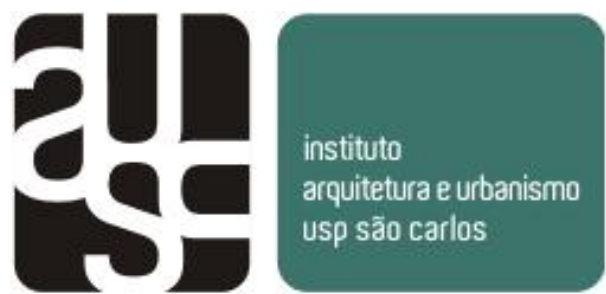

IAU-USP /Área de Tecnologia do Instituto de Arquitetura e Urbanismo da Universidade de São Paulo

\section{QUESTIONÁRIO-EMPREENDEDOR LEED}

Este questionário tem objetivos estritamente acadêmicos e apóia a realização de uma tese de mestrado. Agradecemos sua colaboração no preenchimento de cada um dos campos de resposta deste questionário.

\section{1:Dados gerais}

Nome Telefone

Empresa

1. Você é o proprietário ou investidor do empreendimento ? $\operatorname{Sim}$ Não

2. Em quantos empreendimentos certificados, você já participou?

3. Empreendimento e localização

4. Qual é o nível de certificação do empreendimento?

\begin{tabular}{|l|l|l|l|}
\hline _Platina & _Ouro & _Prata & _Certificado \\
\hline
\end{tabular}

\section{2: Motivações}

5. Indique o motivo mais importante para a obtenção da certificação?

Gestão ambiental Tomar como prioridade a construção sustentável Validar a realização através da análise de terceiros

Vantagem competitiva

Exigência do governo Incentivos do governo local, estadual, federal Oportunidades de lucro A empresa emprega a sustentabilidade na estratégia de seus negócios Exigências dos clientes e outras partes interessadas Redução dos custos de operação Melhoria da imagem Acesso a novos mercados 
Buscar estabelecer um padrão ou dar o exemplo

Melhorar a qualidade de vida de seus ocupantes

Melhorar o resultado final (melhor produto/edifício)

6. Entre as opções abaixo, indique cada quesito que, em sua opinião, são os principais motivos para a obtenção da certificação. Indique, qual o grau de importância de cada um desses fatores 1: Sem importância; 2: Pouco importante; 3: Regularmente importante; 4: Importante; 5: Muito importante.

Gestão ambiental

Tomar como prioridade a construção sustentável

Validar a realização através da análise de terceiros

Vantagem competitiva

Exigência do governo

Incentivos do governo local, estadual, federal

Oportunidades de lucro

A empresa emprega a sustentabilidade na estratégia de seus negócios

Exigências dos clientes e outras partes interessadas

Redução dos custos de operação

Melhoria da imagem

Acesso a novos mercados

Buscar estabelecer um padrão ou dar o exemplo

Melhorar a qualidade de vida de seus ocupantes

Melhorar o resultado final (melhor produto/edifício)

Outros (comentar)

\section{3: Benefícios da implementação do LEED}

7. Indique o beneficio mais importante para a obtenção da certificação?

Redução dos custos de investimento, operação e manutenção

Benefícios econômicos

Redução de danos, preservação e recuperação do meio ambiente

Tornam os empreendimentos mais atraentes o que garante um maior valor agregado

Imagem, diferenciação e valorização do produto (empreendimento)

Redução dos riscos

Mais produtividade, conforto e saúde do usuário

Novas oportunidades de negócios

Publicidade (ganhos em mídia gratuita)

Melhora a qualidade do processo de construção e de seus produtos (empreendimento)

Validar a realização através da analise de terceiros

Aumenta as vendas no varejo

Benefícios em custo de infra-estrutrua

Criação de emprego 
8. Quais são os benefícios que você recebe ou pretende receber, para sua construção sustentável? Indique, qual o grau de importância de cada um desses fatores 1: Sem importância; 2: Pouco importante; 3: Regularmente importante; 4: Importante; 5: Muito importante.

Redução dos custos de investimento, operação e manutenção

Benefícios econômicos

Redução de danos, preservação e recuperação do meio ambiente

Tornam os empreendimentos mais atraentes o que garante um maior valor agregado Imagem, diferenciação e valorização do produto (empreendimento)

Redução dos riscos

Mais produtividade, conforto e saúde do usuário

Novas oportunidades de negócios

Publicidade (ganhos em mídia gratuita)

Melhora a qualidade do processo de construção e de seus produtos (empreendimento)

Validar a realização através da analise de terceiros

Aumenta as vendas no varejo

Benefícios em custo de infra-estrutrua

Criação de emprego

Outros (comentar)

\section{4: Limitações da certificação LEED}

9. Indique a dificuldade mais difícil para a obtenção da certificação?

Documentação LEED / Burocracia excessiva

Obter a documentação LEED necessária dos (fornecedores, projetistas, construtora, consultores)

Comunicação/desentendimento com o USGBC

Falta de integração no processo de projeto

Pouca integração e falta de cooperação entre os agentes envolvidos (cliente, arquiteto,

projetistas, construtora, consultores etc.)

Falta de cooperação entre equipes (agentes envolvidos)

Falta de fornecedores especializados para os insumos (materiais e tecnologias

sustentáveis) que o empreendimento demanda ou demandou

Mudanças do escopo do projeto

Rotatividade da equipe de projeto

Equipe ineficaz

Falta de conhecimento dos integrantes da equipe

Falta de experiência dos integrantes da equipe do projeto (formação insuficiente) acerca do LEED e empreendimentos verdes

Falta pessoal treinado-operarios (mão de obra qualificada)

Taxa ou custo direto da certificação

Custo da documentação 
Custo das tecnologias sustentáveis empreendidas no projeto e da mão de obra especializada

Alto custo empregado para o projeto-execução do empreendimento verde

Dificuldade em recuperar os custos iniciais

Complexidade das simulações energéticas e dos ensaios com materiais

Clima e localização regional do empreendimento

Falta de adequação das normas internacionais às regionais

Resistência dos projetistas e da construtora em implantar efetivamente algumas exigências (das categorias) solicitadas pela certificação LEED

Falta de comprometimento e empenho dos agentes

Questões relacionadas aos confortos térmicos, acústico e luminico

Tempo necessário para implementar práticas de sustentabilidade com base nos

requisitos do LEED

Dificuldade em satisfazer os pré-requisitos do LEED

Dificuldade em qualificar para a certificação LEED desejada

Convencer as partes interessadas a buy-in para o LEED

10. Quais as principais dificuldades encontradas ao longo do processo de implementação da certificação LEED? Indique, qual o grau de dificuldade de cada um desses fatores 1: Sem dificuldade; 2: Pouco difícil; 3: Regularmente difícil; 4: Difícil; 5: Muito difícil.

Documentação LEED / Burocracia excessiva

Obter a documentação LEED necessária dos (fornecedores, projetistas, construtora, consultores)

Comunicação/desentendimento com o USGBC

Falta de integração no processo de projeto

Pouca integração e falta de cooperação entre os agentes envolvidos (cliente, arquiteto, projetistas, construtora, consultores etc.)

Falta de cooperação entre equipes (agentes envolvidos)

Falta de fornecedores especializados para os insumos (materiais e tecnologias

sustentáveis) que o empreendimento demanda ou demandou

Mudanças do escopo do projeto

Rotatividade da equipe de projeto

Equipe ineficaz

Falta de conhecimento dos integrantes da equipe

Falta de experiência dos integrantes da equipe do projeto (formação insuficiente) acerca do LEED e empreendimentos verdes

Falta pessoal treinado-operarios (mão de obra qualificada)

Taxa ou custo direto da certificação

Custo da documentação

Custo das tecnologias sustentáveis empreendidas no projeto e da mão de obra especializada 
Alto custo empregado para o projeto-execução do empreendimento verde

Dificuldade em recuperar os custos iniciais

Complexidade das simulações energéticas e dos ensaios com materiais

Clima e localização regional do empreendimento

Falta de adequação das normas internacionais às regionais

Resistência dos projetistas e da construtora em implantar efetivamente algumas exigências

(das categorias) solicitadas pela certificação LEED

Falta de comprometimento e empenho dos agentes

Questões relacionadas aos confortos térmicos, acústico e luminico

Tempo necessário para implementar práticas de sustentabilidade com base nos requisitos do LEED

Dificuldade em satisfazer os pré-requisitos do LEED

Dificuldade em qualificar para a certificação LEED desejada

Convencer as partes interessadas a buy-in para o LEED

Outras (comentar)

11. Você pode comentar livremente as dificuldades mencionadas

\section{5:Processo de certificação LEED}

12. Quem ficou responsável por orientar as decisões, fornecer informações sobre o processo de certificação, elaborar e organizar a documentação exigida pelo USGBC?

\begin{tabular}{|l|l|l|l|}
\hline ( )Empresa fiscalizadora & $($ )Arquiteto & $($ ) Construtora & $($ )Engenheiro \\
\hline $\begin{array}{l}\text { ( )Profissional } \\
\text { credenciado LEED }\end{array}$ & $($ )Empreendedor & $($ Gerente de comissionamento \\
\hline ( ) Incorporador & Outros (especificar) & \\
\hline
\end{tabular}

13.Qual a principal dificuldade com os projetistas, empresa fiscalizadora, proprietário,empreendedor,incorporador, fornecedores, construtora?

14. Quanto foi o custo adicional (\% ou $R \$$ ) associado à implementação da certificação LEED no:

\begin{tabular}{|l|l|l|l|}
\hline$($ )Projeto & $($ ) Consultoria & $($ )Execução & $($ Certificação \\
\hline$($ )Consultores & $($ ) Materiais & $($ Ensaios & $($ Operacionais \\
\hline \multicolumn{2}{|l}{ ( Outros (especificar) }
\end{tabular}

15. Quanto foi o custo adicional em relação a uma edificação convencional (custos do projeto, construção e operação)?\% ou $R$ \$

16. Em que medida a certificação LEED afetou o processo de projeto, execução e produto final (edifício) ? 1:Muito pior, 2:Um pouco pior, 3:Similar, 4:Um pouco melhor, 5:Muito melhor Projeto

Execução

Produto final (edifício) 
17. Indique, O grau de dificuldade em atingir as categorias exigidas pela certificação LEED 1:Muito fácil, 2:Fácil, 3:Indiferente, 4:Difícil, 5:Muito difícil

Terrenos sustentaveis

Uso racional da água

Energia e atmosfera

Materiais e recursos

Qualidade do ambiente interno

Projeto e inovação

\section{6: Evolução da certificação}

18. Na sua opinião, como poderia ser melhorado o processo de certificação? Menos burocracia / interface on-line Simplificar a documentação e certificação Integrar melhor as fases de projeto e de construção Melhor atendimento ao cliente e feedback Mais marketing para o mercado imobiliário Outros (comentar)

Sugestoes/comentarios

Muito obrigado pela sua colaboração. 


\section{QUESTIONÁRIO PARA O EMPREENDEDOR DO PROCESSO AQUA}

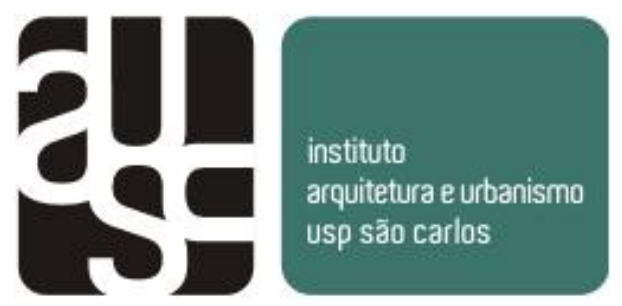

IAU-USP /Área de Tecnologia do Instituto de Arquitetura e Urbanismo da Universidade de São Paulo

\section{QUESTIONÁRIO-EMPREENDEDOR AQUA}

Este questionário tem objetivos estritamente acadêmicos e apóia a realização de uma tese de mestrado. Agradecemos sua colaboração no preenchimento de cada um dos campos de resposta deste questionário.

\section{1:Dados gerais}

Nome Telefone

Empresa

1. Você é o proprietário ou empreendedor do empreendimento ? Sim Não

2. Empreendimento e localização

\section{2: Motivações}

3. Indique o motivo mais importante para a obtenção da certificação?

Gestão ambiental

Tomar como prioridade a construção sustentável

Validar a realização através da análise de terceiros

Vantagem competitiva

Exigência do governo

Incentivos do governo local, estadual, federal

Oportunidades de lucro

A empresa emprega a sustentabilidade na estratégia de seus negócios

Exigências dos clientes e outras partes interessadas

Redução dos custos de operação

Melhoria da imagem

Acesso a novos mercados

Buscar estabelecer um padrão ou dar o exemplo

Melhorar a qualidade de vida de seus ocupantes

Melhorar o resultado final (melhor produto/edifício)

4. Entre as opções abaixo, indique cada quesito que, em sua opinião, são os principais motivos para a obtenção da certificação. Indique, qual o grau de importância de cada um desses fatores 
1: Sem importância; 2: Pouco importante; 3: Regularmente importante; 4: Importante; 5: Muito importante.

Gestão ambiental

Tomar como prioridade a construção sustentável

Validar a realização através da análise de terceiros

Vantagem competitiva

Exigência do governo

Incentivos do governo local, estadual, federal

Oportunidades de lucro

A empresa emprega a sustentabilidade na estratégia de seus negócios

Exigências dos clientes e outras partes interessadas

Redução dos custos de operação

Melhoria da imagem

Acesso a novos mercados

Buscar estabelecer um padrão ou dar o exemplo

Melhorar a qualidade de vida de seus ocupantes

Melhorar o resultado final (melhor produto/edifício)

Outros (comentar)

\section{3: Benefícios da implementação do Processo AQUA}

5. Indique o beneficio mais importante para a obtenção da certificação?

Redução dos custos de investimento, operação e manutenção

Benefícios econômicos

Redução de danos, preservação e recuperação do meio ambiente

Tornam os empreendimentos mais atraentes o que garante um maior valor agregado

Imagem, diferenciação e valorização do produto (empreendimento)

Redução dos riscos

Mais produtividade, conforto e saúde do usuário

Novas oportunidades de negócios

Publicidade (ganhos em mídia gratuita)

Melhora a qualidade do processo de construção e de seus produtos (empreendimento)

Validar a realização através da analise de terceiros

Aumenta as vendas no varejo

Benefícios em custo de infra-estrutrua

Criação de emprego

6. Quais são os benefícios que você recebe ou pretende receber da implementação do Processo AQUA para este empreendimento? Indique, qual o grau de importância de cada um desses fatores 1: Sem importância; 2: Pouco importante; 3: Regularmente importante; 4: Importante; 5: Muito importante.

Redução dos custos de investimento, operação e manutenção

Benefícios econômicos 
Redução de danos, preservação e recuperação do meio ambiente

Tornam os empreendimentos mais atraentes o que garante um maior valor agregado Imagem, diferenciação e valorização do produto (empreendimento)

Redução dos riscos

Mais produtividade, conforto e saúde do usuário

Novas oportunidades de negócios

Publicidade (ganhos em mídia gratuita)

Melhora a qualidade do processo de construção e de seus produtos (empreendimento)

Validar a realização através da analise de terceiros

Aumenta as vendas no varejo

Benefícios em custo de infra-estrutrua

Criação de emprego

Outros (comentar)

\section{4: Limitações do Processo AQUA}

7. Indique a dificuldade mais difícil para a obtenção da certificação?

Documentação / Burocracia excessiva

Obter a documentação necessária dos (fornecedores, projetistas, construtora, consultores)

Comunicação/desentendimento com a FCAV

Falta de integração no processo de projeto

Pouca integração e falta de cooperação entre os agentes envolvidos (cliente, arquiteto, projetistas, construtora, consultores etc.)

Falta de cooperação entre equipes (agentes envolvidos)

Falta de fornecedores especializados para os insumos (materiais e tecnologias

sustentáveis) que o empreendimento demanda ou demandou

Mudanças do escopo do projeto

Rotatividade da equipe de projeto

Equipe ineficaz

Falta de conhecimento dos integrantes da equipe

Falta de experiência dos integrantes da equipe do projeto (formação insuficiente) acerca do

Processo AQUA e empreendimentos verdes

Falta pessoal treinado-operarios (mão de obra qualificada)

Taxa ou custo direto da certificação

Custo da documentação

Custo das tecnologias sustentáveis empreendidas no projeto e da mão de obra especializada

Alto custo empregado para o projeto-execução do empreendimento verde

Dificuldade em recuperar os custos iniciais

Complexidade das simulações energéticas e dos ensaios com materiais

Clima e localização regional do empreendimento 
Falta de adequação das normas internacionais às regionais

Resistência dos projetistas e da construtora em implantar efetivamente algumas exigências (das categorias) solicitadas pelo Processo AQUA

Falta de comprometimento e empenho dos agentes

Questões relacionadas aos confortos térmicos, acústico e luminico

_ Tempo necessário para implementar práticas de sustentabilidade com base nos requisitos do Processo AQUA

Dificuldade em satisfazer as categorias do Processo AQUA

Dificuldade em qualificar para nivel desejado

Convencer as partes interessadas a buy-in para o Processo AQUA

8. Quais as principais dificuldades encontradas ao longo do processo de implementação do Processo AQUA? Indique, qual o grau de dificuldade de cada um desses fatores 1: Sem dificuldade; 2: Pouco difícil; 3: Regularmente difícil; 4: Difícil; 5: Muito difícil.

Documentação / Burocracia excessiva

Obter a documentação necessária dos (fornecedores, projetistas, construtora, consultores)

Comunicação/desentendimento com a FCAV

Falta de integração no processo de projeto

Pouca integração e falta de cooperação entre os agentes envolvidos (cliente, arquiteto, projetistas, construtora, consultores etc.)

Falta de cooperação entre equipes (agentes envolvidos)

Falta de fornecedores especializados para os insumos (materiais e tecnologias

sustentáveis) que o empreendimento demanda ou demandou

Mudanças do escopo do projeto

Rotatividade da equipe de projeto

Equipe ineficaz

Falta de conhecimento dos integrantes da equipe

Falta de experiência dos integrantes da equipe do projeto (formação insuficiente) acerca do Processo AQUA e empreendimentos verdes

_Falta pessoal treinado-operarios (mão de obra qualificada)

Taxa ou custo direto da certificação

_ Custo da documentação

_ Custo das tecnologias sustentáveis empreendidas no projeto e da mão de obra especializada

Alto custo empregado para o projeto-execução do empreendimento verde

Dificuldade em recuperar os custos iniciais

Complexidade das simulações energéticas e dos ensaios com materiais

Clima e localização regional do empreendimento

Falta de adequação das normas internacionais às regionais 
Resistência dos projetistas e da construtora em implantar efetivamente algumas exigências (das categorias) solicitadas pelo Processo AQUA

Falta de comprometimento e empenho dos agentes

Questões relacionadas aos confortos térmicos, acústico e luminico

Tempo necessário para implementar práticas de sustentabilidade com base nos requisitos do Processo AQUA

Dificuldade em satisfazer as categorias do Processo AQUA

Dificuldade em qualificar para nivel desejado

Convencer as partes interessadas a buy-in para o Processo AQUA

Outras (comentar)

9. Você pode comentar livremente as dificuldades mencionadas

\section{5: Processo de certificação}

10. De quem surgiu a idéia de certificar com o Processo AQUA o empreendimento?

\begin{tabular}{|l|l|l|}
\hline$($ )Incorporador & $($ )Arquiteto & $($ )Proprietário \\
\hline$($ )Empreendedor & $($ )Consultor \\
\hline Outro (especificar)
\end{tabular}

11. Quanto foi o custo adicional (\% ou $R \$$ ) associado à implementação do Processo AQUA no:

\begin{tabular}{|c|c|c|c|c|}
\hline & )Projeto & ( )Consultoria & ( ) Execução & ( )Certificação \\
\hline ( & )Consultores & ( )Materiais & ( ) Ensaios & ( )Operacionais \\
\hline
\end{tabular}

12. Quanto foi o custo adicional em relação a uma edificação convencional (custos do projeto, construção e operação)?\% ou $\mathrm{R} \$$

13. Quais foram as dificuldades enfrentadas por você ao implementar o SGE e avaliar o QAE?

14. Quais são os pontos críticos e de sucesso para a gestão do processo de projeto?

15.Qual a principal dificuldade com os projetistas, empresa fiscalizadora, proprietário,empreendedor,incorporador, fornecedores, construtora?

16.Quem ficou responsável do fluxo de informações (entre os projetistas, especialistas e empreendedor) e de estruturar os documentos exigidos pelo processo de certificação AQUA?

\begin{tabular}{|l|l|l|l|}
\hline ( )Empresa fiscalizadora & ( )Arquiteto & $($ )Construtora & $($ )Engenheiro \\
\hline
\end{tabular}




\begin{tabular}{|l|l|l|}
\hline ( ) Incorporador & $($ )Empreendedor & $($ )Consultor do Processo AQUA \\
\hline Outros (especificar) \\
\hline
\end{tabular}

17. Quais das partes contratadas têm profissionais com conhecimento sobre o Processo AQUA?

\begin{tabular}{|l|l|l|l|}
\hline ( ) Consultoria & $($ ) Arquitetura & $($ )Construtora & ( ) Engenharia \\
\hline ( $)$ Empreendedor & ( ) Incorporadora & ( ) Outros (especificar) & \\
\hline
\end{tabular}

18. Quais são ou foram as maiores dificuldades em relação à documentação exigida pelo Processo AQUA? Documento de comprometimento, perfil de qualidade ambiental, contratos, documentos gestão, documentos do empreendimento, declarações de legalidade trabalhista

19. Quais são os entraves ou barreiras internas e externas para a implementação da certificação do Processo AQUA?

20. Na sua opinião, como poderia ter sido implantado o Processo AQUA de maneira mais eficaz antes e durante a construção?

21. Em que medida o Processo AQUA afetou o processo de projeto, execução e produto final (edifício) ?

1-Muito pior, 2-Um pouco pior, 3-Similar, 4-Um pouco melhor, 5-Muito melhor

Projeto

Execução

Produto final (edifício)

22.Indique, Qual o grau de dificuldade em atingir as categorias exigidas pelo Processo AQUA

1- Muito fácil, 2- Fácil, 3- Indiferente, 4- Difícil, 5- Muito difícil

Relação do edificio com seu entorno

Escolha integrada de produtos, sistemas e processos construtivos

Canteiros de obras com baixo impacto ambiental

Gestão da energia

Gestão da agua

Gestao de residuos de uso e operação do edificio

Manutenção permanencia do desempenho ambiental

Conforto higrotermico

Conforto acustico

Conforto olfativo

Conforto visual

Qualidade sanitaria dos ambientes

Qualidade sanitaria do ar

Qualidade sanitaria da agua

23. Indique o grau de de importância, de cada uma das categorias consideradas no projeto 1-Muito importante, 2- Importante, 3- Indiferente, 4- Sem importância, 5- Nada importante 
Relação do edificio com seu entorno

Escolha integrada de produtos, sistemas e processos construtivos

Canteiros de obras com baixo impacto ambiental

Gestão da energia

Gestão da agua

Gestao de residuos de uso e operação do edificio

Manutenção permanencia do desempenho ambiental

Conforto higrotermico

Conforto acustico

Conforto olfativo

Conforto visual

Qualidade sanitaria dos ambientes

Qualidade sanitaria do ar

Qualidade sanitaria da agua

24. Indique as categorias que demandaram maior cuidado durante o projeto e a obra gerando impactos sobre os cronogramas de entrega do edifício

1- Não atraso,2- Pouco atraso, 3- Indiferente, 4- Difícil, 5- Muito difícil

Relação do edificio com seu entorno

Escolha integrada de produtos, sistemas e processos construtivos

Canteiros de obras com baixo impacto ambiental

Gestão da energia

Gestão da agua

Gestao de residuos de uso e operação do edificio

Manutenção permanencia do desempenho ambiental

Conforto higrotermico

Conforto acustico

Conforto olfativo

Conforto visual

Qualidade sanitaria dos ambientes

Qualidade sanitaria do ar

Qualidade sanitaria da agua

\section{6: Evolução da certificação}

25. Na sua opinião, como poderia ser melhorado o processo de certificação?

Menos burocracia / interface on-line

Simplificar a documentação e certificação

Integrar melhor as fases de projeto e de construção

Melhor atendimento ao cliente e feedback

Mais marketing para o mercado imobiliário

Outros (comentar)

\section{Sugestoes/comentarios}


Muito obrigado pela sua colaboração. 


\section{QUESTIONÁRIO PARA O PROFESSIONAL LEED AP}
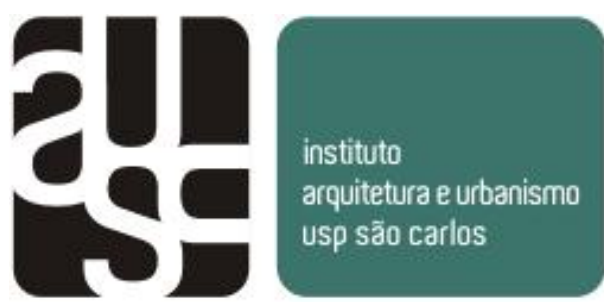

IAU-USP /Área de Tecnologia do Instituto de Arquitetura e Urbanismo da Universidade de São Paulo

\section{QUESTIONÁRIO-PROFISSIONAL CREDENCIADO LEED}

Este questionário tem objetivos estritamente acadêmicos e apóia a realização de uma tese de mestrado. Agradecemos sua colaboração no preenchimento de cada um dos campos de resposta deste questionário.

\section{1:Dados gerais}

Nome Telefone

Função e cargo

1. Você é um Professional credenciado LEED?Se a resposta for sim, há quanto tempo?

2. Quantos anos de experiência você tem, em construção de edifícios?

3. Em quantos empreendimentos certificados, você já participou?

4. Empreendimento e localização

5. Uso do empreendimento

\begin{tabular}{|l|l|l|l|}
\hline Escritórios & Comercial & Cospital & Loja \\
\hline B Banco & $\ldots$ Restaurant & Outros especificar__ \\
\hline
\end{tabular}

6. Concluiu o processo de certificação

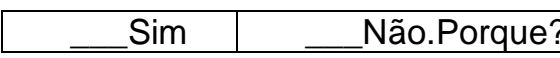

7. Se a resposta foi não à pergunta $n / 11$, é ainda a meta alcançar a certificação

\begin{tabular}{|l|l}
\hline $\operatorname{Sim}$ & Não.Porque? \\
\hline
\end{tabular}

8. Qual é o nível de certificação do empreendimento?Por quê?

\begin{tabular}{|c|l|l|l|}
\hline _Platina & _ Ouro & _ Prata & _Certificado \\
\hline
\end{tabular}

\section{2:Dados gerais}

9. Indique o motivo mais importante para a obtenção da certificação?

Gestão ambiental

Tomar como prioridade a construção sustentável

Validar a realização através da análise de terceiros

Vantagem competitiva 
Exigência do governo

Incentivos do governo local, estadual, federal

Oportunidades de lucro

A empresa emprega a sustentabilidade na estratégia de seus negócios

Exigências dos clientes e outras partes interessadas

Redução dos custos de operação

Melhoria da imagem

Acesso a novos mercados

Buscar estabelecer um padrão ou dar o exemplo

Melhorar a qualidade de vida de seus ocupantes

Melhorar o resultado final (melhor produto/edifício)

10. Entre as opções abaixo, indique cada quesito que, em sua opinião, são os principais motivos para a obtenção da certificação. Indique, qual o grau de importância de cada um desses fatores 1: Sem importância; 2: Pouco importante; 3: Regularmente importante; 4: Importante; 5: Muito importante.

Gestão ambiental

Tomar como prioridade a construção sustentável

Validar a realização através da análise de terceiros

Vantagem competitiva

Exigência do governo

Incentivos do governo local, estadual, federal

Oportunidades de lucro

A empresa emprega a sustentabilidade na estratégia de seus negócios

Exigências dos clientes e outras partes interessadas

Redução dos custos de operação

Melhoria da imagem

Acesso a novos mercados

Buscar estabelecer um padrão ou dar o exemplo

Melhorar a qualidade de vida de seus ocupantes

Melhorar o resultado final (melhor produto/edifício)

Outros (comentar)

\section{3: Benefícios da implementação do LEED}

11. Indique o beneficio mais importante para a obtenção da certificação?

Redução dos custos de investimento, operação e manutenção

Benefícios econômicos

Redução de danos, preservação e recuperação do meio ambiente

Tornam os empreendimentos mais atraentes o que garante um maior valor agregado Imagem, diferenciação e valorização do produto (empreendimento)

Redução dos riscos

Mais produtividade, conforto e saúde do usuário 
Novas oportunidades de negócios

Publicidade (ganhos em mídia gratuita)

Melhora a qualidade do processo de construção e de seus produtos (empreendimento)

Validar a realização através da analise de terceiros

Aumenta as vendas no varejo

Benefícios em custo de infra-estrutrua

Criação de emprego

12. Quais são os benefícios que você recebe ou pretende receber, para sua construção sustentável? Indique, qual o grau de importância de cada um desses fatores 1: Sem importância; 2: Pouco importante; 3: Regularmente importante; 4: Importante; 5: Muito importante.

Redução dos custos de investimento, operação e manutenção

Benefícios econômicos

Redução de danos, preservação e recuperação do meio ambiente

Tornam os empreendimentos mais atraentes o que garante um maior valor agregado

Imagem, diferenciação e valorização do produto (empreendimento)

Redução dos riscos

Mais produtividade, conforto e saúde do usuário

Novas oportunidades de negócios

Publicidade (ganhos em mídia gratuita)

Melhora a qualidade do processo de construção e de seus produtos (empreendimento)

Validar a realização através da analise de terceiros

Aumenta as vendas no varejo

Benefícios em custo de infra-estrutrua

Criação de emprego

Outros (comentar)

\section{4: Limitações da certificação LEED}

13. Indique a dificuldade mais difícil para a obtenção da certificação?

Documentação LEED / Burocracia excessiva

Obter a documentação LEED necessária dos (fornecedores, projetistas, construtora, consultores)

Comunicação/desentendimento com o USGBC

Falta de integração no processo de projeto

Pouca integração e falta de cooperação entre os agentes envolvidos (cliente, arquiteto, projetistas, construtora, consultores etc.)

Falta de cooperação entre equipes (agentes envolvidos)

Falta de fornecedores especializados para os insumos (materiais e tecnologias

sustentáveis) que o empreendimento demanda ou demandou

Mudanças do escopo do projeto

Rotatividade da equipe de projeto 


\section{Equipe ineficaz}

Falta de conhecimento dos integrantes da equipe

Falta de experiência dos integrantes da equipe do projeto (formação insuficiente) acerca do LEED e empreendimentos verdes

Falta pessoal treinado-operarios (mão de obra qualificada)

Taxa ou custo direto da certificação

Custo da documentação

_ Custo das tecnologias sustentáveis empreendidas no projeto e da mão de obra especializada

Alto custo empregado para o projeto-execução do empreendimento verde

Dificuldade em recuperar os custos iniciais

Complexidade das simulações energéticas e dos ensaios com materiais

Clima e localização regional do empreendimento

Falta de adequação das normas internacionais às regionais

Resistência dos projetistas e da construtora em implantar efetivamente algumas exigências (das categorias) solicitadas pela certificação LEED

Falta de comprometimento e empenho dos agentes

Questões relacionadas aos confortos térmicos, acústico e luminico

Tempo necessário para implementar práticas de sustentabilidade com base nos

requisitos do LEED

Dificuldade em satisfazer os pré-requisitos do LEED

Dificuldade em qualificar para a certificação LEED desejada

Convencer as partes interessadas a buy-in para o LEED

14. Quais as principais dificuldades encontradas ao longo do processo de implementação da certificação LEED? Indique, qual o grau de dificuldade de cada um desses fatores 1: Sem dificuldade; 2: Pouco difícil; 3: Regularmente difícil; 4: Difícil; 5: Muito difícil.

Documentação LEED / Burocracia excessiva

Obter a documentação LEED necessária dos (fornecedores, projetistas, construtora, consultores)

_Comunicação/desentendimento com o USGBC

Falta de integração no processo de projeto

_Pouca integração e falta de cooperação entre os agentes envolvidos (cliente, arquiteto, projetistas, construtora, consultores etc.)

Falta de cooperação entre equipes (agentes envolvidos)

Falta de fornecedores especializados para os insumos (materiais e tecnologias

sustentáveis) que o empreendimento demanda ou demandou

Mudanças do escopo do projeto

Rotatividade da equipe de projeto

Equipe ineficaz

Falta de conhecimento dos integrantes da equipe 
Falta de experiência dos integrantes da equipe do projeto (formação insuficiente) acerca do LEED e empreendimentos verdes

Falta pessoal treinado-operarios (mão de obra qualificada)

Taxa ou custo direto da certificação

Custo da documentação

_ Custo das tecnologias sustentáveis empreendidas no projeto e da mão de obra especializada

Alto custo empregado para o projeto-execução do empreendimento verde

Dificuldade em recuperar os custos iniciais

Complexidade das simulações energéticas e dos ensaios com materiais

Clima e localização regional do empreendimento

Falta de adequação das normas internacionais às regionais

Resistência dos projetistas e da construtora em implantar efetivamente algumas exigências (das categorias) solicitadas pela certificação LEED

Falta de comprometimento e empenho dos agentes

Questões relacionadas aos confortos térmicos, acústico e luminico

Tempo necessário para implementar práticas de sustentabilidade com base nos

requisitos do LEED

Dificuldade em satisfazer os pré-requisitos do LEED

Dificuldade em qualificar para a certificação LEED desejada

Convencer as partes interessadas a buy-in para o LEED

Outras (comentar)

15. Você pode comentar livremente as dificuldades mencionadas

\section{5: Processo de certificação LEED}

16. De quem surgiu a idéia de certificar com o LEED o empreendimento?

\begin{tabular}{|l|l|c|}
\hline$($ )Incorporador & $($ )Arquiteto & ( )Proprietário \\
\hline ( $)$ Empreendedor & ( )Profissional credenciado LEED \\
\hline ( $)$ Consultor & Outro (especificar) \\
\hline
\end{tabular}

17. Em que fase se decidiu pela certificação LEED?

\begin{tabular}{|c|c|c|}
\hline ( )Programa & ( )Concepção do projeto & ( )Detalhamento do projeto \\
\hline
\end{tabular}

18. Quanto foi o custo adicional (\% ou $R \$$ ) associado à implementação da certificação LEED no:

\begin{tabular}{|l|l|l|l|}
\hline$($ )Projeto & $($ ) Consultoria & $($ )Execução & $($ Certificação \\
\hline$($ ) Consultores & $($ ) Materiais & $($ )Ensaios & $($ Operacionais \\
\hline ( $)$ Outros (especificar) & \\
\hline
\end{tabular}


19. Quanto foi o custo adicional em relação a uma edificação convencional (custos do projeto, construção e operação)?\% ou $\mathrm{R} \$$

20. Da lista a seguir, selecione os que trabalharam com o LEED antes de seu envolvimento com o projeto LEED registrado

\begin{tabular}{|l|l|l|l|}
\hline ( )Empresa fiscalizadora & ( )Arquiteto & ( )Construtora & ( )Engenheiro \\
\hline ( )Consultores & ( )Empreendedor & ( )Outros (especificar) \\
\hline
\end{tabular}

21. Quais das partes contratadas têm profissionais com conhecimento sobre certificação LEED?

\begin{tabular}{|l|l|l|l|}
\hline ( $)$ Fiscal & $($ )Arquitetura & $($ )Construtora & $($ Engenharia \\
\hline ( $)$ Consultoria & $($ )Empreendedor & $($ ) Incorporadora & \\
\hline ( )Outros (especificar) \\
22. Qual a principal dificuldade com os projetistas, empresa fiscalizadora,
\end{tabular}
proprietário,empreendedor,incorporador, fornecedores, construtora?

23. Quem ficou responsável por orientar as decisões, fornecer informações sobre o processo de certificação, elaborar e organizar a documentação exigida pelo USGBC?

\begin{tabular}{|l|l|l|l|}
\hline ( ) Empresa fiscalizadora & $($ )Arquiteto & $($ ) Construtora & $($ )Engenheiro \\
\hline $\begin{array}{l}\text { ( )Profissional } \\
\text { credenciado LEED }\end{array}$ & $($ )Empreendedor & $($ )Gerente de comissionamento \\
\hline ( )Outros (especificar) & \multicolumn{3}{|l}{} \\
\hline
\end{tabular}

24. Quais são as maiores dificuldades em relação à documentação exigida pela certificação LEED? projetos, memoriais,contratos e relatórios?

25. Como foi coordenada a documentação LEED?

\begin{tabular}{|l|l|l|l|}
\hline ( )Planilhas excel & ( )Softwares & ( )Papel & ( )Não documentado \\
\hline
\end{tabular}

26. Quais são os entraves ou barreiras internas e externas para a implementação da certificação LEED?

27. Como poderia ter sido implantada a certificação LEED de maneira mais eficaz antes e durante a construção?

28. Em que medida a certificação LEED afetou o processo de projeto, execução e produto final (edifício) ?

1-Muito pior, 2-Um pouco pior, 3-Similar, 4-Um pouco melhor, 5-Muito melhor

$$
\text { Projeto }
$$

Execução

Produto final (edifício)

29. Na tabela a seguir indique: O grau de de importância, de cada uma das categorias consideradas no projeto

1:Muito importante, 2: Importante, 3: Regularmente importante, 4:Pouco importante, 5:Sem importancia 
Terrenos sustentaveis

Uso racional da água

Energia e atmosfera

Materiais e recursos

Qualidade do ambiente interno

Projeto e inovação

30. Na tabela a seguir indique: $\mathrm{O}$ grau de dificuldade em atingir as categorias exigidas pela certificação LEED

1:Muito fácil, 2:Fácil, 3:Indiferente, 4:Difícil, 5:Muito difícil

Terrenos sustentaveis

Uso racional da água

Energia e atmosfera

Materiais e recursos

Qualidade do ambiente interno

Projeto e inovação

31. Na tabela a seguir indique: As categorias que demandaram maior cuidado durante o projeto e a obra gerando impactos sobre os cronogramas de entrega do edifício

1:Não atraso,2:Pouco atraso, 3:Indiferente, 4:Difícil, 5:Muito difícil

Terrenos sustentaveis

Uso racional da água

Energia e atmosfera

Materiais e recursos

Qualidade do ambiente interno

Projeto e inovação

\section{6: Evolução da certificação}

32. Na sua opinião, como poderia ser melhorado o processo de certificação?

Menos burocracia / interface on-line

Simplificar a documentação e certificação

Integrar melhor as fases de projeto e de construção

Melhor atendimento ao cliente e feedback

Mais marketing para o mercado imobiliário

Outros (comentar)

Sugestoes/comentarios

Muito obrigado pela sua colaboração. 


\section{QUESTIONÁRIO PARA O CONSULTOR DO PROCESSO AQUA}

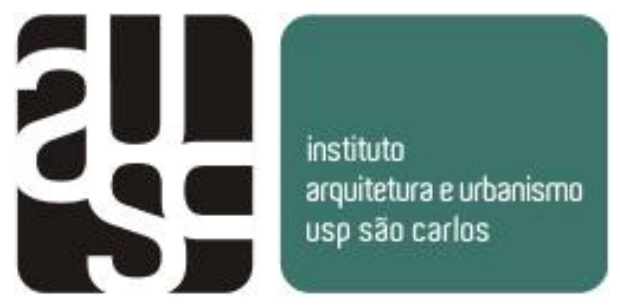

IAU-USP /Área de Tecnologia do Instituto de Arquitetura e Urbanismo da

Universidade de São Paulo

\section{QUESTIONÁRIO-CONSULTOR DO PROCESSO AQUA}

Este questionário tem objetivos estritamente acadêmicos e apóia a realização de uma tese de mestrado. Agradecemos sua colaboração no preenchimento de cada um dos campos de resposta deste questionário.

\section{1:Dados gerais}

Nome Telefone

Função e cargo

1. Você é um consultor AQUA?Se a resposta for sim, há quanto tempo?

2. Quantos anos de experiência você tem, em construção de edifícios?

3. Em quantos empreendimentos certificados, você já participou?

4. Empreendimento e localização

5. Uso do empreendimento

\begin{tabular}{|l|l|l|l|}
\hline Escritórios & C Comercial & Hospital & Loja \\
\hline Banco & $\ldots$ Restaurant & Outros especificar___ \\
\hline
\end{tabular}

6. Ate que fase foi certificado o edifício?

\begin{tabular}{|l|l|l|}
\hline _ Programa & _Concepção & _Realização \\
\hline
\end{tabular}

\section{2: Motivações}

7. Indique o motivo mais importante para a obtenção da certificação?

Gestão ambiental

Tomar como prioridade a construção sustentável

Validar a realização através da análise de terceiros

Vantagem competitiva

Exigência do governo

Incentivos do governo local, estadual, federal

Oportunidades de lucro

A empresa emprega a sustentabilidade na estratégia de seus negócios

Exigências dos clientes e outras partes interessadas 
Redução dos custos de operação

Melhoria da imagem

Acesso a novos mercados

Buscar estabelecer um padrão ou dar o exemplo

Melhorar a qualidade de vida de seus ocupantes

Melhorar o resultado final (melhor produto/edifício)

8. Entre as opções abaixo, indique cada quesito que, em sua opinião, são os principais motivos para a obtenção da certificação. Indique, qual o grau de importância de cada um desses fatores 1: Sem importância; 2: Pouco importante; 3: Regularmente importante; 4: Importante; 5: Muito importante.

Gestão ambiental

Tomar como prioridade a construção sustentável

Validar a realização através da análise de terceiros

Vantagem competitiva

Exigência do governo

Incentivos do governo local, estadual, federal

Oportunidades de lucro

A empresa emprega a sustentabilidade na estratégia de seus negócios

Exigências dos clientes e outras partes interessadas

Redução dos custos de operação

Melhoria da imagem

Acesso a novos mercados

Buscar estabelecer um padrão ou dar o exemplo

Melhorar a qualidade de vida de seus ocupantes

Melhorar o resultado final (melhor produto/edifício)

Outros (comentar)

\section{3: Benefícios da implementação do Processo AQUA}

9. Indique o beneficio mais importante para a obtenção da certificação?

Redução dos custos de investimento, operação e manutenção

Benefícios econômicos

Redução de danos, preservação e recuperação do meio ambiente

Tornam os empreendimentos mais atraentes o que garante um maior valor agregado

Imagem, diferenciação e valorização do produto (empreendimento)

Redução dos riscos

Mais produtividade, conforto e saúde do usuário

Novas oportunidades de negócios

Publicidade (ganhos em mídia gratuita)

Melhora a qualidade do processo de construção e de seus produtos (empreendimento)

Validar a realização através da analise de terceiros

Aumenta as vendas no varejo 


\section{Benefícios em custo de infra-estrutrua}

Criação de emprego

10. Quais são os benefícios que você recebe ou pretende receber da implementação do Processo AQUA para este empreendimento? Indique, qual o grau de importância de cada um desses fatores 1: Sem importância; 2: Pouco importante; 3: Regularmente importante; 4: Importante; 5: Muito importante.

Redução dos custos de investimento, operação e manutenção

Benefícios econômicos

Redução de danos, preservação e recuperação do meio ambiente

Tornam os empreendimentos mais atraentes o que garante um maior valor agregado Imagem, diferenciação e valorização do produto (empreendimento)

Redução dos riscos

Mais produtividade, conforto e saúde do usuário

Novas oportunidades de negócios

Publicidade (ganhos em mídia gratuita)

Melhora a qualidade do processo de construção e de seus produtos (empreendimento)

Validar a realização através da analise de terceiros

Aumenta as vendas no varejo

Benefícios em custo de infra-estrutrua

Criação de emprego

Outros (comentar)

\section{4: Limitações do Processo AQUA}

11. Indique a dificuldade mais difícil para a obtenção da certificação?

Documentação / Burocracia excessiva

Obter a documentação necessária dos (fornecedores, projetistas, construtora, consultores)

Comunicação/desentendimento com a FCAV

Falta de integração no processo de projeto

Pouca integração e falta de cooperação entre os agentes envolvidos (cliente, arquiteto, projetistas, construtora, consultores etc.)

Falta de cooperação entre equipes (agentes envolvidos)

Falta de fornecedores especializados para os insumos (materiais e tecnologias

sustentáveis) que o empreendimento demanda ou demandou

Mudanças do escopo do projeto

Rotatividade da equipe de projeto

Equipe ineficaz

Falta de conhecimento dos integrantes da equipe

Falta de experiência dos integrantes da equipe do projeto (formação insuficiente) acerca do Processo AQUA e empreendimentos verdes

Falta pessoal treinado-operarios (mão de obra qualificada) 
Taxa ou custo direto da certificação

Custo da documentação

_ Custo das tecnologias sustentáveis empreendidas no projeto e da mão de obra especializada

Alto custo empregado para o projeto-execução do empreendimento verde

Dificuldade em recuperar os custos iniciais

Complexidade das simulações energéticas e dos ensaios com materiais

Clima e localização regional do empreendimento

Falta de adequação das normas internacionais às regionais

Resistência dos projetistas e da construtora em implantar efetivamente algumas exigências (das categorias) solicitadas pelo Processo AQUA

Falta de comprometimento e empenho dos agentes

Questões relacionadas aos confortos térmicos, acústico e luminico

_ Tempo necessário para implementar práticas de sustentabilidade com base nos requisitos do Processo AQUA

Dificuldade em satisfazer as categorias do Processo AQUA

Dificuldade em qualificar para nivel desejado

Convencer as partes interessadas a buy-in para o Processo AQUA

12. Quais as principais dificuldades encontradas ao longo do processo de implementação do Processo AQUA? Indique, qual o grau de dificuldade de cada um desses fatores 1: Sem dificuldade; 2: Pouco difícil; 3: Regularmente difícil; 4: Difícil; 5: Muito difícil.

Documentação / Burocracia excessiva

Obter a documentação necessária dos (fornecedores, projetistas, construtora, consultores)

Comunicação/desentendimento com a FCAV

Falta de integração no processo de projeto

Pouca integração e falta de cooperação entre os agentes envolvidos (cliente, arquiteto, projetistas, construtora, consultores etc.)

Falta de cooperação entre equipes (agentes envolvidos)

Falta de fornecedores especializados para os insumos (materiais e tecnologias

sustentáveis) que o empreendimento demanda ou demandou

Mudanças do escopo do projeto

Rotatividade da equipe de projeto

Equipe ineficaz

Falta de conhecimento dos integrantes da equipe

Falta de experiência dos integrantes da equipe do projeto (formação insuficiente) acerca do Processo AQUA e empreendimentos verdes

Falta pessoal treinado-operarios (mão de obra qualificada)

Taxa ou custo direto da certificação

Custo da documentação 
Custo das tecnologias sustentáveis empreendidas no projeto e da mão de obra especializada

Alto custo empregado para o projeto-execução do empreendimento verde

Dificuldade em recuperar os custos iniciais

Complexidade das simulações energéticas e dos ensaios com materiais

Clima e localização regional do empreendimento

Falta de adequação das normas internacionais às regionais

Resistência dos projetistas e da construtora em implantar efetivamente algumas exigências (das categorias) solicitadas pelo Processo AQUA

Falta de comprometimento e empenho dos agentes

Questões relacionadas aos confortos térmicos, acústico e luminico

Tempo necessário para implementar práticas de sustentabilidade com base nos requisitos do Processo AQUA

Dificuldade em satisfazer as categorias do Processo AQUA

Dificuldade em qualificar para nivel desejado

Convencer as partes interessadas a buy-in para o Processo AQUA

Outras (comentar)

13. Você pode comentar livremente as dificuldades mencionadas

\section{5: Processo de certificação}

14. De quem surgiu a idéia de certificar com o Processo AQUA o empreendimento?

\begin{tabular}{|l|l|l|}
\hline$($ )Incorporador & $($ )Arquiteto & $($ )Proprietário \\
\hline ( )Empreendedor & ( )Consultor \\
\hline \multicolumn{2}{|l}{ Outro (especificar) }
\end{tabular}

15. Em que fase se decidiu pela certificação do Processo AQUA?

\begin{tabular}{|l|l|l|}
\hline ( )Programa & ( )Concepção do projeto & ( )Detalhamento do projeto \\
\hline ( )Execução da obra
\end{tabular}

16. Quais foram as dificuldades enfrentadas por você ao implementar o SGE e avaliar o QAE?

17. Da lista a seguir, selecione os que trabalharam com o Processo AQUA antes de seu envolvimento com o projeto

\begin{tabular}{|l|l|l|l|}
\hline ( )Empresa fiscalizadora & ( )Arquiteto & ( )Construtora & ( )Engenheiro \\
\hline ( )Consultores & ( )Empreendedor & ( )Outros (especificar) \\
\hline
\end{tabular}

18. Quais das partes contratadas tem um consultor com conhecimento sobre o Processo AQUA?

\begin{tabular}{|l|l|l|l|}
\hline ( )Incorporadora & $($ )Arquitetura & $($ )Construtora & $($ Engenharia \\
\hline ( )Consultoria & ( )Empreendedor & $($ ) Empresa fiscalizadora \\
\hline ( )Outros (especificar)
\end{tabular}


19. Quem ficou responsável do fluxo de informações entre projetistas especialistas e empreendedor de estruturar os documentos exigidos pelo processo de certificação AQUA?

\begin{tabular}{|l|l|l|l|}
\hline ( )Empresa fiscalizadora & ( )Arquiteto & $($ )Construtora & $($ Engenheiro \\
\hline ( )Consultor AQUA & ( )Empreendedor & & \\
\hline ( ) Outros (especificar)
\end{tabular}

20. Como foi coordenada a documentação?

\begin{tabular}{|l|l|l|l|}
\hline ( )Planilhas excel & ( )Softwares & ( )Papel & ( )Não documentado \\
\hline
\end{tabular}

21. Quais são as maiores dificuldades em relação à documentação exigida pelo Processo AQUA? projetos, memoriais,contratos e relatórios?

22. Quanto foi o custo adicional (\% ou $R \$$ ) associado à implementação do Processo $A Q U A$ no:

\begin{tabular}{|c|c|c|c|c|}
\hline ( & Projeto & ( )Consultoria & ( ) Execução & ( )Certificação \\
\hline ( & Consultores & ( )Materiais & ( ) Ensaios & ( )Operacionais \\
\hline
\end{tabular}

23. Quanto foi o custo adicional em relação a uma edificação convencional (custos do projeto, construção e operação)?\% ou $R \$$

24. Qual a principal dificuldade com os projetistas, empresa fiscalizadora, proprietário,empreendedor,incorporador, fornecedores, construtora?

25. Quais são os entraves ou barreiras internas e externas para a implementação do Processo AQUA?

26. Como poderia ter sido implantado o Processo AQUA de maneira mais eficaz antes e durante a construção?

27. Em que medida o Processo AQUA afetou o processo de projeto, execução e produto final (edifício) ? 1-Muito pior, 2-Um pouco pior, 3-Similar, 4-Um pouco melhor, 5-Muito melhor Projeto

\section{Execução}

Produto final (edifício)

28. Indique: Qual o grau de de importância, de cada uma das categorias consideradas no projeto

1:Muito importante, 2:Importante, 3:Indiferente, 4:Sem importância, 5:Nada importante

Relação do edificio com seu entorno

Escolha integrada de produtos, sistemas e processos construtivos

Canteiros de obras com baixo impacto ambiental

Gestão da energia

Gestão da agua

Gestao de residuos de uso e operação do edificio

Manutenção permanencia do desempenho ambiental

Conforto higrotermico

Conforto acustico

Conforto olfativo

Conforto visual 
Qualidade sanitaria dos ambientes

Qualidade sanitaria do ar

Qualidade sanitaria da agua

29.Indique, Qual o grau de dificuldade em atingir as categorias exigidas pelo Processo AQUA

1:Muito fácil, 2:Fácil, 3:Indiferente, 4:Difícil, 5:Muito difícil

Relação do edificio com seu entorno

Escolha integrada de produtos, sistemas e processos construtivos

Canteiros de obras com baixo impacto ambiental

Gestão da energia

Gestão da agua

Gestao de residuos de uso e operação do edificio

Manutenção permanencia do desempenho ambiental

Conforto higrotermico

Conforto acustico

Conforto olfativo

Conforto visual

Qualidade sanitaria dos ambientes

Qualidade sanitaria do ar

Qualidade sanitaria da agua

30. As categorias que demandaram maior cuidado durante o projeto e a obra gerando impactos sobre os cronogramas de entrega do edifício

1:Não atraso,2:Pouco atraso, 3:Indiferente, 4:Difícil, 5:Muito difícil

Relação do edificio com seu entorno

Escolha integrada de produtos, sistemas e processos construtivos

Canteiros de obras com baixo impacto ambiental

Gestão da energia

Gestão da agua

Gestao de residuos de uso e operação do edificio

Manutenção permanencia do desempenho ambiental

Conforto higrotermico

Conforto acustico

Conforto olfativo

Conforto visual

Qualidade sanitaria dos ambientes

Qualidade sanitaria do ar

Qualidade sanitaria da agua

\section{6: Evolução da certificação}

31. Na sua opinião, como poderia ser melhorado o processo de certificação?

Menos burocracia / interface on-line

Simplificar a documentação e certificação 
Integrar melhor as fases de projeto e de construção

Melhor atendimento ao cliente e feedback

_ Mais marketing para o mercado imobiliário

Outros (comentar)

Sugestoes/comentarios

Muito obrigado pela sua colaboração. 


\section{ANEXO B}

\section{EMPREENDEDORES LEED}

\begin{tabular}{|c|c|c|c|l|c|}
\hline $\begin{array}{c}\text { Número de } \\
\text { respondente }\end{array}$ & Nome & Telefone & Empresa & $\begin{array}{c}\text { Você é o proprietário ou investidor } \\
\text { do empreendimento? }\end{array}$ & $\begin{array}{c}\text { Em quantos } \\
\text { empreendime } \\
\text { ntos } \\
\text { certificados, } \\
\text { você iá } \\
\text { participou? }\end{array}$ \\
\hline & $\begin{array}{c}\text { Resposta } \\
\text { aberta }\end{array}$ & $\begin{array}{c}\text { Resposta } \\
\text { aberta }\end{array}$ & $\begin{array}{c}\text { Resposta } \\
\text { aberta }\end{array}$ & \multicolumn{1}{c|}{ Resposta fechada } & $\begin{array}{c}\text { Resposta } \\
\text { aberta }\end{array}$ \\
\hline 1 & $\mathrm{XXXX}$ & $\mathrm{XXXX}$ & $\mathrm{XXXX}$ & Não & 1 \\
\hline 2 & $\mathrm{XXXX}$ & $\mathrm{XXXX}$ & $\mathrm{XXXX}$ & Sim & 3 \\
\hline 3 & $\mathrm{XXXX}$ & $\mathrm{XXXX}$ & $\mathrm{XXXX}$ & Não, arquiteto coordenador do XXX & 3 \\
\hline 4 & $\mathrm{XXXX}$ & $\mathrm{XXXX}$ & $\mathrm{XXXX}$ & Não & 1 \\
\hline 5 & $\mathrm{XXXX}$ & $\mathrm{XXXX}$ & $\mathrm{XXXX}$ & Proprietário e também investidor & 1 \\
\hline 6 & $\mathrm{XXXX}$ & $\mathrm{XXXX}$ & $\mathrm{XXXX}$ & $\begin{array}{l}\text { Sim, a empresa possui um braço para } \\
\text { construção e investimento }\end{array}$ & 2 \\
\hline 7 & $\mathrm{XXXX}$ & $\mathrm{XXXX}$ & $\mathrm{XXXX}$ & Não & 2 \\
\hline
\end{tabular}

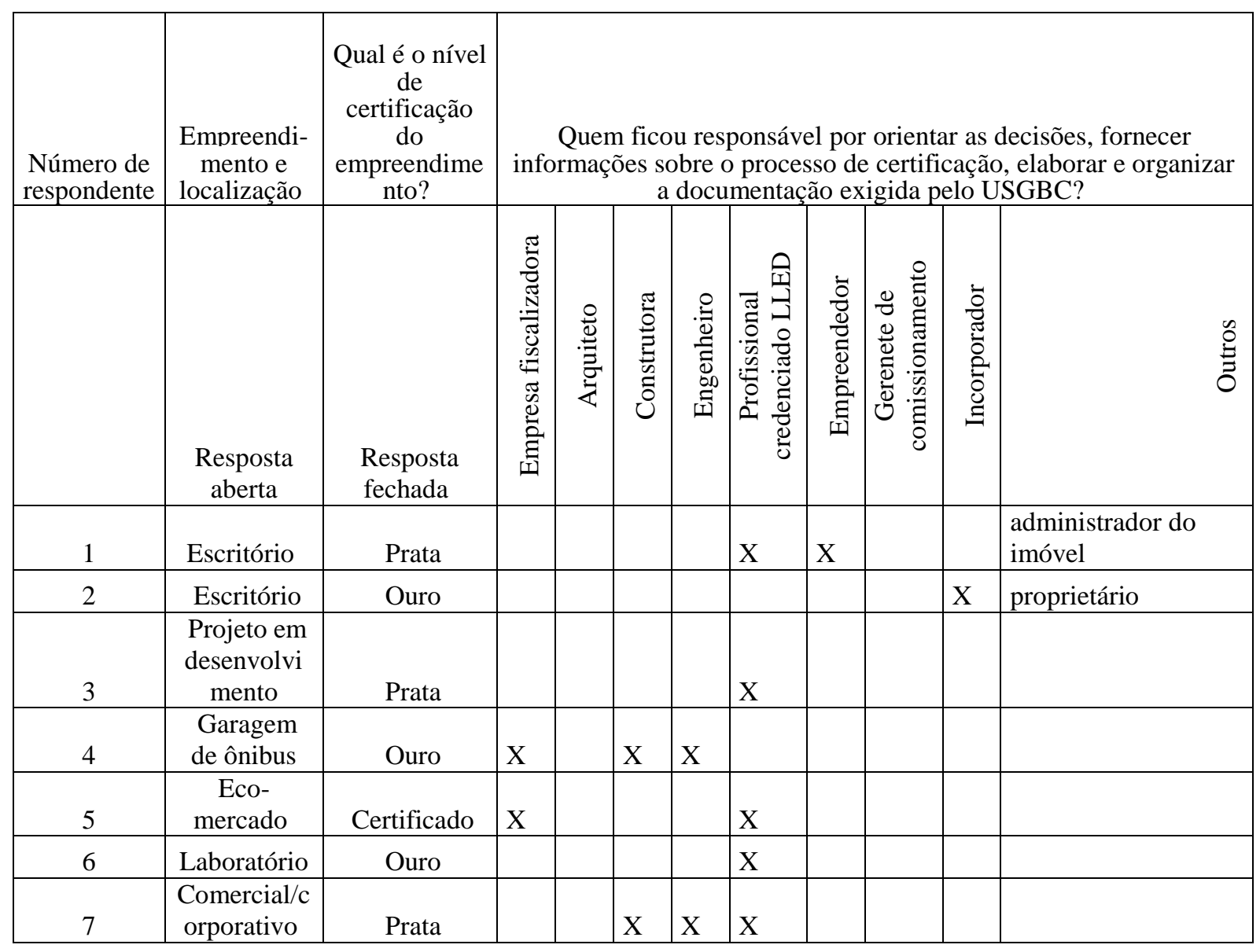




\begin{tabular}{|c|l|}
\hline $\begin{array}{c}\text { Número de } \\
\text { respondente }\end{array}$ & Indique o motivo mais importante para a obtenção da certificação? \\
\hline & Resposta aberta \\
\hline 1 & \\
\hline 2 & Melhorar o resultado final \\
\hline 3 & \\
\hline 4 & A empresa emprega a sustentabilidade na estratégia de seus negócios \\
\hline 5 & \\
\hline 6 & Exigências dos clientes e outras partes interessadas \\
\hline 7 & A empresa emprega a sustentabilidade na estratégia de seus negócios \\
\hline
\end{tabular}

\begin{tabular}{|c|c|c|c|c|c|c|c|c|c|c|c|c|c|c|c|c|}
\hline \multirow[t]{2}{*}{ 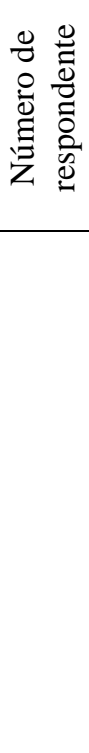 } & \multicolumn{16}{|c|}{$\begin{array}{l}\text { Entre as opções abaixo, indique (por ordem de importância) cada quesito que, em sua opinião, são os } \\
\text { principais motivos para a obtenção da certificação. }\end{array}$} \\
\hline & 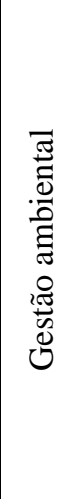 & 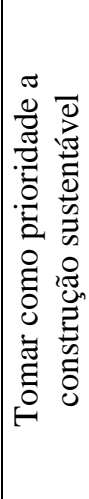 & 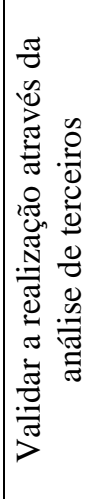 & 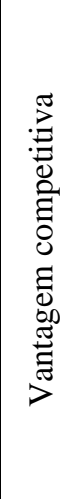 & 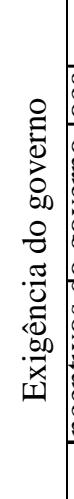 & 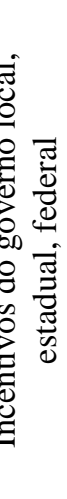 & 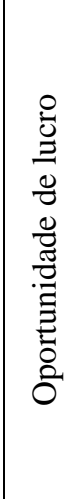 & 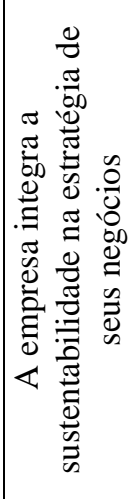 & 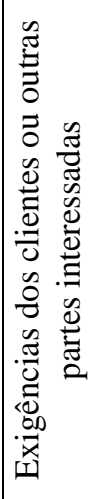 & 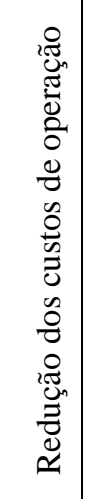 & 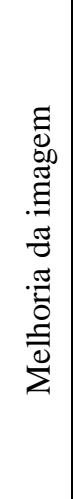 & 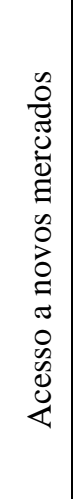 & 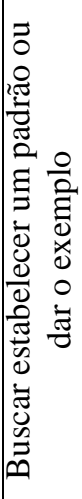 & 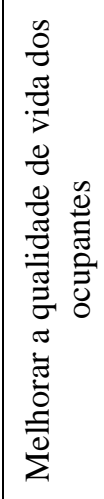 & 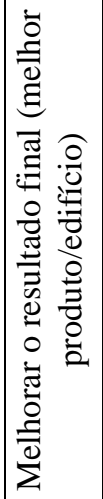 & 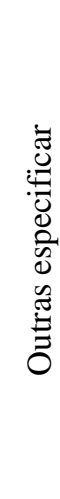 \\
\hline 1 & $\mathrm{I}$ & $\mathrm{I}$ & $\mathrm{RI}$ & MI & SI & SI & MI & MI & $\mathrm{RI}$ & I & MI & $\mathrm{I}$ & RI & $\mathrm{RI}$ & MI & \\
\hline 2 & I & I & MI & I & SI & SI & I & I & I & I & I & RI & I & I & MI & \\
\hline 3 & RI & RI & MI & MI & SI & SI & MI & MI & MI & I & MI & MI & MI & I & I & \\
\hline 4 & MI & MI & I & MI & RI & PI & RI & MI & RI & $\mathrm{MI}$ & MI & MI & MI & MI & RI & \\
\hline 5 & MI & MI & $\mathrm{I}$ & PI & PI & SI & SI & MI & $\mathrm{I}$ & SI & MI & MI & MI & MI & MI & \\
\hline 6 & MI & RI & PI & $\mathrm{I}$ & I & MI & MI & RI & $\mathrm{I}$ & MI & MI & $\mathrm{I}$ & RI & $\mathrm{RI}$ & $\mathrm{I}$ & \\
\hline 7 & I & I & RI & MI & I & $\mathrm{RI}$ & MI & MI & MI & MI & MI & MI & MI & MI & MI & \\
\hline
\end{tabular}




\begin{tabular}{|c|l|}
\hline $\begin{array}{c}\text { Número de } \\
\text { respondente }\end{array}$ & Indique o beneficio mais importante para a obtenção da certificação? \\
\hline & Resposta aberta \\
\hline 1 & \\
\hline 2 & Imagem, diferenciação e valorização do empreendimento \\
\hline 3 & \\
\hline 4 & Imagem, diferenciação e valorização do empreendimento \\
\hline 5 & \\
\hline 6 & Tornam os empreendimentos mais atraentes o que garante um maior valor agregado \\
\hline 7 & Imagem, diferenciação e valorização do empreendimento \\
\hline
\end{tabular}

\begin{tabular}{|c|c|c|}
\hline $\begin{array}{l}\text { Número de } \\
\text { respondente }\end{array}$ & $\begin{array}{l}\text { Quanto foi o custo adicional (\% ou R\$) } \\
\text { associado à implementação da certificação } \\
\text { LEED no: }\end{array}$ & $\begin{array}{l}\text { Quanto foi o custo adicional em relação a uma } \\
\text { edificação convencional (custos do projeto, } \\
\text { construção e operação)?\% ou R } \$\end{array}$ \\
\hline & Resposta aberta & Resposta aberta \\
\hline 1 & $\begin{array}{l}10 \% \text { certificação } \\
20 \% \text { consultoria } \\
70 \% \text { operacionais }\end{array}$ & $\begin{array}{l}\text { Diminui } 15 \% \text { do total de custos operacionais } \\
\text { com a certificação LEED EB }\end{array}$ \\
\hline 2 & $10 \%$ no total & $\begin{array}{l}\text { de } 5 \% \text { a } 20 \% \text { do total dependendo do produto } \\
\text { final }\end{array}$ \\
\hline 3 & Não tenho este dado & Não tenho este dado \\
\hline 4 & Aproximadamente $10 \%$ do valor geral da obra & Aproximadamente $10 \%$ do valor geral da obra \\
\hline 5 & $\begin{array}{l}\text { Certificação no valor total de: } \mathrm{R} \$ 86.000,00 \\
\text { diluídos em: } \\
\text { Consultoria: R\$ 54.000,00 } \\
\text { Projeto de finalização:R } \$ 27.000,000 \\
\text { Acompanhamento mensal: R\$ 54.000,00 } \\
\text { Fase pré-operação e pós-entrega: R } \$ 3.000,00 \\
\text { Obtenção da licença de operação:R } \$ 2.000,00 \\
\quad \text { Projeto: } 10 \% \\
\text { Materiais, ensaios e operações: } 15 \% \text { a mais } \\
\end{array}$ & $\begin{array}{c}\text { Para construir uma obra ecologicamente } \\
\text { correta não é barato, você gasta } 10 \% \text { a mais do } \\
\text { que uma obra comum. }\end{array}$ \\
\hline 6 & O custo adicional foi em torno de $18 \%$ & Os custos giram em torno de $20 \%$ \\
\hline 7 & $\begin{array}{l}\text { Para condomínio logístico tivemos um custo } \\
\text { adicional em torno de } 4 \% \text {, para edifício } \\
\text { comercial e corporativo ainda não estimamos, } \\
\text { estamos prevendo um custo adicional de até } \\
3 \% \text { (muitas das medidas solicitadas pelo LEED } \\
\text { como reuso de água, conforto ambiental já } \\
\text { utilizamos como padrão nossos } \\
\text { empreendimentos). }\end{array}$ & $\begin{array}{l}\text { Os custos das respostas anteriores são em } \\
\text { relação aos empreendimentos sem certificação } \\
\text { que já foram realizados pela construtora não } \\
\text { temos outra referencia }\end{array}$ \\
\hline
\end{tabular}




\begin{tabular}{|c|c|c|c|c|c|c|c|c|c|c|c|c|c|c|}
\hline \multirow[t]{2}{*}{ 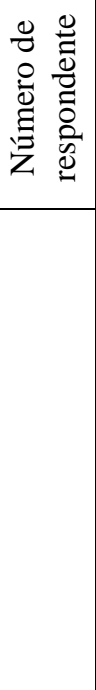 } & \multicolumn{14}{|c|}{ Quais são os benefícios que você recebe ou pretende receber, para sua construção sustentável? } \\
\hline & 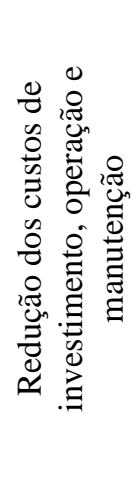 & 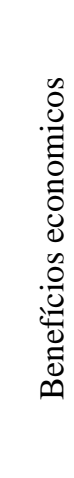 & 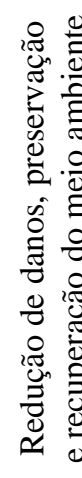 & 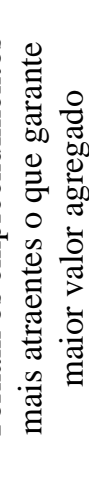 & 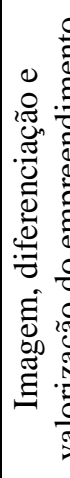 & 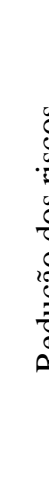 & 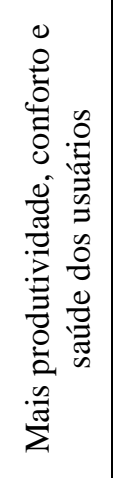 & 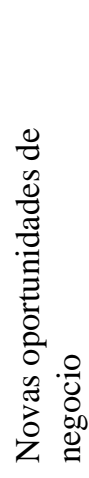 & 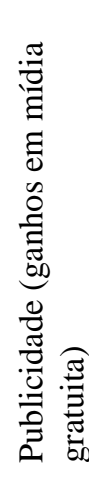 & 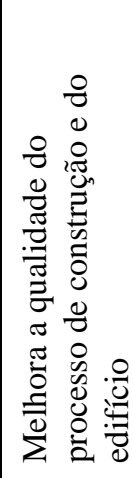 & 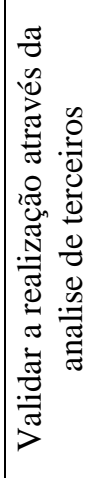 & 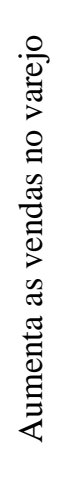 & 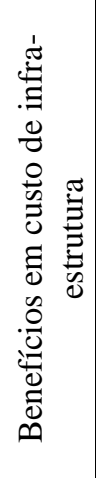 & 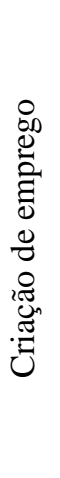 \\
\hline 1 & MI & RI & RI & MI & MI & I & $\mathrm{I}$ & $\mathrm{I}$ & $\mathrm{I}$ & MI & & & & \\
\hline 2 & I & I & I & MI & MI & RI & I & RI & RI & RI & MI & RI & RI & $\mathrm{RI}$ \\
\hline 3 & I & $\mathrm{I}$ & RI & MI & $\mathrm{MI}$ & $\mathrm{RI}$ & I & MI & MI & I & & & & \\
\hline 4 & MI & I & I & MI & MI & I & I & MI & MI & MI & RI & RI & I & I \\
\hline 5 & RI & SI & MI & MI & MI & $\mathrm{M}$ & MI & MI & I & MI & & & & \\
\hline 6 & MI & I & RI & I & MI & PI & RI & $\mathrm{I}$ & RI & I & PI & $\mathrm{RI}$ & PI & PI \\
\hline 7 & MI & MI & MI & MI & $\mathrm{MI}$ & $\mathrm{RI}$ & MI & MI & I & MI & MI & $\mathrm{I}$ & RI & $\mathrm{RI}$ \\
\hline
\end{tabular}




\begin{tabular}{|c|l|}
\hline $\begin{array}{c}\text { Número de } \\
\text { respondente }\end{array}$ & Indique a dificuldade mais difícil para a obtenção da certificação? \\
\hline & Resposta aberta \\
\hline 1 & \\
\hline 2 & Falta pessoal treinado-operarios (mão de obra qualificada) \\
\hline 3 & \\
\hline 4 & $\begin{array}{l}\text { Resistência dos projetistas e da construtora em implantar efetivamente algumas exigências } \\
\text { (das categorias) solicitadas pela certificação LEED }\end{array}$ \\
\hline 5 & \\
\hline 6 & Alto custo empregado para o projeto-execução do empreendimento verde \\
\hline 7 & Dificuldade em qualificar para a certificaçâo LEED desejada \\
\hline
\end{tabular}

\begin{tabular}{|c|c|c|c|c|c|c|c|c|c|c|c|c|c|c|}
\hline \multirow{2}{*}{ 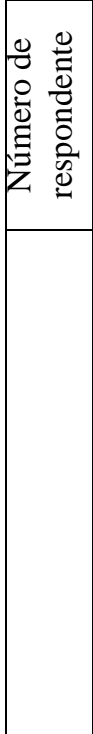 } & \multicolumn{14}{|c|}{ Quais são as principais dificuldades encontradas ao longo do processo de implementação da certificação LEED? } \\
\hline & 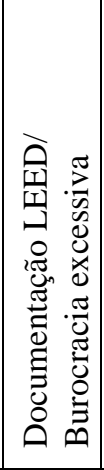 & 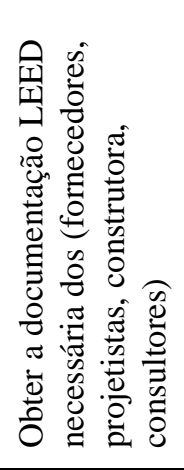 & 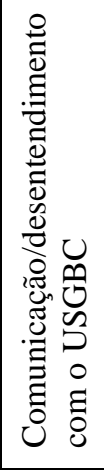 & 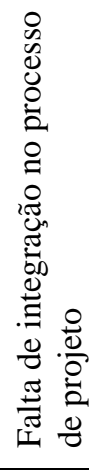 & 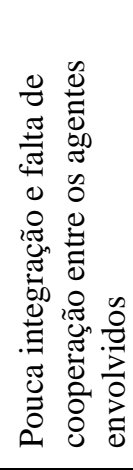 & 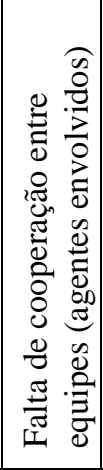 & 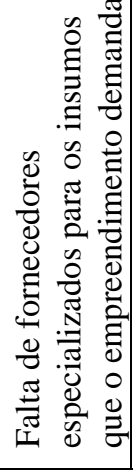 & 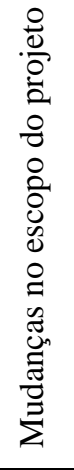 & 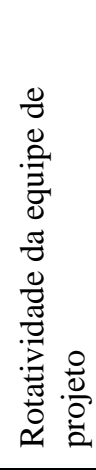 & 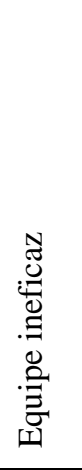 & 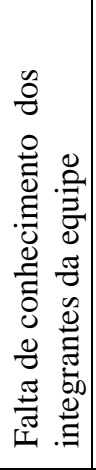 & 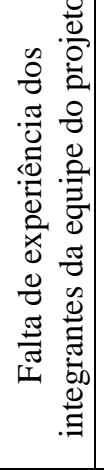 & 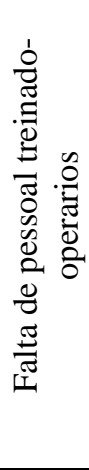 & 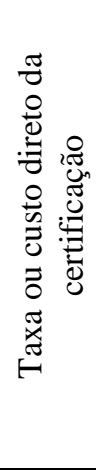 \\
\hline 1 & D & MD & RD & & PD & & MD & RD & PD & & MD & & & $\mathrm{D}$ \\
\hline 2 & MD & $\mathrm{D}$ & $\mathrm{D}$ & $\mathrm{D}$ & $\mathrm{RD}$ & $\mathrm{D}$ & $\mathrm{D}$ & $\mathrm{RD}$ & $\mathrm{RD}$ & $\mathrm{RD}$ & $\mathrm{RD}$ & $\mathrm{D}$ & MD & $\mathrm{RD}$ \\
\hline 3 & $\mathrm{RD}$ & $\mathrm{RD}$ & $\mathrm{RD}$ & & $\mathrm{RD}$ & & $\mathrm{RD}$ & SD & SD & & PD & & & \\
\hline 4 & D & MD & RD & $\mathrm{RD}$ & D & D & MD & MD & $\mathrm{RD}$ & $\mathrm{RD}$ & $\mathrm{D}$ & $\mathrm{D}$ & $\mathrm{D}$ & MD \\
\hline 5 & D & MD & MD & & SD & & SD & RD & PD & & SD & & & D \\
\hline 6 & $\mathrm{D}$ & MD & $\mathrm{PD}$ & $\mathrm{RD}$ & SD & PD & MD & MD & $\mathrm{PD}$ & $\mathrm{D}$ & $\mathrm{RD}$ & PD & D & $\mathrm{D}$ \\
\hline 7 & D & D & $\mathrm{RD}$ & MD & $\mathrm{RD}$ & PD & D & D & PD & PD & PD & PD & $\mathrm{RD}$ & D \\
\hline
\end{tabular}




\begin{tabular}{|c|c|c|c|c|c|c|c|c|c|c|c|}
\hline \multirow{2}{*}{ 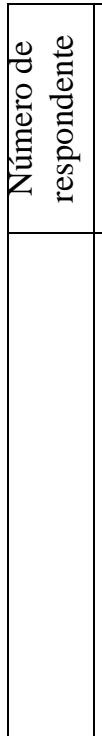 } & \multicolumn{11}{|c|}{$\begin{array}{l}\text { Quais são as principais dificuldades encontradas ao longo do processo de implementação da certificação } \\
\text { LEED? }\end{array}$} \\
\hline & 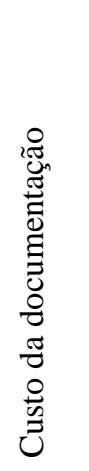 & 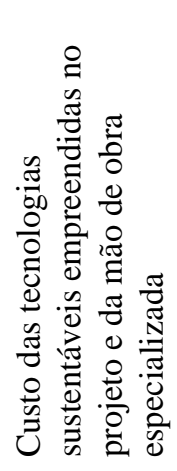 & 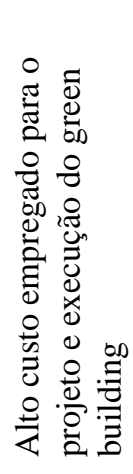 & 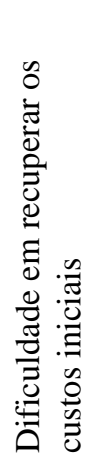 & 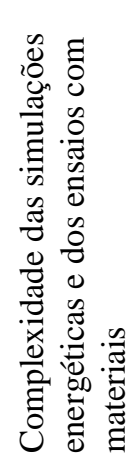 & 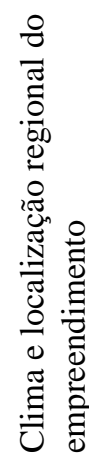 & 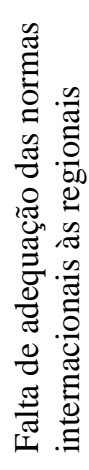 & 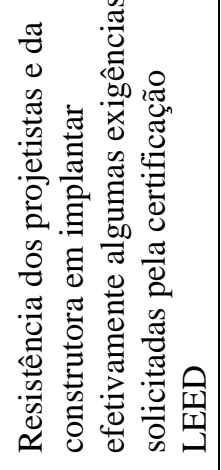 & 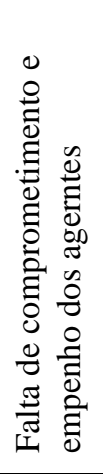 & 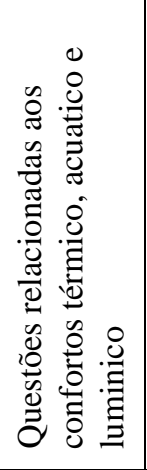 & 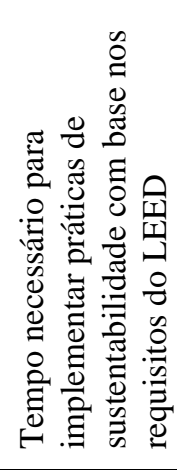 \\
\hline \multicolumn{12}{|l|}{1} \\
\hline 2 & D & D & D & D & $\mathrm{RD}$ & $\mathrm{RD}$ & D & $\mathrm{RD}$ & $\mathrm{RD}$ & $\mathrm{RD}$ & $\mathrm{RD}$ \\
\hline 3 & & & & & & $\mathrm{PD}$ & & PD & & & PD \\
\hline 4 & D & $\mathrm{D}$ & D & MD & D & $\mathrm{RD}$ & $\mathrm{MD}$ & MD & $\mathrm{RD}$ & D & D \\
\hline 5 & & MD & MD & MD & & D & & MD & & & MD \\
\hline 6 & MD & D & $\mathrm{RD}$ & D & MD & D & D & D & $\mathrm{RD}$ & $\mathrm{RD}$ & MD \\
\hline 7 & RD & D & RD & PD & $\mathrm{RD}$ & PD & RD & PD & RD & $\mathrm{RD}$ & D \\
\hline
\end{tabular}




\begin{tabular}{|c|c|c|c|c|c|}
\hline 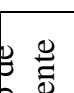 & \multicolumn{5}{|c|}{$\begin{array}{l}\text { Quais são as principais dificuldades encontradas ao longo do processo de implementação da certificação } \\
\text { LEED? }\end{array}$} \\
\hline & 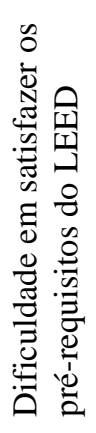 & 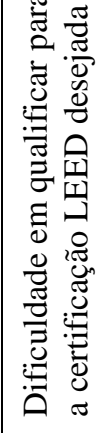 & 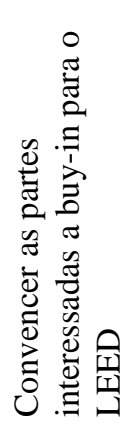 & 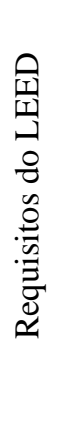 & Outras especificar \\
\hline 1 & & & & & O pioneirismo dessa certificação no Brasil \\
\hline 2 & $\mathrm{D}$ & $\mathrm{D}$ & $\mathrm{RD}$ & & Classificado de acordo com desenvolvimento do edifício \\
\hline 3 & $\mathrm{PD}$ & $\mathrm{RD}$ & & & $\begin{array}{l}\text { Não dentre dos certificados que aplicamos (core and sehell) nível } \\
\text { certificação é Prata }\end{array}$ \\
\hline 4 & $\mathrm{D}$ & $\mathrm{RD}$ & $\mathrm{D}$ & $\mathrm{D}$ & \\
\hline 5 & $\mathrm{D}$ & & & & \\
\hline 6 & $\mathrm{D}$ & $\mathrm{D}$ & $\mathrm{PD}$ & $\mathrm{D}$ & \\
\hline 7 & $\mathrm{PD}$ & $\mathrm{D}$ & PD & $\mathrm{RD}$ & \\
\hline
\end{tabular}




\begin{tabular}{|c|l|}
\hline Resposta aberta \\
\hline 1 & $\begin{array}{l}\text { Os padrôes de processos de operação e manutenção brasileiros são muito aquém dos requisitos } \\
\text { americanos. }\end{array}$ \\
\hline 2 & encontradas durante o processo de implementação da certf. LEED. \\
\hline 3 & $\begin{array}{l}\text { Ao meu ver uma grande dificuldade é o custo global para se ter a certificação LEED, pois } \\
\text { existe a empresa fiscalizadora, comissionamento, etc e esta mão de obra especializada é muito } \\
\text { cara no mercado. }\end{array}$ \\
\hline 5 & $\begin{array}{l}\text { A principal dificuldade foi demonstrar para os funcionários que sendo uma obra } \\
\text { ecologicamente correta, eles terão que agir como tal, por exemplo: não jogando bituca de } \\
\text { cigarros no chão e colocando lonas nos caminhos que saem com terras para outro pontos da } \\
\text { cidade. E o custo da obra que é vilmente mais cara do que uma obra de porte comum. }\end{array}$ \\
\hline 6 & $\begin{array}{l}\text { Há uma resistência das instaladoras em fiscalizar, documentar e executar a obra segundo as } \\
\text { exigências do LEED. As tecnologias verde ainda são caras e com retorno do investimento } \\
\text { inicial é a longo prazo. }\end{array}$ \\
\hline 7 & $\begin{array}{l}\text { Estamos tendo grande dificuldade em adotar as normas às condições regionais do } \\
\text { empreendimento entendo que muitas normas deveriam ser "tropicalizadas" muitas vezes } \\
\text { cumprimos itens da norma que não achamos que agrega muito beneficio ao empreendimento. } \\
\text { Muitas tecnologias e materiais que atendem os requisitos ainda são importados, de alto custo } \\
\text { ou não dominados pela mão de obra disponível.Quanto à aceitação dos projetistas, estamos } \\
\text { trabalhando com equipe que aceita muito bem o processo e alguns já tem experiência. Nas } \\
\text { rotinas de obra temos dificuldade em aprender o processo no inicio, mas a há grande interesse } \\
\text { de todos em realizar e os relatórios e atividades tem sido bem desempenhados. }\end{array}$ \\
\hline
\end{tabular}

\begin{tabular}{|c|c|}
\hline 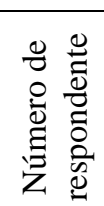 & $\begin{array}{l}\text { Qual a principal dificuldade com os projetistas, empresa fiscalizadora, profissional credenciado } \\
\text { LEED, fornecedores, construtora. }\end{array}$ \\
\hline & Resposta aberta \\
\hline 1 & Foi desenvolver fornecedores para atender a norma LEED EB. \\
\hline 2 & Implantar esses processos junto aos fornecedores. \\
\hline 3 & $\begin{array}{l}\text { Processo esta inserido dentro do processo de desenvolvimento dos projetos. Todos os } \\
\text { envolvidos tem uma vivencia de implantação do certificado. }\end{array}$ \\
\hline 4 & $\begin{array}{l}\text { A principal dificuldade é a disponibilização de projetos mais detalhados e também a } \\
\text { compreensão deste quanto a empresa fiscalizadora e consultor }\end{array}$ \\
\hline 5 & $\begin{array}{l}\text { Não encontramos nenhuma dificuldade, pois o órgão fiscalizador que contratamos esclareceu } \\
\text { todas as dúvidas necessárias. O que era pouco complicado, era seguir a risca todo os requisitos } \\
\text { para a certificação de um LEED. }\end{array}$ \\
\hline 6 & $\begin{array}{l}\text { O retorno financeiro e a dificuldade em seguir todas as exigências da certificação durante a } \\
\text { execução e compra dos insumos. }\end{array}$ \\
\hline 7 & $\begin{array}{l}\text { A principal dificuldade é o fato de ser um processo que ainda não dominamos e não temos } \\
\text { conhecimento com profundidade. Para todos ainda é um processo novo, estamos aprendendo } \\
\text { junto com a realização destes empreendimentos. A consultoria para certificação é terceirizada e } \\
\text { são profissionais que mesmo com experiência, ainda se deparam com muitas duvidas. }\end{array}$ \\
\hline
\end{tabular}




\begin{tabular}{|c|c|c|c|c|c|c|}
\hline \multirow{2}{*}{ 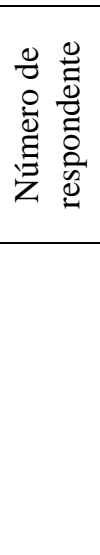 } & \multicolumn{6}{|c|}{ Na sua opinião, como poderia ser melhorado o processo de certificação? } \\
\hline & 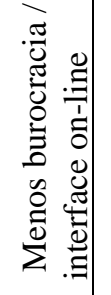 & 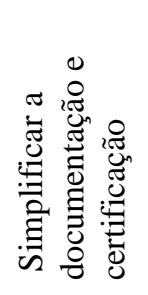 & 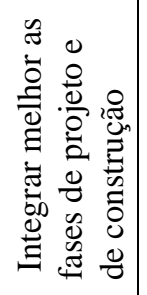 & 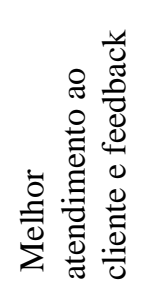 & 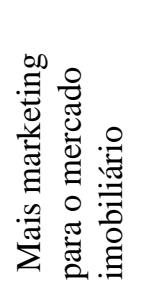 & $\stackrel{\mathscr{E}}{\tilde{\Xi}}$ \\
\hline 1 & $\mathrm{X}$ & $\mathrm{X}$ & & & & \\
\hline 2 & $\mathrm{X}$ & $\mathrm{X}$ & & $\mathrm{X}$ & & \\
\hline 3 & & $\mathrm{X}$ & & & & \\
\hline 4 & & & & & $\mathrm{X}$ & $\begin{array}{l}\text { Mais divulgação do processo, pois são } \\
\text { poucos profissionais qualificados no } \\
\text { mercado e estes coram uma fortuna. }\end{array}$ \\
\hline 5 & & & $X$ & & & \\
\hline 6 & & $\mathrm{X}$ & & & & \\
\hline 7 & $\mathrm{X}$ & & $\mathrm{X}$ & & & \\
\hline
\end{tabular}

\begin{tabular}{|c|c|c|c|c|c|c|c|c|c|}
\hline \multirow{2}{*}{ 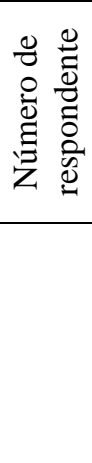 } & \multicolumn{3}{|c|}{$\begin{array}{l}\text { Em que medida a certificação LEED } \\
\text { afetou o processo de projeto, } \\
\text { execução e produto final (edifício)? }\end{array}$} & \multicolumn{6}{|c|}{$\begin{array}{l}\text { Na tabela a seguir indique: } \mathrm{O} \text { grau de dificuldade em atingir as } \\
\text { categorias exigidas pela certificação LEED. }\end{array}$} \\
\hline & $\frac{\stackrel{0}{0}}{2}$ & 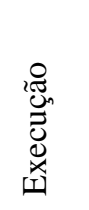 & $\begin{array}{l}\bar{\Xi} \\
\vdots \\
0 \\
0 \\
\bar{\Xi} \\
0 \\
0\end{array}$ & 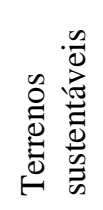 & 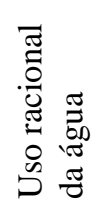 & 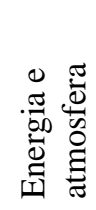 & 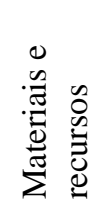 & 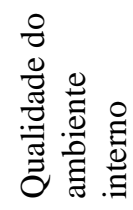 & 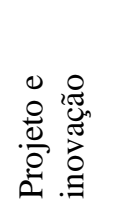 \\
\hline 1 & & & & $\mathrm{~F}$ & $\mathrm{~F}$ & ID & MD & $\mathrm{D}$ & $\mathrm{F}$ \\
\hline 2 & $\mathrm{M}$ & $\mathrm{M}$ & MM & ID & $F$ & MD & $\mathrm{D}$ & $\mathrm{D}$ & ID \\
\hline 3 & $\mathrm{M}$ & $\mathrm{M}$ & $\mathrm{M}$ & $\mathrm{D}$ & & $\mathrm{F}$ & ID & ID & $F$ \\
\hline 4 & & & & & & ID & ID & ID & \\
\hline 5 & MM & $\mathrm{P}$ & MM & $\mathrm{F}$ & $F$ & $\mathrm{~F}$ & $\mathrm{D}$ & $\mathrm{F}$ & $\mathrm{D}$ \\
\hline 6 & $M$ & $P$ & $\mathrm{M}$ & ID & ID & $F$ & $\mathrm{D}$ & ID & $\mathrm{D}$ \\
\hline 7 & MM & MM & MM & $\mathrm{F}$ & $F$ & D & D & $F$ & $F$ \\
\hline
\end{tabular}


EMPREENDEDORES DO PROCESSO AQUA

\begin{tabular}{|c|c|c|c|l|c|}
\hline $\begin{array}{c}\text { Número de } \\
\text { respondente }\end{array}$ & Nome & Telefone & Empresa & $\begin{array}{c}\text { Você é o proprietário ou investidor } \\
\text { do empreendimento? }\end{array}$ & $\begin{array}{c}\text { Empreendimento } \\
\text { e Localização }\end{array}$ \\
\hline & $\begin{array}{c}\text { Resposta } \\
\text { aberta }\end{array}$ & $\begin{array}{c}\text { Resposta } \\
\text { aberta }\end{array}$ & $\begin{array}{c}\text { Resposta } \\
\text { aberta }\end{array}$ & Resposta aberta & Resposta aberta \\
\hline 1 & XXXX & XXXX & XXXX & Empreendedor & Escola \\
\hline 2 & XXXX & XXXX & XXXX & Sim & Escola \\
\hline 3 & XXXX & XXXX & XXXX & Sim & Condomínio \\
\hline
\end{tabular}

\begin{tabular}{|c|c|c|c|c|c|c|c|}
\hline \multirow[t]{2}{*}{$\begin{array}{l}\text { Número de } \\
\text { respondente }\end{array}$} & \multicolumn{6}{|c|}{$\begin{array}{c}\text { De quem surgiu a ideia de certificar } \\
\text { com o Processo AQUA o } \\
\text { empreendimento? }\end{array}$} & $\begin{array}{l}\text { Indique o motivo mais importante para a obtenção da } \\
\text { certificação? }\end{array}$ \\
\hline & 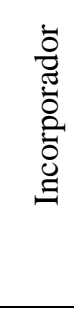 & 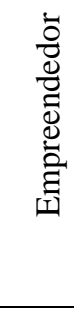 & 畩莺 & 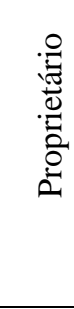 & $\begin{array}{l}\stackrel{\tilde{0}}{0} \\
\overrightarrow{0} \\
0 \\
0 \\
0\end{array}$ & Outros & \\
\hline 1 & & $\mathrm{X}$ & $\mathrm{X}$ & & $\mathrm{X}$ & & $\begin{array}{l}\text { A empresa emprega a sustentabilidade na estratégia de } \\
\text { seus negócios }\end{array}$ \\
\hline 2 & & & & $\mathrm{X}$ & & & Tomar como prioridade a construção sustentável \\
\hline 3 & $\mathrm{X}$ & & & & & & $\begin{array}{l}\text { A empresa emprega a sustentabilidade na estratégia de } \\
\text { seus negócios }\end{array}$ \\
\hline
\end{tabular}




\begin{tabular}{|c|c|c|c|c|c|c|c|c|c|c|c|c|c|c|c|c|}
\hline \multirow[t]{2}{*}{ 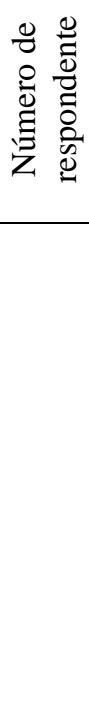 } & \multicolumn{16}{|c|}{$\begin{array}{l}\text { Entre as opções abaixo, indique (por ordem de importância) cada quesito que, em sua opinião, são os } \\
\text { principais motivos para a obtenção da certificação. }\end{array}$} \\
\hline & 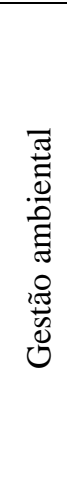 & 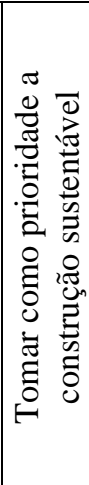 & 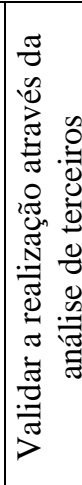 & 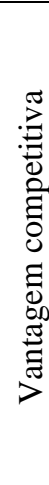 & 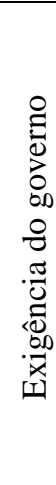 & 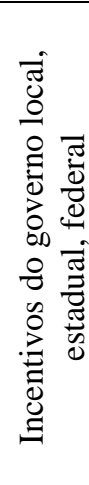 & 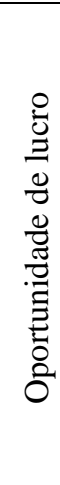 & 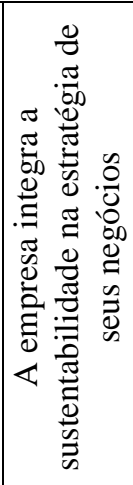 & 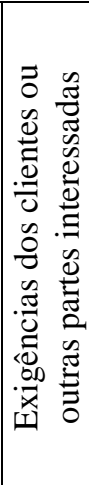 & 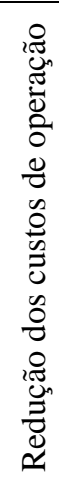 & 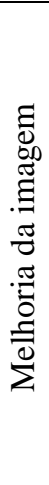 & $\begin{array}{l}0 \\
0 \\
0 \\
0 \\
0 \\
0 \\
0 \\
0 \\
0 \\
0 \\
0 \\
0 \\
0 \\
0 \\
0 \\
0\end{array}$ & 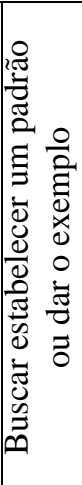 & 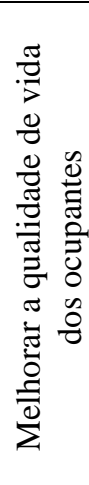 & 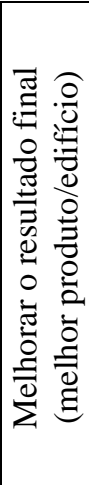 & 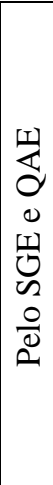 \\
\hline 1 & MI & MI & I & 1 & 1 & MI & MI & MI & MI & 1 & 1 & 1 & MI & MI & MI & I \\
\hline 2 & MI & MI & I & I & MI & MI & I & I & MI & $\mathrm{I}$ & I & I & MI & MI & I & I \\
\hline 3 & I & I & MI & MI & SI & SI & RI & MI & RI & I & I & I & I & I & MI & I \\
\hline
\end{tabular}

\begin{tabular}{|c|l|}
\hline $\begin{array}{c}\text { Número de } \\
\text { respondente }\end{array}$ & \multicolumn{1}{|c|}{ Indique o beneficio mais importante para a obtenção da certificação? } \\
\hline 1 & Redução de danos, preservação e recuperação do meio ambiente \\
\hline 2 & Redução de danos, preservação e recuperação do meio ambiente \\
\hline 3 & Mais produtividade, conforto e saúde do usuário \\
\hline
\end{tabular}




\begin{tabular}{|c|c|c|c|c|c|c|c|c|c|c|c|c|c|c|}
\hline \multirow{2}{*}{ 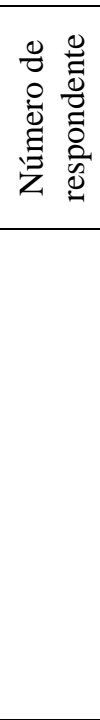 } & \multicolumn{14}{|c|}{$\begin{array}{l}\text { Quais são os benefícios principais da implementação do Processo AQUA para este } \\
\text { empreendimento? }\end{array}$} \\
\hline & 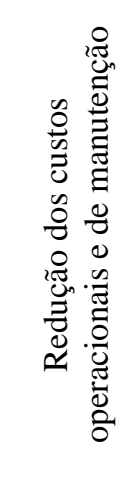 & $\begin{array}{l}0 \\
0 \\
0 \\
0 \\
0 \\
0 \\
0 \\
0 \\
0 \\
0 \\
0 \\
0 \\
0 \\
0 \\
0 \\
\infty\end{array}$ & 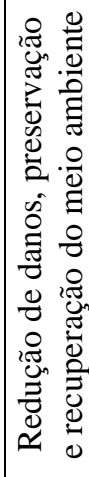 & 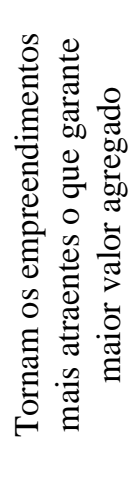 & 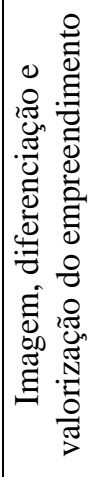 & 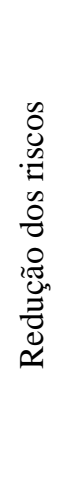 & 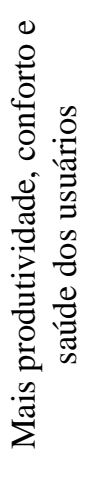 & 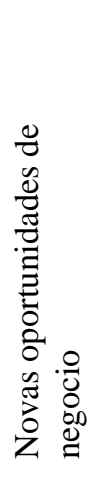 & 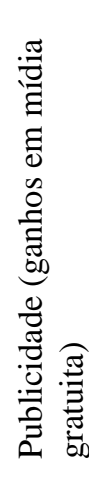 & 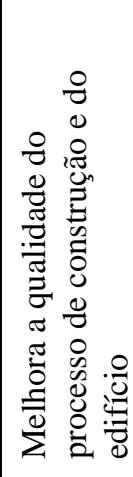 & 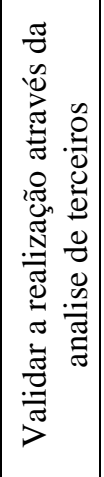 & 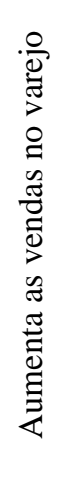 & 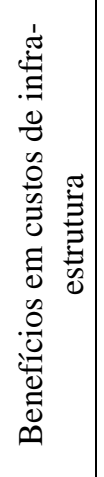 & 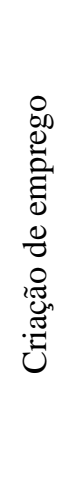 \\
\hline 1 & MI & MI & MI & I & I & I & I & I & I & I & I & & & \\
\hline 2 & I & I & MI & I & MI & $\mathrm{I}$ & MI & RI & I & I & I & $\mathrm{RI}$ & I & $\mathrm{I}$ \\
\hline 3 & MI & I & MI & RI & I & RI & MI & MI & $\mathrm{I}$ & $\mathrm{I}$ & MI & RI & PI & PI \\
\hline
\end{tabular}

\begin{tabular}{|c|c|c|c|}
\hline 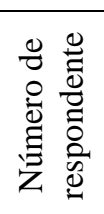 & $\begin{array}{l}\text { Quais foram as dificuldades } \\
\text { enfrentadas por você ao } \\
\text { implementar o SGE e na } \\
\text { avaliação da QAE? }\end{array}$ & $\begin{array}{l}\text { Quais foram os pontos críticos } \\
\text { e de sucesso para a gestão do } \\
\text { processo de projeto? }\end{array}$ & $\begin{array}{l}\text { Quanto foi o custo adicional } \\
\text { em relação a uma edificação } \\
\text { convencional (custos do } \\
\text { projeto, construção e } \\
\text { operação)? }\end{array}$ \\
\hline & Resposta aberta & Resposta aberta & Resposta aberta \\
\hline \multicolumn{4}{|c|}{ Kesposta auerta } \\
\hline 2 & $\begin{array}{l}\text { Não houve dificuldades já que } \\
\text { estávamos bem assessorados e } \\
\text { toda a equipe de projeto } \\
\text { entusiasmada com a } \\
\text { certificação. }\end{array}$ & $\begin{array}{l}\text { A análise criteriosa de todas as } \\
\text { tomadas de decisão. }\end{array}$ & $\begin{array}{l}\text { Creio que há um custo } \\
\text { adicional, mas não tive essa } \\
\text { informação disponível pela } \\
\text { FDE }\end{array}$ \\
\hline 3 & & & $4 \%$ a mais de custo na obra \\
\hline
\end{tabular}




\begin{tabular}{|c|c|c|c|c|c|c|c|c|c|c|c|c|}
\hline 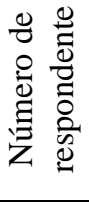 & \multicolumn{12}{|c|}{ Quais as dificuldades encontradas ao longo do processo de implementação do Processo AQUA? } \\
\hline & 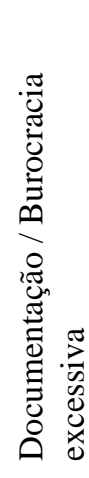 & 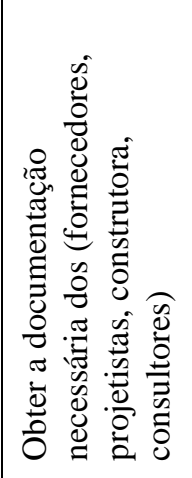 & 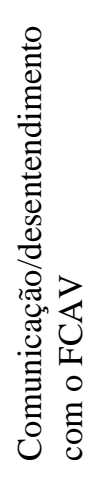 & 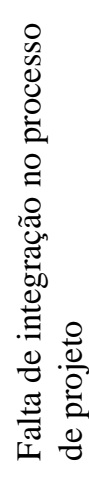 & 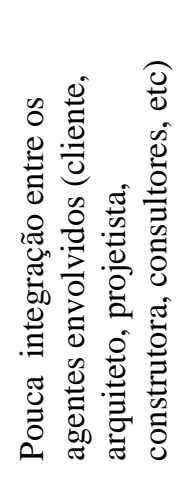 & 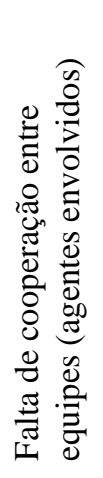 & 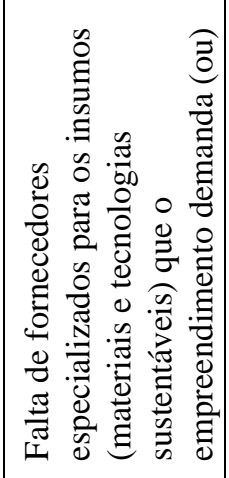 & 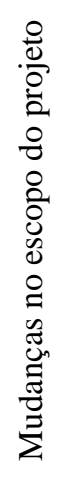 & 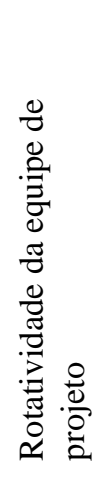 & 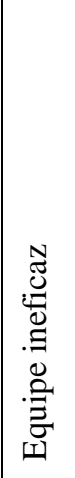 & 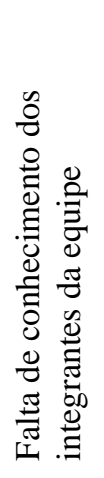 & 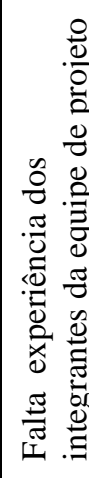 \\
\hline 1 & $\mathrm{D}$ & $\mathrm{D}$ & $\mathrm{D}$ & $\mathrm{RD}$ & $\mathrm{RD}$ & $\mathrm{D}$ & $\mathrm{D}$ & $\mathrm{RD}$ & $\mathrm{D}$ & $\mathrm{D}$ & $\mathrm{D}$ & $\mathrm{D}$ \\
\hline 2 & SD & SD & $\mathrm{PD}$ & SD & SD & SD & $\mathrm{RD}$ & PD & SD & SD & SD & $\mathrm{PD}$ \\
\hline 3 & $\mathrm{RD}$ & $\mathrm{D}$ & $\mathrm{RD}$ & $\mathrm{RD}$ & $\mathrm{RD}$ & $\mathrm{RD}$ & $\mathrm{D}$ & $\mathrm{RD}$ & $\mathrm{PD}$ & PD & $\mathrm{RD}$ & $\mathrm{RD}$ \\
\hline
\end{tabular}

\begin{tabular}{|c|c|c|c|c|c|c|c|c|c|c|c|}
\hline \multirow[t]{2}{*}{ 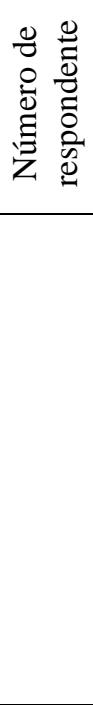 } & \multicolumn{11}{|c|}{ Quais as dificuldades encontradas ao longo do processo de implementação do Processo AQUA? } \\
\hline & 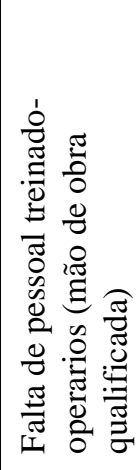 & 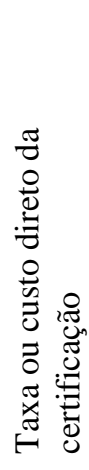 & 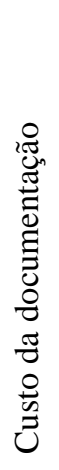 & 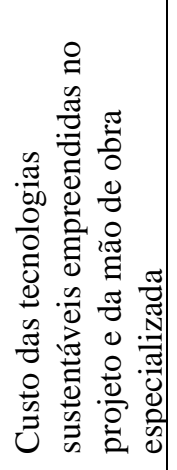 & 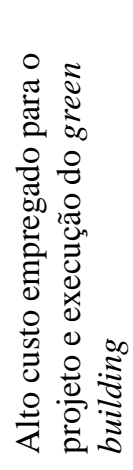 & 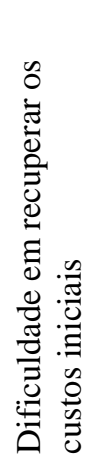 & 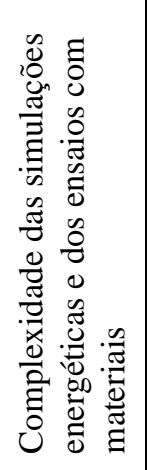 & 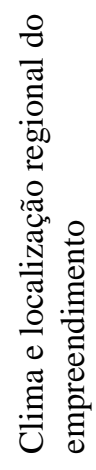 & 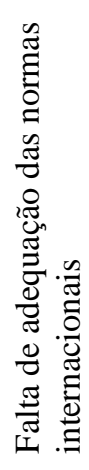 & 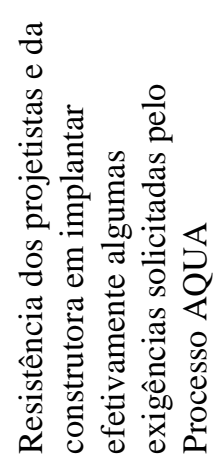 & 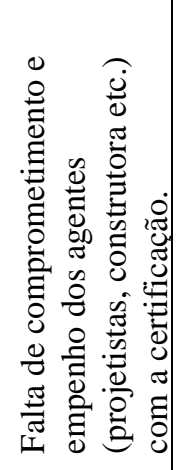 \\
\hline 1 & $\mathrm{D}$ & $\mathrm{RD}$ & $\mathrm{RD}$ & $\mathrm{D}$ & $\mathrm{D}$ & $\mathrm{D}$ & $\mathrm{D}$ & $\mathrm{D}$ & $\mathrm{D}$ & $\mathrm{D}$ & $\mathrm{RD}$ \\
\hline 2 & & SD & $\mathrm{RD}$ & PD & SD & PD & PD & PD & SD & PD & SD \\
\hline 3 & RD & RD & SD & $\mathrm{D}$ & $\mathrm{RD}$ & MD & $\mathrm{RD}$ & $\mathrm{RD}$ & PD & PD & $\mathrm{PD}$ \\
\hline
\end{tabular}




\begin{tabular}{|c|c|c|c|c|c|c|}
\hline \multirow[t]{2}{*}{ 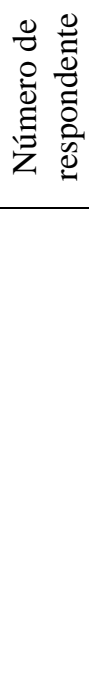 } & \multicolumn{6}{|c|}{ Quais as dificuldades encontradas ao longo do processo de implementação do Processo AQUA? } \\
\hline & 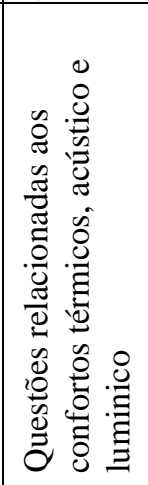 & 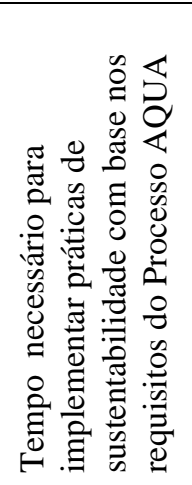 & 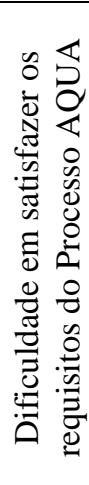 & 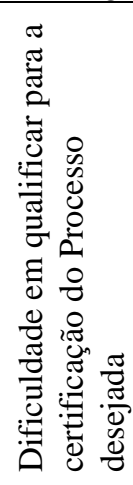 & 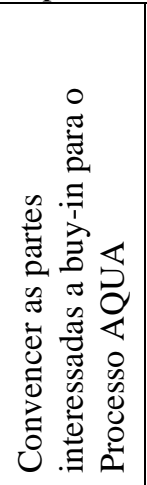 & $\begin{array}{l}\text { Você, pôde comentar livremente as } \\
\text { dificuldades mencionadas e mencionar } \\
\text { outras dificuldades encontradas durante o } \\
\text { processo de implementação do Processo } \\
\text { AQUA. }\end{array}$ \\
\hline 1 & $\mathrm{RD}$ & $\mathrm{D}$ & $\mathrm{D}$ & $\mathrm{D}$ & $\mathrm{D}$ & Resposta aberta \\
\hline 2 & SD & PD & PD & PD & & $\begin{array}{l}\text { A obra ainda não iniciou, portanto os } \\
\text { requisitos referentes à obra serão } \\
\text { enfrentadas nos próximos meses. }\end{array}$ \\
\hline 3 & MD & $\mathrm{RD}$ & RD & $\mathrm{RD}$ & MD & \\
\hline
\end{tabular}

\begin{tabular}{|c|l|}
\hline $\begin{array}{c}\text { Número de } \\
\text { respondente }\end{array}$ & \multicolumn{1}{|c|}{ Indique a dificuldade mais difícil para a obter a certificação? } \\
\hline & \\
\hline 1 & $\begin{array}{l}\text { Falta de fornecedores especializados para os insumos (materiais e tecnologias } \\
\text { sustentáveis) que o empreendimento demanda ou demandou }\end{array}$ \\
\hline 2 & $\begin{array}{l}\text { Falta de fornecedores especializados para os insumos (materiais e tecnologias } \\
\text { sustentáveis) que o empreendimento demanda ou demandou }\end{array}$ \\
\hline 3 & Convencer as partes interessadas a buy-in (pagar) para o Processo AQUA \\
\hline
\end{tabular}




\begin{tabular}{|c|c|c|c|c|c|c|c|c|}
\hline \multirow{2}{*}{ 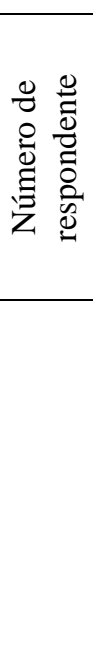 } & $\begin{array}{l}\text { Qual a principal dificuldade com os } \\
\text { projetistas, empresa fiscalizadora, consultor, } \\
\text { fornecedores, construtora }\end{array}$ & \multicolumn{7}{|c|}{$\begin{array}{l}\text { Quem ficou responsável do fluxo de informações } \\
\text { entre projetistas especialistas e empreendedor e } \\
\text { de estruturar os documentos exigidas pelo } \\
\text { processo de certificação AQUA? }\end{array}$} \\
\hline & Resposta aberta & 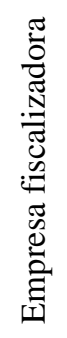 & $\frac{0}{\stackrel{0}{\Xi}}$ & $\begin{array}{l}\frac{\pi}{0} \\
\stackrel{0}{0} \\
0 \\
0 \\
0\end{array}$ & 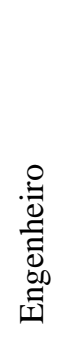 & 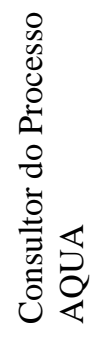 & 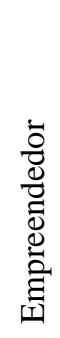 & 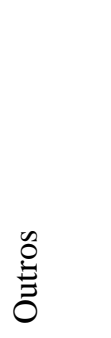 \\
\hline 1 & $\begin{array}{l}\text { Integração de todas as disciplinas de projeto e } \\
\text { apresentação de memoriais de cálculo } \\
\text { adequados aos requisitos da norma. }\end{array}$ & & & & & $\mathrm{X}$ & & \\
\hline 2 & $\begin{array}{l}\text { Não houve até o momento qualquer } \\
\text { dificuldade que merecesse destaque. }\end{array}$ & & & & & $\mathrm{X}$ & & \\
\hline 3 & & & & & & & $\mathrm{X}$ & \\
\hline
\end{tabular}

\begin{tabular}{|c|c|c|c|c|c|c|c|c|}
\hline \multirow{2}{*}{ 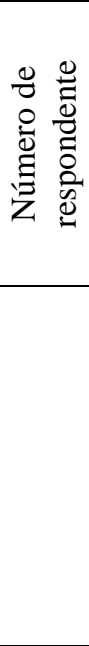 } & \multicolumn{7}{|c|}{$\begin{array}{l}\text { Quais das partes contratadas têm profissionais } \\
\text { com conhecimento sobre o processo de } \\
\text { certificação AQUA? }\end{array}$} & \multirow{2}{*}{$\begin{array}{l}\text { Quais são as maiores dificuldades em relação à } \\
\text { documentação exigida pelo Processo } \\
\text { AQUA?Documento de comprometimento,perfil } \\
\text { de qualidade ambiental,contratos, documentos } \\
\text { gestão, documentos empreendimento, } \\
\text { declarações de legalidade trabalhista }\end{array}$} \\
\hline & 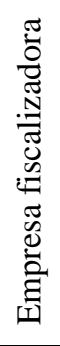 & 兽 & 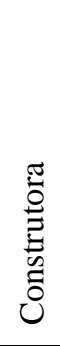 & 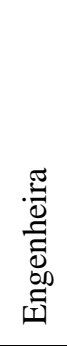 & 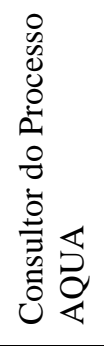 & 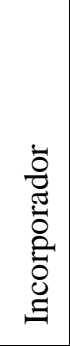 & 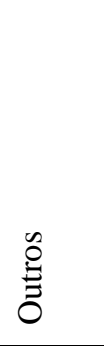 & \\
\hline 1 & & & & & X & $X$ & & $\begin{array}{l}\text { Depende de cada empreendedor, quanto mais } \\
\text { comprometido o empreendedor, menores as } \\
\text { dificuldades de se obter documentação. }\end{array}$ \\
\hline 2 & $X$ & $X$ & & $X$ & $X$ & $X$ & & $\begin{array}{l}\text { A obra ainda não iniciou, portanto os requisitos } \\
\text { referentes à obra serão enfrentados nos próximos } \\
\text { meses. }\end{array}$ \\
\hline 3 & & & $X$ & & & $X$ & & \\
\hline
\end{tabular}




\begin{tabular}{|c|c|c|c|c|c|c|c|c|}
\hline \multirow{2}{*}{ 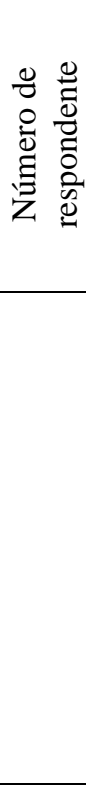 } & $\begin{array}{c}\text { Quais são os } \\
\text { entraves ou } \\
\text { barreiras internas e } \\
\text { externas para a } \\
\text { implementação do } \\
\text { Processo AQUA? }\end{array}$ & \multirow{2}{*}{$\begin{array}{l}\text { Como poderia ter } \\
\text { sido implantado o } \\
\text { Processo AQUA de } \\
\text { maneira mais eficaz } \\
\text { antes e durante a } \\
\quad \text { construção }\end{array}$} & \multicolumn{6}{|c|}{$\begin{array}{l}\text { Na sua opinião, como poderia ser melhorado o processo de } \\
\text { certificação? }\end{array}$} \\
\hline & Resposta aberta & & 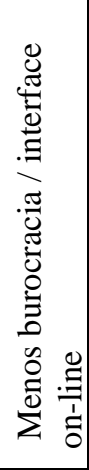 & 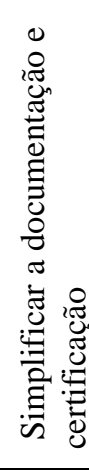 & 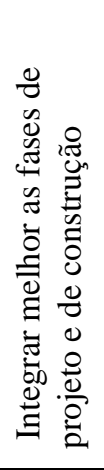 & 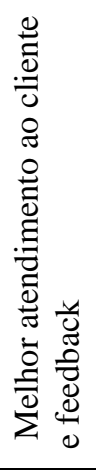 & 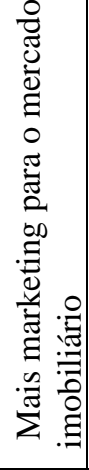 & $\stackrel{\mathscr{E}}{0}$ \\
\hline 1 & $\begin{array}{l}\text { Linhas de credito } \\
\text { do governo } \\
\text { especificas para a } \\
\text { sustentabilidade, } \\
\text { comprometimento } \\
\text { de todos os } \\
\text { envolvidos na } \\
\text { cadeia produtiva. }\end{array}$ & $\begin{array}{l}\text { Com a tomada de } \\
\text { decisão em } \\
\text { momentos mais } \\
\text { preliminares do } \\
\text { projeto }\end{array}$ & & & & & & $\begin{array}{l}\text { O processo de } \\
\text { certificação é o } \\
\text { mais adequado ao } \\
\text { Brasil, porém ainda } \\
\text { possui alguns } \\
\text { requisitos que } \\
\text { demandam } \\
\text { evolução do } \\
\text { mercado para } \\
\text { serem atendidos. }\end{array}$ \\
\hline 2 & $\begin{array}{l}\text { Até o momento não } \\
\text { identifiquei } \\
\text { qualquer entrave. }\end{array}$ & $\begin{array}{c}\text { Infelizmente a } \\
\text { decisão pela XX } \\
\text { pela certificação foi } \\
\text { feita quando o } \\
\text { projeto estava em } \\
\text { sua fase final de } \\
\text { elaboração } \\
\end{array}$ & & & $\mathrm{X}$ & & & \\
\hline 3 & & & & & & & & \\
\hline
\end{tabular}




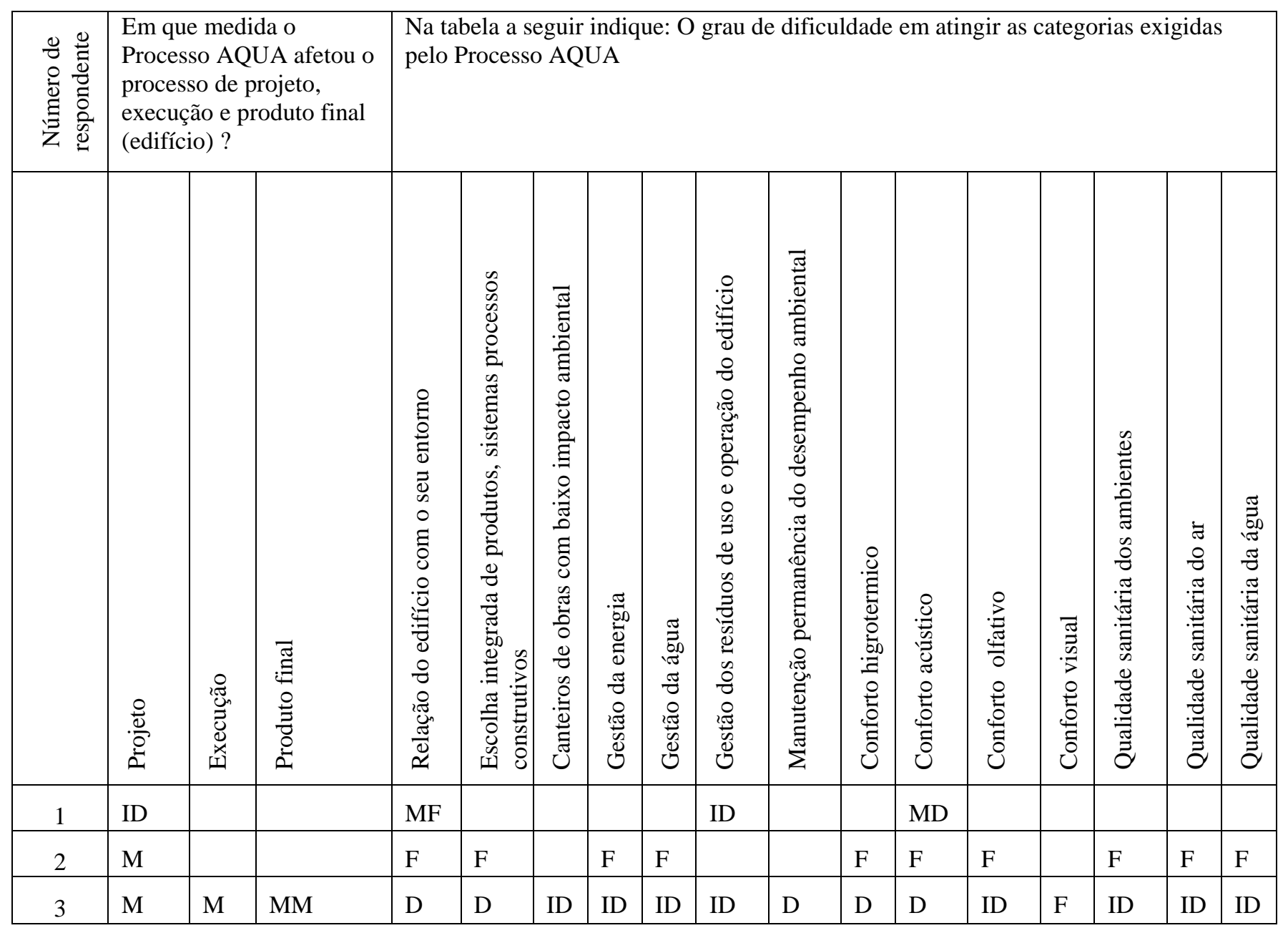




\begin{tabular}{|c|c|c|c|c|c|c|c|c|c|c|c|c|c|c|}
\hline \multirow{2}{*}{ 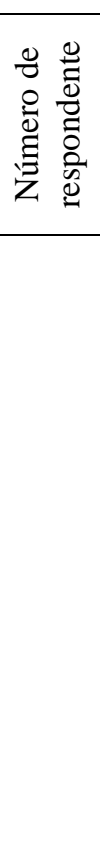 } & \multicolumn{14}{|c|}{ Na tabela a seguir indique: O grau de importância de cada uma as categorias consideradas no projeto } \\
\hline & 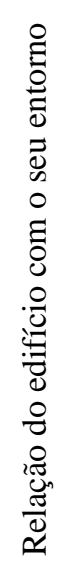 & 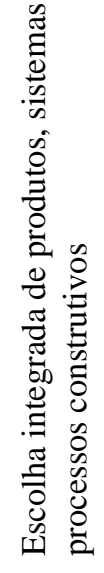 & 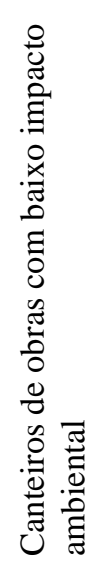 & 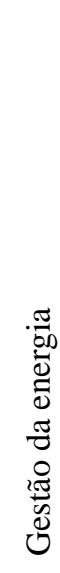 & 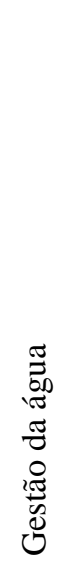 & 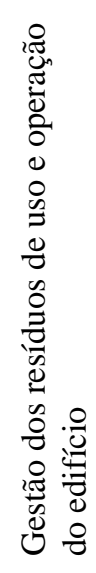 & 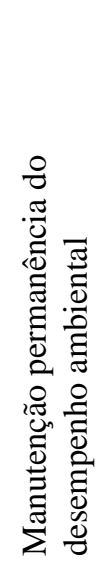 & 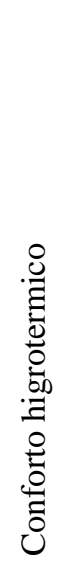 & 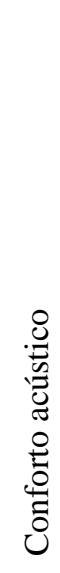 & 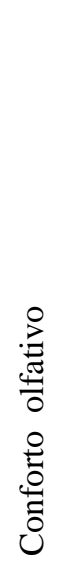 & $\begin{array}{l}\bar{\Xi} \\
\tilde{0} \\
5 \\
0 \\
0 \\
0 \\
0 \\
0\end{array}$ & 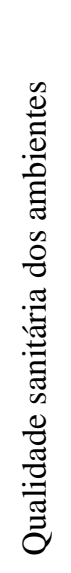 & 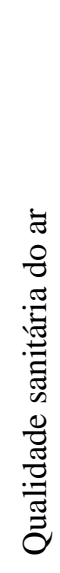 & 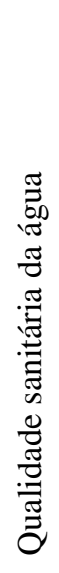 \\
\hline 1 & MI & MI & MI & MI & MI & MI & MI & MI & MI & MI & MI & MI & MI & MI \\
\hline 2 & MI & MI & MI & MI & MI & MI & MI & MI & MI & MI & MI & MI & MI & MI \\
\hline 3 & I & I & I & MI & MI & I & MI & I & ID & ID & I & I & ID & I \\
\hline
\end{tabular}

\begin{tabular}{|c|c|c|c|c|c|c|c|c|c|c|c|c|c|c|}
\hline \multirow{2}{*}{ 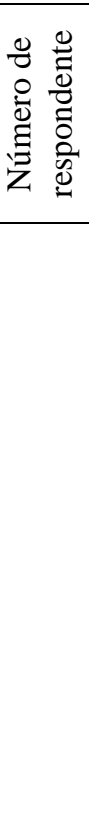 } & \multicolumn{14}{|c|}{ Na tabela a seguir indique: As categorias que demandaram maior ciudado durante o projeto e a obra } \\
\hline & 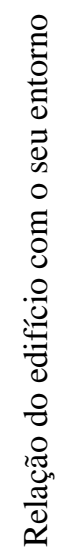 & 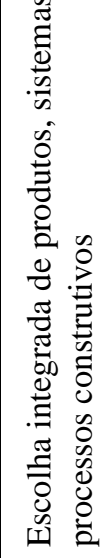 & 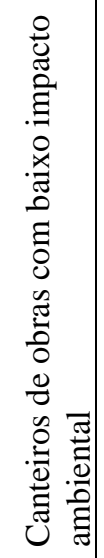 & 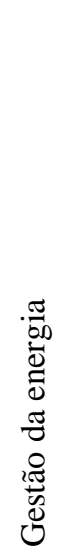 & 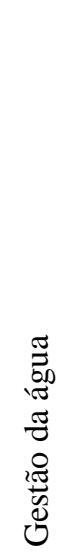 & 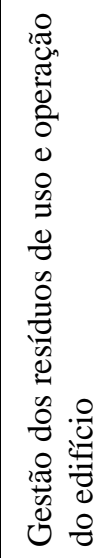 & 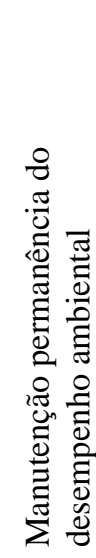 & 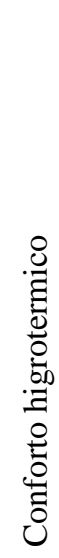 & 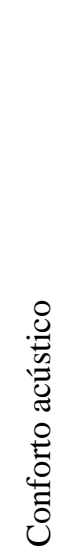 & 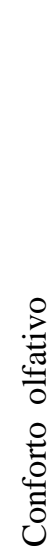 & $\begin{array}{l}\overline{3} \\
\overline{3} \\
\frac{3}{7} \\
0 \\
0 \\
0 \\
0 \\
0 \\
0\end{array}$ & 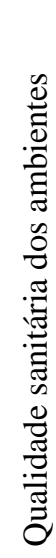 & 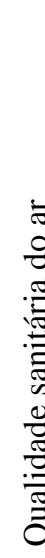 & 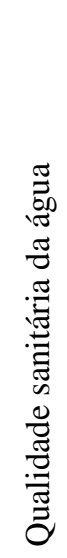 \\
\hline 1 & NA & NA & NA & NA & NA & NA & NA & NA & NA & $\mathrm{N} A$ & NA & NA & $\mathrm{N}$ & NA \\
\hline \multicolumn{15}{|l|}{2} \\
\hline 3 & ID & ID & ID & ID & ID & ID & ID & ID & ID & ID & ID & ID & ID & ID \\
\hline
\end{tabular}


PROFISSIONAL CREDENCIADO LEED

\begin{tabular}{|c|c|c|c|c|}
\hline $\begin{array}{l}\text { Número de } \\
\text { respondente }\end{array}$ & Nome & Telefone & Empresa & Qual é o uso do empreendimento? \\
\hline & $\begin{array}{c}\text { Resposta } \\
\text { aberta }\end{array}$ & $\begin{array}{c}\text { Resposta } \\
\text { aberta }\end{array}$ & $\begin{array}{c}\text { Resposta } \\
\text { aberta }\end{array}$ & \\
\hline 1 & XXXX & XXXX & XXXX & Fàbrica \\
\hline 2 & $\mathrm{XXXX}$ & XXXX & XXXX & Centro cultural \\
\hline 3 & XXXX & XXXX & XXXX & Vários \\
\hline 4 & XXXX & XXXX & XXXX & Escritorio \\
\hline 5 & XXXX & XXXX & XXXX & \\
\hline 6 & $\mathrm{XXXX}$ & XXXX & $\mathrm{XXXX}$ & Vários \\
\hline 7 & XXXX & XXXX & XXXX & \\
\hline 8 & XXXX & XXXX & XXXX & Hospital \\
\hline
\end{tabular}

\begin{tabular}{|c|c|c|c|c|}
\hline 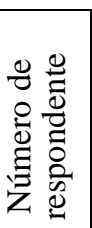 & Função e cargo & $\begin{array}{l}\text { Você é um } \\
\text { Professional } \\
\text { credenciado } \\
\text { LEED?Se a } \\
\text { resposta for sim, há } \\
\text { quanto tempo? }\end{array}$ & $\begin{array}{l}\text { Quantos anos de } \\
\text { experiência você tem, em } \\
\text { construção de edifícios? }\end{array}$ & $\begin{array}{l}\text { Em quantos } \\
\text { empreendimentos } \\
\text { certificados, você já } \\
\text { participou? }\end{array}$ \\
\hline & Resposta aberta & Resposta aberta & Resposta aberta & Resposta aberta \\
\hline 1 & Arquiteto e consultor & Sim, há 2 anos & + de 20 & 1 \\
\hline 2 & Diretor & $\begin{array}{l}\text { Meu sócio era, há } \\
\text { muitos anos atrás }\end{array}$ & 30 anos & 1 \\
\hline 3 & $\begin{array}{l}\text { Arquiteto LEED-AP } \\
\text { Coordenador }\end{array}$ & Desde Junho 2009 & Aprox. 8 anos & $\begin{array}{l}\text { Aprox. } 20 \text { em processo } \\
\text { de certificação, sendo } 6 \\
\text { já certificados }\end{array}$ \\
\hline 4 & $\begin{array}{l}\text { Arquiteta professora } \\
\text { Universitária }\end{array}$ & Sim, há 3 anos & & 1 \\
\hline 5 & Diretor & Sim, 03 anos & 32 anos & 10 \\
\hline 6 & Engenheiro & LEED AP há 1 ano & 1 ano & 3 \\
\hline 7 & Researcher & Sim, Janeiro 2007 & 25 & 3 \\
\hline 8 & Diretor de projetos & Sim, desde 2007 & 11 anos & 4 \\
\hline
\end{tabular}




\begin{tabular}{|c|c|c|c|c|c|c|c|c|c|c|}
\hline \multirow[t]{2}{*}{ 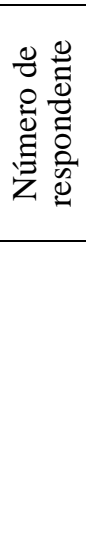 } & $\begin{array}{l}\text { Concluiu o } \\
\text { processo de } \\
\text { certificação? }\end{array}$ & $\begin{array}{c}\text { Qual é o nível } \\
\text { de certificação } \\
\text { do } \\
\text { empreendimen } \\
\text { to? }\end{array}$ & $\begin{array}{l}\text { Qual dos } \\
\text { LEED se } \\
\text { escolheu } \\
\text { para este } \\
\text { empreendim } \\
\text { ento? }\end{array}$ & \multicolumn{7}{|c|}{$\begin{array}{l}\text { De quem surgiu a idéia de certificar com o LEED o } \\
\text { empreendimento? }\end{array}$} \\
\hline & Resposta fechada & $\begin{array}{l}\text { Resposta } \\
\text { fechada }\end{array}$ & & 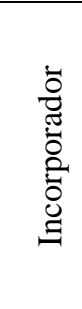 & & 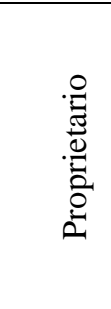 & 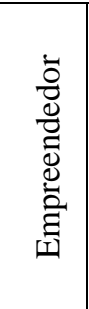 & 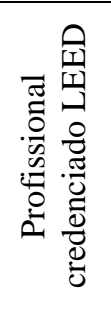 & 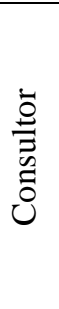 & $\begin{array}{l}\stackrel{n}{0} \\
\stackrel{\Xi}{0}\end{array}$ \\
\hline 1 & $\begin{array}{l}\text { Não porque os } \\
\text { envolvidos, } \\
\text { incluindo } \\
\text { proprietário, não } \\
\text { entenderam a lógica } \\
\text { do processo, sem } \\
\text { nos consultar, } \\
\text { tomaram decisões } \\
\text { que inviabilizaram } \\
\text { a certificação. }\end{array}$ & Certificado & & & $\mathrm{X}$ & & & & & Cliente \\
\hline 2 & Sim & Ouro & & & & & & & & Cliente \\
\hline 3 & & Prata & & & & $\mathrm{X}$ & & & & \\
\hline 4 & $\begin{array}{l}\text { Não. Houve } \\
\text { interesse em } \\
\text { conhecer o processo } \\
\text { e implementar a } \\
\text { metodologia de } \\
\text { certificação, mas } \\
\text { não em certificar o } \\
\text { edifício }\end{array}$ & Prata & & & & & & & & Cliente \\
\hline 5 & $\begin{array}{l}\text { Participei com } \\
\text { pequenos palpites }\end{array}$ & & & & & & $\mathrm{X}$ & & & Cliente \\
\hline 6 & Em andamento & Prata & LEED CS & $\mathrm{X}$ & & & & & & Cliente \\
\hline 7 & $\begin{array}{l}\text { Sim, uma das } \\
\text { diretrizes do projeto } \\
\text { era a certificação } \\
\text { LEED }\end{array}$ & Certificado & LEED NC & & & & & & & $\begin{array}{l}\text { Empresa } \\
\text { locatária }\end{array}$ \\
\hline 8 & Sim & Ouro & LEED NC & & $\mathrm{X}$ & & & & & \\
\hline
\end{tabular}




\begin{tabular}{|c|l|}
\hline $\begin{array}{c}\text { Número de } \\
\text { respondente }\end{array}$ & Indique o motivo mais importante para a obtenção da certificação? \\
\hline 1 & Melhorar o resultado final (melhor produto/edifício) \\
\hline 2 & Melhorar a qualidade de vida de seus ocupantes \\
\hline 3 & Exigências dos clientes e outras partes interessadas \\
\hline 4 & Melhoria da imagem \\
\hline 5 & Oportunidades de lucro \\
\hline 6 & Tomar como prioridade a construção sustentável \\
\hline 7 & \\
\hline 8 & Tomar como prioridade a construção sustentável \\
\hline
\end{tabular}

\begin{tabular}{|c|c|c|c|c|c|}
\hline \multirow{2}{*}{$\begin{array}{l}\text { Número de } \\
\text { respondente }\end{array}$} & \multicolumn{5}{|c|}{$\begin{array}{l}\text { Entre as opções abaixo, indique (por ordem de importância) cada quesito que, em sua } \\
\text { opinião, são os principais motivos para a obtenção da certificação da certificação LEED para } \\
\text { este empreendimento: }\end{array}$} \\
\hline & 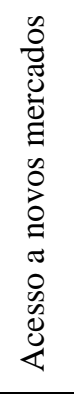 & 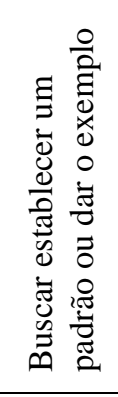 & 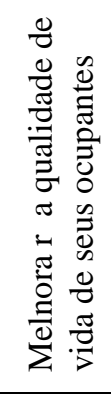 & 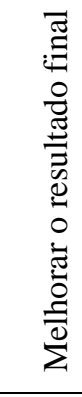 & Outras \\
\hline 1 & MI & MI & MI & MI & \\
\hline 2 & I & I & MI & I & \\
\hline 3 & PI & PI & PI & RI & \\
\hline 4 & MI & MI & I & RI & $\begin{array}{l}\text { Obs. Respondi pelo que vejo em relação aos que me } \\
\text { procuram solicitando informações, não reflete o que eu, } \\
\text { pessoalmente, penso Minhas respostas refletem o que } \\
\text { percebi sobre o contratante, não refletem minhas opiniões } \\
\text { sobre o assunto. }\end{array}$ \\
\hline 5 & RI & PI & SI & SI & \\
\hline 6 & I & $\mathrm{RI}$ & MI & MI & \\
\hline 7 & & & & & \\
\hline 8 & I & I & MI & MI & \\
\hline
\end{tabular}




\begin{tabular}{|c|l|}
\hline $\begin{array}{c}\text { Número de } \\
\text { respondente }\end{array}$ & Indique o beneficio mais importante para a obtenção da certificação? \\
\hline 1 & Melhora a qualidade do processo de construção e de seus produtos (empreendimento) \\
\hline 2 & Mais produtividade, conforto e saúde do usuário \\
\hline 3 & Tornam os empreendimentos mais atraentes o que garante um maior valor agregado \\
\hline 4 & Publicidade (ganhos em mídia gratuita \\
\hline 5 & Imagem, diferenciação e valorização do empreendimento \\
\hline 6 & \\
\hline 7 & \\
\hline 8 & Melhora a qualidade do processo de construção e de seus produtos (empreendimento) \\
\hline
\end{tabular}

\begin{tabular}{|c|c|c|c|c|c|c|c|c|c|c|}
\hline \multirow{2}{*}{$\begin{array}{l}\text { Número de } \\
\text { respondente }\end{array}$} & \multicolumn{10}{|c|}{ Quais são os benefícios que recebe ou pretende receber, para este empreendimento? } \\
\hline & 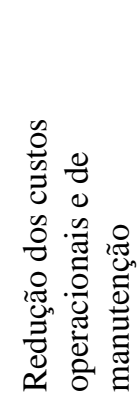 & 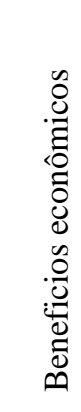 & 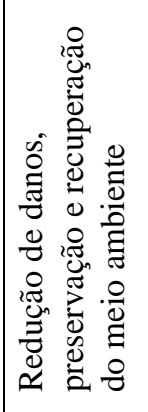 & 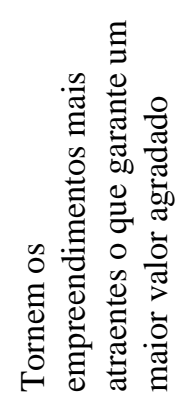 & 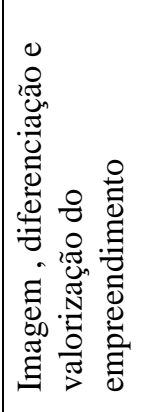 & 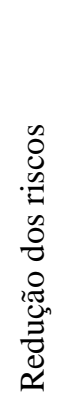 & 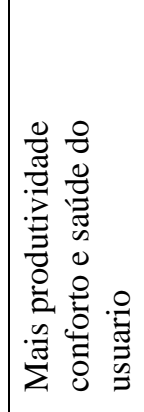 & 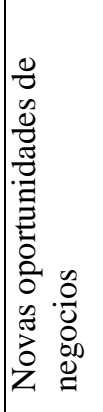 & 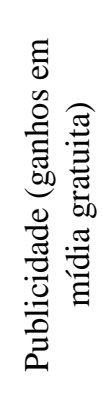 & 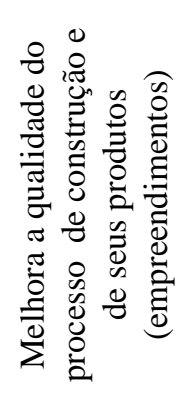 \\
\hline 1 & MI & MI & MI & MI & MI & I & MI & MI & MI & MI \\
\hline 2 & RI & RI & $\mathrm{I}$ & RI & RI & I & MI & RI & RI & I \\
\hline 3 & I & $\mathrm{I}$ & RI & I & I & $\mathrm{RI}$ & RI & RI & RI & RI \\
\hline \multicolumn{11}{|l|}{4} \\
\hline \multicolumn{11}{|l|}{5} \\
\hline 6 & I & I & MI & MI & MI & PI & MI & I & MI & RI \\
\hline \multicolumn{11}{|l|}{7} \\
\hline 8 & MI & I & I & MI & MI & I & I & I & I & MI \\
\hline
\end{tabular}




\begin{tabular}{|c|c|c|c|c|c|c|c|c|c|c|}
\hline \multirow{2}{*}{$\begin{array}{c}\text { Número } \\
\text { de } \\
\text { respondent } \\
\mathrm{e} \\
\end{array}$} & \multicolumn{5}{|c|}{$\begin{array}{l}\text { Quais são os benefícios que recebe ou pretende } \\
\text { receber, para este empreendimento? }\end{array}$} & \multicolumn{5}{|c|}{$\begin{array}{l}\text { Em que fase se decidiu pela certificação } \\
\text { LEED? }\end{array}$} \\
\hline & 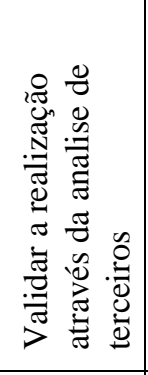 & 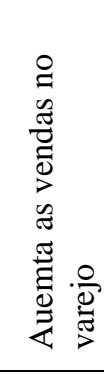 & 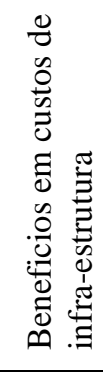 & 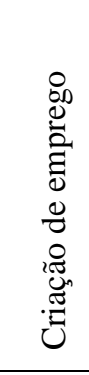 & Outras & 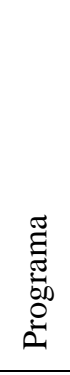 & 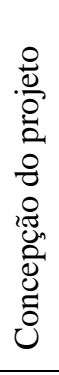 & 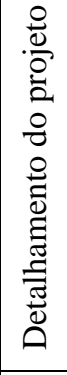 & 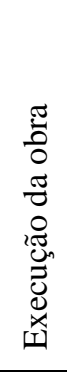 & $\stackrel{\mathscr{E}}{\tilde{0}}$ \\
\hline 1 & MI & I & MI & MI & & & $X$ & & & \\
\hline 2 & RI & RI & RI & RI & & & $\mathrm{X}$ & & & \\
\hline 3 & I & RI & PI & PI & & & $X$ & & & \\
\hline 4 & & & & & $\begin{array}{l}\text { Não respondi em } \\
\text { ordem de } \\
\text { importancia, } \\
\text { considero todos } \\
\text { estes aspectos } \\
\text { válidos. }\end{array}$ & & & & & $\begin{array}{l}\text { O detalhamento } \\
\text { do projeto e a } \\
\text { obra ocorreram } \\
\text { simultaneamente. }\end{array}$ \\
\hline 5 & & & & & & & $\mathrm{X}$ & & & \\
\hline 6 & I & MI & PI & RI & & & $X$ & & & \\
\hline 7 & & & & & & & $\mathrm{X}$ & & & \\
\hline 8 & RI & RI & I & RI & $\begin{array}{l}\text { Melhorar a } \\
\text { integração entre } \\
\text { disciplinas } \\
\text { projetuais- } \\
\text { arquitetura e } \\
\text { engenharias- e } \\
\text { valorização dos } \\
\text { efeitos das } \\
\text { decisões } \\
\text { projetuais na obra } \\
\text { e operação do } \\
\text { edificio }\end{array}$ & $X$ & & & & \\
\hline
\end{tabular}




\begin{tabular}{|c|c|c|c|c|c|c|c|c|}
\hline \multirow[t]{2}{*}{$\begin{array}{l}\text { Número de } \\
\text { respondente }\end{array}$} & $\begin{array}{l}\text { Quanto foi o custo } \\
\text { adicional (\% ou R\$) } \\
\text { associado à } \\
\text { implementação da } \\
\text { certificação LEED no: } \\
\text { projeto, consultoria, } \\
\text { execução, certificação, } \\
\text { consultoria, materiais, } \\
\text { ensaios, operação, outros } \\
\text { comentar }\end{array}$ & $\begin{array}{l}\text { Quanto foi o custo adicional } \\
\text { em relação a uma edificação } \\
\text { convencional (custos do } \\
\text { projeto, construção e } \\
\text { operação)?\% ou R\$ }\end{array}$ & \multicolumn{6}{|c|}{$\begin{array}{l}\text { Da lista a seguir, selecione os } \\
\text { que trabalharam com o LEED } \\
\text { antes de seu envolvimento com } \\
\text { o projeto LEED registrado }\end{array}$} \\
\hline & Resposta aberta & Resposta aberta & 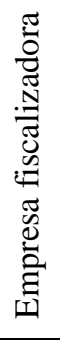 & $\stackrel{\stackrel{0}{0}}{\stackrel{0}{\Xi}}$ & 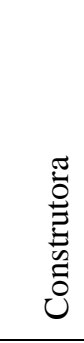 & 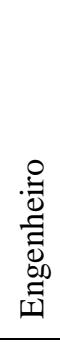 & 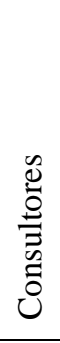 & 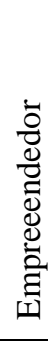 \\
\hline 1 & & & & & & & $\mathrm{X}$ & \\
\hline 2 & Aprox. $\mathrm{R} \$ 30 \mathrm{mil}$ & aprox. $\mathrm{R} \$ 200 / 250 \mathrm{mil}$ & & $\mathrm{X}$ & $\mathrm{X}$ & & & $X$ \\
\hline 3 & $\begin{array}{l}\text { Ainda não existe esse tipo } \\
\text { de pesquisas no Brasil. Os } \\
\text { resultados obtidos ainda } \\
\text { são pouco representativos } \\
\text { pois somente cerca de } 30 \\
\text { empreendimentos foram } \\
\text { certificados, de tipologias } \\
\text { diferentes (fábricas, } \\
\text { galpões, edifícios de } \\
\text { escritório, etc.). }\end{array}$ & & $\mathrm{X}$ & $\mathrm{X}$ & $\mathrm{X}$ & $\mathrm{X}$ & $X$ & $X$ \\
\hline 4 & $\begin{array}{l}\text { Não saberia informar, não } \\
\text { tive acesso a estes dados. }\end{array}$ & $\begin{array}{l}\text { Não saberia informar, não } \\
\text { tive acesso a estes dados. }\end{array}$ & & & & & & \\
\hline 5 & & Hoje, situa-se entre 5 e $10 \%$ & & & & & & \\
\hline 6 & Ainda em andamento & Em andamento & & & & & $\mathrm{X}$ & \\
\hline 7 & Aprox. 3\% & Aprox. $3 \%$ & & & & & & \\
\hline 8 & $\begin{array}{l}\text { Projeto: } 30 \% \\
\text { Consultoria: } 0 \% \text { - foi } \\
\text { incorporada ao projeto } \\
\text { Execução: } 0 \% \\
\text { Certificação: } 0,0003 \% \\
\text { Operações: }-14 \% \text { em } \\
\text { energia e }-25 \% \text { em água }\end{array}$ & $\begin{array}{l}\text { Como o hospital já planejava } \\
\text { investir em sistemas que } \\
\text { incorporassem economias na } \\
\text { operação: } 0 \%\end{array}$ & $X$ & $\mathrm{X}$ & & & & \\
\hline
\end{tabular}




\begin{tabular}{|c|c|c|c|c|c|c|c|c|}
\hline \multirow{2}{*}{$\begin{array}{l}\text { Número de } \\
\text { respondente }\end{array}$} & \multicolumn{7}{|c|}{$\begin{array}{l}\text { Quais das partes contratadas têm } \\
\text { profissionais com conhecimento sobre } \\
\text { certificação LEED? }\end{array}$} & \multirow[t]{2}{*}{$\begin{array}{l}\text { Qual a principal dificuldade com os projetistas, } \\
\text { empresa fiscalizadora, profissional credenciado } \\
\text { LEED, fornecedores, construtora,proprietario? }\end{array}$} \\
\hline & 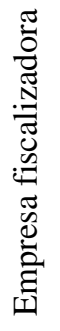 & 莺 & 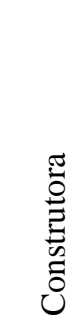 & 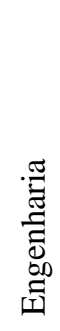 & 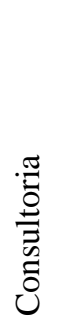 & 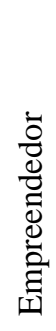 & 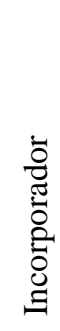 & \\
\hline 1 & & & & & $X$ & & & $\begin{array}{l}\text { A maior dificuldade é a compreensão do } \\
\text { processo de certificação, que tem como premissa } \\
\text { a mudança na forma convencional de se } \\
\text { desenvolver projetos e se construir. }\end{array}$ \\
\hline 2 & & $\mathrm{X}$ & $\mathrm{X}$ & $X$ & & $X$ & & $\begin{array}{l}\text { Por ser um projeto de cunho social, desde o } \\
\text { início todas as partes envolvidas tinham } \\
\text { consciência de importância - e do desafio - da } \\
\text { certificação }\end{array}$ \\
\hline 3 & X & & $\mathrm{X}$ & $\mathrm{X}$ & $\mathrm{X}$ & $X$ & $\mathrm{X}$ & $\begin{array}{l}\text { Os projetistas e consultores têm dificuldade de } \\
\text { alterar as suas metodologias de trabalho. A } \\
\text { certificação exige alguns documentos e cálculos } \\
\text { que normalmente não são elaborados em projetos } \\
\text { convencionais. }\end{array}$ \\
\hline 4 & & & & & & & & $\begin{array}{l}\text { Fazer com que as melhores coisas saiam do } \\
\text { papel, e que se leve as boas intenções até o fim. }\end{array}$ \\
\hline 5 & & & & $\mathrm{X}$ & $\mathrm{X}$ & & $\mathrm{X}$ & \\
\hline 6 & & & & & $X$ & & & Entender os requerimentos \\
\hline 7 & & $\mathrm{X}$ & $\mathrm{X}$ & $\mathrm{X}$ & X & $X$ & & $\begin{array}{l}\text { Justificar custos adicionais gerados pelo processo } \\
\text { e pelas especificações da certificação LEED }\end{array}$ \\
\hline 8 & $\mathrm{X}$ & $X$ & & & & & & $\begin{array}{l}\text { Educar os construtores, preenchimento da } \\
\text { documentação pela construtora, em inglês }\end{array}$ \\
\hline
\end{tabular}




\begin{tabular}{|c|c|c|c|c|c|c|c|c|c|}
\hline \multirow[t]{2}{*}{$\begin{array}{l}\text { Número de } \\
\text { respondente }\end{array}$} & \multicolumn{8}{|c|}{$\begin{array}{l}\text { Quem ficou responsável por orientar as } \\
\text { decisões, fornecer informaçôes sobre o processo } \\
\text { de certificaçã̃o, elaborar e organizar a } \\
\text { documentação exigida pelo USGBC? }\end{array}$} & \multirow[t]{2}{*}{$\begin{array}{l}\text { Quais são as maiores dificuldades em } \\
\text { relação à documentação exigida pela } \\
\text { certificaçãa LEED? projetos, } \\
\text { memoriais, contratos e relatórios? }\end{array}$} \\
\hline & 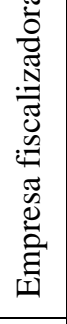 & 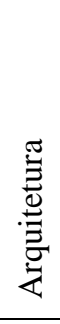 & 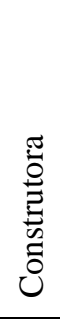 & 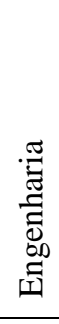 & 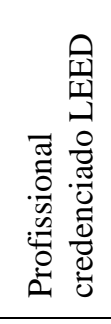 & 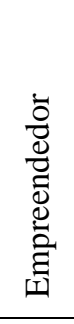 & 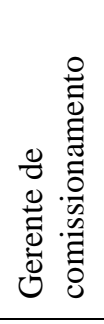 & 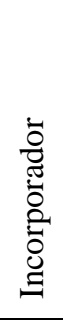 & \\
\hline 1 & & & & & $X$ & & & & $\begin{array}{l}\text { Uma delas é língua. Ter que traduzir } \\
\text { tudo é bem trabalhoso. Outra é } \\
\text { encontrar nos produtos brasileiros as } \\
\text { informações solicitadas pelo LEED. } \\
\text { Difícil também é ter a colaboração dos } \\
\text { projetistas e construtores nesta tarefa. }\end{array}$ \\
\hline 2 & & & & & $X$ & & & & $\begin{array}{l}\text { No nosso caso o prédio era bastante } \\
\text { fora do convencional e alguns itens, } \\
\text { bastante importantes sob o aspecto de } \\
\text { uma construção sustentável, } \\
\text { simplesmente não tinham como ser } \\
\text { avaliados. } \\
\text { ou seja, o desafio de conseguir o } \\
\text { "platina" não foi alcançado, embora o } \\
\text { empreendimento tenha muito mais } \\
\text { itens de construção sustentável do que } \\
\text { o formalmente solicitado. } \\
\text { e o requerimento especial encaminhado } \\
\text { solicitando estes serem levados em } \\
\text { consideração, foram rejeitados. } \\
\text { o Centro recebeu a menção honrosa da } \\
\text { Bienal Internacional de Arquitetura de } \\
\text { São Paulo - } \\
\text { www.institutojatobas.org.br }\end{array}$ \\
\hline 3 & & & & & $X$ & & & & $\begin{array}{l}\text { Cálculos e memoriais para } \\
\text { comprovação/evidências. }\end{array}$ \\
\hline 4 & & & & & $\mathrm{X}$ & & & & \\
\hline 5 & & & & & $\mathrm{X}$ & & & & \\
\hline 6 & & & & & $\mathbf{X}$ & & & & $\begin{array}{l}\text { Entender a documentação necessária e } \\
\text { em segundo lugar o volume de } \\
\text { tradução e conversão de unidades }\end{array}$ \\
\hline 7 & & & & & $\mathbf{X}$ & & & & $\begin{array}{l}\text { Gerar documentos que atendam as } \\
\text { especificações junto a fornecedores. } \\
\text { Por exemplo: declaração de \% de } \\
\text { reciclados pós-consumidor em relação } \\
\text { a alguns materiais utilizados na obra. }\end{array}$ \\
\hline 8 & & $\mathbf{X}$ & & & & & & & $\begin{array}{l}\text { Metodologia de apresentação dos } \\
\text { cálculos de renovação de ar, da } \\
\text { ASHRAE 62.1, para o hospital. }\end{array}$ \\
\hline
\end{tabular}




\begin{tabular}{|c|c|}
\hline $\begin{array}{l}\text { Número de } \\
\text { respondente }\end{array}$ & Indique a dificuldade mais difícil para obter a certificação? \\
\hline T & $\begin{array}{l}\text { Falta de comprometimento e empenho dos agentes (projetistas, construtora, etc) com a } \\
\text { certificação }\end{array}$ \\
\hline 2 & $\begin{array}{l}\text { Obter a documentação LEED necessária dos (fornecedores, projetistas, construtora, } \\
\text { consultores) }\end{array}$ \\
\hline 3 & $\begin{array}{l}\text { Pouca integração entre os agentes envolvidos no processo de projeto (cliente, arquiteto, } \\
\text { projetistas, construtora, consultores etc.) }\end{array}$ \\
\hline 4 & $\begin{array}{l}\text { Falta de fornecedores especializados para os insumos (materiais e tecnologias sustentáveis) } \\
\text { que o empreendimento demanda ou demandou }\end{array}$ \\
\hline 5 & Dificuldade em satisfazer os pré-requisitos do LEED \\
\hline 6 & $\begin{array}{l}\text { Falta de fornecedores especializados para os insumos (materiais e tecnologias sustentáveis) } \\
\text { que o empreendimento demanda ou demandou }\end{array}$ \\
\hline 7 & \\
\hline 8 & Mudanças do escopo do projeto \\
\hline
\end{tabular}

\begin{tabular}{|c|c|c|c|c|c|c|c|c|c|c|c|}
\hline \multirow{2}{*}{ 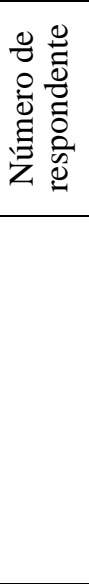 } & \multicolumn{5}{|c|}{$\begin{array}{l}\text { Como foi coordenada a } \\
\text { documentação LEED? }\end{array}$} & \multicolumn{6}{|c|}{$\begin{array}{l}\text { Quais as principais dificuldades encontradas ao longo do processo de } \\
\text { implementação da certificação LEED? }\end{array}$} \\
\hline & 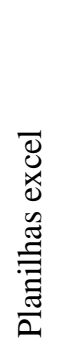 & $\begin{array}{l}\mathscr{U} \\
\stackrel{0}{\pi} \\
\sum_{0}^{3} \\
\dot{D}\end{array}$ & 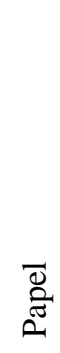 & 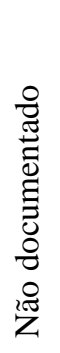 & $\stackrel{\mathscr{E}}{\tilde{0}}$ & 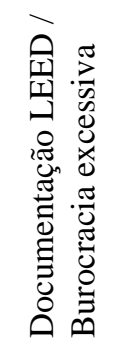 & 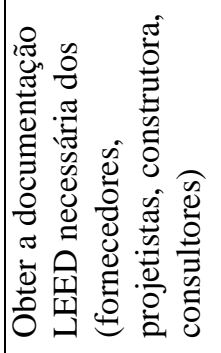 & 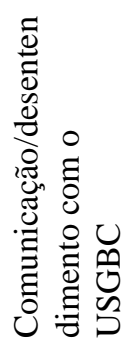 & 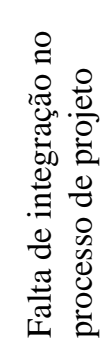 & 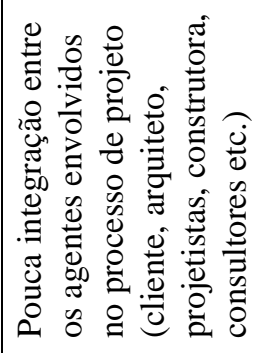 & 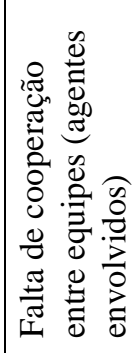 \\
\hline 1 & & $X$ & & & & D & MD & D & MD & MD & MD \\
\hline 2 & $X$ & $\mathrm{X}$ & $\mathrm{X}$ & & & D & D & D & $\mathrm{D}$ & D & D \\
\hline 3 & $\mathrm{X}$ & $\mathrm{X}$ & $\mathrm{X}$ & & & $\mathrm{RD}$ & $\mathrm{RD}$ & PD & $\mathrm{D}$ & D & D \\
\hline \multicolumn{12}{|l|}{4} \\
\hline 5 & & & & & & SD & PD & SD & SD & SD & SD \\
\hline 6 & $X$ & $X$ & & & $\begin{array}{l}\text { Processos } \\
\text { desenvolvidos } \\
\text { internamente } \\
\end{array}$ & $\mathrm{RD}$ & $\mathrm{RD}$ & SD & $\mathrm{D}$ & $\mathrm{D}$ & D \\
\hline 7 & $X$ & $X$ & $X$ & & & & & & & & \\
\hline 8 & & & & & LEED online & $\mathrm{RD}$ & MD & PD & MD & MD & MD \\
\hline
\end{tabular}




\begin{tabular}{|c|c|c|c|c|c|c|c|c|c|c|c|c|c|}
\hline \multirow{2}{*}{ 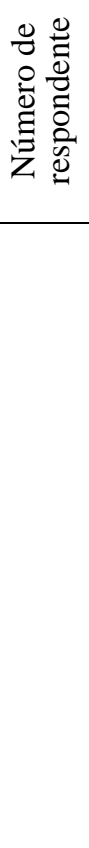 } & \multicolumn{13}{|c|}{$\begin{array}{l}\text { Quais as principais dificuldades encontradas ao longo do processo de implementação da certificação } \\
\text { LEED? }\end{array}$} \\
\hline & 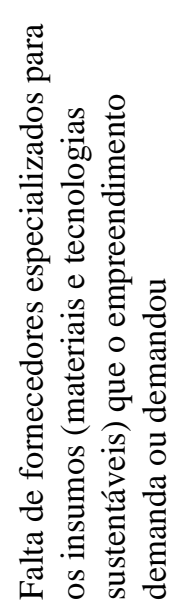 & 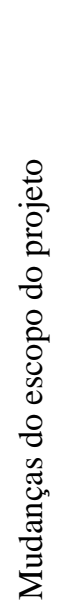 & 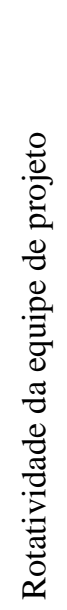 & 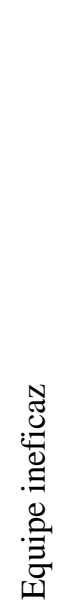 & 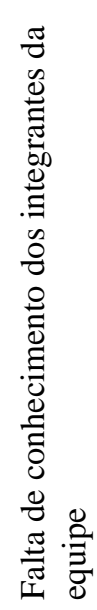 & 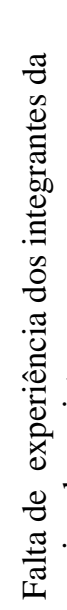 & 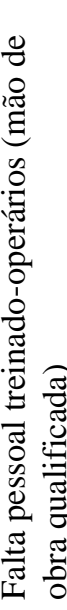 & ? & 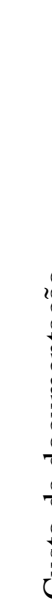 & 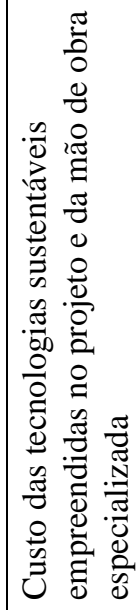 & 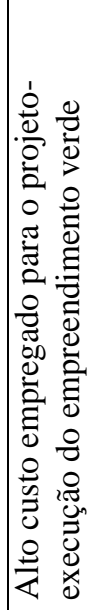 & 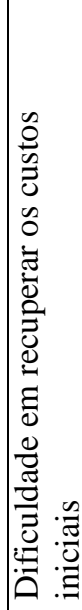 & 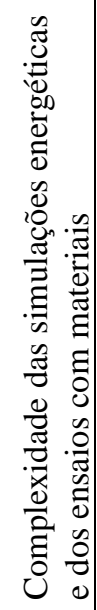 \\
\hline 1 & MD & D & $\mathrm{D}$ & MD & MD & $\mathrm{MD}$ & $\mathrm{MD}$ & $\mathrm{RL}$ & $\mathrm{RL}$ & D & $\mathrm{D}$ & $\mathrm{RD}$ & $\mathrm{D}$ \\
\hline 2 & MD & $\mathrm{RD}$ & $\mathrm{RD}$ & $\mathrm{D}$ & MD & $\mathrm{MD}$ & MD & $\mathrm{D}$ & $\mathrm{D}$ & $\mathrm{RD}$ & $\mathrm{RD}$ & SD & $\mathrm{D}$ \\
\hline 3 & PD & D & D & $\mathrm{RD}$ & $\mathrm{RD}$ & $\mathrm{RD}$ & PD & $\mathrm{PD}$ & $\mathrm{PD}$ & PD & PD & PD & $\mathrm{RD}$ \\
\hline 4 & MD & D & & & & $\mathrm{D}$ & & & & $\mathrm{D}$ & & & $\mathrm{D}$ \\
\hline 5 & SD & D & MD & MD & D & D & RD & $\mathrm{SD}$ & $\mathrm{SD}$ & PD & SD & SD & D \\
\hline 6 & MD & $\mathrm{RD}$ & $\mathrm{RD}$ & D & $\mathrm{RD}$ & $\mathrm{D}$ & D & $\mathrm{SD}$ & $\mathrm{PD}$ & RD & $\mathrm{RD}$ & PD & $\mathrm{RD}$ \\
\hline \multicolumn{14}{|l|}{1} \\
\hline 8 & D & MD & RD & RD & RD & RD & PD & $\mathrm{SD}$ & $\mathrm{RD}$ & PD & SD & SD & RD \\
\hline
\end{tabular}




\begin{tabular}{|c|c|c|c|c|c|c|c|c|c|c|}
\hline \multirow[t]{2}{*}{$\begin{array}{l}\text { Número de } \\
\text { respondente }\end{array}$} & \multicolumn{10}{|c|}{$\begin{array}{l}\text { Quais as principais dificuldades encontradas ao longo do processo de implementação da } \\
\text { certificaçãa LEED? }\end{array}$} \\
\hline & 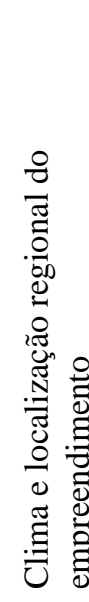 & 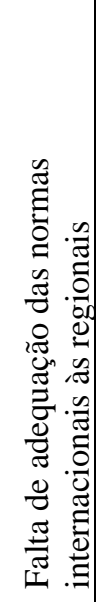 & 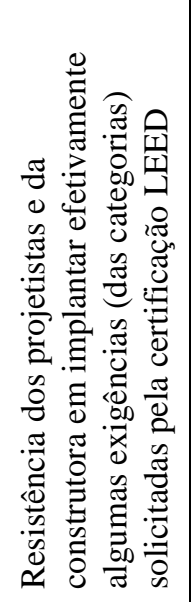 & 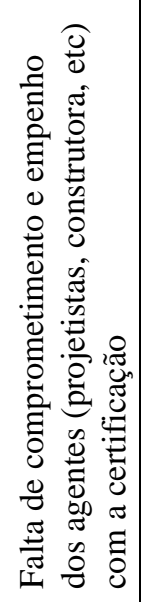 & 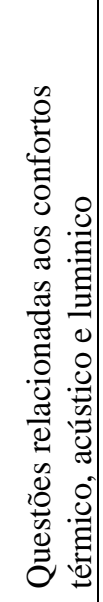 & 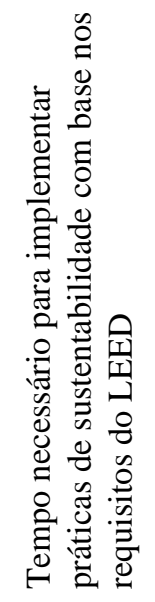 & 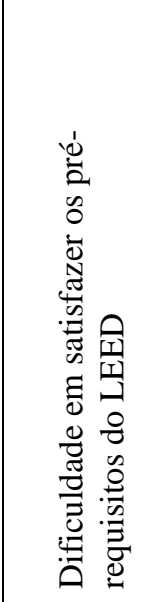 & 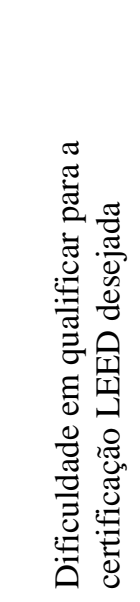 & 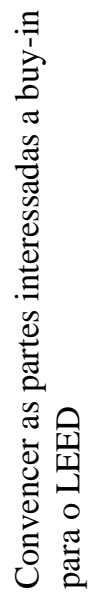 & 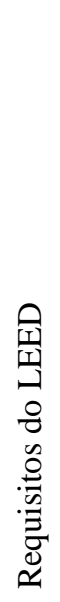 \\
\hline 1 & $\mathrm{RD}$ & $\mathrm{D}$ & MD & MD & D & D & D & D & MD & $\mathrm{RD}$ \\
\hline 2 & D & $\mathrm{D}$ & $\mathrm{D}$ & D & D & D & D & D & D & $\mathrm{D}$ \\
\hline 3 & PD & $\mathrm{PD}$ & $\mathrm{RD}$ & $\mathrm{RD}$ & PD & $\mathrm{PD}$ & PD & PD & $\mathrm{PD}$ & $\mathrm{PD}$ \\
\hline 4 & & & & & & $\mathrm{D}$ & & & & \\
\hline 5 & SD & SD & SD & SD & SD & & $\mathrm{MD}$ & $\mathrm{D}$ & $\mathrm{D}$ & SD \\
\hline 6 & $\mathrm{PD}$ & $\mathrm{RD}$ & $\mathrm{RD}$ & D & $\mathrm{SD}$ & PD & PD & PD & $\mathrm{RD}$ & $\mathrm{PD}$ \\
\hline \multicolumn{11}{|l|}{7} \\
\hline 8 & SD & MD & SD & D & SD & SD & $\mathrm{RD}$ & SD & SD & PD \\
\hline
\end{tabular}

\begin{tabular}{|c|c|}
\hline 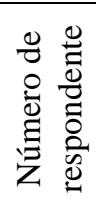 & $\begin{array}{l}\text { Pôde, mencionar outras dificuldades encontradas durante o processo de implementação da } \\
\text { certificação LEED }\end{array}$ \\
\hline & Resposta aberta \\
\hline 1 & \\
\hline 2 & Mencionado nas anteriores \\
\hline 3 & \\
\hline 4 & \\
\hline 5 & \\
\hline 6 & $\begin{array}{l}\text { A documentação é realmente uma novidade para muitos. Uma mudança drástica no processo de } \\
\text { uma empresa de construção e projetistas. }\end{array}$ \\
\hline 7 & $\begin{array}{l}\text { Nenhuma dificuldade que vá além da adequação dos agentes envolvidos no processo em gerar de } \\
\text { forma eficiente as informações necessárias ao processo de certificação. Considero a metodologia } \\
\text { LEED }\end{array}$ \\
\hline 8 & \\
\hline
\end{tabular}




\begin{tabular}{|c|c|}
\hline 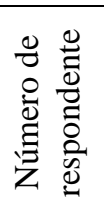 & Quais são os entraves ou barreiras internas e externas para a implementação da certificação LEED? \\
\hline & Resposta aberta \\
\hline 1 & \\
\hline 2 & $\begin{array}{l}\text { Precisa ter muita disposição e boa vontade. pois além de todas as complexidades inerente a } \\
\text { qualquer obra (mão de obra de baixa qualificação, inclusive dos engenheiros, estouro de custos, } \\
\text { estouro de prazos), a certificaçãa é outra "camisa de força".Acho que o LEED no Brasil deveria ter } \\
\text { um capitulo, importante, relativo a planejamento e gestão, tratando inclusive da relação } \\
\text { fornecedores x contratante (que é cada vez mais insustentável) - estamos tratando sempre de } \\
\text { máquinas, processos, materiais e cada vez menos das PESSOAS }\end{array}$ \\
\hline 3 & \\
\hline 4 & \\
\hline 5 & \\
\hline 6 & $\begin{array}{l}\text { As varias mencionadas acima, mas tudo contornável com determinação da gerencia, vontade da } \\
\text { equipe, treinamento e adequação aos requerimentos do LEED. }\end{array}$ \\
\hline 7 & $\begin{array}{l}\text { Vender a ideia de custos maiores inicialmente para gerar maior eficiência durante a vida útil do } \\
\text { empreendimento em uma cultura imediatista e de alta taxa de juros como a Brasileira. }\end{array}$ \\
\hline 8 & $\begin{array}{l}\text { Tornar a certificação LEED objeto de trabalho de consultoria especializada. O LEED foi } \\
\text { idealizado para ser implantado pelos agentes já presentes dos projetos e construção dos edifícios. }\end{array}$ \\
\hline
\end{tabular}

\begin{tabular}{|c|c|}
\hline 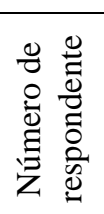 & $\begin{array}{l}\text { Como poderia ter sido implantada a certificação LEED de maneira mais eficaz antes e durante a } \\
\text { construção? }\end{array}$ \\
\hline & Resposta aberta \\
\hline 1 & \\
\hline 2 & Resposta nas anteriores e acima \\
\hline 3 & \\
\hline 4 & $\begin{array}{l}\text { Se a empresa tivesse interesse em certificar, e iniciasse o processo desde a concepção do projeto, a } \\
\text { implementação da metodologia com certeza seria mais fácil. } \\
\text { A empresa construtora teve de reciclar alguns procedimentos (como o gerenciamento de resíduos } \\
\text { no canteiro), o que foi um processo mais complicado do que precisaria ser...se todos os envolvidos } \\
\text { previssem desde a contratação que a obra seria certificada, o comprometimento seria maior. }\end{array}$ \\
\hline 5 & \\
\hline 6 & Começar mais cedo, o quanto antes, inclusive na escolha do terreno \\
\hline 7 & $\begin{array}{l}\text { Prioridade por parte do grupo investidor na certificação como parte do programa na concepção do } \\
\text { projeto. Planejamento desde a concepção do projeto com foco claro na certificação a ser atingida. }\end{array}$ \\
\hline 8 & $\begin{array}{l}\text { Tornar o sistema acessível (português, SI, normatização local) para incorporação da técnica pelos } \\
\text { escritórios de projeto e construtoras }\end{array}$ \\
\hline
\end{tabular}




\begin{tabular}{|c|c|c|c|c|c|c|}
\hline \multirow{2}{*}{ 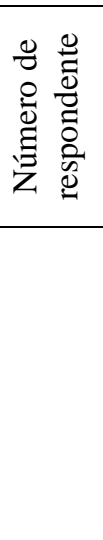 } & \multicolumn{6}{|c|}{ Na sua opinião, como poderia ser melhorado o processo de certificação? } \\
\hline & 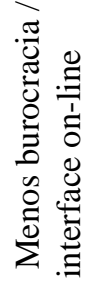 & 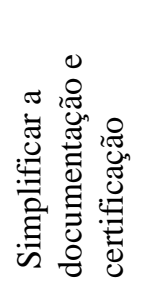 & 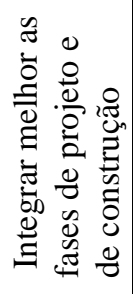 & 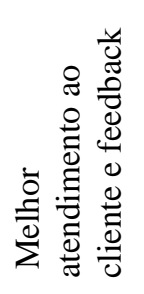 & 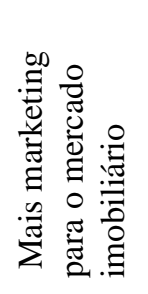 & $\frac{\tilde{E}}{\tilde{E}}$ \\
\hline 1 & & & $\mathrm{X}$ & & & \\
\hline 2 & $X$ & X & $X$ & & & \\
\hline 3 & & & & & & $\begin{array}{l}\text { Melhor capacitação dos envolvidos e } \\
\text { consequentemente, melhor percepção da } \\
\text { necessidade do trabalho integrado entre as } \\
\text { partes }\end{array}$ \\
\hline 4 & & & & & & $\begin{array}{l}\text { Como não fomos até o final, não saberia } \\
\text { informar }\end{array}$ \\
\hline 5 & & & & & & \\
\hline 6 & $\mathrm{X}$ & $\mathrm{X}$ & $\mathrm{X}$ & $\mathrm{X}$ & $\mathrm{X}$ & Melhor treinamento \\
\hline 7 & & & & & & $\begin{array}{l}\text { Utilização de profissionais qualificados de } \\
\text { forma a facilitar o processo }\end{array}$ \\
\hline 8 & & & & & & Nacionalização \\
\hline
\end{tabular}

\begin{tabular}{|c|c|c|c|c|c|c|c|c|c|}
\hline \multirow{2}{*}{ 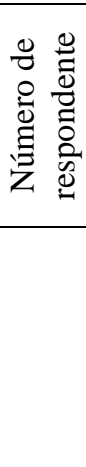 } & \multicolumn{3}{|c|}{$\begin{array}{l}\text { Em que medida a certificação LEED } \\
\text { afetou o processo de projeto, } \\
\text { execução e produto final (edifício)? }\end{array}$} & \multicolumn{6}{|c|}{$\begin{array}{l}\text { Na tabela a seguir indique: } \mathrm{O} \text { grau de importância de cada uma } \\
\text { das categorias consideradas no projeto }\end{array}$} \\
\hline & $\frac{\stackrel{0}{0}}{\frac{0}{2}}$ & 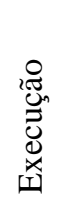 & 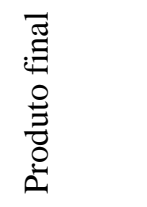 & 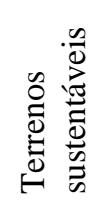 & 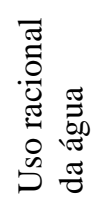 & 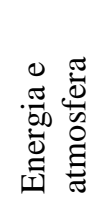 & 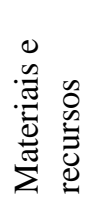 & 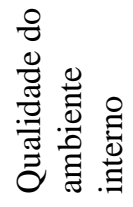 & 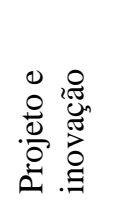 \\
\hline 1 & MM & & & RI & & & & & RI \\
\hline 2 & & & & & MI & & & MI & MI \\
\hline 3 & & & & & & & & & RI \\
\hline 4 & & $S$ & & RI & MI & MI & & & \\
\hline 5 & & & & & & & & & \\
\hline 6 & MM & MM & MM & RI & & MI & RI & & MI \\
\hline 7 & MM & $S$ & MM & MI & MI & MI & MI & MI & MI \\
\hline 8 & MM & & MM & MI & & MI & MI & MI & \\
\hline
\end{tabular}




\begin{tabular}{|c|c|c|c|c|c|c|c|c|c|c|c|c|}
\hline \multirow{2}{*}{ 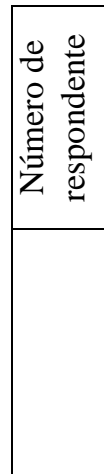 } & \multicolumn{6}{|c|}{$\begin{array}{l}\mathrm{Na} \text { tabela a seguir indique: } \mathrm{O} \text { grau de dificuldade em } \\
\text { atingir as categorias exigidas pela certificação LEED. }\end{array}$} & \multicolumn{6}{|c|}{$\begin{array}{l}\text { Na tabela a seguir indique: As categorias que } \\
\text { demandaram maior cuidado durante o projeto e } \\
\text { a obra }\end{array}$} \\
\hline & 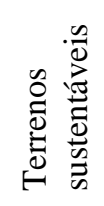 & 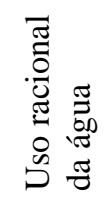 & 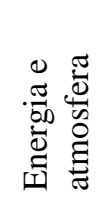 & 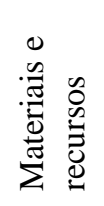 & 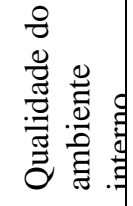 & 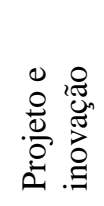 & 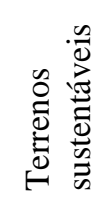 & 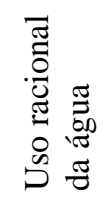 & 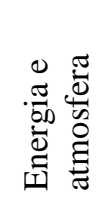 & 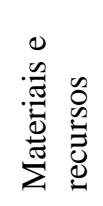 & 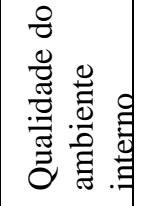 & 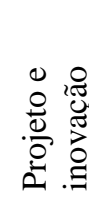 \\
\hline 1 & ID & & & & & ID & ID & & & & & ID \\
\hline 2 & & & & & & & ID & ID & ID & ID & ID & ID \\
\hline 3 & & ID & & & ID & & & ID & & ID & & \\
\hline 4 & ID & & & MD & & $\mathrm{MF}$ & ID & ID & & MA & MA & NA \\
\hline 5 & & & & & & & & & & & & \\
\hline 6 & MF & MF & & MD & ID & & NA & NA & & & MA & \\
\hline 7 & $\mathrm{MF}$ & & ID & & MF & $\mathrm{MF}$ & ID & ID & ID & ID & ID & ID \\
\hline 8 & ID & ID & & & & MF & ID & & MA & & MA & \\
\hline
\end{tabular}

